\title{
DIÓXIDO DE CARBONO VIA FERTIRRIGAÇÃO EM BATATEIRA ( Solanum tuberosum L.) SOB CONDIÇÕES DE CAMPO
}

\section{WALTER GeREMIAS RODRIGUEZ RoBLES}

\author{
Tese apresentada à Escola Superior de \\ Agricultura "Luiz de Queiroz", Universidade de \\ São Paulo, para obtenção do título de Doutor \\ em Agronomia, Área de Concentração: \\ Irrigação e Drenagem.
}

$P I R A C I C A B A$

Estado de São Paulo - Brasil

Agosto - 2003 


\title{
DIÓXIDO DE CARBONO VIA FERTIRRIGAÇÃO EM BATATEIRA (Solanum tuberosum L.) SOB CONDIÇÕES DE CAMPO
}

\section{WALTER GEREMIAS RODRIGUEZ ROBLES}

Engenheiro Agrônomo

Orientador: Prof. Dr. TARLEI ARRIEL BOTREL

\author{
Tese apresentada à Escola Superior de \\ Agricultura "Luiz de Queiroz", Universidade de \\ São Paulo, para obtenção do título de Doutor \\ em Agronomia, Área de Concentração: \\ Irrigação e Drenagem.
}

PIRACICABA

Estado de São Paulo - Brasil

Agosto - 2003 


\section{Dados Internacionais de Catalogação na Publicação (CIP)} DIVISÃO DE BIBLIOTECA E DOCUMENTAÇÃO - ESALQ/USP

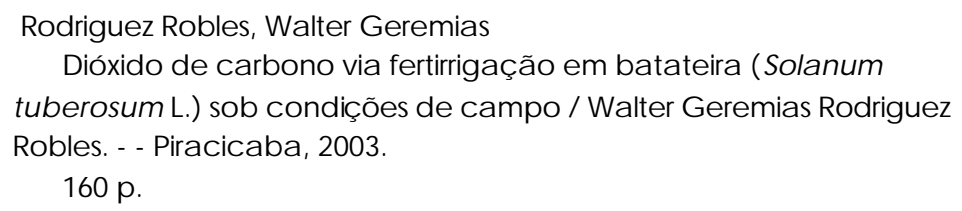

Tese (doutorado) - Escola Superior de Agricultura Luiz de Queiroz, 2003. Bibliografia.

1. Batata 2. Gásc arbônico 3. Imigação porgoteja mento 4. Produção vegetal 5. Qualidade da produção 6. TubérculosI. Título

CDD 633.491

\section{"Permitida a cópia total ou parcial deste documento, desde que citada a fonte - $O$ autor"}


Aos meus pais: Dimas e Santa,

Irmãos: Román, Feliciano (em memória),

Aída, Beltran e Elisabeth,

pelo carinho, compreensão e incentivo.

\section{Ofereço}

A minha esposa Patrícia Anchorena e minha

filha Natalia, pelo amor e compreensão.

Dedico 


\section{AGRADECIMENTOS}

A Deus, pela fé e força concedida em todos os momentos.

À Escola Superior de Agricultura "Luiz de Queiroz", por abrir suas portas para me receber.

Ao Departamento de Engenharia Rural, pela oportunidade concedida para realização deste curso.

Ao Prof. Dr. Tarlei Arriel Botrel, pela orientação, apoio e amizade durante a permanência no curso.

À Fundação de Amparo à Pesquisa do Estado de São Paulo (FAPESP), pela concessão da bolsa de estudos.

Ao Prof. Dr. Ricardo Ferraz de Oliveira pelo apoio na pesquisa e ter facilitado o laboratório do Depto. de Ciências Biológicas.

À Professora Dra. Silene Bruder Silveira Sarmento pela colaboração na análise das características tecnológicas permitindo o uso do laboratório do Depto. de Agroindústria, Alimentos e Nutrição - seção de amido e féculas. Assim também à funcionária Carlota.

Ao Prof. Dr. Edwin Marcos Moises Ortega do Depto. Ciências Exatas, pela contribuição na realização da análise estatística.

Ao Prof. Dr. Sergio Nascimento Duarte e ao colega Denis Cesar Cararo pela colaboração na correção do trabalho.

Aos professores do Depto. de Engenharia Rural pelo ensinamento durante 0 curso. 
Ao Prof. Dr. Newton do Prado Granja, pesquisador do IAC - Seção Tubérculos e Raízes, pela suas sugestões e pelo fornecimento da batata-semente do cultivar Itararé.

Ao Prof. Dr. Paulo César Tavares de Melo do Depto. de Produção Vegetat ESALQ/USP, pela suas sugestões no decorrer da pesquisa.

Ao Eng ${ }^{\circ}$ Natalino Shimoyama, Gerente Geral da Associação Brasileira da Batata (ABBA) pelo fornecimento da batata-semente dos cultivares Atlantic, Jatte-Bintje e Monalisa.

Aos funcionários do Depto. de Engenharia Rural, pelo apoio e colaboração durante o desenvolvimento do trabalho.

Aos colegas de Irrigação e Drenagem pela convivência durante a permanência no curso.

Aos Funcionários da Biblioteca Central da ESALQ/USP, pelo apoio e colaboração com o material bibliográfico.

Enfim, a todos que direta ou indiretamente colaboraram para que este material fosse realizado. 


\section{SUMÁRIO}

Página

RESUMO......................................................................

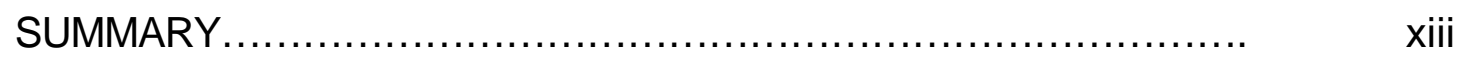

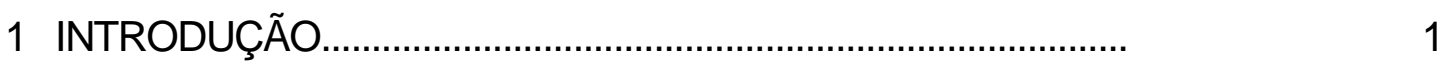

2 REVISÃO DE LITERATURA..................................................... 3

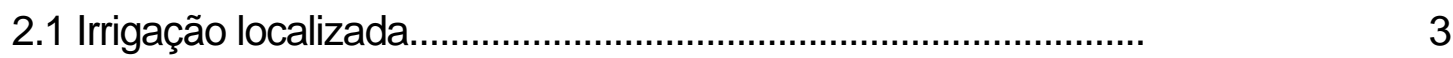

2.1.1 Características de irrigação por gotejamento.............................. 5

2.1.2 Respostas das plantas ao sistema de irrigação por gotejamento.....................................................................

2.2 Considerações gerais sobre a batateira...................................... 7

2.2.1 Descrição das variedades estudadas....................................... 8

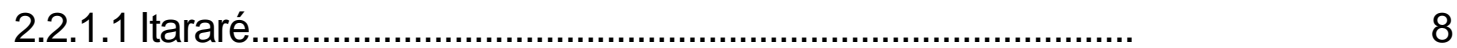

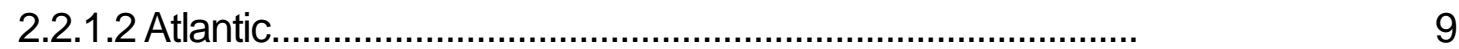

2.2.1.3 Jatte-Bintje ................................................................... 9

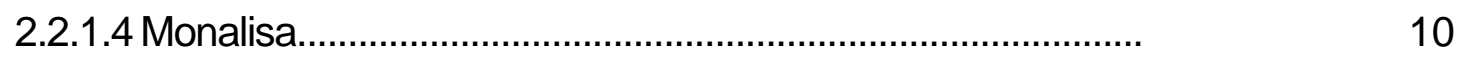

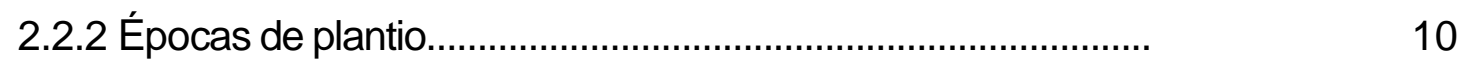

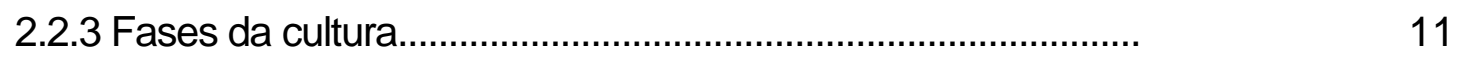

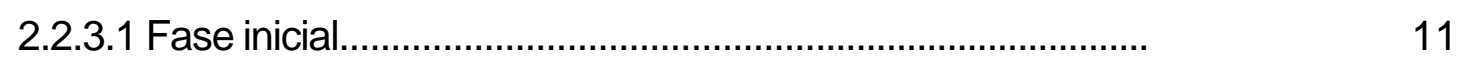

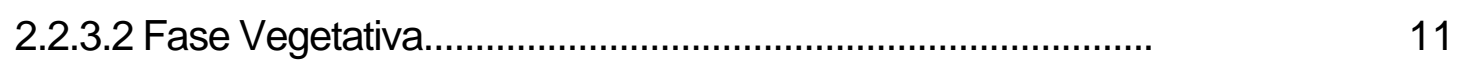

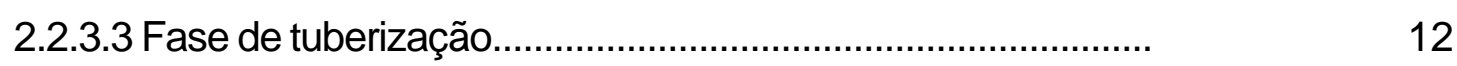

2.2.3.4 Fase de senescência........................................................... 


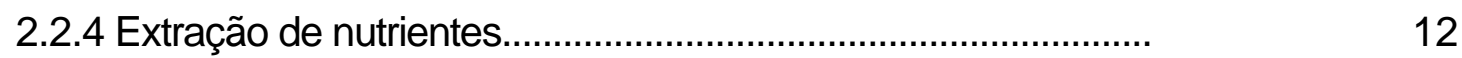

2.2.5 Período de exigência e acúmulo de nutrientes.............................. 13

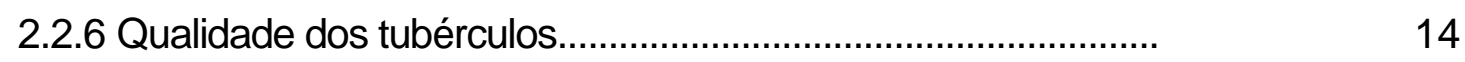

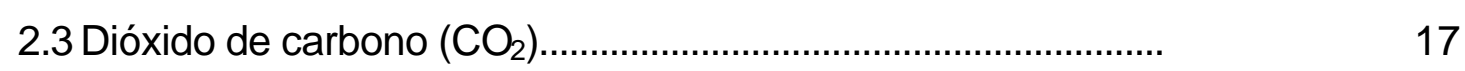

2.4 Metabolismo fotossintético na batateira......................................... 19

2.5 Efeitos de $\mathrm{CO}_{2}$ no solo e na planta............................................... 23

2.6 Dióxido de carbono e efeitos evolutivos......................................... 28

3 MATERIAL E MÉTODOS.............................................................

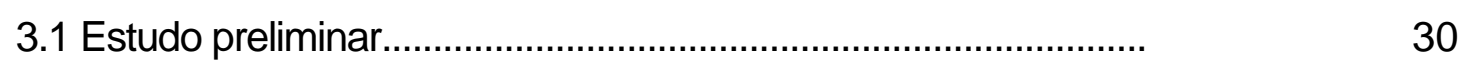

3.1.1 Ponto de saturação de luz e ponto de compensação de $\mathrm{CO}_{2} \ldots . \quad 30$

3.1.2 Principio de funcionamento do aparelho IRGA......................... $\quad 30$

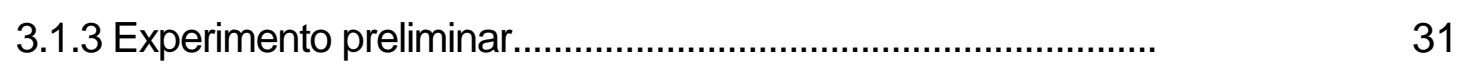

3.2 Caracterização da área experimental a campo............................. 33

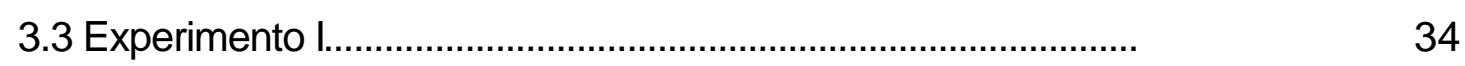

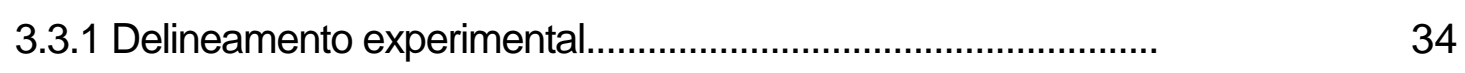

3.3.2 Caracterização Física e Química do Solo.................................. $\quad 35$

3.3.3 Preparo do solo e plantio....................................................... 36

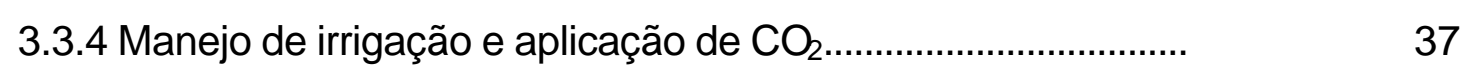

3.3.5 Uniformidade de irrigação....................................................... 42

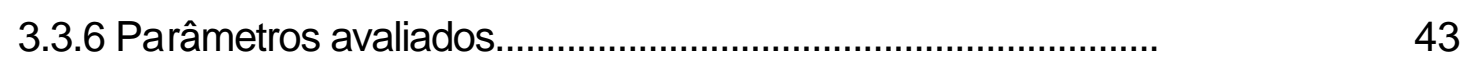

3.3.7 Amostragem de parte aérea, raízes e tubérculos....................... $\quad 46$

3.3.8 Produtividade total de tubérculos.............................................. 46

3.3.9 Produtividade comercial de tubérculos...................................... 47

3.3.10 Teor de sólidos solúveis totais.................................................

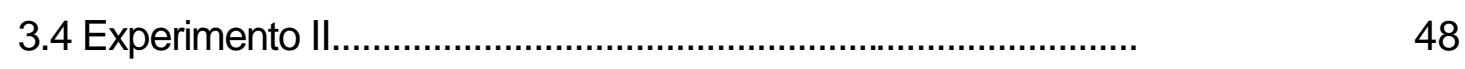

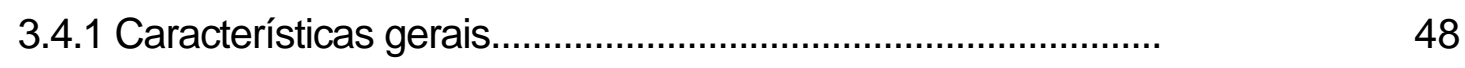

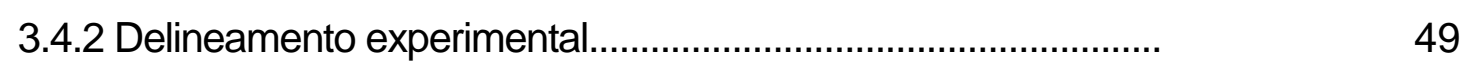

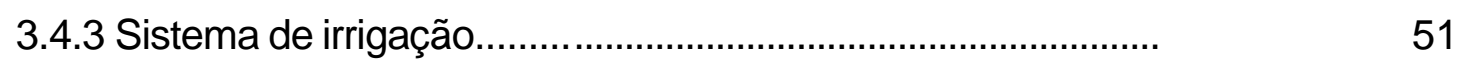

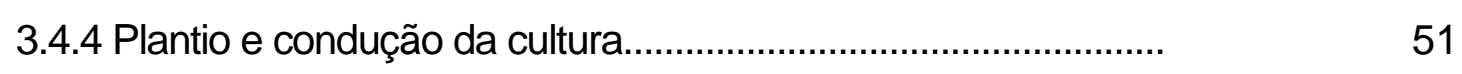

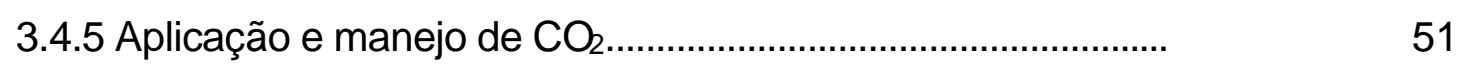


3.4.6 Medição de $\mathrm{pH}$ no solo.

3.4.7 Parâmetros avaliados.

3.4.8 Amostragem de parte aérea, raízes e tubérculos.

3.4.9 Produtividade total de tubérculos.

3.4.10 Produtividade comercial de tubérculos.

3.4.11 Características tecnológicas dos tubérculos.

3.4.11.1 $\mathrm{pH}$.

3.4.11.2 Acidez titulável.

3.4.11.3 Firmeza

3.4.11.4 Sólidos solúveis totais

3.4.11.5 Coloração da polpa.

3.4.11.6 Teor de matéria seca..

3.4.11.7 Teor de açúcares redutores..

3.4.11.8 Teor de amido.

4 RESULTADOS E DISCUSSÃO.

4.1 Estudo preliminar...

4.1.1 Ponto de saturação de luz e ponto de compensação de $\mathrm{CO}_{2} \ldots$.

4.2 Experimento I..

4.2.1 Elementos meteorológicos..

4.2.2 Uniformidade de irrigação..

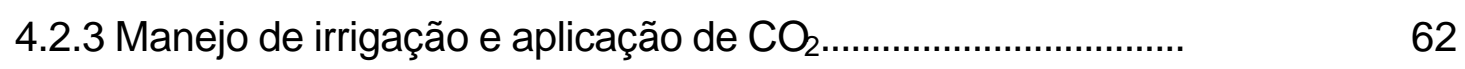

4.2.3.1 Irrigação

4.2.3.2 Aplicação de $\mathrm{CO}_{2}$.

4.2.4 Acúmulo de nutrientes na parte aérea, raízes e tubérculos.

4.2.5 Análise de Crescimento.

4.2.5.1 Número de folhas.

4.2.5.2 Número de estolões.

4.2.5.3 Número de tubérculos..

4.2.5.4 Área foliar. 75

4.2.5.5 Massa seca da parte da parte aérea. 


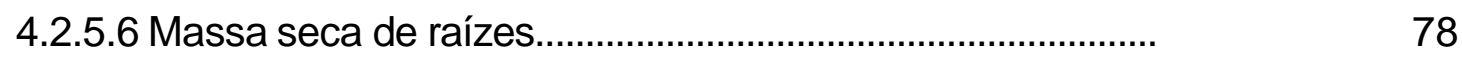

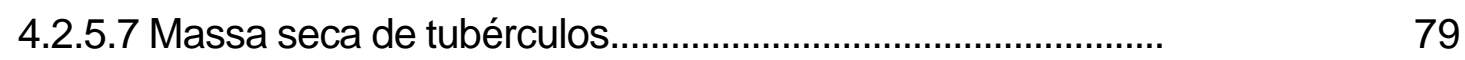

4.2.5.8 Índice de área foliar..............................................................

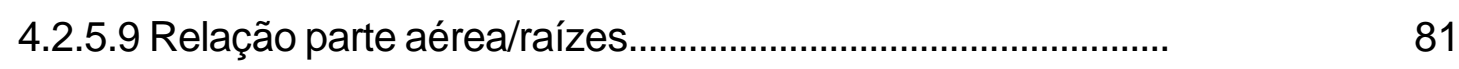

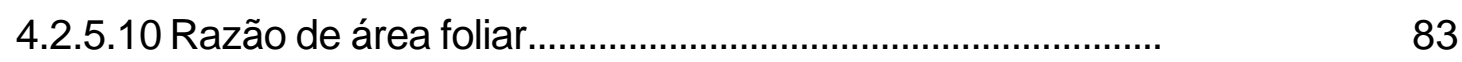

4.2.5.11 Produtividade total de tubérculos................................................. 86

4.2.5.12 Classificação comercial de batata.........................................

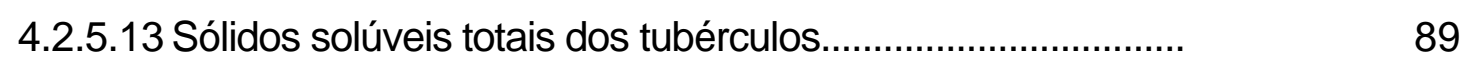

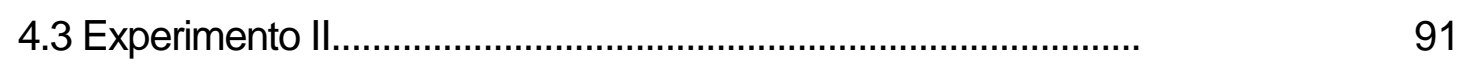

4.3.1 Elementos meteorológicos..................................................... 91

4.3.2 Uniformidade de irrigação...........................................................

4.3.3 Manejo de irrigação e aplicação de $\mathrm{CO}_{2}$.................................... 93

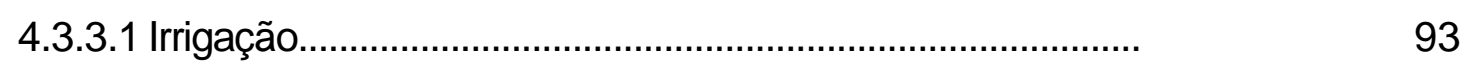

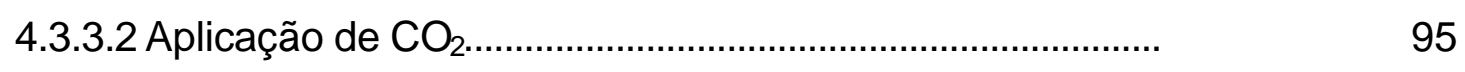

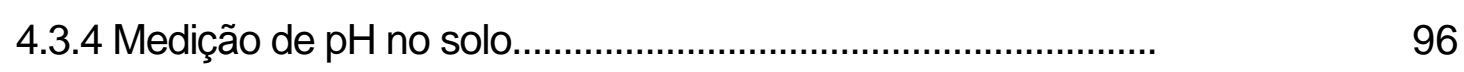

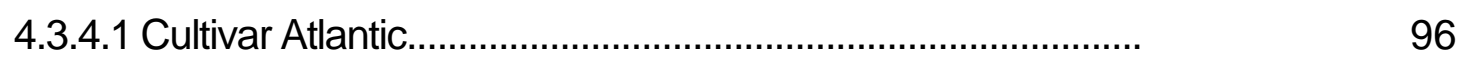

4.3.4.2 Cultivar Jatte-Bintje............................................................

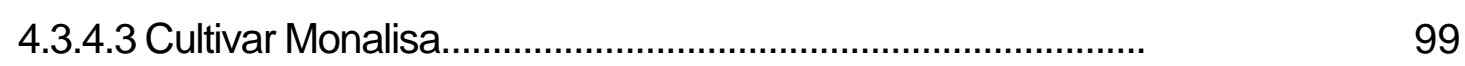

4.3.5 Acúmulo de nutrientes na parte aérea, raízes e tubérculos....... 100

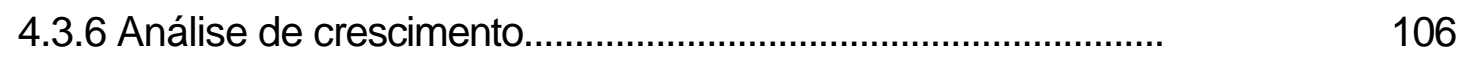

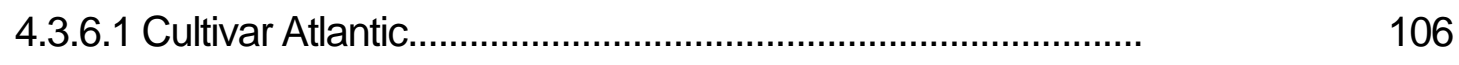

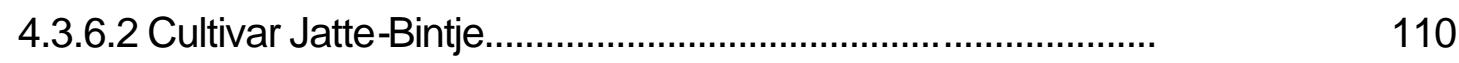

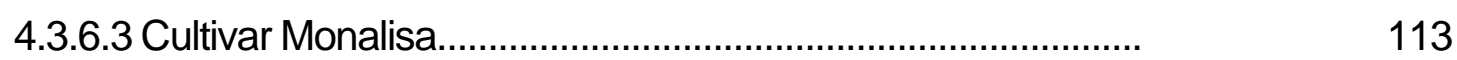

4.3.7 Análise de variância e comparações múltiplas da produtividade das três cultivares referente às dosagens de

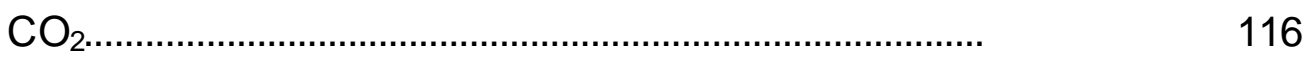

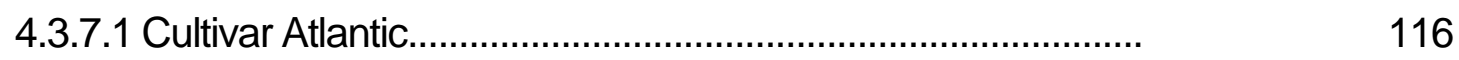

4.3.7.2 Cultivar Jatte-Bintje.................................................................

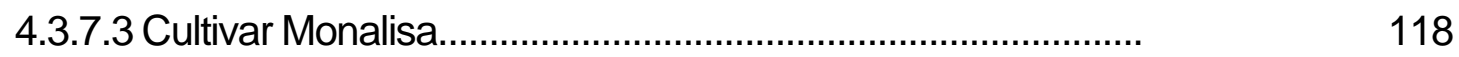

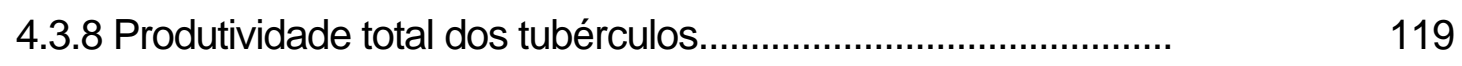


4.3.9 Classificação comercial de batata dos três cultivares referente

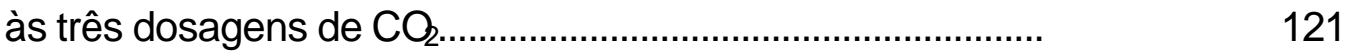

4.3.10 Características tecnológicas dos tubérculos............................ 122

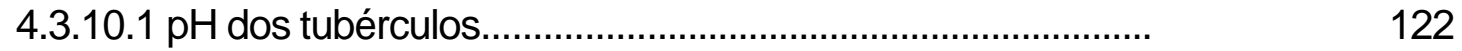

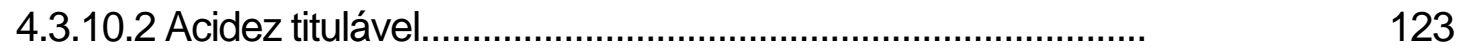

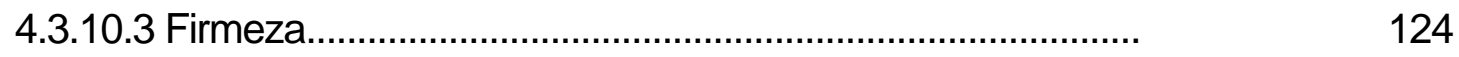

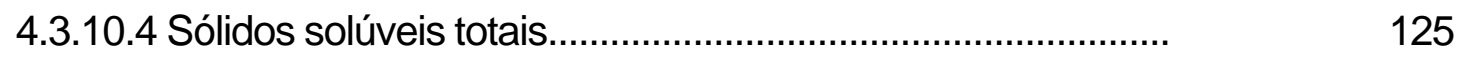

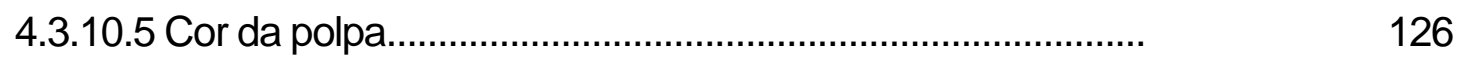

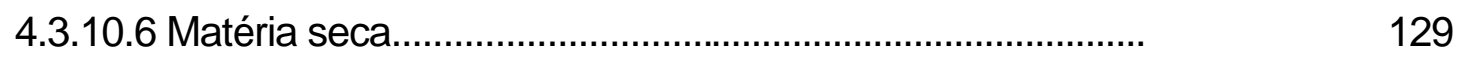

4.3.10.7 Açúcares redutores........................................................ 130

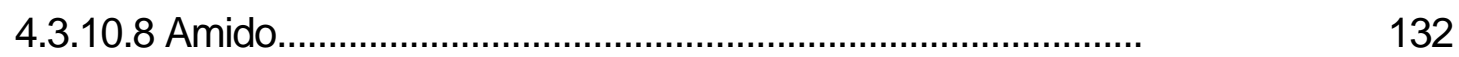

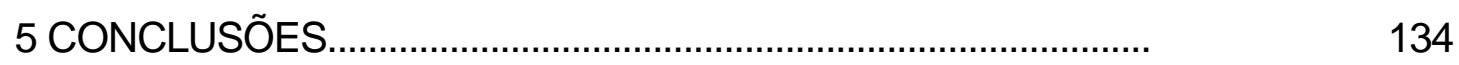

REFERÊNCIAS BIBLIOGRÁFICAS.............................................. 136

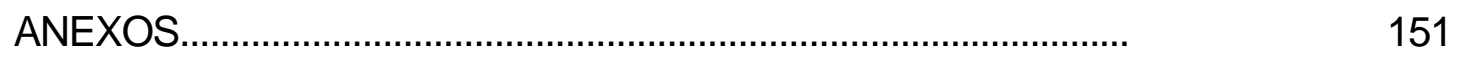




\title{
DIÓXIDO DE CARBONO VIA FERTIRRIGAÇÃO EM BATATEIRA \\ (Solanum tuberosum L.) SOB CONDIÇÕES DE CAMPO
}

\author{
Autor: WALTER GEREMIAS RODRIGUEZ ROBLES \\ Orientador: Prof. Dr. TARLEI ARRIEL BOTREL
}

\section{RESUMO}

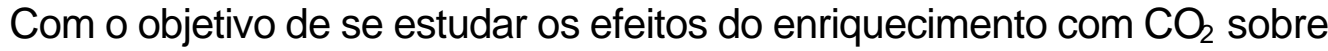
as características fisiológicas da cultura da batateira e a sua influência na produtividade e qualidade dos tubérculos, foi conduzida a pesquisa em condições de campo na área experimental da Fazenda Areão pertencente ao Departamento de Engenharia Rural da Escola Superior de Agricultura "Luiz de Queiroz" - USP, localizado no município de Piracicaba - São Paulo. Foram conduzidos dois experimentos. No primeiro, trabalhou-se com o cultivar Itararé e as concentrações de $\mathrm{CO}_{2}$ foram: $\mathrm{T} 1=0$ (sem aplicação de $\infty_{2}$ ); $\mathrm{T} 2=205,20$; $\mathrm{T} 3=279,36$; $\mathrm{T} 4=$ 353,52; e T5= 427,68 $\mathrm{Kg} \mathrm{ha}^{-1}$ de $\mathrm{CO}_{2}$. Os parâmetros avaliados foram: número de folhas (NF), número de estolões (NE), área foliar ( $\mathrm{AF}$ ), índice de área foliar (IAF), número de tubérculos (NT), massa seca da parte aérea (MSPA), massa seca de raízes (MSR), massa seca de tubérculos (MST), relação parte aérea/raízes, produção de batata, teor de matéria seca 
(TMS) e teor de sólidos solúveis totais (TSST). O delineamento estatístico para os parâmetros avaliados durante o desenvolvimento fisiológico foi de parcelas subdivididas no tempo; o delineamento utilizado para análise da produção foi de blocos ao acaso. Já no experimento II, trabalhou-se com os cultivares Atlantic, Jatte-Bintje e Monalisa e as concentrações de $\mathrm{CO}_{2}$ foram: T1=0, T2=145,36 e T3=290,72 $\mathrm{kg} \mathrm{ha}^{-1}$. Os parâmetros avaliados foram os mesmos que no experimento I e também: $\mathrm{pH}$ do solo, $\mathrm{pH}$ da polpa, acidez titulável (AT), firmeza da polpa (FP), TSST, cor da polpa (CP), TMS, teor de açúcares redutores (TAR) e amido dos tubérculos. O delineamento estatístico para os parâmetros avaliados durante o desenvolvimento fisiológico foi o de análise de regressão múltipla, enquanto o delineamento utilizado para análise da produção, pH da polpa, AT, FP, TSST, CP, TMS, AR e amido foi de blocos ao acaso, com arranjo fatorial $3 \mathrm{x}$ 3. Do experimento I conclui-se que o cultivar Itararé não apresentou variação de produtividade total com o aumento das doses de $\mathrm{CO}_{2}$; mais de $50 \%$ da produção comercial do cultivar Itararé foi classificada como classe especial independente das doses de $\mathrm{CO}_{2}$; o TSST nos tubérculos do cultivar Itararé decresceram com o aumento das doses de $\mathrm{CO}_{2}$. Do experimento II conclui-se que a produtividade total de batata dos cultivares Atlantic, Jatte-Bintje e Monalisa diminuiu com doses crescentes de $\mathrm{CO}_{2}$; o cultivar Monalisa apresentou maior produtividade do que os cultivares Jatte-Bintje e Atlantic, respectivamente, independente das doses de $\mathrm{CO}_{2}$; a aplicação de $\mathrm{CO}_{2}$ nos cultivares Atlantic, Jatte-Bintje e Monalisa não alterou significativamente a acidez, o TSST e o TMS dos tubérculos. Entretanto, os tubérculos dos cultivares Monalisa e Atlantic perderam firmeza, e o cv. JatteBintje não sofreu impacto do tratamento. Os cultivares Atlantic e Jatte-Bintje apresentaram variação do teor de amido com a aplicação de $\mathrm{CO}_{2}$. Além disso, houve aumento de TAR no cultivar Jatte-Bintje com a aplicação do tratamento. 


\title{
CARBON DIOXIDE THROUGH IRRIGATION IN POTATOES (Solanum tuberosum L.) UNDER FIELD CONDITIONS
}

\author{
Author: WALTER GEREMIAS RODRIGUEZ ROBLES \\ Adviser: Prof. Dr. TARLEI ARRIEL BOTREL
}

\section{SUMMARY}

With the objective to study the effects with $\mathrm{CO}_{2}$ enrichment on the physiological characteristics of potatoes and its influence in the productivity and quality of the tubers, this research was carried out in field conditions at the experimental area "Fazenda Areão" of the Department of Rural Engineering of the "Escola Superior de Agricultura Luiz de Queiroz - Universidade de São Paulo", in Piracicaba, São Paulo State, Brazil. Two experiments was carried out. In the experiment 1 with cultivar Itarare the $\mathrm{CO}_{2}$ levels were: $\mathrm{T} 1=0$ (without application of $\mathrm{CO}_{2}$ ) T2 = 205,20; T3 = 279,36; T4 = 353,52; and T5 = 427,68 $\mathrm{kg} \mathrm{ha}^{-1}$. The appraised parameters were: leaves number, stolons number, area foliate, index of the area foliate, tubers number, dry mass of the aerial part, dry mass of the roots, dry mass of the tubers, aerial/roots ratio, potato productivity, content of dry matter, content of soluble solids. The statistical design was of splitsplot in the time for the appraised parameters during the physiologic development and randomized blocks for the analysis of the productivity. In the experiment 2, with Atlantic, Jatte-Bintje and Monalisa cultivars; the $\mathrm{CO}_{2}$ levels 
were: $\mathrm{T} 1=0, \mathrm{~T} 2=145,36$ and $\mathrm{T} 3=290,72 \mathrm{~kg} \mathrm{ha}^{-1}$. The appraised parameters were the same ones that in the experiment 1, including the soil $\mathrm{pH}, \mathrm{pulp} \mathrm{pH}$, acidity, firmness of the pulp, the content of soluble solids, color of the pulp, content of dry matter, reducers sugars and starch of the tubers. The design statistical was analysis of multiple regression for the appraised parameters during the physiologic development and randomized block design with factorial arrangement $3 \times 3$ for the analysis productivity, pulp $\mathrm{pH}$, acidity, pulp firmness, content of soluble solids, pulp color, content of dry matter, reducers sugars and starch of the tubers. From the experiment 1 it was concluded that cultivar Itarare did not present variation of total productivity with the increase of the $\mathrm{CO}_{2}$ levels; more than $50 \%$ of the commercial production of the Itararé cultivar was classified as special class independent of the $\mathrm{CO}_{2}$ levels; content of soluble solids in the tubers of the Itararé cultivar decreased with the increase of the $\mathrm{CO}_{2}$ levels. From the experiment 2 it was concluded that the total productivity of potato in Atlantic, Jatte-Bintje and Monalisa cultivars decreased with increasing of the $\mathrm{CO}_{2}$ levels; Monalisa cultivar presented larger productivity than Jatte-Bintje and Atlantic cultivars, respectively, independent of the $\mathrm{CO}_{2}$ levels; Atlantic cultivar presented larger percentage of tubers of special class than the Monalisa and Jatte-Bintje cultivars, respectively, independent of the amount of applied $\mathrm{CO}_{2}$; the application of $\mathrm{CO}_{2}$ in Atlantic, Jatte-Bintje and Monalisa cultivars did not alter the acidity significantly and the content of soluble solids and the content of dry matter of the tubers. However, the tubers of the Monalisa and Atlantic cultivars lost firmness and the Jatte-Bintje cultivar did not suffer impact of the treatment; the Atlantic and Jatte-Bintje cultivars ranged the content of starch with the application of $\mathrm{CO}_{2}$. Besides, the content of reducers sugars in Jatte-Bintje cultivar increased with the treatment application. 


\title{
1 INTRODUÇÃo
}

\begin{abstract}
A batata (Solanum tuberosum) é uma das hortaliças de maior importância sócio-econômica no Brasil e a quarta fonte de alimentos para a humanidade, superada apenas pelo arroz, milho e trigo (Althoff \& Silva, 1998). Tem ocorrido um incremento na produção nacional, devido ao aumento da produtividade por área, decorrente principalmente da melhoria do material de propagação, permitindo, o melhor aproveitamento dos insumos modernos utilizados (Dias, 1993).

Em países onde a agricultura irrigada é plenamente dominada, uma das práticas utilizadas é a aplicação de fertilizantes, herbicidas e inseticidas, via água de irrigação, também denominada "fertirrigação" (Costa et al., 1986). Avanços tecnológicos na área de irrigação e carbonatação da água fizeram da fertilização com gás carbônico uma opção de ponta a ser considerada na bataticultura. $O$ $\mathrm{CO}_{2}$ absorvido é fixado e transformado em carbohidratos, por meio de processos metabólicos específicos, que ocorrem no interior do tecido vegetal. O incremento na absorção de $\mathrm{CO}_{2}$, aumenta a eficiência fotossintética das plantas, acarretando conseqüentemente, maior produtividade e qualidade. Além desse mecanismo, há outros fatores que atuam sinergicamente sobre a planta, aumentando a eficiência do processo de fertilização carbônica (Durão \& Galvão, 1995).
\end{abstract}


$O$ presente experimento teve por objetivo determinar os efeitos da aplicação de diferentes dosagens de $\mathrm{CO}_{2}$, via sistema de irrigação por gotejamento, na produtividade e qualidade do tubérculo da batata, em condições de campo aberto. 


\section{REVISÃO DE LITERATURA}

\subsection{Irrigação localizada}

A irrigação localizada consiste na aplicação de água diretamente sobre a região radicular, em pequenas quantidades e com alta freqüência, tendo-se a opção de manter a umidade do solo próximo ao ideal para o desenvolvimento da planta. O sistema por gotejamento pode ser constituído por tubogotejadores, gotejadores on line ou gotejadores in line (Marouelli et al., 1994).

San Juan (1988) caracaterizou o gotejamento como o sistema que consegue manter a água na zona radicular nas condições de utilização mais favoráveis à planta.

Segundo Karmeli \& Keller (1974), a uniformidade de aplicação de água na irrigação por gotejamento é afetada pelos seguintes fatores: variações na pressão devido a perdas de carga ou elevações no terreno, variações entre emissores devido ao processo de fabricação e possíveis entupimentos. Os autores desenvolveram técnicas e critérios para determinar a uniformidade de distribuição da irrigação por gotejamento. Foi definida a uniformidade de emissão (Eua) em função dos parâmetros vazão mínima e a vazão máxima na parcela. Estabeleceram como regra geral que um sistema de irrigação por gotejamento não deve ser projetado para valor de uniformidade de emissão absoluta ( $\left.E_{\text {ua }}\right)$ menor que $90 \%$.

$\mathrm{Na}$ irrigação por gotejamento, as raízes se concentram em um volume reduzido de solo, razão pela qual a aplicação de fertilizantes através da rede 
de irrigação deve ser logicamente mais eficiente que com os sistemas tradicionais, tanto de irrigação como de fertilização.

Bernardo (1995) relata que a irrigação por gotejamento compreende os sistemas de irrigação nos quais a água é aplicada ao solo, diretamente sobre a região radicular em pequenas vazões (1-10 $L^{-1}$ ) porém com alta freqüência, de modo que mantenha a umidade do solo na zona radicular próximo a "capacidade de campo". Assim sendo, a aplicação de água é feita através de tubos perfurados com orifícios de diâmetros reduzidos ou por meio de pequenas peças denominadas gotejadores, conectadas em tubulações flexíveis de polietileno, trabalhando a pressão entre 0,5 a 2,5 atmosferas (atm), sendo que a pressão de serviço da maioria dos tipos de gotejadores está em torno de 1 atm.

O sistema consta de tubos de plástico furados ou providos de gotejadores, colocados na superfície do solo ao longo das fileiras das plantas, e de uma tubulação principal para o abastecimento de água. Os tubos permanecem no terreno durante o ciclo vegetativo, gotejando a água no solo diariamente. Este permite a aplicação de fertilizantes solúveis pela água de irrigação.

A maior vantagem do gotejamento em relação aos outros sistemas consiste no excelente controle na aplicação da água. Esta é distribuída diariamente na quantidade mais próxima possível à do consumo da planta. $\mathrm{A}$ evaporação da superfície do solo é mínima e a percolação profunda é quase inteiramente eliminada.

O déficit de umidade no solo permanece em nível muito baixo pela irrigação diária, sendo mantida a aeração do solo. Adicionando-se fertilizantes à água, estes são transportados diretamente às raízes das plantas e, na forma solúvel, são absorvidos quase de imediato pela cultura (Withers \& Vipond, 1977).

\subsubsection{Características de irrigação por gotejamento}


Segundo Abréu et al. (1987) e San Juan (1988), a irrigação por gotejamento apresenta as seguintes características:

- a água é aplicada no solo desde uma fonte que pode se considerar pontual, infiltra-se no terreno e se movimenta na direção horizontal e vertical,

- não ocorre molhamento total do solo, mas sim parcial, que varia com as características do solo, a vazão do gotejador e o tempo de aplicação. Nesta parte úmida é onde há maior concentração de raízes e onde ocorre o processo de absorção,

- como existem zonas secas não exploradas pelas raízes e zonas úmidas, podese considerar de certo modo um cultivo em faixa ou sulcos, mas com um sistema radicular inferior ao normal,

- a manutenção de um nível ótimo de umidade no solo implica em uma baixa tensão de água no mesmo. O nível de umidade que se mantém no solo permanece constantemente próximo à capacidade de campo.

- requer uma adubação freqüente, porque como conseqüência do movimento permanente da água no bulbo pode se produzir uma lixiviação excessiva de nutrientes.

Alguns problemas apresentados pelo sistema de irrigação por gotejamento são descritos por Bernardo (1989):

- Entupimento - sendo o diâmetro dos orifícios muito pequeno a exigência de água limpa é uma característica inerente. A fim de minimizar a ocorrência de entupimento, a filtragem e o controle de $\mathrm{pH}$ da água faz parte do próprio sistema, para evitar a obstrução dos gotejadores causada por partículas minerais, orgânicas ou precipitados.

- Distribuição no sistema radicular - devido à formação e manutenção de um volume constante de solo umedecido, as raízes dos vegetais tendem a concentrar-se nesta região, diminuindo a estabilidade das árvores em regiões sujeitas a ventos com maior intensidade. 
A seleção do método para a aplicação de produtos químicos em sistemas de irrigação localizada depende da situação onde a prática é utilizada e das características de funcionamento do método (Mello et. al., 1992).

Os métodos mais apropriados para serem utilizados em sistemas de irrigação localizada são o de pressão diferencial (com o tanque de derivação de fluxo) e o de pressão positiva com a bomba injetora. O primeiro apresenta baixo custo, fácil construção, instalação e operação e não requer fonte de energia externa, apesar da uniformidade de distribuição do produto ao longo de tempo não ser perfeita e da dificuldade de deslocamento e automatização do equipamento. $O$ segundo, por manter a concentração da solução injetada, permite fácil automatização e regulagem, embora apresente custo relativamente mais elevado, e requerer fonte de energia (Mello et. al., 1992).

São vários os aspectos favoráveis à utilização da aplicação de produtos químicos nos sistemas de irrigação localizada, devido à alta eficiência e à redução dos custos de aplicação desses produtos, quando comparados aos métodos tradicionais de aplicação.

A variação da concentração da solução na água de irrigação durante a aplicação afeta diretamente a uniformidade de aplicação do produto nas linhas de plantio, principalmente, quando se têm blocos operacionais e linhas laterais grandes. Esta variação ocorre ao longo do tempo de irrigação, influenciada pelo tipo e a capacidade do equipamento, o produto e a sua taxa de aplicação (Mello et. al., 1992).

Zanini (1987) indica que a maioria dos produtos devem ser injetados em um tempo não inferior de 30 a 40 minutos, devendo-se evitar interrupções e reinicio de aplicação, o que prejudicaria a uniformidade de distribuição da substância aplicada æ̀̀ plantas.

\subsubsection{Respostas das plantas ao sistema de irrigação por gotejamento}


A irrigação por gotejamento permite uma aplicação dos nutrientes ajustada às necessidades da planta, que responde de maneira rápida à fertilização. Conhecendo-se as distintas formas em que os elementos nutritivos estão presentes no fertilizante, pode-se melhor utilizar aquele que permita uma melhor e mais rápida absorção pela planta, ajustando-se conforme a necessidade (Ferreres, 1981).

Os adubos que têm uma ação concreta sobre determinados processos de desenvolvimento da planta são mais bem aproveitados por meio do gotejamento. Assim, as necessidades de fósforo têm lugar especialmente nas primeiras fases que é quando ocorre o desenvolvimento radicular. Da mesma forma ocorre com o potássio, cujas necessidades são maiores nas plantas no momento que o fruto começa aumentar de tamanho (Ferreres, 1981).

\subsection{Considerações gerais sobre a batateira}

A batata (Solanum tuberosum L.) é nativa da América do Sul, da cordilheira dos Andes, onde foi consumida por populações nativas em tempos que remontam a mais de 8.000 anos. Foi introduzida na Europa por volta de 1570, provavelmente por meio de colonizadores espanhóis, tornando-se um alimento importante na Inglaterra. Por volta de 1620, foi levada da Europa para a América do Norte, onde se tornou alimento popular. Atualmente a batata ocupa o $4^{\circ}$ lugar entre os alimentos mais consumidos no mundo, sendo superada apenas pelo trigo, arroz e milho (FAO, 1996; EMBRAPA-CNPH, 1997a).

Mundialmente são cultivadas aproximadamente 19,0 milhões de hectares ano $^{-1}$, com rendimento médio de 16,6 tha ${ }^{-1}$. Sendo, China (3.802.000 ha), Russia (3.250.000 ha), Ucrânia (1.560.000 ha), Polonia (1.251.000 ha) e India (1.300.000 
ha) responsáveis do $60 \%$ da área plantada e $50 \%$ da produção mundial (FNP CONSULTORIA \& COMÉRCIO, 2000).

No Brasil, em 2000 foram plantadas 152.000 ha com uma produção total de 2,6 milhões de toneladas, apresentando um rendimento médio de $16,9 \mathrm{t} \mathrm{ha}^{-1}$, sendo superado ainda pela produção da Argentina (3,5 milhões t ano $\left.{ }^{1}\right)$, Peru (3,2 milhões t ano $\left.{ }^{-1}\right)$, e Colômbia $\left(2,7\right.$ milhões $\left.\operatorname{t~ano~}^{-1}\right)$.

As regiões responsáveis pela maior produção brasileira no ano 2000 foram, Sudeste: Minas Gerais (707.570 t), seguido de são Paulo (633.520 t) e sul: Paraná (631.730 t), seguido de Rio Grande do Sul (391.183 t).

\subsubsection{Descrição das variedades estudadas}

\subsubsection{Itararé}

De origem brasileira, (progenitores: Arensa x Turma x Leo). As plantas são muito vigorosas, com bom aspecto vegetativo e porte alto. Hastes eretas, folhas longas, poucas flores, de cor branca. Frutificação escassa. Ciclo tardio, porém com tuberização precoce (aproximadamente 70 dias). Os tubérculos têm formato oval-alongado ligeiramente achatado, película amarelo-escura, opaca e áspera. "olhos" salientes, polpa amarela. Porcentagem muito grande de tubérculos comerciais. Boa resistência à requeima e à pinta preta, alta resistência ao vírus do enrolamento das folhas. O teor de matéria seca é de baixo a médio. De maneira geral, possui qualidades culinárias consideradas intermediárias. Cultivar bem produtiva, a tendência a produzir tubérculos demasiadamente grandes pode dificultar a produção de batata-semente nos padrões exigidos (EMBRAPA CNPH, 1997a). 


\subsubsection{Atlantic}

Originária de Estados Unidos (batata-semente produzida e comercializada pelo Canadá). Progenitores: Wauseon x B 5451-6 (Lenape). Plantas vigorosas, com hastes grossas, eretas, ciclo médio de 95 dias e flores de coloração rosa. As folhas são grandes e verde-claras. Tubérculos de formato oval-arredondado, película amarela ligeiramente rendilhada, "olhos" medianamente profundos, polpa branca. Suscetível ao coração-oco quando plantada em espaçamentos largos. Dormência média. Moderadamente resistente àrequeima e muito resistente ao vírus $X$. Resistência baixa ou intermediária às demais doenças de maior importância no país. Indicada para processamento como palitos fritos. Porém, produz palitos curtos por ter tubérculos arredondados. Especialmente indicada para produção de "chips", por apresentar alto teor de matéria seca e pelo formato do tubérculo. Apresenta grande adaptação e estabilidade de produção nas diferentes regiões produtoras, quase sempre com alta porcentagem de tubérculos graúdos (EMBRAPA - CNPH, 1997a).

\subsubsection{Jatte-Bintje}

Originária de Suécia. Progenitores: mutação da 'Bintje'. Plantas com bom desenvolvimento vegetativo, mais vigorosas e mais rústicas que 'Bintje'. Poucas hastes, com pigmentação violeta, acamamento regular, indicada para climas mais frios. Ciclo tardio. Tubérculos com formato ovatalongado, uniformes e graúdos, com "olhos" superficiais e película amarela lisa e brilhante, de ótima aparência. Polpa de cor creme. Boa resistência ao esverdeamento e muito sensível ao embonecamento. Baixa resistência à maioria das doenças principais, porém um pouco mais resistente que a 'Bintje'. Presta-se bem para fritura por conter alto 
teor de matéria seca. Também é boa para confecção de purês e saladas (EMBRAPA - CNPH, 1997a; Santos, 1986).

\subsubsection{Monalisa}

Originaria da Holanda, (progenitores: Bierna A1 - 287 x Colmo). Plantas vigorosas, folhagem de desenvolvimento lento, hastes pouco numerosas, grossas, de cor ligeiramente violácea. Folhas bastante grandes, verde-claras. Folíolos grandes, ovais com pecíolos compridos. Hábito de crescimento semi-erecta, acamamento regular. Floração pobre, pequena inflorescência, com flores brancas. Ciclo vegetativo variando entre 90 e 110 dias. Tubérculos com formato oval-alongado, película amarela, lisa, brilhante, "olhos" superficiais, polpa amarela. Medianamente sensível ao embonecamento e rachaduras, susceptível a murcha bacteriana. Baixo teor de matéria seca. Resistente ao esverdeamento. Resistência intermediária à requeima, à pinta-preta e à rizoctoniose. Boa resistência ao vírus do enrolamento das folhas e resistência intermediária aos mosaicos (PVY e PVX). Não se presta à fritura, sendo adequada porém para purês e saladas. Boa estabilidade de produção, produzindo em média 50\% de tubérculos com tamanho comercial (EMBRAPA - CNPH, 1997a; Santos, 1986).

\subsection{2 Épocas de plantio}

O Brasil, com a situação privilegiada em termos de solo e clima, planta e colhe batata todos os meses do ano. A época de plantio, a altitude e a latitude do terreno condicionam as condições agroecológicas (Filgueira, 1999).

As principais safras na cultura da batata nas principais áreas das regiões Sul e Sudeste do Brasil são: 
A "das águas", que é plantada em agosto-dezembro e colhida de novembro em diante. O plantio "de inverno", realizado de abril a julho e colhido em julho-outubro, é também praticado nessas mesmas regiões, em locais onde não ocorrem geadas, mas depende de irrigações durante o ciclo. Já o cultivo "da seca", que começa em janeiro-março, deve ser realizado o mais cedo possível para evitar as geadas em regiões onde ocorre inverno rigoroso (EMBRAPA - CNPH, 1997a)

\subsubsection{Fases da cultura}

\subsubsection{Fase inicial}

A fase de estabelecimento da batateira compreende o período do plantio à emergência e tem duração de 10 a 20 dias. Depende de uma série de fatores como a umidade, a temperatura do solo e o grau de brotação do tubérculosemente. A deficiência de água pode provocar desigualdade na emergência e ressecamento de brotos.

\subsubsection{Fase vegetativa}

Vai da emergência ao início de tuberização (30-40 dias). A duração pode ser afetada pela temperatura, presença de água e nutrientes do solo e também pelo comprimento do dia (em dias longos as plantas crescem por um período maior). A deficiência moderada de água nesta fase pode limitar 0 desenvolvimento da planta, mas não chega a comprometer a produção. 


\subsubsection{Fase de tuberização}

Período entre o início da tuberização até o início da senescência (45-55 dias). Terá maior ou menor duração dependendo do comprimento do ciclo (longo ou curto), da cultivar plantada e da destinação da produção (para consumo ou semente). É a fase do ciclo mais crítica à deficiência de água.

\subsubsection{Fase de senescência}

Do início da senescência até a colheita (10-15 dias). Nesta fase há uma redução acentuada do consumo de água pela cultura (EMBRAPA - CNPH, 1997a; EMBRAPA - CNPH, 1997b).

\subsubsection{Extração de nutrientes}

O conhecimento das exigências nutricionais é pré-requisito para se estabelecer a quantidade de fertilizantes que deve ser aplicado para, pelo menos, manter a fertilidade do solo (Magalhães, 1985).

Em Campinas, Garantini (1963), realizou pesquisas sobre absorção de nutrientes da batateira cultivar Bintje em um solo areno-argiloso, adubando com o equivalente a 80-120-60 $\mathrm{kg}^{-1}$ dos três macronutrientes, $\mathrm{N}, \mathrm{P}_{2} \mathrm{O}_{5}, \mathrm{~K}_{2} \mathrm{O}$. Obteve uma produção de $15 \mathrm{t}$ de tubérculos e $6 \mathrm{t}$ de parte aérea ha ${ }^{-1}$, sendo os seguintes os níveis de macronutrientes extraídos: potássio 112, nitrogênio 56, cálcio 16 , enxofre 13, fósforo 11 e magnésio $9 \mathrm{~kg} \mathrm{ha}^{-1}$ respectivamente. 


\subsubsection{Período de exigência e acúmulo de nutrientes}

A época de aplicações dos adubos é função de diversas variáveis, como período de exigência da cultura, condições de solo e de clima, elementos, forma em que é fornecido e tipo de adubação (Magalhães, 1985).

$\mathrm{Na}$ batateira, a primeira fase é bastante curta, iniciando rapidamente a elevada taxa de crescimento. As necessidades iniciais de $\mathrm{N}$ podem indicar a necessidade de fracionar as aplicações dos adubos nitrogenados. É essencial a disponibilidade de $\mathrm{N}$ no início do ciclo, visto que a cultura absorve $41 \%$ de nutrientes nos 20 dias após a emergência dos brotos (Magalhães, 1985).

Se o solo tiver alto teor de matéria orgânica (M.O > 3\%), a quantidade de N no plantio pode ser reduzida em $20 \%$. Posteriormente, deve-se avaliar o estado nutricional nitrogenado da cultura, analisando-se o teor de $\mathrm{N}$ na quarta folha completamente desenvolvida, aos 20 dias após a completa emergência das plantas (EPAMIG, 1999).

Recomenda-se o fracionamento dos adubos fosfatados, colocando-se $80 \%$ do recomendado no sulco de plantio e incorporando-se o restante por ocasião da amontoa.

Quanto aos adubos potássicos, devem ser adicionados em função do teor existente, colocando-se $30 \%$ do recomendado no sulco de plantio e incorporandose o restante ao solo, imediatamente antes da amontoa (EPAMIG, 1999).

Hawkins (1946), trabalhando com a cv. Green Mountain no Maine (EUA), com uma população de 37.037 plantas ha ${ }^{-1}$, uma adubação de $126 \mathrm{~kg} \mathrm{ha}^{-1}$ de $\mathrm{N}$, $252 \mathrm{~kg} \mathrm{ha}^{-1}$ de $\mathrm{P}_{2} \mathrm{O}_{5}$ e $252 \mathrm{~kg} \mathrm{ha}^{-1}$ de $\mathrm{K}_{2} \mathrm{O}$ e uma produtividade de $29 \mathrm{t} \mathrm{ha}^{-1}$, observou que o acúmulo máximo de todos os macronutrientes ocorreu cerca de 10 dias antes de se atingir produção máxima de material seco e que o acúmulo maior de matéria seca (MS) da parte aérea ocorreu entre 61-70 dias, e para os 
tubérculos, entre 82-91 dias após plantio. O acúmulo máximo de MS total ocorreu 85 dias após plantio. Alem disso, reportou que os tubérculos acumularam as maiores quantidades de $\mathrm{N}, \mathrm{P}$, e $\mathrm{S}$ e, a parte aérea, as maiores quantidades de Ca e Mg. $\mathrm{O}$ acúmulo de $\mathrm{K}$ foi semelhante tanto na parte aérea como nos tubérculos.

Yorinori (2003), com objetivo de determinar as curvas de crescimento de massa de material seco, o acúmulo máximo e a exportação de nutrientes, realizou um trabalho em Itapetininga-SP em duas safras (das águas e da seca) na cv. Atlantic, com uma população de 41.667 plantas ha $^{-1}$ e uma produtividade de $36,5 \mathrm{t}$ $\mathrm{ha}^{-1}$ aos 111 DAP para a safra das águas e $24 \mathrm{t} \mathrm{ha}^{-1}$ aos 90 DAP para a safra da seca. Concluiu que a safra das águas produziu mais massa de material seco que a safra da seca. A seqüência de acúmulo máximo na safra das águas foi: $\mathrm{N}>\mathrm{K}>\mathrm{Ca}>\mathrm{P}>\mathrm{Mg}>\mathrm{S}>\mathrm{Fe}>\mathrm{Mn}>\mathrm{Zn}>\mathrm{B}>\mathrm{Cu}$. Na safra da seca, o $\mathrm{K}$ trocou de posição com o $\mathrm{N}$ e o $\mathrm{P}$ com o $\mathrm{Ca}$. O acúmulo máximo dos nutrientes depende da safra $\mathrm{e}$ do nutriente: N (140 e 119); P (17,6 e 15,2); K (134 e 139); Ca (21,7 e 14,6); Mg $(14,3$ e 6,9); S (10,8 e 14,6) em Kg ha-1; B (107 e 84,3); Cu (43,5 e 38,9); Fe (1.229 e 790); Mn (250 e 130); Zn (156,6 e 124,6) em $\mathrm{g} \mathrm{ha}^{-1}$ para as safras das águas e da seca respectivamente.

\subsubsection{Qualidade dos tubérculos}

O mercado, com a incorporação de novas tecnologias produtivas, a redução de custos e o lançamento de novos produtos, tende a direcionar ao aumento de consumo por parte dos consumidores mais exigentes em qualidade tecnológica e comodidade (FNP CONSULTORIA \& COMÉRCIO, 2001, 2002).

A batata, uma vez colhida, destina-se para o consumo em forma de cozimento e como matéria prima para a industria elaborada. Segundo NIVAA (2003), as batatas destinadas ao setor de elaboração devem cumprir vários 
requisitos em relação às seguintes características de qualidade: tamanho e forma de tubérculos, danos e defeitos, conteúdo em matéria seca, conteúdo em açúcares redutores e escurecimento não enzimático.

$\operatorname{NIVAA}^{1}(2000)$ citado por Feltran (2002), classifica como adequados para fritas na forma de palito, tubérculos com teores de matéria seca entre 20 e $24 \%$ e com até $0,5 \%$ de açúcares redutores (base seca), enquanto para chips recomenda entre 22 e $24 \%$ de matéria seca e máximo de 0,3\% de açúcares redutores.

$\mathrm{Na}$ industria alimentícia a qualidade é de fundamental importância e 0 conteúdo de matéria seca deve ser alto para evitar a excessiva absorção de gordura durante a produção de produtos processados como fritas, chips, etc. (Storey \& Davies, 1992).

Cacace et al. (1994) sugeriram agrupar os teores de matéria seca em três grupos: alto conteúdo de matéria seca (teores maiores que 20\%); conteúdo intermediário de matéria seca (teores entre 18,0 e 19,9\%) e baixo conteúdo de matéria seca (teores inferiores a 17,9\%). Burton (1989) indicou teores de matéria seca entre 21,7 e $24,8 \%$ para os tubérculos.

As quantidades de açúcares presentes nos tubérculos de batata são variáveis, sendo os principais açúcares a sacarose, a glicose e a frutose (Kadam et al., 1991).

Os açúcares glicose e frutose são classificados como redutores pela capacidade de reduzir agentes oxidantes como ferrocianeto, peróxido de hidrogênio e o íon $\mathrm{Cu}^{2+}$ (Lelhinger, 1988). Segundo Pereira (1987), a sacarose classificada como açúcar não redutor, não afeta a qualidade dos produtos finais, desde que sejam obtidos de tubérculos recém colhidos.

\footnotetext{
${ }^{1}$ NIVAA. On the road to processing. [on line]. 2000.ttp//www.nivaa.nl/nivap/ontheroad.html. [14 abr. 2000].
} 
O conteúdo de açúcares redutores (glicose e frutose) influencia a intensidade de coloração das frituras e o ideal é que seja baixo para evitar o excessivo escurecimento (Woolfe ${ }^{2}$ (1987) citado por Donnelly et al., 2001c).

O escurecimento não enzimático, produto dos processos de fritura, tem sido atribuído à reação entre os açúcares redutores, os amino-ácidos e proteínas (reação de Mailard) e posteriormente, com a extensão do processo de fritura, à queima do produto (caramelização), resultando em sabor amargo (Shallemberger et al., 1959).

Kadam et al. (1991) reportaram uma variação média, em base seca, de 0,5 a $1,0 \%$ para sacarose e de 0,5 a 2,0\% para os açucares redutores. Já Pereira (1987), indicou que tubérculos com mais de 2,0\% (base seca) de açúcares redutores são considerados inaceitáveis para o processamento.

Segundo Paschoalino (1993), um teor de açúcares redutores menor que $0,1 \%$ indica que a batata é boa para fritura ('Bintje', 'Cristal', e 'Atlantic'); entre 0,1 e $0,3 \%$ indica que a qualidade de batata é duvidosa ('Piratini' e 'Cerrito Alegre') e acima deste percentual, a batata não é adequada para a fritura ('BR-3', 'Trapeira', 'Santo Amor', 'Monte Bonito', 'Macaca', 'Baronesa', e 'Cascata').

Feltran (2002) estudando a qualidade dos tubérculos em diferentes variedades, reportou $17,9 \%$ de matéria seca, 64,1\% (base seca) de amido, 0,51\% de açucares redutores, 0,16\% de acidez titulável, e 5,19Brix para a variedade Bintje e 6,42Bㅜㅅㅣ para a variedade Itararé.

O principal componente dos tubérculos de batata é o amido, que é um polímero de glicose e fonte de energia para os seres vivos. A quantidade de amido presente nos tubérculos depende dos cultivares, da forma de condução (controle de doenças e pragas) e da temperatura de armazenamento após colheita (Kadam et al., 1991). Segundo Pereira (1987), o teor de amido compõe

\footnotetext{
${ }^{2}$ Woolfe, J. The potato in the human diet. Cambridge U.K: Cambridge University, 1987.231p.
} 
de 65 a $80 \%$ do peso dos tubérculos, compreendendo a maior parte da matéria seca.

Existe evidência que fatores ambientais podem afetar tanto os níveis de amido quanto outros atributos de qualidade como conteúdo de açúcar e glicoalcaloides que podem influenciar o sabor (Haase \& Plate, 1996; Donnelly et al., 2001c).

O conteúdo de amido dos tubérculos é um importante critério na escolha de tubérculos de batata para a produção industrial de amido (Lindhauer \& De Fekete, 1990). O teor médio de amido nos tubérculos de batata é de $65-75 \%$ da matéria seca e $16 \%$ da matéria fresca dos mesmos (Burton, 1989).

\subsection{Dióxido de carbono $\left(\mathrm{CO}_{2}\right)$}

O ciclo de carbono na biosfera tem sido significativamente alterado pela atividade do homem nos últimos 150 anos. O $\mathrm{CO}_{2}$ emitido pela atividade humana é da ordem de 8,5 bilhões de toneladas anuais. Vários modelos teóricos predissem que a temperatura média global do ar aumentará 3 a $4^{\circ} \mathrm{C}$ (Manabe \& Wetherald, 1967) e como conseqüência a concentração de $\mathrm{CO}_{2}$ na atmosfera pode dobrar antes do ano 2025 (Gribbin, 1981).

Estudos relacionados aos efeitos de aumento artificial da concentração de $\mathrm{CO}_{2}$ sobre as plantas usadas para obtenção de produtos em maior quantidade e melhor qualidade permite-nos conhecer a capacidade das plantas de adaptar-se a esses ambientes (Pinto, 1997).

Acredita-se que as plantas terrestres fixam aproximadamente 25 bilhões de toneladas por ano. $\mathrm{O} \mathrm{CO}_{2}$ atmosférico aparece limitando a fotossíntese, devida que, a maioria das plantas $\mathrm{C} 3$ são capazes de fixar maiores taxas de $\mathrm{CO}_{2}$ 
na presença de altas concentrações de $\mathrm{CO}_{2}$ presente na atmosfera (Bolin ${ }^{3}(1970)$; citado por Arteca et al., 1979).

$\mathrm{O}$ aumento da concentração de $\mathrm{CO}_{2}$ está relacionado com o aumento da biomassa, do peso foliar e diminuição do peso específico, em virtude do aumento de açúcares nas folhas, pelo incremento de carboidratos que se armazenam nestes órgãos. Quando as plantas são submetidas a tratamentos prolongados com $\mathrm{CO}_{2}$, a eficiência fotossintética diminui (Goto \& Tivelli, 1997).

Os níveis de $\mathrm{CO}_{2}$ na atmosfera do solo variam consideravelmente; Stolzy ${ }^{4}$ (1974) citado por Baron \& Gorski (1986), encontrou concentrações de $\mathrm{CO}_{2}$ que variaram de 0,03 a $25 \%$.

A prática de fertilização carbônica, até a última década empregada apenas em cultivos feitos em estufas fechadas, pode agora ser utilizada em estufas semi-abertas e abertas. Avanços tecnológicos na área de irrigação e carbonatação da água fizeram da fertilização com gás carbônico uma opção viável tanto do ponto de vista técnico como econômico (Durão \& Galvão, 1995).

A aplicação de gás carbônico nas culturas melhora o metabolismo e o equilíbrio hormonal das plantas, aumenta a fotossíntese e a absorção de nutrientes, resultando em plantas mais produtivas, mais resistentes a doenças e ao ataque de pragas, gerando frutos de melhor qualidade (Kimball et al., 1994).

Esta tecnologia consolidou-se no início dos anos 60, após intenso trabalho de pesquisa desenvolvido na década anterior por pesquisadores norteamericanos e europeus. A fonte de $\mathrm{CO}_{2}$ utilizada até então, era o querosene e o propano, cuja combustão no interior de estufas gerava, além de $\mathrm{CO}_{2}$, subprodutos altamente tóxicos para os vegetais, como o propileno, o monóxido de carbono e o óxido de enxofre.

\footnotetext{
${ }^{3}$ Bolin, B. Sci. Am. v.23, n.3, p.125, 1970.

${ }^{4}$ Stolzy, L.H. Soil atmosphere. In: The Plant Root and Its Environment, Charlottesville: University Press of Virginia. 1974. p.335-362.
} 
A partir dos anos 80, desenvolveram-se novas tecnologias de irrigação localizada, gotejamento e microaspersão, e métodos mais eficientes de carbonatação da água (Durão \& Galvão, 1995).

No final dos anos 80, empresas norte americanas que comercializavam gás carbônico para indústrias, interessaram-se pelo processo na atividade agrícola e iniciaram trabalhos œm injeção de gás carbônico na água utilizada para irrigação, em culturas a céu aberto, visando aumentar a sua produtividade, com resultados promissores (Sanches, 1992; Idso \& Idso, 1994).

No Brasil, as aplicações de dióxido de carbono via água de irrigação são de uso recente e poucos são os estudos ecofisiológicos referentes às trocas de $\mathrm{CO}_{2}$ em plantas. Existem, ainda, muitos aspectos a esclarecer com relação aos efeitos sobre as plantas, influência na produtividade, melhoria da qualidade de frutos, doses a serem usadas e períodos de aplicação mais adequados para os diferentes tipos de cultivo, para alcançar uma relação custo/beneficio máxima (Pinto, 1997).

\subsection{Metabolismo fotossintético na batateira}

O carbono é o principal componente químico dos vegetais, constituindo aproximadamente $45 \%$ da sua matéria seca. A fonte desse carbono é o $\mathrm{CO}_{2}$ da atmosfera terrestre, que é absorvido pela planta durante a fotossíntese, através de microscópicas aberturas na superfície das folhas, denominados estômatos. $\mathrm{O}$ $\mathrm{CO}_{2}$ absorvido é fixado e transformado em carbohidratos, por meio de processos metabólicos específicos que ocorrem no interior de tecido vegetal. A concentração normal desse gás na atmosfera é de aproximadamente 340 ppm (partes por milhão). Considera-se que essa concentração é pouco adequada para o pleno funcionamento do processo fotossintético nos vegetais (Durão \& Galvão, 1995). 
Absorvido pelos estômatos, $\mathrm{O} \mathrm{CO}_{2}$ percorre os espaços inter e intracelulares do tecido vegetal, até atingir o interior das células chamadas de cloroplastos, local exato onde será desencadeada a fixação do carbono ao tecido vegetal. Em batata, esse metabolismo tem início graças à ação de uma importante enzima, a rebulose-bifosfato caboxilase/oxigenase (RUBISCO), responsável pela reação inicial de fixação do $\mathrm{CO}_{2}$ na seqüência de reações químicas do ciclo de Calvin. A dupla atividade química dessa enzima é regulada pela relação da concentração dos gases $\mathrm{CO}_{2}$ e $\mathrm{O}_{2}$. A concentração natural do oxigênio na atmosfera, de $21 \%$, tem ação inibitória sobre a fixação de $\mathrm{CO}_{2} \mathrm{e}$ desencadeia um fenômeno fisiológico conhecido como fotorrespiração que provoca perda de carbono pela planta (Durão \& Galvão, 1995).

Em condições de campo, e a longo prazo, existiria a possibilidade de incrementar a fixação de $\mathrm{CO}_{2}$ se fossem encontradas linhas nas quais a RUBISCO tivera maior afinidade pelo $\mathrm{CO}_{2}$ ou diminuíra sua capacidade de atuar como oxigenasse ou o ritmo de degradação da RUBISCO para o final do ciclo da cultura fosse menor (Caldiz, 1994).

A eficiência fotossintética é maior no horário da manhã, entre 8:00 e 10:00 $\mathrm{h}$, e também entre às 14:00 e 16:00 h, períodos nos quais ocorrem picos de absorção de $\mathrm{CO}_{2}$.

Pesquisas desenvolvidas nas últimas três décadas revelaram que a elevação artificial da concentração de $\mathrm{CO}_{2}$ no microclima, criado pela massa foliar dos vegetais, elimina parcial ou totalmente o processo de fotorrespiração, evitando perda de $\mathrm{CO}_{2}$ pela planta e incrementando assim a absorção líquida. Esse incremento na absorção de $\mathrm{CO}_{2}$ aumenta a carboxilação da RUBISCO resultando numa maior produtividade vegetal (Durão \& Galvão, 1995).

Além desse mecanismo, há evidências de que outros fatores atuam sinergicamente sobre a planta, aumentando a eficiência do processo de fertilização carbônica. Plantas sob enriquecimento atmosférico utilizam com mais 
eficiência as reservas de água do tecido vegetal e perdem menor quantidade de água pelos estômatos, pois, conseguem mantê-los ligeiramente mais fechados do que em condições normais.

Também admite-se que a fertilização carbônica pode interferir positivamente no balanço hormonal da planta, na absorção de micronutrientes e na degradação de resíduos de produtos fitossanitários presentes no solo (Durão \& Galvão, 1995).

O gradiente de $\mathrm{CO}_{2}$, entre a atmosfera e o interior da folha e a condutância estomática desta última, determinam o ritmo de difusão do $\mathrm{CO}_{2}$ para 0 cloroplasto, onde se leva a cabo o processo fotossintético (Caldiz \& Gaspari, 1997).

A maior concentração de $\mathrm{CO}_{2}$ exerce um efeito positivo indireto, pois é mais eficiente a utilização da energia proveniente da cadeia transportadora de elétrons ao suprimir-se a fotorrespiração (Schapendonk et al., 1995). Porém, a longo prazo, um aumento na concentração de $\mathrm{CO}_{2}$ poderia aumentar a demanda de nutrientes, particularmente $\mathrm{N}$, e poderia modificar ambém o padrão e a distribuição de fotoassimilados.

Há variação entre espécies de plantas C3 em relação à fotossíntese, crescimento vegetativo, massa foliar e desenvolvimento do sistema radicular, quando desenvolvidas em ambientes enriquecidos com dióxido de carbono. Os efeitos comumente observados são a redução da concentração de nitrogênio nos tecidos das folhas devido à baixa taxa de transpiração, o aumento de carboidratos, a modificação da distribuição de proteínas e compostos nitrogenados e o aumento da massa fresca das folhas (Vessey et al., 1990).

A fotossíntese é o principal processo de fixação de carbono na natureza, levando à formação de carbohidratos e produção de matéria seca. Um grupo numeroso de plantas, que inclui muitas espécies de interesse agronômico como trigo, arroz, feijoeiro, cafeeiro, etc., apresenta metabolismo de tipo C3, assim 
denominado porque o primeiro produto estável identificado na carboxilação, o ácido fosfoglicérico, possui 3 átomos de carbono na molécula, formado pela carboxilação da ribulose-1,5-bifosfato, com intervenção da enzima ribulose-1,5bifosfato carboxilase-oxigenase (RUBISCO) que tem atuação funcional dupla, atuando nesse caso com sua ação carboxilase (Angelocci, 2000).

$\mathrm{O} \mathrm{CO}_{2}$ aplicado na zona radicular de plantas de batata é fixado dentro do malato, possivelmente via fosfoenolpiruvato carboxilase (PEP-Case). Este $\mathrm{CO}_{2}$ aplicado às raízes pode ser translocado até o topo da planta, onde poderia ser utilizado por ribulose-1,5-bifosfato carboxilase para suprimir a fotorrespiração. As plantas de batata são capazes de incorporar o $\mathrm{CO}_{2}$ por PEP-Case para ingressar no ciclo de ácido carboxílico ou para a síntese de aminoácidos (Arteca \& Poovaiah, 1982b; Jackson \& Coleman, 1959; Clegg \& Whittingham, 1972).

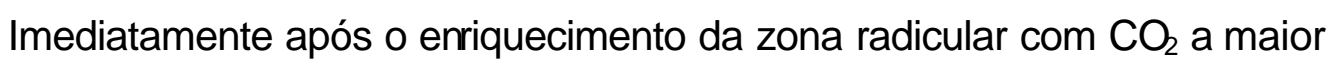
parte do $\mathrm{CO}_{2}$ translocado para o topo da planta é dissolvido na seiva do xilema, possivelmente porque as raízes não contêm suficiente atividade de PEP-Case para utilizar os níveis de carbono provido. Depois do tratamento com $\mathrm{CO}_{2}$, existe um incremento da atividade de PEP-Case e este possivelmente aumenta a quantidade de fixação de $\mathrm{CO}_{2}$ nas raízes. Este benefício inicial do enriquecimento de $\mathrm{CO}_{2}$ na zona radicular poderia resultar da translocação de $\mathrm{CO}_{2}$ para as folhas onde é utilizado por Ribulose-1,5-bifosfato carboxilase. Devido ao incremento da atividade de PEP-Case, como conseqüência da aplicação de $\mathrm{CO}_{2}$, se dá um efeito aditivo entre $\circ \mathrm{CO}_{2}$ dissolvido na seiva do xilema e o carbono assimilado pelas raízes que seriam em parte responsáveis pelo incremento e crescimento das plantas

(Arteca

et al., 1979; Arteca \& Poovaiah, 1982a). 


\subsection{Efeitos de $\mathrm{CO}_{2}$ no solo e na planta}

Um benefício potencial da irrigação com água carbonatada está relacionado na disponibilidade de nutrientes no solo. Adicionando $\mathrm{CO}_{2}$ na água ocorre acidificação da solução. Adicionando água carbonatada ao solo o pH pode diminuir temporariamente. Em solos com pH elevado, esta resposta leva os solos para um nível de $\mathrm{pH}$ desejável à disponibilidade de micronutrientes $(\mathrm{Zn}, \mathrm{Cu}$, $\mathrm{Fe}, \mathrm{Mn})$. Já em solos ácidos, esta resposta poderia causar toxidez por alumínio ou limite de disponibilidade de nutrientes essenciais da planta.

Alguns mecanismos que podem influenciar o crescimento em resposta à água carbonatada têm sido identificados. O dióxido de carbono reduz o pH da água e pode reduzir o pH do solo, resultando em um aumento de disponibilidade de alguns nutrientes. A irrigação com água carbonatada também aumenta a concentração de $\mathrm{CO}_{2}$ no solo e no ar. Isto pode aumentar o crescimento da raiz pela redução da inibição do etileno e pode estimular a atividade de certos microorganismos benéficos (Baker, 1988). O dióxido de carbono também pode ser absorvido diretamente através das raízes das plantas e fixado na fotossíntese, embora a absorção direta provavelmente não seja a maior fonte de contribuição para o incremento da produtividade. De qualquer forma, a irrigação com água carbonatada pode aumentar o nível da fotossíntese por meio do enriquecimento atmosférico. Isto também pode influenciar no balanço hormonal e de enzimas, o que permite um aumento na produtividade. A resposta de crescimento na irrigação com água carbonatada é provavelmente devido à combinação de fatores, e isto é mais fácil de ser observado onde o $\mathrm{pH}$ do solo e da água de irrigação são altos (Storlie \& Heckman, 1996).

Tognoni et al. (1967) observaram que o crescimento radicular de tomateiro foi estimulado pela elevação da concentração de $\mathrm{CO}_{2}$ no solo, e combinado a 
fatores como diminuição de $\mathrm{pH}$ do solo e como conseqüência ao incremento de absorção de nutrientes.

Nakayama \& Bucks (1980), aplicando água carbonatada diretamente no solo via sistema de irrigação por gotejo enterrado, conseguiram um incremento de $20 \%$ de rendimento em trigo e o pH decresceu em 1,5 unidades em solos calcáreos utilizados no experimento.

Araújo (2002), objetivando estudar os efeitos de $\mathrm{CO}_{2}$ dissolvido em água de irrigação, com e sem cobertura plástica do solo, conduziu um experimento a céu aberto com abobrinha em Piracicaba em dois períodos. No primeiro (maioagosto do ano 2000) obteve um rendimento de $15.433 \mathrm{Kg} \mathrm{ha}^{-1}$ utilizando $58,40 \mathrm{Kg}$ ha $^{-1}$ de $\mathrm{CO}_{2}$, associado à cobertura do solo, sendo $65 \%$ superior ao do tratamento-testemunha. No segundo (setembro-dezembro do ano 2000) obteve um rendimento de $47.098 \mathrm{Kg} \mathrm{ha}^{-1}$ aplicando $100 \mathrm{Kg} \mathrm{ha}^{-1}$ de $\mathrm{CO}_{2}$ para o solo nu, frente a $41.156 \mathrm{Kg} \mathrm{ha}^{-1}$ do tratamento-testemunha.

Hartz \& Holt (1991) observaram uma diminuição de pH (de 7,3 para 5,3) na solução do solo quando enriqueceram a água de irrigação com $\mathrm{CO}_{2}$, e esta mudança de pH foi transitória. Já Novero et al. (1991) verificaram que cinco dias depois de iniciado a aplicação de água carbonatada o $\mathrm{pH}$ reduziu e houve um incremento aparente de $\mathrm{P}, \mathrm{K}, \mathrm{Ca}, \mathrm{Mg}, \mathrm{Zn}, \mathrm{Fe}, \mathrm{Mn}, \mathrm{Cu}$, e B.

$\mathrm{O}$ tratamento com $\mathrm{CO}_{2}$ na zona radicular afeta seletivamente a absorção dos minerais pelas plantas. Incrementa a concentração de $\mathrm{Ca}^{2+}$ e $\mathrm{Mg}^{2+}$ e diminui a concentração de $\mathrm{Mn}^{2+}$ e $\mathrm{Cl}^{-}$, enquanto que a concentração de $\mathrm{K}^{+}$não é alterada (Arteca et al., 1979).

Furlan et al. (2001) avaliaram os efeitos da aplicação de $\mathrm{CO}_{2}$ via água de irrigação na produtividade e qualidade de alface cultivada em ambiente protegido, aplicando $50 \mathrm{~L} \mathrm{~m}^{-2}$ dia $^{-1}$ de $\mathrm{CO}_{2}$ durante 30 dias. Conseguiram aumento de área foliar e peso de matéria seca de $27 \%$, e o rendimento de cabeças aumentou em até $28,8 \%$. 
O resultado do incremento no rendimento é conseqüência dos efeitos combinados do limitado enriquecimento atmosférico de $\mathrm{CO}_{2}$ e as modificações do ambiente do solo em função à disponibilidade de nutrientes (Novero et al., 1991).

Para muitas espécies é difícil estabelecer concentrações ótimas de $\mathrm{CO}_{2}$, pela escassez de dados na literatura (Furlan et al., 2001).

Com o propósito de explicar o efeito de incremento da concentração de $\mathrm{CO}_{2}$ atmosférico no rendimento das culturas, Kimball, (1983) realizou mais de 430 observações em diferentes culturas, sendo que 37 espécies apresentaram um aumento na produção com o enriquecimento de $\mathrm{CO}_{2}$, tendo destaque o algodão que apresentou a maior média. Concluiu-se que o algodão é uma das culturas que melhor responde ao enriquecimento de $\mathrm{CO}_{2}$. Com base nesta informação Mauney \& Hendrix (1988) conduziram um ensaio com algodão aplicando água carbonatada sobre a cultura em ambiente protegido. Foi observado um incremento no crescimento das plantas, nível de fotossíntese e absorção de Zn e $\mathrm{Mn}$, e concluíram que a resposta do incremento foi o resultado indireto do aumento de absorção de nutrientes devido à mudança de $\mathrm{pH}$ produzido pela aplicação de água carbonatada.

A fixação de dióxido de carbono por raízes de plantas foi reportada pela primeira vez em cevada e foi proposto que o $\mathrm{CO}_{2}$ fixado nas raízes poderia ser translocado pelas folhas. A fixação de carbono também tem sido reportada em cebola e soja (Arteca \& Poovaiah, 1982a). Nos anos 80 foi estabelecido que as raízes de soja e os nódulos possuem um sistema ativo para fixação de $\mathrm{CO}_{2}$ (Coker \& Schubert, 1981).

Segundo Mortensen (1987), a concentração ótima de $\mathrm{CO}_{2}$ para o crescimento da maioria das espécies varia entre 600 e $900 \mathrm{mmol} \mathrm{CO}_{2} \mathrm{~mol}^{-1}$ de ar, observando-se injúnias acima de $1.000 \mathrm{mmol} \mathrm{CO}_{2} \mathrm{~mol}^{-1}$ de ar. 
Arteca et al. (1979), procurando resposta das plantas à aplicação de $\mathrm{CO}_{2}$, trabalharam com planta de batata (Solanum tuberosum L. var. Russet Burbank) e aplicaram $\mathrm{CO}_{2}$ ao sistema radicular durante 12 horas. Após dois dias da aplicação verificaram que as plantas apresentaram um incremento de matéria seca, enquanto que 3 - 6 semanas após aplicação, apresentaram aumento na tuberização. Além disso, houve aumento no comprimento de estolão, número de tubérculos por estolão e peso seco total. Comprovaram também que plantas tratadas com $\mathrm{CO}_{2}$ aumentam a concentração dos ácidos málico e cítrico, assim, como os cátions $\mathrm{Mg}^{+2}$ e $\mathrm{Ca}^{+2}$, tendo o sistema radicular respondido melhor à aplicação de $\mathrm{CO}_{2}$ que a parte aérea.

O tomate é uma das poucas espécies que apresenta um decréscimo de resposta à aplicação suplementar de $\mathrm{CO}_{2}$ sob enriquecimento contínuo e por longo tempo (Novero et al., 1991).

Hartz \& Holt (1991), conduziram experimentos em Irvine (Califórnia) com objetivo de determinar os efeitos do enriquecimento de $\mathrm{CO}_{2}$ via água de irrigação sobre tomate e pepino. Utilizaram as doses de $0 ; 0,5$; e $1,0 \mathrm{~g} \mathrm{~L}^{-1}$ de $\mathrm{CO}_{2} \mathrm{e}$ observaram que os rendimentos decresceram linearmente com o aumento da doses de $\mathrm{CO}_{2}$. Os decrementos de rendimento foram relacionados ao uso de mulch de plástico que aumentou a concentração de $\mathrm{CO}_{2}$ na atmosfera do solo, o que pode ter um efeito tóxico.

Cramer et al. (2001), na Africa do Sul, elevando a concentração de carbono inorgânico dissolvido, buscavam incrementos de rendimento e qualidade de tomate. Com 5000 ppm de $\mathrm{CO}_{2}$ conseguiram um incremento de 7\% em média do peso de frutos comerciais, mas não houve um efeito significativo no rendimento $e$ qualidade com respeito ao controle.

Donnelly et al. (2001c) estudaram os efeitos de incremento de $\mathrm{CO}_{2} \mathrm{e} \mathrm{O}_{3}$ na qualidade de tubérculos de batata cv. Bintje. Utilizaram concentrações de 550 e $680 \mu \mathrm{mol} \mathrm{mol}{ }^{-1}$ de $\mathrm{CO}_{2}$, mais a concentração de $\mathrm{CO}_{2}$ atmosférico $\left(370 \mu \mathrm{mol} \mathrm{mol}{ }^{-}\right.$ 
$\left.{ }^{1}\right)$. Concluíram que com o incremento de $\mathrm{CO}_{2}$ houve um aumento no conteúdo de amido e na viscosidade. No entanto, houve diminuição do conteúdo de glicoalcaloide, ácido cítrico e nitrogênio nos tubérculos.

Field et al. (1992) reportaram que elevando a concentração de $\mathrm{CO}_{2}$ houve incrementos tanto de biomassa como de reservas de carbohidratos, enquanto que diminuiu a concentração de nitrogênio nos tecidos.

A liberação direta de $\mathrm{CO}_{2}$ em busca do enriquecimento atmosférico não é benéfica sob condições de campo (Novero et al., 1991).

A campo aberto, o uso de cobertura sobre as linhas de gotejamento poderia incrementar o potencial do enriquecimento de $\mathrm{CO}_{2}$, quando é aplicada água carbonatada pelo sistema (Moore, 1990).

Em estudos realizados por Baron \& Gorski (1986) com berinjela, foi encontrado um incremento significativo na área foliar e na matéria seca quando estas foram cultivadas em condições de dias longos, temperatura alta e com $0,03 \%$ de $\mathrm{CO}_{2}$. Sob condições de dias curtos e baixo nível de luz, com $15 \%$ de $\mathrm{CO}_{2}$, houve redução na área foliar e na matéria seca.

Diferentes espécies de plantas reagem de forma distinta em ambientes com alta concentração de dióxido de carbono. O crescimento da raiz de Pisum sativum, Vicia faba, Phaseolus vulgaris e Helianthus annum foram completamente inibidos pela alta concentração de $\mathrm{CO}_{2}$, ao passo que Avena sativa e Hordeum vulgare não foram afetados. Plantas de Solanum tuberosum particularmente são bem adaptadas ao enriquecimento de $\mathrm{CO}_{2}$ na zona da raiz devido à habilidade para tolerar altas concentrações de $\mathrm{CO}_{2}$ (Stolwijk \& Thimann, 1957; Arteca et al., 1979).

A concentração atual de $\mathrm{CO}_{2}$ apresenta-se limitante para a fotossíntese em espécies $\mathrm{C} 3$ como a batata, que a $700 \mathrm{ppm}$ de $\mathrm{CO}_{2}$ poderia aumentar o rendimento em 20-30\%, dependendo do ciclo das variedades, tal como tem demonstrado Schapendonk et al. (1995), mediante a utilização de modelos de 
simulação. De qualquer forma, como a batata é uma cultura que é cultivada ao ar livre, este efeito benéfico só poderia ser registrado em caso de que a concentração de $\mathrm{CO}_{2}$ na atmosfera alcançasse ditos níveis no futuro, ou se for cultivada em casas de vegetação com atmosfera enriquecida com $\mathrm{CO}_{2}$.

A sensibilidade das trocas de $\mathrm{CO}_{2}$ à deficiência hídrica é uma característica da espécie, sendo porém adaptável. Esta sensibilidade depende ainda da idade da planta, da posição de ramos e folhas na copa da árvore e da umidade do solo (Larcher, 1995).

As plantas submetidas a estresse hídrico freqüente respondem melhor às maiores concentrações de dióxido de carbono (Ham et al., 1995). O aumento da concentração de dióxido de carbono causa fechamento parcial dos estômatos, implicando em redução na transpiração (Cure \& Acock, 1986; Faquhar et al., 1978). Assim há aumento da taxa de crescimento, com produção de maior quantidade de matéria vegetativa e aumento na área foliar (Morisom \& Gifford, 1984). Mesmo em condições de luminosidade inadequada e deficiência hídrica, a taxa de crescimento das plantas é aumentada em ambientes com alta concentração de dióxido de carbono, que ocorre devido ao fechamento dos estômatos e maior expansão do sistema radicular, possibilitando a exploração de um maior volume de solo (Curtis et al., 1990).

\subsection{Dióxido de carbono e efeitos evolutivos}

$\mathrm{O}$ enriquecimento de $\mathrm{CO}_{2}$ atmosférico altera a quantidade e qualidade da produção das plantas, mas os efeitos fisiológicos e sua variação genotípica são pouco conhecidos (Lindroth et al., 2001).

Durante a última década, vêm causando impacto pesquisas com enriquecimento de $\mathrm{CO}_{2}$ atmosférico em plantas, elevando-se em forma exponencial, de modo que os trabalhos foram realizados com ênfase na avaliação 
dos efeitos de $\mathrm{CO}_{2}$ nos extremos da continuidade ecológica. A nível fisiológico, as pesquisas foram focalizadas no processo metabólico e no crescimento das plantas individuais; no nível de ecossistema, as pesquisas enfatizaram o ciclo de carbono e a captura do mesmo (Lindroth et al., 2001). Este é particularmente uma legítima resposta evolutiva das plantas ao incremento de $\mathrm{CO}_{2}$ (Ward \& Strain, 1999). Efeitos evolutivos podem ser determinados pela variação genética numa população, e pela resposta de aptidão relacionado aos traços da mudança do meio ambiente. Podem surgir diretamente mudanças na estrutura genética das populações, devido aos diferentes efeitos de $\mathrm{CO}_{2}$ na produtividade das plantas. $\mathrm{O}$ enriquecimento de $\mathrm{CO}_{2}$ tende a aumentar a produção e o crescimento das plantas (Kimball, 1983; Saxe et al., 1998), embora seja pouco conhecida a variação intraespecífica com semelhante resposta. Alternativamente, mudanças na estrutura genética podem surgir indiretamente, devido ao efeito diferencial do $\mathrm{CO}_{2}$ no aproveitamento ou na interação competitiva (Bazzaz et al., 1995).

Os efeitos da evolução poderiam ser ceterminados pela magnitude da variação genética em uma população, e pela resposta da aptidão relacionado æ̀ características de mudança do meio ambiente (Lindroth et al., 2001).

$\mathrm{O}$ enriquecimento de $\mathrm{CO}_{2}$ pode alterar a capacidade defensiva (Peñuelas \& Estiarte, 1998) ou competitiva (Potvin \& Vasseur, 1997) das plantas. Porém existe pouca informação de respostas com respeito ao potencial da variação intra-específica. 


\section{MATERIAL E MÉTODOS}

Este trabalho foi desenvolvido em três etapas, sendo uma preliminar em casa de vegetação e duas em condições de campo.

\subsection{Estudo preliminar}

\subsubsection{Ponto de saturação de luz e ponto de compensação de $\mathrm{CO}_{2}$}

Foi realizado um estudo do ponto de saturação de luz e do ponto de compensação de $\mathrm{CO}_{2}$ para a determinação das doses dos tratamentos de $\mathrm{CO}_{2}$, utilizando-se plantas de batata 'Itararé', cultivadas em casa de vegetação e, com o auxilio de um aparelho medidor de $\mathrm{CO}_{2}$ denominado IRGA (Infra Red Gas Analyzer) modelo L16400 fabricado pela LI-COR, Nebraska/USA.

\subsubsection{Principio de funcionamento do aparelho IRGA}

É um sistema portátil que permite, por meio de medidas das trocas gasosas, quantificar a taxa de consumo de $\mathrm{CO}_{2}$ de um tecido foliar. $\mathrm{O}$ aparelho é composto de um console e de uma câmara ventilada de $6 \mathrm{~cm}^{2}$, onde é colocada a folha a ser analisada. O console está composto por uma bomba de sucção, reservatório de ar, válvula de ajuste, medidor de fluxo de massa de ar, controlador interno de fluxo e um microprocessador, que possui a função de processar e armazenar dados. Na câmara ventilada está o ventilador, o sensor de $\mathrm{CO}_{2}$ e de umidade, um termopar de referência e outro que entra em contato com a face inferior da folha (Long \& Hallgren, 1993), (Figura 1). 
O aparelho funciona com uma fonte que emite ondas de comprimento no infravermelho através de uma célula de análise, onde simultaneamente é transportado o gás proveniente da amostra em estudo, e paralelamente existe uma outra célula chamada de referência que permanece transportando moléculas de $\mathrm{CO}_{2}$ com concentração conhecida. As moléculas de $\mathrm{CO}_{2}$ absorvem ondas de luz infravermelho e, um detector, em posição oposta à fonte de emissão, compara a quantidade de radiação que passa por cada célula, registrando a diferença. $A$ taxa de assimilação de $\mathrm{CO}_{2}$ é expressa como a quantidade de $\mathrm{CO}_{2}$ assimilado ou liberado por unidade de área foliar e tempo, cuja unidade é $\mu \mathrm{mol} \mathrm{CO}_{2} \mathrm{~m}^{-2} \mathrm{~s}^{-1}$ (Peet \& $\operatorname{Krizek}^{5}$ (1997) citado por Gomes, 2001).

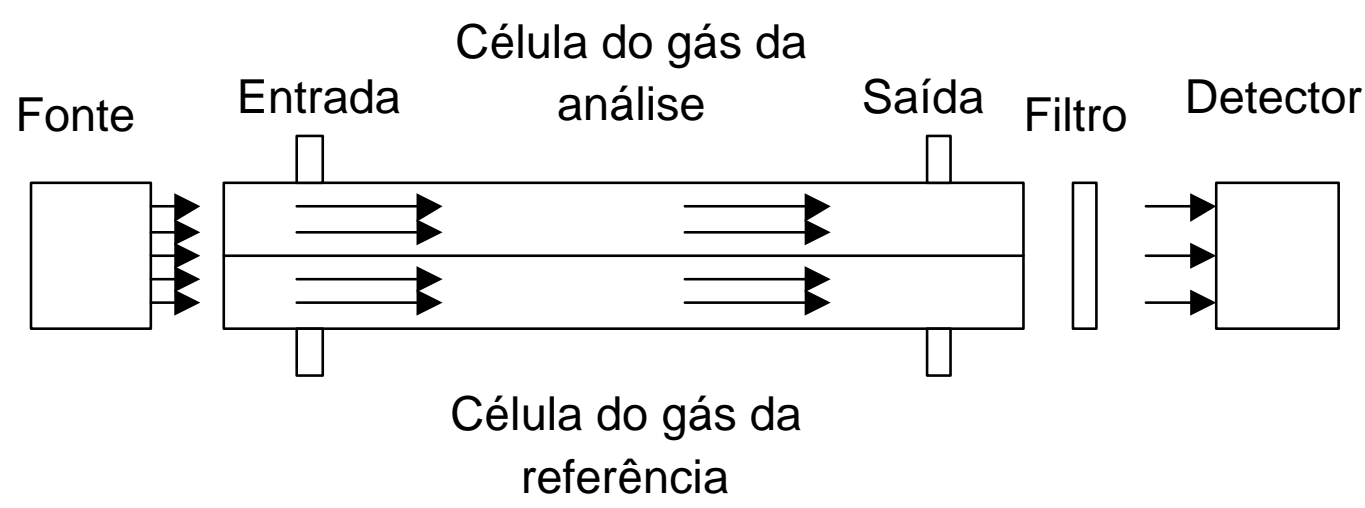

Figura 1 - Esquema do principio de funcionamento do IRGA

\subsubsection{Experimento preliminar}

Em dois de março de 2001 foram plantadas batatas-semente do cultivar Itararé em 10 vasos de plástico de $10 \mathrm{~L}$ de volume, colocando uma batata por vaso. Após o início do florescimento (47 dias após plantio) selecionou-se o folíolo final da quarta folha desenvolvida e começaram-se a realizar as leituras no

\footnotetext{
${ }^{5}$ PET, MM.; KRIZER, D.T. Carbon dioxide. In: LANGHANS, R.W.; TIBBITTS, T.W. Plant growth chamber handbook. Ames: lowa State University, 1997. cap.4, p.65-79.
} 
aparelho IRGA em 10 repetições de folhas e plantas diferentes para a elaboração das curvas de saturação lumínica e de compensação de $\mathrm{CO}_{2}$, (Figuras 2 e 3).

O primeiro a ser determinado foi o ponto de saturação de luz. Para este, foram programados, no aparelho, os valores de DFFFA (Densidade de Fluxo de Fótons Fotossintéticamente Ativos) correspondentes a 40, 200, 400, 600, 800, $1000,1200,1400$, e $1600 \mu \mathrm{mol}$ fótons $\mathrm{m}^{-2} \mathrm{~s}^{-1}$. Para cada valor indicado foi realizada a leitura dos valores de "A" (assimilação de $\mathrm{CO}_{2}$ ), sendo os mesmos calculados automaticamente pelo aparelho medidor, para os respectivos valores de fotossíntese, cuja unidade é $\mu \mathrm{mol} \mathrm{CO}_{2} \mathrm{~m}^{-2} \mathrm{~s}^{-1}$.

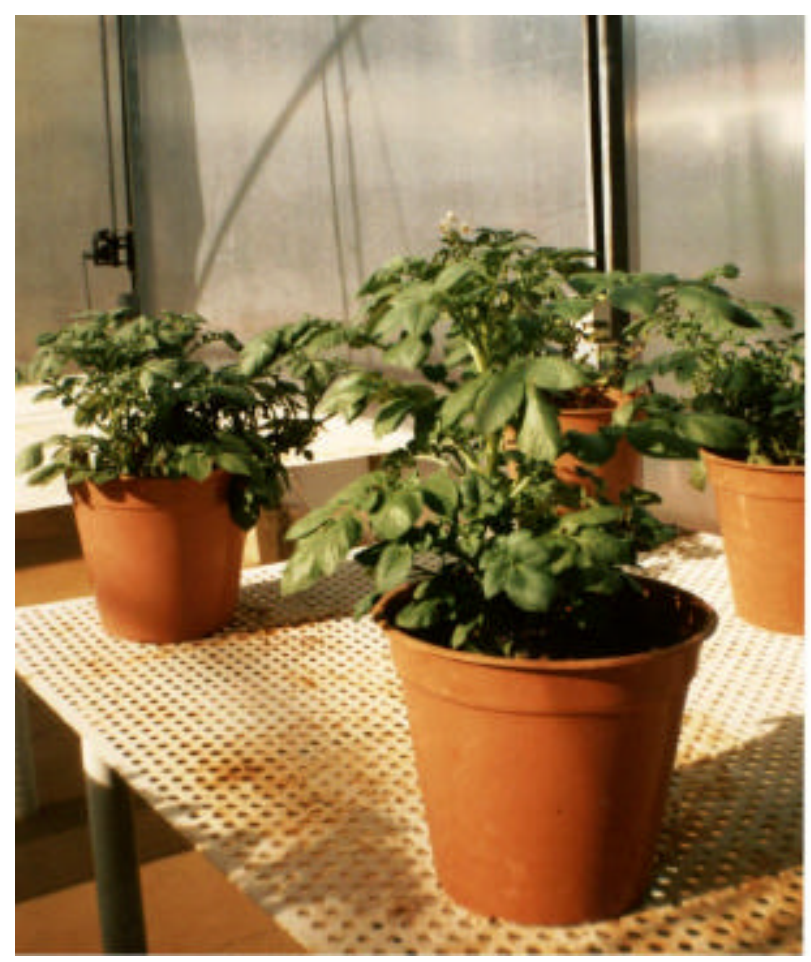

Figura 2 - Plantas de batata 'Itataré' cultivadas em casa de vegetação 


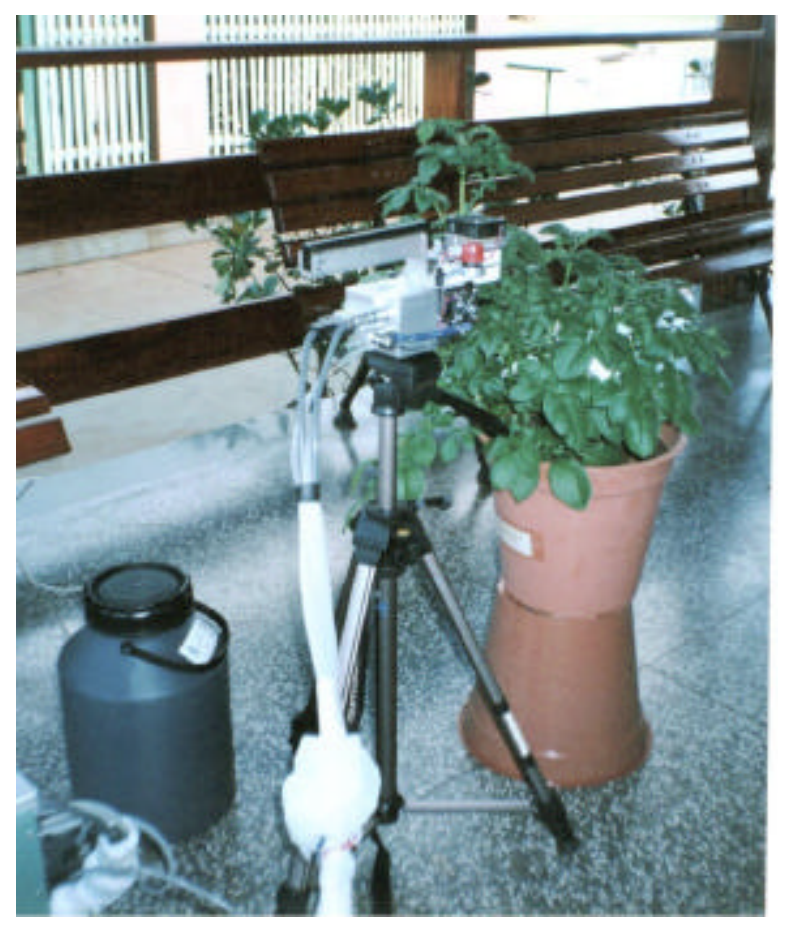

Figura 3 - Aparelho IRGA no momento da medição da taxa de assimilação de $\mathrm{CO}_{2}$

Programando-se 0 aparelho com 0 valor fixo de ponto de saturação lumínica encontrado, procedeu-se a determinação da curva de compensação de $\mathrm{CO}_{2}$. Para isto, utilizaram-se os valores de concentração de $\mathrm{CO}_{2}$ de 50, 200, 400, $600,800,1000,1200,1400$ e $1600 \mu \mathrm{mol} \mathrm{mol}^{-1}$ (ppm de $\mathrm{CO}_{2}$ ).

\subsection{Caracterização da área experimental a campo}

Foram conduzidos dois experimentos (Experimento I e Experimento II), um no período de 19 de julho a 31 de outubro de 2001, e outro de 25 de maio a 18 de setembro de 2002 na fazenda Areão, no campo experimental pertencente ao Departamento de Engenharia Rural da Escola Superior de Agricultura "Luiz de Queiroz" - Universidade de São Paulo, localizado no município de Piracicaba-SP, com altitude média de $576 \mathrm{~m}$, latitude de $22^{\circ} 42^{\prime} 30^{\prime \prime} \mathrm{S}$ e longitude $47^{\circ} 30^{\prime} 00^{\prime \prime} \mathrm{W}$. Segundo a classificação de Köppen (1948), o clima da região é do tipo CWA: 
subtropical úmido, com chuvas de verão, inverno seco, temperatura média $21,1^{\circ} \mathrm{C}$. A precipitação média anual é de $1247 \mathrm{~mm}$, a umidade relativa do ar é de $74 \%$, a velocidade média do vento é de $2,2 \mathrm{~m} \mathrm{~s}^{-1}$, com direção predominante E/SE (Ometto,1981). O solo é classificado como Terra Roxa Estruturada (Alfisol), série Luiz de Queiroz, apresentando declividade média de 5\%.

\subsection{Experimento I}

\subsubsection{Delineamento experimental}

O delineamento experimental utilizado foi o de blocos ao acaso, com 20 parcelas, ou seja, 5 tratamentos (T1=0; T2=205,2; T3=279,36; T4=353,52; $\mathrm{T} 5=427,68 \mathrm{~kg} \mathrm{ha}^{-1}$ de $\mathrm{CO}_{2}$, respectivamente) e 4 repetições.

A área foi dividida em 20 parcelas, com dimensões de 3,20 m de largura e $5,00 \mathrm{~m}$ de comprimento cada parcela, totalizando $320 \mathrm{~m}^{2}$, como mostrada na Figura 4.

O delineamento experimental para análise da variância das variáveis de número de folhas, número de estolões, área foliar, índice de área foliar, número de tubérculos, massa seca da parte aérea, massa seca de raízes, massa seca de tubérculos e relação parte aérea/raízes, foi o de blocos ao acaso, com parcelas subdivididas no tempo (split plot), com quatro repetições. As parcelas constaram as doses de $\mathrm{CO}_{2}$ e as subparcelas, as amostragens realizadas ao longo do experimento, em total de 5 . 


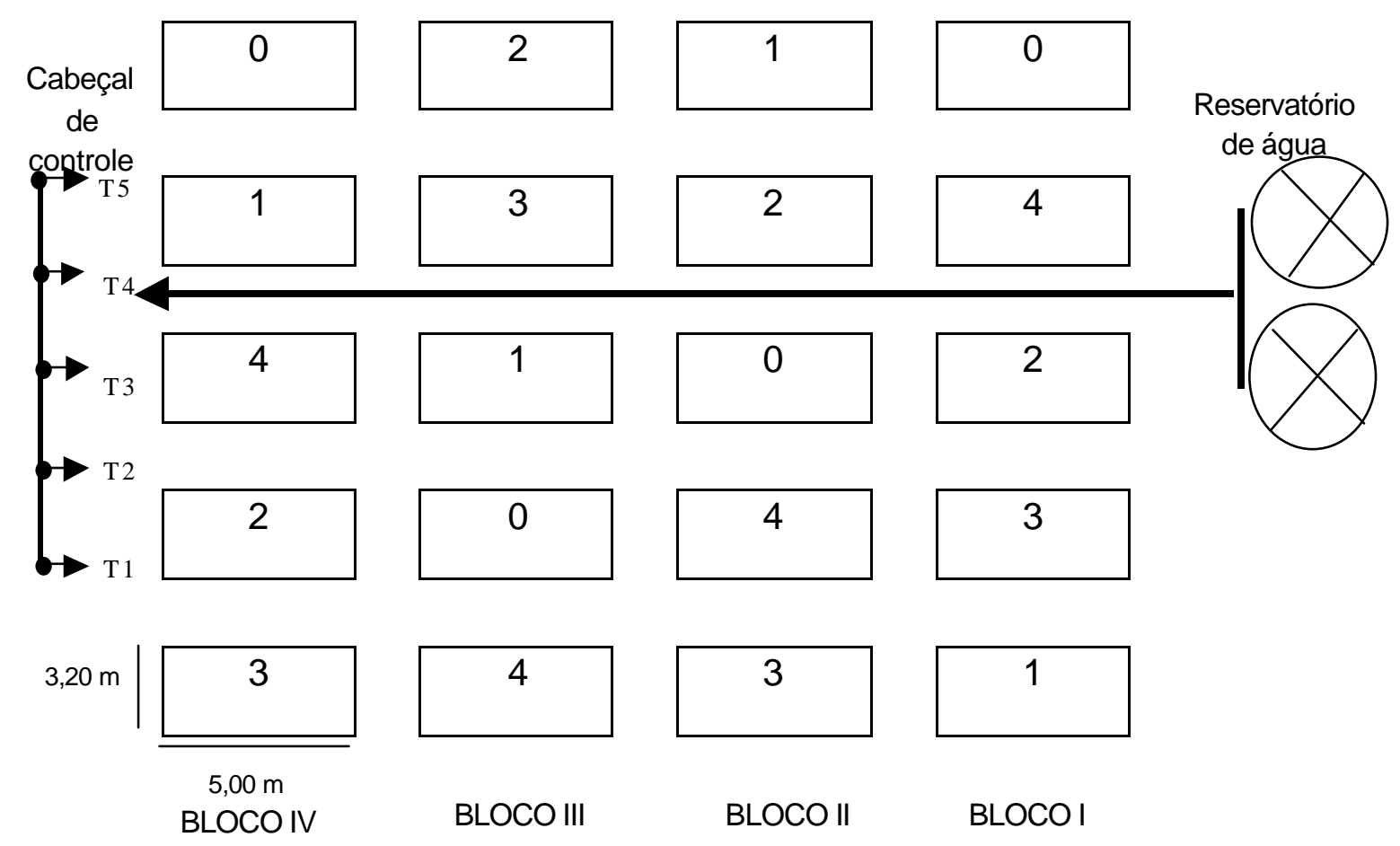

Figura 4 - Esquema do experimento I, mostrando a distribuição dos tratamentos (T1=0; T2=205,2; T3=279,36; T4=353,52; T5=427,68 $\mathrm{kg} \mathrm{ha}^{-1} \mathrm{de}$ $\left.\mathrm{CO}_{2}\right)$

O delineamento experimental para análise da variância das variáveis de produção total e classificação da produção, foi blocos ao acaso com quatro repetições, sendo que os blocos constaram das doses de $\mathrm{CO}_{2}$.

\subsubsection{Caracterização Física e Química do Solo}

Com a finalidade de se efetuar a adubação, realizou-se uma amostragem de solo à profundidade de $0-20 \mathrm{~cm}$ e $20-40 \mathrm{~cm}$, para a análise físico-química, cujos resultados são apresentados nas Tabelas 1, 2 e 3. 
Tabela 1. Análise granulométrica do solo do primeiro experimento. Piracicaba, SP. 2001

\begin{tabular}{ccccc}
\hline $\begin{array}{c}\text { Profundidade } \\
(\mathrm{cm})\end{array}$ & $\begin{array}{c}\text { Areia } \\
(\%)\end{array}$ & $\begin{array}{c}\text { Silte } \\
(\%)\end{array}$ & $\begin{array}{c}\text { Argila } \\
(\%)\end{array}$ & $\begin{array}{c}\text { Classe de } \\
\text { Textura }\end{array}$ \\
\hline $0-20$ & 14 & 33 & 53 & argiloso \\
$20-40$ & 16 & 17 & 67 & argiloso \\
\hline
\end{tabular}

Tabela 2. Análise química do solo do primeiro experimento. Piracicaba, SP. 2001

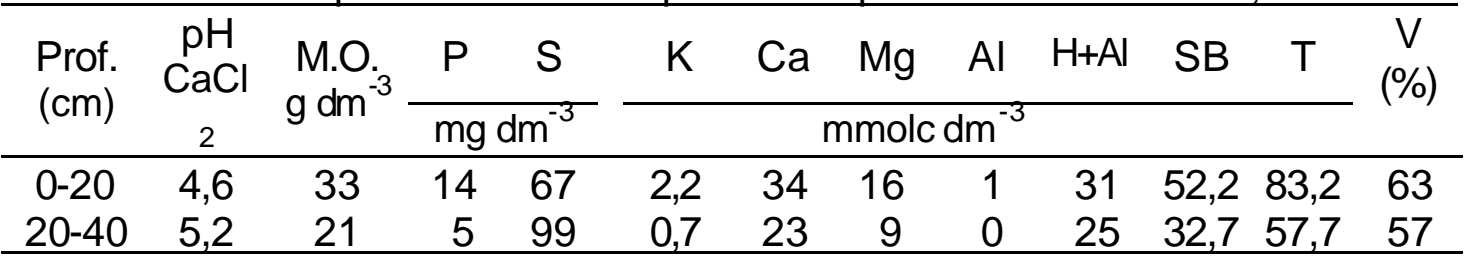

Tabela 3. Análise de micronutrientes do solo do primeiro experimento. Piracicaba, SP. 2001

\begin{tabular}{|c|c|c|c|c|c|}
\hline \multirow{2}{*}{$\begin{array}{l}\text { Profundidade } \\
\text { (cm) }\end{array}$} & $B$ & $\mathrm{Cu}$ & $\mathrm{Fe}$ & $\mathrm{Mn}$ & $\mathrm{Zn}$ \\
\hline & \multicolumn{5}{|c|}{$\mathrm{mg} \mathrm{dm}^{-3}$} \\
\hline $0-20$ & 0,37 & 7,4 & 28 & 86,0 & 5,7 \\
\hline $20-40$ & 0,40 & 3.1 & 10 & 15.8 & 1,2 \\
\hline
\end{tabular}

\subsubsection{Preparo do solo e plantio}

O preparo do solo consistiu em duas arações e uma gradagem com antecedência de um mês do plantio, seguido de uma gradagem na época do plantio. Anteriormente à aração, efetuou-se uma correção prévia com gesso agrícola na dosagem de $1 \mathrm{t} \mathrm{ha}^{-1}$ por recomendação do laboratório de análise do Departamento de solos e Nutrição de Plantas.

Por ocasião do plantio, foi distribuído adubo no fundo do sulco baseandose na análise do solo. A quantidade de adubo aplicado foi de $600 \mathrm{Kg} \mathrm{ha}^{-1}$ de $\mathrm{N}$, $\mathrm{P}_{2} \mathrm{O}_{5}$ e $\mathrm{K}_{2} \mathrm{O}$, com adubo de formulação comercial 10 - 20 - 20, e com 1,6 kg ha-1 de Boro. Em seguida o adubo foi misturado ao solo a fim de evitar o contato direto com a batata-semente. 
O plantio foi realizado em dezenove de julho de 2001, colocando-se os tubérculos certificados de batata-semente, fornecidos pelo Departamento de Raízes e Tubérculos do IAC (Instituto Agronômico de Campinas), com massa média de $50 \mathrm{~g}$, em sulcos espaçados de $80 \mathrm{~cm}$ e com $15 \mathrm{~cm}$ de profundidade. Depois distribuídos a cada $40 \mathrm{~cm}$ nos sulcos, os tubérculos foram cobertos com solo úmido.

\subsubsection{Manejo de irrigação e aplicação de $\mathrm{CO}_{2}$}

O suprimento de água para o sistema de irrigação foi composto por duas caixas de fibra de vidro com capacidade de $1000 \mathrm{~L}$ cada, conectadas entre si, e o nível da água regulado por um bóia, e uma motobomba KSB HIDROBLOC C 500 de $0,5 \mathrm{HP}$ de potência, com vazão máxima de $7,8 \mathrm{~m}^{3} \mathrm{~h}^{-1}$ e altura manométrica máxima de recalque de $70 \mathrm{kPa}$ (Figura 5). Conectada à motobomba foi instalada uma tubulação de PVC rígido de $20 \mathrm{~mm}$, a esta colocourse um filtro de tela de 120 Mesh, seguido de um registro esférico e um hidrômetro, para o monitoramento do volume de água aplicado. Em seguida, conectou-se ao hidrômetro uma tubulação de PVC rígido de $20 \mathrm{~mm}$, sendo a mesma prolongada até a cabeceira da área experimental. Antes do sistema de cabeçal colocaram-se uma válvula reguladora de pressão e um manômetro (Figura 6).

A partir do cabeçal, a água foi conduzida até as parcelas através de tubulações de polietileno flexível preto de $20 \mathrm{~mm}$ de diâmetro. $\mathrm{Na}$ entrada de cada parcela a tubulação de $20 \mathrm{~mm}$ foi conectada a uma tubulação de PVC rígido de $32 \mathrm{~mm}$ de diâmetro, perfurada lateralmente a cada $0,80 \mathrm{~m}$ para a colocação de um anel vedante e um conector inicial de rosca. A este conectou-se os tubogotejadores Queen gil com as seguintes características: diâmetro interno de $16,5 \mathrm{~mm}$, espessura da parede de $0,2 \mathrm{~mm}$, pressão recomendada de 50 a 70 
$\mathrm{kPa}$, e a vazão nominal de $4 \mathrm{~L} \mathrm{~m}^{-1} \mathrm{~h}^{-1}$, com espaçamento entre os gotejadores de $0,1 \mathrm{~m}$. Os tubogotejadores foram colocados na superfície de cada sulco.

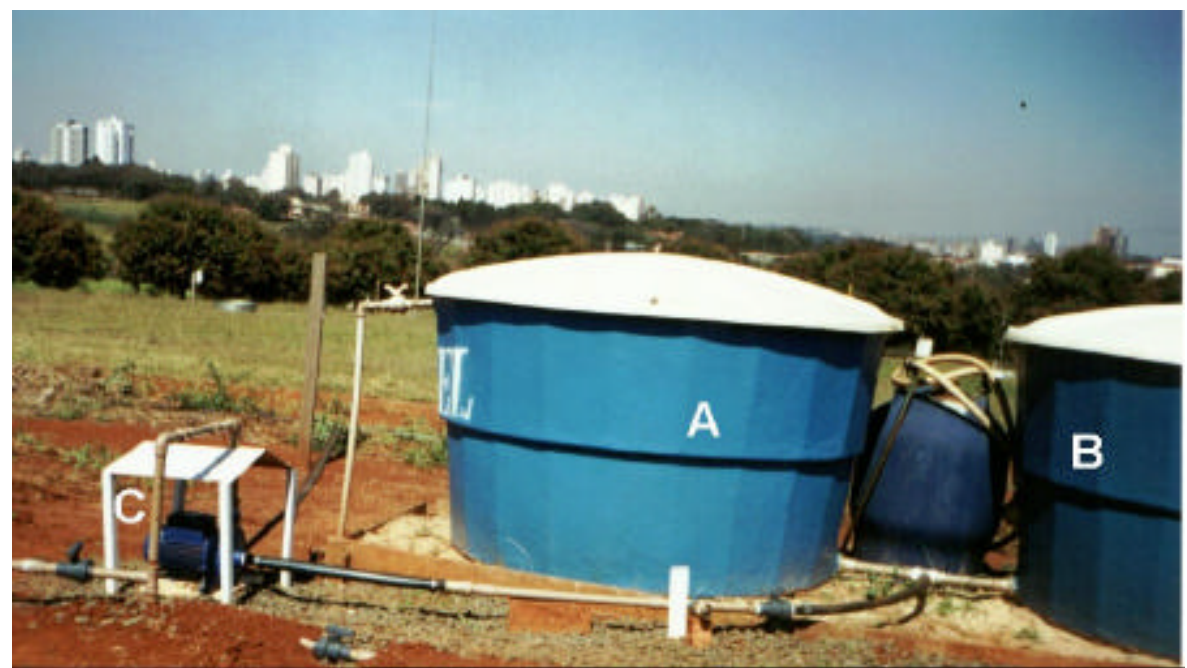

Figura 5-Reservatórios de água (A e B) e motobomba (C)

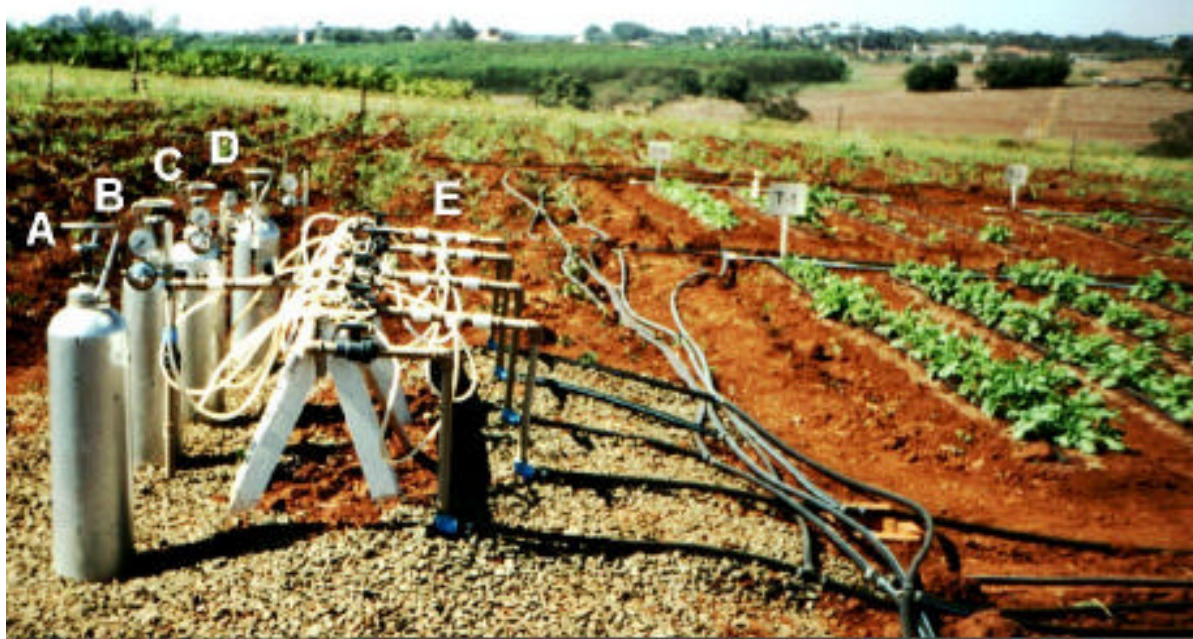

Figura 6 - Sistema de cabeçal, mostrando os quatro cilindros contendo $\mathrm{CO}_{2}$ $\left(A, B, C\right.$ e D) e injetor de $\mathrm{CO}_{2}(E)$

As irrigações foram feitas diariamente pela manhã entre 9 e 11 horas. A lâmina inicial de irrigação foi calculada pela capacidade máxima de armazenamento de água no solo, com o auxílio da Tabela 4. 
Tabela 4. Potencial matricial e umidade volumétrica do solo observados e ajustados pela curva de retenção para as profundidades de 10 e $30 \mathrm{~cm}$

\begin{tabular}{ccccc}
\hline \multirow{2}{*}{$\begin{array}{c}\text { Potencial Matricial } \\
(\mathrm{kPa})\end{array}$} & \multicolumn{2}{c}{$\begin{array}{c}\text { Umidade }(10 \mathrm{~cm}) \\
\left(\mathrm{cm}^{3} \mathrm{~cm}^{-3}\right)\end{array}$} & \multicolumn{2}{c}{$\begin{array}{c}\text { Umidade }(30 \mathrm{~cm}) \\
\left(\mathrm{cm}^{3} \mathrm{~cm}^{-3}\right)\end{array}$} \\
& Observada & Ajustada & Observada & Ajustada \\
\hline 0 & 0,5410 & 0,5420 & 0,5420 & 0,5253 \\
1 & 0,4583 & 0,4538 & 0,4865 & 0,4840 \\
2 & 0,4143 & 0,4213 & 0,4613 & 0,4567 \\
4 & 0,4032 & 0,3972 & 0,4530 & 0,4489 \\
10 & 0,3671 & 0,3692 & 0,4259 & 0,4260 \\
30 & 0,3426 & 0,3430 & 0,4009 & 0,4012 \\
50 & 0,3344 & 0,3330 & 0,3882 & 0,3908 \\
100 & 0,3230 & 0,3213 & 0,3788 & 0,3781 \\
500 & 0,3018 & 0,3008 & 0,3543 & 0,3536 \\
1500 & 0,2911 & 0,2909 & 0,3401 & 0,3403 \\
\hline
\end{tabular}

Fonte: Ramos (1998)

Para o manejo da irrigação utilizou-se a Equação 1, substituindo-se na mesma as seguintes características do solo: umidade de capacidade de campo com base em volume de $0,3671 \mathrm{~cm}^{3} \mathrm{~cm}^{-3}$, umidade de ponto de murcha permanente com base em volume de $0,2911 \mathrm{~cm}^{3} \mathrm{~cm}^{-3}$, obtidas da Tabela 4 elaborado por Ramos (1998); fator $f$ da cultura de 0,4 e; profundidade efetiva de raízes de $20 \mathrm{~cm}$; resultando na disponibilidade real de água de 6,168 $\mathrm{mm}$.

$$
\text { DRA }=(\text { ècc }- \text { èpmp }) f z 10
$$

em que:

DRA - Disponibilidade real de água, $\mathrm{mm}$;

$\theta c c$ - Umidade à capacidade de campo com base em volume, $\mathrm{cm}^{3} \mathrm{~cm}^{-3}$;

Өpmp - Umidade no ponto de murcha permanente com base em volume, $\mathrm{cm}^{3} \mathrm{~cm}^{-3}$;

f - Fator da cultura, adimensional; e

z $\quad$ - Profundidade efetiva do sistema radicular, $\mathrm{cm}$.

Para determinação de evapotranspiração da cultura (ETc) Equação 2), utilizaram-se os valores de Kc, citados por Doorenbos \& Kassam (1979) para 
batata que variaram de 0,45 a 1,10 para um ciclo de 110 dias e, a constante Kp de tanque classe A igual a 0,75, descrito por Doorenbos \& Pruitt (1977)

A evaporação do tanque classe $A$ foi corrigida pelos coeficientes de cultivo descritos por Doorembos \& Kassam (1979) e pelo coeficiente do tanque classe A $(\mathrm{Kp}=0,75)$ para a obtenção da evapotranspiração da cultura.

$\mathrm{ETc}=\mathrm{ECAKpKc}$

em que:

ETc - Evapotranspiração da cultura, $\mathrm{mm} \mathrm{dia}^{-1}$;

ECA - Evaporação do tanque classe $\mathrm{A}, \mathrm{mm} \mathrm{dia}^{-1}$;

$\mathrm{Kp} \mathrm{-} \mathrm{Coeficiente} \mathrm{do} \mathrm{tanque} \mathrm{classe} \mathrm{A,} \mathrm{adimensional;} \mathrm{e}$

Kc - Coeficiente da cultura, adimensional.

A irrigação foi baseada na lâmina evaporada no tanque classe $A$, sendo a umidade do solo monitorada por três baterias de três tensiômetros posicionados, o primeiro a $10 \mathrm{~cm}$ de distância da planta e os demais espaçados de $5 \mathrm{~cm}$ entre si (Figura 7). As profundidades instaladas dos mesmos foram de 7,5; 22,5; e 37,5 $\mathrm{cm}$, respectivamente.

Foram realizadas as leituras dos tensiômetros diariamente, a fim de manter a tensão do solo inferior a $50 \mathrm{kPa}$. Durante a primeira fase (do plantio a emergência) foram monitoradas com os tensiômetros a $7,5 \mathrm{~cm}$ de profundidade; a partir do final da primeira fase até a colheita foram monitoradas com os tensiômetros as profundidades de $22,5 \mathrm{~cm}$. Os tensiômetros localizados a profundidade de $37,5 \mathrm{~cm}$ foram utilizados para controlar possível aplicação excessiva da água ou eventual contribuição do lençol freático. 


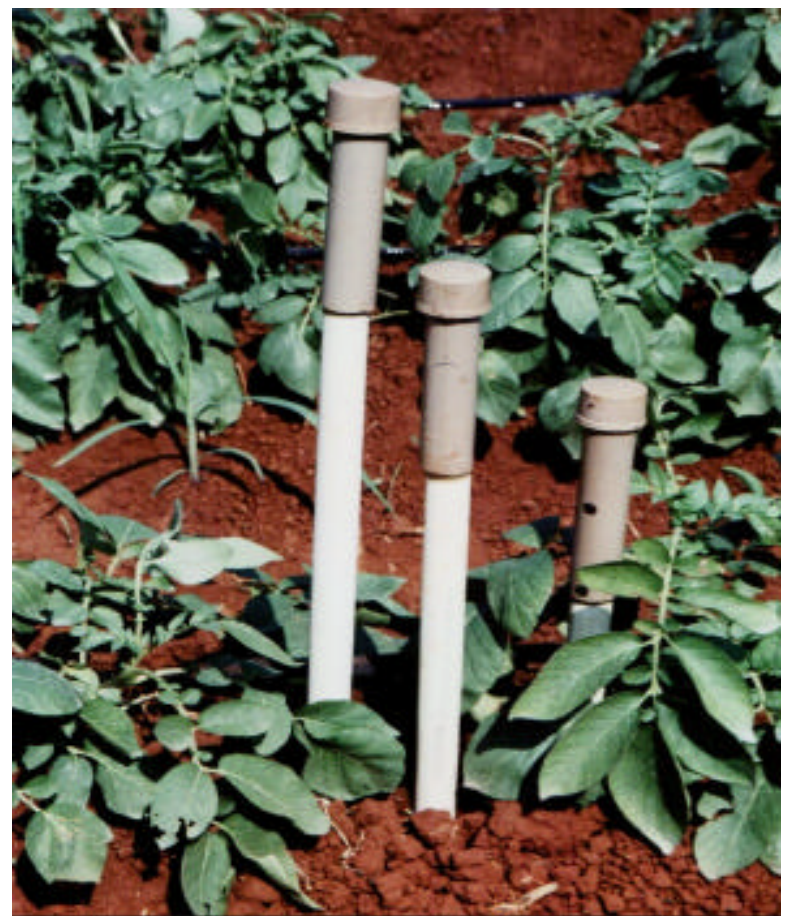

Figura 7 - Bateria de tensiômetros instalados a 7,5; 22,5; e $37,5 \mathrm{~cm}$ de profundidade, respectivamente

O tempo de irrigação correspondente à evapotranspiração da cultura foi determinado pela Equação 3.

$$
\mathrm{TI}=\frac{60 \mathrm{ETc} \mathrm{A}}{\mathrm{Q}}
$$

em que:

$\mathrm{TI} \quad$ - Tempo de irrigação, min;

A - Área da parcela, $\mathrm{m}^{2} ; \mathrm{e}$

Q - Vazão derivada à parcela, $\mathrm{L} \mathrm{h}^{-1}$.

O sistema de aplicação de $\mathrm{CO}_{2}$ funcionou simultaneamente ao sistema de irrigação e foi composto de 4 cilindros de dióxido de carbono de alta pressão com 15,1 L de capacidade, equipados com válvulas para quantificar a dosagem de $\mathrm{CO}_{2}$ a ser liberada dos cilindros, conectores de cobre, manômetros e injetores para introduzir o $\mathrm{CO}_{2}$ na água de irrigação. Como a pressão de injeção de $\mathrm{CO}_{2}$ 
do cilindro foi de $50 \mathrm{kPa}$ e superior à do sistema de irrigação no ponto de injeção (40 kPa), por diferença de pressão $\mathrm{O}^{\mathrm{CO}_{2}}$ ingressou nas linhas de irrigação chegando às parcelas que receberam o respectivo tratamento.

A aplicação da mistura água- $\mathrm{CO}_{2}$ foi realizada a partir do sétimo dia após a emergência - DAE (13/08/01) e a cada vez que era realizada a irrigação.

As concentrações de $\mathrm{CO}_{2}$ foram definidas com base no ponto de saturação de $\mathrm{CO}_{2}$ para a batateira determinada na primeira fase, e foram: $\mathrm{T} 1=0$; $\mathrm{T} 2=205,20 ; \mathrm{T} 3=279,36 ; \mathrm{T} 4=353,52 ; \mathrm{T} 5=427,68 \mathrm{Kg} \mathrm{ha}^{-1}$ de $\mathrm{CO}_{2}$, respectivamente.

O tempo de aplicação foi de 20 minutos para cada tratamento. A calibração de cada cilindro foi realizada baseado no tempo de preenchimento do $\mathrm{CO}_{2}$ (Tabela 5) em uma proveta de vidro com capacidade de $100 \mathrm{~mL}$, a qual se encontrava submergida em um balde com água.

Tabela 5. Tempo calculado para calibração de cada tratamento de $\mathrm{CO}_{2}$

\begin{tabular}{|c|c|c|c|c|c|}
\hline Tratamento & $\begin{array}{l}\Delta \mathrm{CO}_{2} \\
(\mathrm{ppm})\end{array}$ & $\begin{array}{c}\text { Volume a } \\
\text { aplicar } \\
\left(\mathrm{cm}^{3} \mathrm{CO}_{2}\right. \\
\left.\text { canteiro }^{-1} \mathrm{dia}^{-1}\right)\end{array}$ & $\begin{array}{c}\text { Peso a } \\
\text { aplicar } \\
\left(\mathrm{g} \mathrm{CO}_{2} \mathrm{dia}^{-1}\right)\end{array}$ & $\begin{array}{l}\text { Vazão de } \mathrm{CO}_{2} \\
\text { em } 4 \text { canteiros } \\
\quad\left(L \text { min }^{-1}\right)\end{array}$ & $\begin{array}{c}\text { Tempo para } \\
\text { preencher a } \\
\text { proveta de } \\
100 \mathrm{~mL}(\mathrm{~s})\end{array}$ \\
\hline $\mathrm{T} 1$ & 0 & 0 & 0 & 0 & 0 \\
\hline T2 & 210 & 1680 & 3,3 & 0,336 & 17,9 \\
\hline T3 & 420 & 3360 & 6,6 & 0,672 & 8,93 \\
\hline T4 & 630 & 5040 & 9,9 & 1,008 & 5,95 \\
\hline T5 & 840 & 6720 & 13,2 & 1,344 & 4,46 \\
\hline
\end{tabular}

\subsubsection{Uniformidade de irrigação}

Para a avaliação de uniformidade foi utilizado o método proposto por Keller e Karmeli (1975), que recomendam a obtenção das vazões em quatro pontos ao longo da linha lateral, ou seja, o gotejador que se encontra, no inicio, a 1/3, a 2/3 e no final do comprimento da linha lateral. Para essa avaliação utilizaram-se as Equações 4 e 5 indicadas por Parra (2001). 
$\mathrm{U}=100(1-\mathrm{CV})$

em que:

U $\quad$ - Coeficiente de uniformidade de descarga, \%.

CV - Coeficiente de variação estatístico das descargas dos emissores, adimensional.

$\mathrm{CV}=\left(\frac{\mathrm{s}}{\overline{\mathrm{x}}}\right)$

em que:

$\mathrm{S} \quad$ - Desvio padrão das descargas dos emissores, $\mathrm{L} \mathrm{h}^{-1} ; \mathrm{e}$

$\bar{X} \quad$ - Média das descargas dos emissores, $\mathrm{L} \mathrm{h}^{-1}$.

\subsubsection{Parâmetros avaliados}

Efetuaram-se cinco avaliações durante o experimento, extraindo-se duas plantas laterais de cada parcela, em períodos de 14 dias, iniciando-se em vinte de agosto de 2001 aos 14 dias após emergência (DAE), correspondente aos 7 dias após início de aplicação de $\mathrm{CO}_{2}$. As medições realizadas foram: número de folhas, área foliar, número de estolões, número de tubérculos e massa seca da parte aérea, raízes e tubérculos.

O número de folhas foi determinado por contagem em laboratório. A área foliar $\left(\mathrm{cm}^{2}\right)$ das folhas retiradas, foi medida utilizando-se o analisador LI-3100 (LICOR, Lincoln, Nebraska). A massa seca foi obtida pela desidratação de todos os órgãos da planta (parte aérea, raízes, tubérculos) até peso constante, em estufa à temperatura de $60^{\circ} \mathrm{C}$, sob ventilação forçada.

Após a determinação dos parâmetros de crescimento, procedeu-se às análises de variância dos mesmos, de acordo com as recomendações de Buttery \& Buzzell (1972). 
Outros parâmetros de crescimento analisados foram a relação parte aérea/sistema radicular (RPAR), índice de área foliar (IAF), razão de área foliar (RAF), taxa de crescimento relativo (TCR), taxa de produção de matéria seca (TPMS) e índice de colheita (IC\%). Tais parâmetros foram obtidos utilizando-se as Equações 6 a 11.

A Equação 6 permite o estudo comparativo do desenvolvimento da parte aérea em relação ao desenvolvimento do sistema radicular.

RPAR $=\frac{P S A}{P S R}$

em que:

RPAR - Relação parte aérea/sistema radicular, adimensional;

PSA - Massa de matéria seca da parte aérea da planta, g; e

PSR - Massa de matéria seca do sistema radicular da planta, $\mathrm{g}$.

O índice calculado pela Equação 7 avalia a velocidade com que a área foliar ocupa a área do solo disponível à planta.

$\mathrm{IAF}=\frac{\mathrm{AF}}{\mathrm{S}}$

em que:

IAF - Índice de área foliar, adimensional;

AF - Área foliar, $\mathrm{dm}^{2} ; \mathrm{e}$

$\mathrm{S} \quad$ - Área do solo disponível à planta, $\mathrm{dm}^{2}$.

A RAF, calculada pela Equação 8, permite avaliar o desenvolvimento da área foliar em relação ao desenvolvimento da planta como um todo, em termos de matéria seca produzida em cada amostragem.

$\mathrm{RAF}=\frac{\mathrm{AF}}{\mathrm{PS}}$

em que:

RAF - Razão de área foliar, $\mathrm{dm}^{2} \mathrm{~g}^{-1} ; \mathrm{e}$ 
PS - Massa da matéria seca total, g.

A TCR, calculada pela Equação 9, avalia o crescimento da planta em termos de matéria seca formada por unidade de tempo, em função da massa inicial.

$\mathrm{TCR}=\frac{\mathrm{P} 2-\mathrm{P} 1}{\mathrm{t} 2-\mathrm{t} 1}$

em que:

TCR - Taxa de crescimento relativo, $\mathrm{g} \mathrm{g}^{-1} \mathrm{dia}^{-1}$;

P2 - Massa de matéria seca total da planta colhida na segunda amostragem, g;

P1 - Massa de matéria seca total da planta colhida na primeira amostragem, g; e

t2 et1 - Número dias da segunda e primeira amostragem, respectivamente.

A TPMS, também denominada fotossíntese líquida, calculada pela Equação 10, avalia o desenvolvimento da planta relacionando a quantidade de material orgânico acumulado, em função da área de solo ocupada pela planta, por unidade de tempo.

TPMS $=\frac{P 2-P 1}{S(t 2-t 1)}$

em que:

TPMS - Taxa de produção de matéria seca, $\mathrm{g} \mathrm{m}^{-2} \mathrm{dia}^{-1}$.

O IC, calculado pela Equação 11, avalia o desenvolvimento dos tubérculos em relação ao desenvolvimento total da planta, relacionando portanto fonte/dreno. 
$\mathrm{IC}=\frac{\mathrm{PE}}{\mathrm{PBT}} 100$

em que:

IC - Índice de colheita, \%;

PE - Produtividade econômica, $\mathrm{t} \mathrm{ha}^{-1} ; \mathrm{e}$

PBT - Produtividade biológica total, $\mathrm{t} \mathrm{ha}^{-1}$.

\subsubsection{Amostragem de parte aérea, raízes e tubérculos}

Pela ocasião da colheita (31/10/01), foi realizada a amostragem da parte aérea das plantas, coletando-se 10 plantas ao acaso (parte aérea total) das linhas centrais de cada tratamento e enviando-as para a análise. De igual forma foi realizada a amostragem das raízes.

Depois da colheita os tubérculos foram lavados e secos à sombra. Juntaram-se os tubérculos das quatro parcelas de cada tratamento, das quais foi realizada uma amostragem de 10 tubérculos ao acaso, para análise de macro e micronutrientes.

\subsubsection{Produtividade total de tubérculos}

Avaliourse a produtividade pela colheita de todos os tubérculos contidos nas linhas centrais de cada parcela (área útil), 10 dias após do corte da irrigação e eliminação total da parte aérea das plantas. Os tubérculos colhidos foram colocados em sacos identificados e conduzidos até o galpão, onde os mesmos foram escovados para a retirada do excesso de solo aderido, em seguida transportados para o laboratório. Seguiu-se a pesagem total dos tubérculos de cada parcela experimental. Pela proporção entre a massa total e a área útil da parcela experimental, obteve-se a produtividade total.

\subsubsection{Produtividade comercial de tubérculos}


Com a produtividade total de cada parcela experimental, realizourse a classificação dos tubérculos pelo diâmetro transversal, dividindo-os em quatro classes: especial ou "grauda" (com diâmetro maior que $45 \mathrm{~mm}$ ), primeira (com diâmetro entre 33 e $45 \mathrm{~mm}$ ), segunda (com diâmetro entre 23 e $33 \mathrm{~mm}$ ), e miudinha (tubérculos com diâmetro entre 20 e $23 \mathrm{~mm}$ ). Os tubérculos com diâmetro menor que $20 \mathrm{~mm}$ foram considerados como descarte, assim como aqueles que apresentavam ataque por Fusarium sp e Erwinia sp.

Pela proporção entre a massa total das classes especial, primeira, segunda e miudinha, e a área útil da parcela experimental, obteve-se a produtividade comercial.

\subsubsection{Teor de sólidos solúveis totais}

Foram escolhidos ao acaso 10 tubérculos de cada tratamento, os quais foram lavados, secos à sombra e levados ao laboratório para análise do teor de sólidos solúveis totais. Para isto, os tubérculos foram cortados transversalmente, obtendo-se gotas de suco celular da batata. Foram colocadas duas gotas sobre 0 prisma de um refratômetro digital, modelo PR-101 (0-45\%) realizando-se as leituras em $\stackrel{\circ}{ }$ Brix, e corrigidas para $20^{\circ} \mathrm{C}$.

\subsection{Experimento II}

\subsubsection{Características gerais}

Após analisados os resultados do Experimento I, e constatando-se a ausência de significância nas diferenças entre as dosagens de $\mathrm{CO}_{2}$ para 0 
cultivar Itararé, optourse por testar um menor número de dosagens, a fim de se verificar a resposta em outras variedades de batata.

O preparo do solo foi realizado um mês antes de ser instalado o experimento, efetuando-se duas arações seguidas de duas gradagens, para em parte poder homogeneizar o solo e reduzir o efeito da aplicação das diferentes dosagens de $\mathrm{CO}_{2}$ correspondentes ao primeiro experimento.

Terminada a preparação do solo, foi realizada uma amostragem composta a 20 e $40 \mathrm{~cm}$ de profundidade do solo, sendo as amostras enviadas ao laboratório para a análise de macro e micro nutrientes.

Seguindo a recomendação de adubação baseada nos resultados de análise de solo (Tabela 6a, 6b, e 7) e o requerimento nutricional das cultivares de batata, foram aplicados no plantio, no fundo do sulco, $2000 \mathrm{~kg} \mathrm{ha}^{-1}$ de Yoorin master $1 \mathrm{~s}\left(17 \% \mathrm{P}_{2} \mathrm{O}_{5} ; 6 \% \mathrm{~S} ; 0,1 \% \mathrm{~B} ; 0,55 \% \mathrm{Zn}\right), 150 \mathrm{~kg} \mathrm{ha}^{-1}$ de uréia, e $80 \mathrm{~kg}$ ha${ }^{1}$ de cloreto de potássio.

Tabela 6a. Análise química do solo do experimento II. Piracicaba, SP. 2002

\begin{tabular}{ccccc}
\hline Prof. & $\mathrm{pH}$ & $\mathrm{MO}$ & $\mathrm{P}$ & $\mathrm{S}$ \\
\cline { 4 - 5 }$(\mathrm{cm})$ & $\mathrm{CaCl}_{2}$ & $\left(\mathrm{~g} \mathrm{dm}^{-3}\right)$ & \multicolumn{3}{c}{$\left(\mathrm{mg} \mathrm{dm}^{-3}\right)$} \\
\hline $0-20$ & 5,28 & 31,8 & 22,8 & 94,4 \\
$20-40$ & 5,12 & 20,0 & 5,6 & 110,6 \\
\hline
\end{tabular}

Tabela 6b. Análise química do solo do experimento II. Piracicaba, SP. 2002

\begin{tabular}{cccccccccc}
\hline $\begin{array}{c}\text { Prof. } \\
(\mathrm{cm})\end{array}$ & $\mathrm{K}$ & $\mathrm{Ca}$ & $\mathrm{Mg}$ & $\mathrm{Al}$ & $\mathrm{H}+\mathrm{Al}$ & $\mathrm{SB}$ & $\mathrm{T}$ & \multirow{2}{*}{\begin{tabular}{c}
$\mathrm{V}$ \\
\cline { 4 - 7 }
\end{tabular}} \\
\hline $0-20$ & 4,3 & 56,4 & 16,6 & 0,0 & 35,8 & 77,3 & 113,1 & 67,8 \\
$20-40$ & 1,3 & 28,6 & 10,6 & 0,0 & 34,0 & 40,5 & 74,5 & 54,2 \\
\hline
\end{tabular}

Tabela 7. Análise de micronutrientes do solo do experimento II. Piracicaba, SP. 2002

\begin{tabular}{cccccc}
\hline $\begin{array}{c}\text { Profundidade } \\
(\mathrm{cm})\end{array}$ & $\mathrm{B}$ & $\mathrm{Cu}$ & $\mathrm{Fe}$ & $\mathrm{Mn}$ & $\mathrm{Zn}$ \\
\cline { 2 - 6 } & \multicolumn{5}{c}{$\mathrm{mg} \mathrm{dm}^{-3}$} \\
$20-20$ & 0,78 & 8,06 & 36,0 & 85,88 & 3,12 \\
$20-40$ & 0,23 & 4,26 & 20,8 & 27,16 & 0,88 \\
\hline
\end{tabular}


Aplicourse no sulco, anteriormente ao plantio, inseticida ALDICARB na dose de $30 \mathrm{~kg} \mathrm{ha}^{-1}$, junto ao fertilizante.

\subsubsection{Delineamento experimental}

O delineamento experimental utilizado foi o de blocos ao acaso com 9 tratamentos e arranjo em fatorial de $3 \times 3$, ou seja o primeiro fator 'cultivares de batata' com 3 níveis ('Atlantic', 'Jatte-Bintje', 'Monalisa') e o segundo fator 'doses de $\mathrm{CO}_{2}$ ' com 3 níveis $\left(0 ; 145,36\right.$; e 290,72 $\mathrm{kg} \mathrm{ha}^{-1}$, respectivamente) e 4 repetições.

A área foi dividida em 36 parcelas, com dimensões de 3,20 m de largura e 5,00 m de comprimento cada parcela, totalizando $576 \mathrm{~m}^{2}$ (Figura 8).

A análise da variância das variáveis de número de folhas, número de estolões, área foliar, número de tubérculos, massa seca da parte aérea, massa seca de raízes e, massa seca de tubérculos, das cultivares Atlantic, Jatte-Bintje e, Monalisa, foi realizada pelo análise de regressão múltipla utilizando o Software estatístico SPSS (Statistical Package for the Social Sciences).

O delineamento experimental para análise da variância das variáveis de pH no solo, produção total, classificação da produção, pH da polpa, acidez titulável, firmeza, teor de sólidos solúveis totais, coloração da polpa, teor de matéria seca, açúcares redutores e amido, foi o de blocos ao acaso com quatro repetições. 


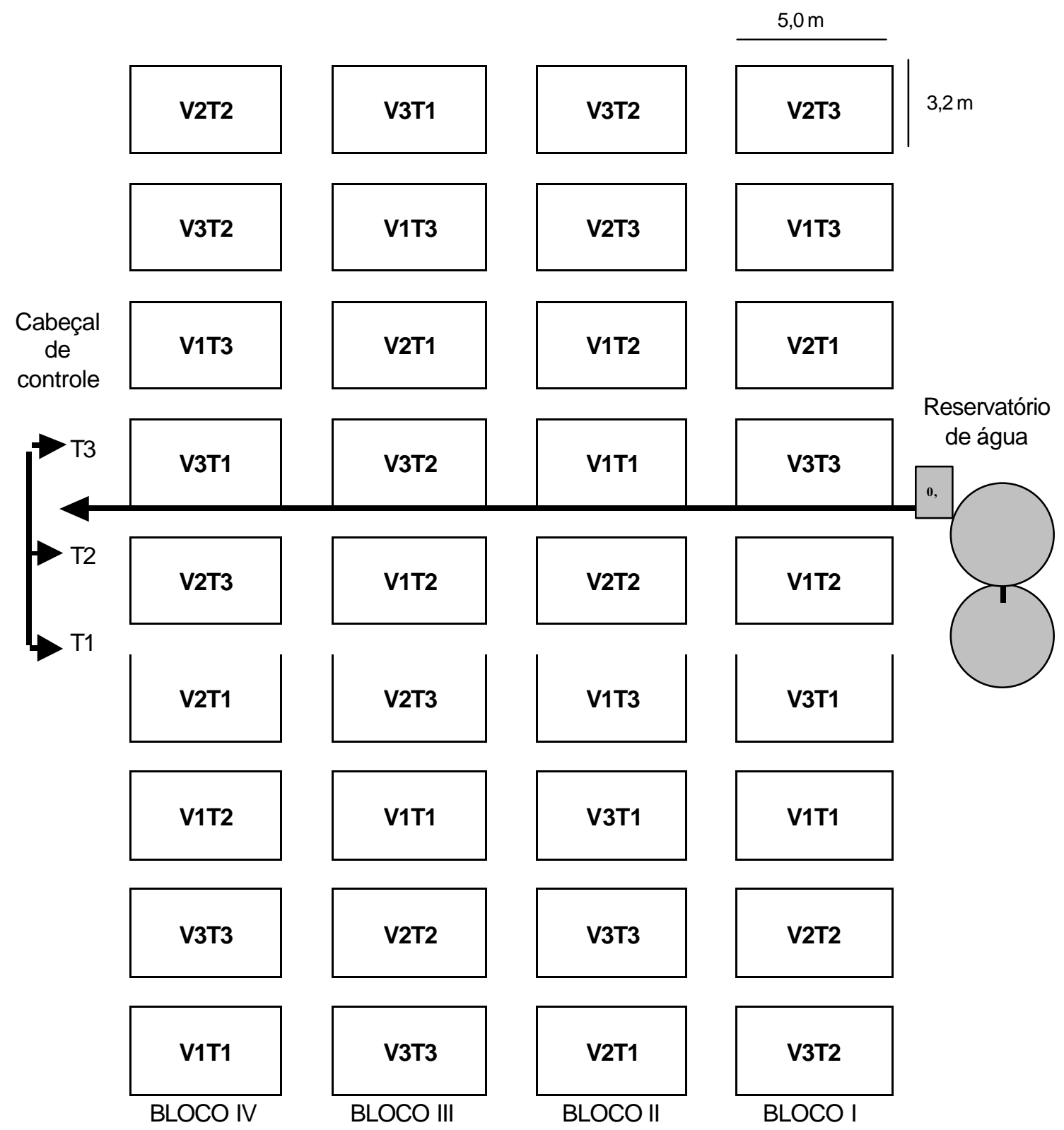

Figura 8 - Esquema do experimento II, mostrando a distribuição dos tratamentos (V1='Atlantic'; $\quad$ V2='Jatte-Bintje'; V3='Monalisa'; $\mathrm{T} 1=0 ; \mathrm{T} 2=145,36 ; \mathrm{T} 3=290,72 \mathrm{Kg} \mathrm{ha}^{-1}$ de $\mathrm{CO}_{2}$ 


\subsubsection{Sistema de irrigação}

A instalação do sistema de irrigação foi semelhante ao experimento I, variando somente no espaçamento entre os gotejadores de $0,1 \mathrm{~m}$ para 0,3 $\mathrm{m}$ nos tubogotejadores Queen Gil, mantendo-se as características diâmetro interno de $16,5 \mathrm{~mm}$, espessura da parede de $0,2 \mathrm{~mm}$, pressão recomendada de 50 a 70 kPa e vazão nominal de $4 \mathrm{~L} \mathrm{~m}^{-1} \mathrm{~h}^{-1}$.

\subsubsection{Plantio e condução da cultura}

O plantio foi realizado manualmente em 25 de maio de 2002 no espaçamento de 0,8 m entre linhas por 0,4 m entre tubérculos-semente e a uma profundidade de $0,15 \mathrm{~m}$. Posteriormente os mesmos foram cobertos com solo úmido. Nesta ocasião, foram utilizados os tubérculos-semente dos cultivares, Atlantic, Jatte-Bintje, e Monalisa, fornecidos pela Associação de Bataticultores Sudoeste Paulista (ABASP) com sede em Itapetininga, SP.

Aos 30 dias após plantio (DAP) por ocasião à primeira amontoa, aplicaram-se $140 \mathrm{~kg} \mathrm{ha}^{-1}$ de uréia, e $80 \mathrm{~kg} \mathrm{ha}^{-1}$ de cloreto de potássio.

O controle fitossanitário foi realizado de forma preventiva, segundo as variações climáticas (temperatura máxima do ar, temperatura mínima do ar e umidade relativa do ar) e as observações a campo, utilizando-se produtos recomendados para a cultura de batata.

O manejo de irrigação foi feito de forma semelhante àdo Experimento I.

\subsubsection{Aplicação e manejo de $\mathrm{CO}_{2}$}

Para este experimento foram utilizadas as doses de $\mathrm{CO}_{2}$ de $0,145,36$ e 290,72 Kg ha-1, respectivamente. Estas doses de dióxido de carbono foram 
baseadas na concentração média do $\mathrm{CO}_{2}$ na atmosfera que é de 367ppm ( $\mu \mathrm{mol}$ $\mathrm{CO}_{2} \mathrm{~mol}^{-1}$ ).

O sistema de aplicação de $\mathrm{CO}_{2}$ foi composto por dois cilindros de alta pressão com 15,1 L de capacidade, equipado com válvula reguladora de pressão, manômetro, fluxômetro para controlar a vazão do gás, e um injetor tipo venturi para introduzir o $\mathrm{CO}_{2}$ na água de irrigação.

Optourse pelo uso de fluxômetros ao invés de válvulas reguladoras de vazão, utilizadas no Experimento I, para um melhor controle do volume de gás aplicado. Este melhor controle é caracterizado pela presença de uma escala correspondente a vazão aplicada $\left(\mathrm{L} \mathrm{min}^{-1}\right)$. Tal escala e as correspondentes vazões são apresentadas na Tabela 8 . Além disso, foram realizadas as pesagens dos cilindros no inicio e final do experimento para o conhecimento da quantidade de $\mathrm{CO}_{2}$ aplicado, calculando-se, posteriormente, a dosagem utilizada, em $\mathrm{kg} \mathrm{ha}^{-1}$.

Tabela 8. Calibração da vazão de $\mathrm{CO}_{2}$ no fluxômetro

\begin{tabular}{cccccc}
\hline Trat. & $\begin{array}{c}\text { Dosagem de } \\
\mathrm{CO}_{2} \\
(\mathrm{ppm})\end{array}$ & $\begin{array}{c}\text { Volume a } \\
\text { aplicar } \\
\left(\mathrm{cm}^{3} \mathrm{CO}_{2} /\right. \\
\mathrm{L} \text { água })\end{array}$ & $\begin{array}{c}\text { Vazão } \\
\text { água/Trat. } \\
(12 \text { parcelas }) \\
\left(\mathrm{L} \mathrm{min}^{-1}\right)\end{array}$ & $\begin{array}{c}\text { Vazão } \\
\mathrm{CO}_{2} / \mathrm{Trat}^{-1} \\
\left(\mathrm{~L} \mathrm{~min}^{-1}\right)\end{array}$ & $\begin{array}{c}\text { Escala } \\
\text { de calibração } \\
\text { no fluxômetro }\end{array}$ \\
\hline T1 & 0 & 0,0 & 16,00 & 0,0 & 0,0 \\
T2 & 400 & 27,9 & 16,00 & 0,4464 & 5,68 \\
T3 & 800 & 55,8 & 16,00 & 0,8928 & 9,76 \\
\hline
\end{tabular}

O tempo de aplicação de $\mathrm{CO}_{2}$ variou em função da lâmina de irrigação, aplicando-o cinco minutos após iniciada a irrigação (momento em que o sistema estava pressurizado) e finalizando um minuto antes do término da irrigação.

\subsubsection{Medição do pH no solo}


Avaliourse o efeito do $\mathrm{CO}_{2}$ aplicado via água de irrigação no $\mathrm{pH}$ do solo. $\mathrm{O}$ pH do solo foi medido por um aparelho Soil Tester Modelo DM-5, Marca Demetra Tokyo, Japan, de leitura direta ao ser introduzido no solo úmido a $10 \mathrm{~cm}$ de profundidade.

As leituras foram realizadas, antes, durante e após aplicação de $\mathrm{CO}_{2}$, sendo que as três modalidades de leitura foram efetuadas em cada parcela apenas uma vez.

Antes do inicio da aplicação da água e $\mathrm{CO}_{2}$, três a quatro minutos após a estabilização do aparelho medidor, realizava-se a primeira leitura. A segunda leitura era realizada dez minutos após iniciada a irrigação e cinco minutos após iniciada a injeção de $\mathrm{CO}_{2}$ e a terceira leitura era realizada dez minutos após o termino da irrigação.

\subsubsection{Parâmetros avaliados}

Durante este experimento, efetuaram-se cinco avaliações do número de folhas, área foliar, número de estolões, número de tubérculos e da massa seca da parte aérea, das raízes e dos tubérculos, extraindo-se duas plantas laterais de cada parcela, no intervalo de quatorze dias, iniciando-se em vinte de junho 2002, ou seja, quatorze dias após emergência (DAE) e sete dias após início da aplicação de $\mathrm{CO}_{2}$. Essas avaliações foram efetuadas de forma similar a do Experimento I.

\subsubsection{Amostragem da parte aérea, raízes e tubérculos}

Por ocasião da colheita, em dezoito de setembro de 2002, efetuou-se uma amostragem da parte aérea total de dez plantas escolhidas ao acaso, das linhas 
centrais de cada tratamento, sendo as mesmas enviadas, juntamente com amostras de raízes, ao laboratório para análise.

Também foi realizada a amostragem dos tubérculos, para análise de macro e micronutrientes, lavando-os, secando-os à sombra e selecionando-os previamente. A seleção consistiu na separação de dez tubérculos ao acaso das quatro parcelas de cada tratamento.

\subsubsection{Produtividade total de tubérculos}

Realizou-se de forma similar ao experimento I. Pela proporção entre a massa total e a área útil da parcela experimental, obteve-se a produtividade total.

\subsubsection{Produtividade comercial de tubérculos}

Foi efetuada a classificação similar ao experimento l: dividindo-os em quatro classes: especial ou "graúda" (com diâmetro maior que $45 \mathrm{~mm}$ ), primeira (com diâmetro entre 33 e 45 mm), segunda (com diâmetro entre 23 e 33 mm), e "miudinha" (tubérculos com diâmetro entre 20 e 23 mm). Os tubérculos com diâmetro menor a $20 \mathrm{~mm}$ foram considerados como descarte, assim como aqueles que apresentavam más formações. Pela proporção entre a massa total das classes especial, primeira, segunda e miudinha e, a área útil da parcela experimental, obteve-se a produtividade comercial.

\subsubsection{Características tecnológicas dos tubérculos}

As características tecnológicas das batatas foram avaliadas em amostras de 4 tubérculos da classe especial, ou seja, com diâmetro superior a $45 \mathrm{~mm}$, 
tomados ao acaso, dentro de cada parcela experimental, lavados e secos à sombra.

\subsubsection{1 pH}

Os tubérculos foram fatiados em cortador inox e uma amostra de $50 \mathrm{~g}$ desse material foi triturada em homogeneizador com $100 \mathrm{~mL}$ de água destilada. A leitura do $\mathrm{pH}$ deste extrato foi realizada em potenciômetro TECNOPON, modelo MPA210.

\subsubsection{Acidez titulável}

Um extrato preparado do mesmo modo que no item 3.4.11.1 foi titulado com solução de hidróxido de sódio $0,1 \mathrm{~N}$ até $\mathrm{pH} 8,1$, utilizando-se potenciômetro digital (TECNOPON, modelo MPA210). Para cálculo da acidez utilizou-se a fórmula apresentada na Equação 12. Os resultados foram expressos em percentual do ácido presente em maior quantidade na amostra em estudo, que é o ácido cítrico.

$$
A C=\frac{(V 0,64)}{P}
$$

sendo:

AC - Acidez titulável, \% de ácido cítrico;

$\mathrm{V} \quad$ - Volume de $\mathrm{NaOH} 0,1 \mathrm{~N}$ gasto na titulação, $\mathrm{mL}$;

P - Quantidade da amostra, g. 


\subsubsection{Firmeza}

A firmeza das batatas foi avaliada utilizando-se um penetrômetro manual, modelo FT-327 (3 a 27 lbs) e ponteira de 8 mm de diâmetro. Foram efetuadas duas leituras em cada tubérculo, em lados opostos da região equatorial, e os resultados expressos em Newton metro ${ }^{-2}\left(\mathrm{~N} \mathrm{~m}^{-2}\right)$.

\subsubsection{Sólidos solúveis totais}

Para esta avaliação os tubérculos foram cortados em pedaços e prensados. Duas gotas do suco resultante da prensagem foram colocadas no prisma do refratômetro eletrônico ATAGO, modelo DBX-30 e efetuada a leitura dos graus Brix a $20^{\circ} \mathrm{C}$. Os resultados foram expressos em percentual a base de peso.

\subsubsection{Coloração da polpa}

Para esta determinação cada tubérculo era dividido em duas metades e as leituras de cor efetuadas em ambas as superfícies, na região central da polpa. A coloração da polpa dos tubérculos foi avaliada em colorímetro, modelo MINOLTA CHROMA METER, modelo CR-200B, e expressa no sistema L* (luminosidade com escala de 0 a 100), $a^{*}$ (escala de -60 , correspondente à cor verde $a+60$, que corresponde a cor vermelha) e b* (escala de -60, correspondente à cor azul $a+60$, que corresponde à cor amarela).

\subsubsection{Teor de matéria seca}


O teor de matéria seca foi determinado em amostras de tubérculos fatiados em cortador inox. Cerca de $7 \mathrm{~g}$ destas fatias foram colocadas em placas de Petri e submetidas à secagem em estufa com circulação forçada de ar, a $105^{\circ} \mathrm{C}$, até peso constante. $\mathrm{O}$ teor de matéria seca dos tubérculos foi obtido pela Equação 13.

$M S=\frac{P f}{P i} \quad 100$

sendo:

$$
\begin{array}{ll}
\text { MS } & \text { - Teor de matéria seca, \%; } \\
\mathrm{Pf} & - \text { Peso final da amostra, \%; } \\
\mathrm{Pi} & - \text { Peso inicial da amostra, g. }
\end{array}
$$

\subsubsection{Teor de açúcares redutores}

Os tubérculos foram fatiados em cortador inox, desidratados em estufa com circulação forçada de ar a 45ํㅡ por 24 horas e moído em moínho tipo Willey. A metodologia utilizada para a determinação dos açúcares redutores foi a de Somogy-Nelson (Somogy, 1945).

\subsubsection{Teor de amido}

Os tubérculos foram fatiados em cortador inox, desidratados em estufa com circulação forçada de ar a $45^{\circ} \mathrm{C}$ por 24 horas e moído em moínho tipo Willey. O teor de amido foi determinado pela metodologia enzimática de Rickard \& Behn (1987) e a dosagem de açúcares redutores por Somogy-Nelson (Somogy, 1945). 


\section{RESULTADOS E DISCUSSÃO}

\subsection{Estudo preliminar}

\subsubsection{Ponto de saturação de luz e ponto de compensação de $\mathrm{CO}_{2}$}

As medições foram realizadas tanto pela manhã como durante a tarde. Na Figura 9, observa-se que os dois horários não tiveram diferença, conforme mostra o desvio padrão. Nesta curva pode-se observar que o maior valor de fotossíntese foi obtido quando o valor de DFFFA (Densidade de Fluxo de Fótons Fotossintéticamente Ativos) era em torno de $1.000 \mu \mathrm{mol}$ fotons $\mathrm{m}^{-2} \mathrm{~s}^{-1}$.

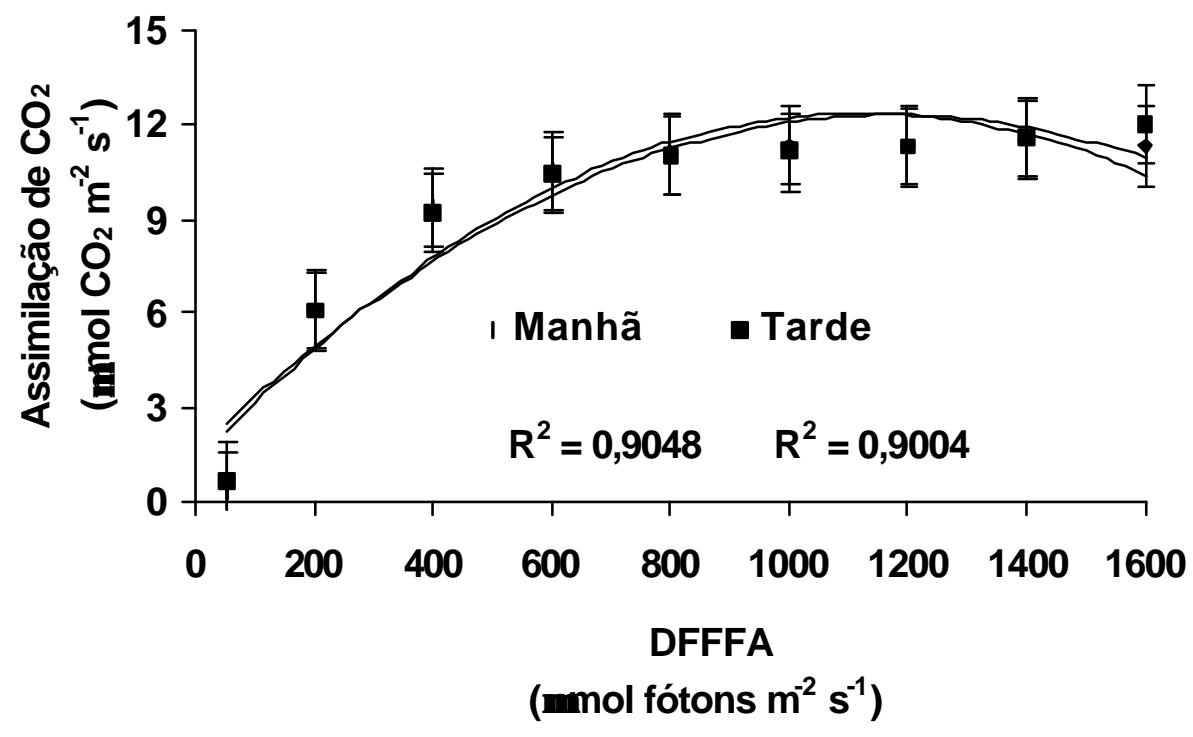

Figura 9 - Taxa de assimilação de $\mathrm{CO}_{2}(\mathrm{~A})$ em função da densidade de fluxo de fótons fotossinteticamente ativos (DFFFA), sob concentração de $\mathrm{CO}_{2}$ para batata cv. Itararé, medidos em casa de vegetação 
A equação representativa da curva foi o modelo polinomial de segundo grau conforme visto na Equação 14.

$$
A=1,2718+0,0197 D F F F A-9 \cdot 10^{-6} \cdot \text { DFFFA }^{2}
$$

em que:

A - Assimilação de $\mathrm{CO}_{2}, \mu \mathrm{mol} \mathrm{CO}_{2} \mathrm{~m}^{-2} \mathrm{~s}^{-1}$;

DFFFA - Densidade de fluxo de fótons fotossinteticamente ativos, $\mu$ mol fótons $\mathrm{m}^{-2} \mathrm{~s}^{-1}$; e.

$\mathrm{R}^{2}$

- 0,9048

A partir da equação ajustada para a assimilação de $\mathrm{CO}_{2}$ em função de DFFFA, estimourse o ponto de compensação luminosa, obtendo-se um valor $A$ máximo de $12,05 \mu \mathrm{mol} \mathrm{CO}_{2} \mathrm{~m}^{-2} \mathrm{~s}^{-1}$, quando o valor de DFFFA era de $1.094,44$ $\mu \mathrm{mol}$ fótons $\mathrm{m}^{-2} \mathrm{~s}^{-1}$.

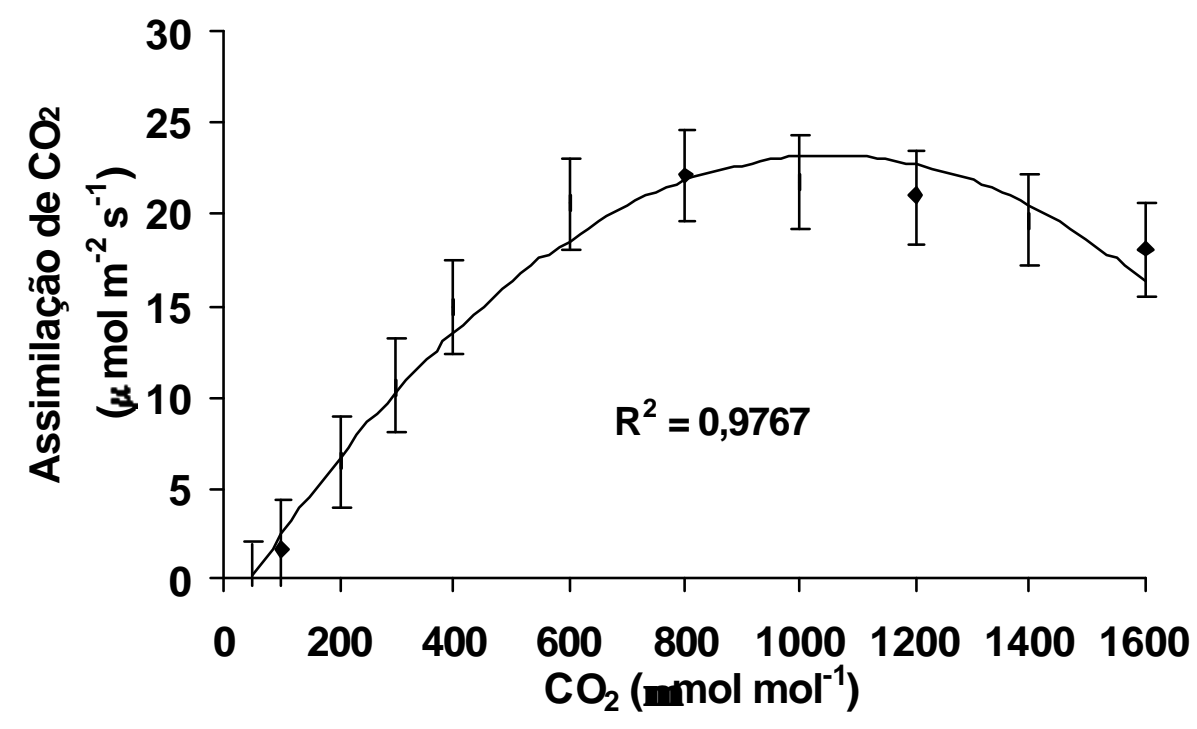

Figura 10 - Taxa de assimilação de $\mathrm{CO}_{2}$ em função da concentração de $\mathrm{CO}_{2}$, para a densidade de fluxo de fótons fotossinteticamente ativos (DFFFA) de $1.000 \mu \mathrm{mol}$ fótons $\mathrm{m}^{-2} \mathrm{~s}^{-1}$ para a cultura de batata 'Itararé' cultivadas em casa de vegetação 
Na Figura 10, sob DFFFA de $1.000 \mu$ mol fótons $\mathrm{m}^{-2} \mathrm{~s}^{-1}$ pode-se observar o incremento na assimilação de $\mathrm{CO}_{2}$ a medida que aumenta a concentração de $\mathrm{CO}_{2}$, até chegar a um máximo de assimilação de $\mathrm{CO}_{2}$, para então começar a cair.

A partir da equação ajustada (Equação 15) para assimilação de $\mathrm{CO}_{2} \mathrm{em}$ função da concentração de $\mathrm{CO}_{2}$ obteve-se um valor máximo de $\mathrm{A}(27,13 \mu \mathrm{mol}$ $\mathrm{CO}_{2} \mathrm{~m}^{-2} \mathrm{~s}^{-1}$ ) com a concentração de $\mathrm{CO}_{2}$ igual a $1.210 \mu \mathrm{mol} \mathrm{mol}$.

$$
\mathrm{A}=-2,1502+0,0484 \cdot\left[\mathrm{CO}_{2}\right]-2 \cdot 10^{-5} \cdot\left[\mathrm{CO}_{2}\right]^{2}
$$

em que:

$$
\begin{array}{ll}
\mathrm{A} & - \text { Assimilação de } \mathrm{CO}_{2}, \mu \mathrm{mol} \mathrm{CO}_{2} \mathrm{~m}^{-2} \mathrm{~s}^{-1} ; \\
\mathrm{CO}_{2} & - \text { Concentração de dióxido de carbono, } \mu \mathrm{mol} \mathrm{mol}{ }^{-1} ; \mathrm{e} \\
\mathrm{R}^{2} & -0,9767
\end{array}
$$

Os níveis de assimilação máxima de $\mathrm{CO}_{2}$ variam nas diferentes espécies, mesmo dentro do grupo de plantas C3. Gomes (2001), encontrou uma assimilação máxima de $\mathrm{CO}_{2}$ quando o valor de DFFFA foi de $1400 \mu$ mol fótons $\mathrm{m}^{-2} \mathrm{~s}^{-1}$ e a concentração de $\mathrm{CO}_{2}$ foi de $600 \mu \mathrm{mol} \mathrm{CO}_{2} \mathrm{~mol}^{-1}$ para a cultura de alface.

\subsection{Experimento I}

\subsubsection{Elementos meteorológicos}

Foram coletadas da base de dados da ESALQ (2001), as umidades relativas, assim como a média dos valores de temperatura mínima, temperatura máxima e temperatura média, os quais são apresentados na Tabela 9. 
Tabela 9. Elementos meteorológicos observados durante o experimento I. Piracicaba, SP. 2001

\begin{tabular}{lcccc}
\hline \multirow{2}{*}{ Meses } & \multirow{2}{*}{ UR $(\%)$} & \multicolumn{2}{c}{ TEMP. MÉDIA MENSAL DO AR } & \multirow{2}{*}{$\left({ }^{\circ} \mathrm{C}\right)$} \\
\cline { 2 - 4 } & & Máx. $\left({ }^{\circ} \mathrm{C}\right)$ & Mín. $\left({ }^{\circ} \mathrm{C}\right)$ & \\
\cline { 3 - 4 } & 72 & 26,3 & 10,9 & 18,6 \\
Julho & 65 & 28,0 & 12,4 & 20,2 \\
Agosto & 67 & 28,1 & 14,7 & 21,4 \\
Setembro & 69 & 29,5 & 16,1 & 22,8 \\
Outubro & & &
\end{tabular}

Na Figura 11 estão apresentados os dados referentes às condições climáticas durante o ciclo da cultura.

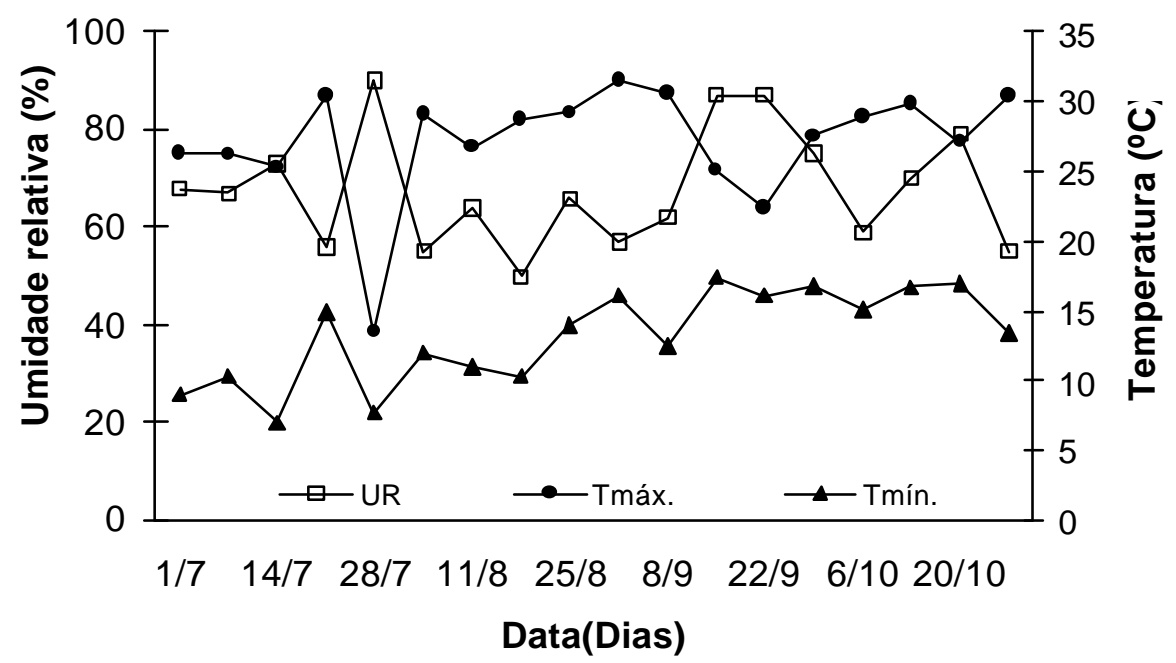

Figura 11 - Valores semanais de umidade relativa, temperatura máxima, mínima do ar durante o período correspondente ao experimento I. Piracicaba, S.P. 2001

\subsubsection{Uniformidade de irrigação}

O comportamento da uniformidade de irrigação, apresentado na Figura 12, mostra a uniformidade estatística de 92,1\% e coeficiente de variação de $7,9 \%$. Estes valores estão dentro da faixa indicada por Bernardo (1995) para o sistema de irrigação localizada e indicam uma boa distribuição de água nas parcelas. 


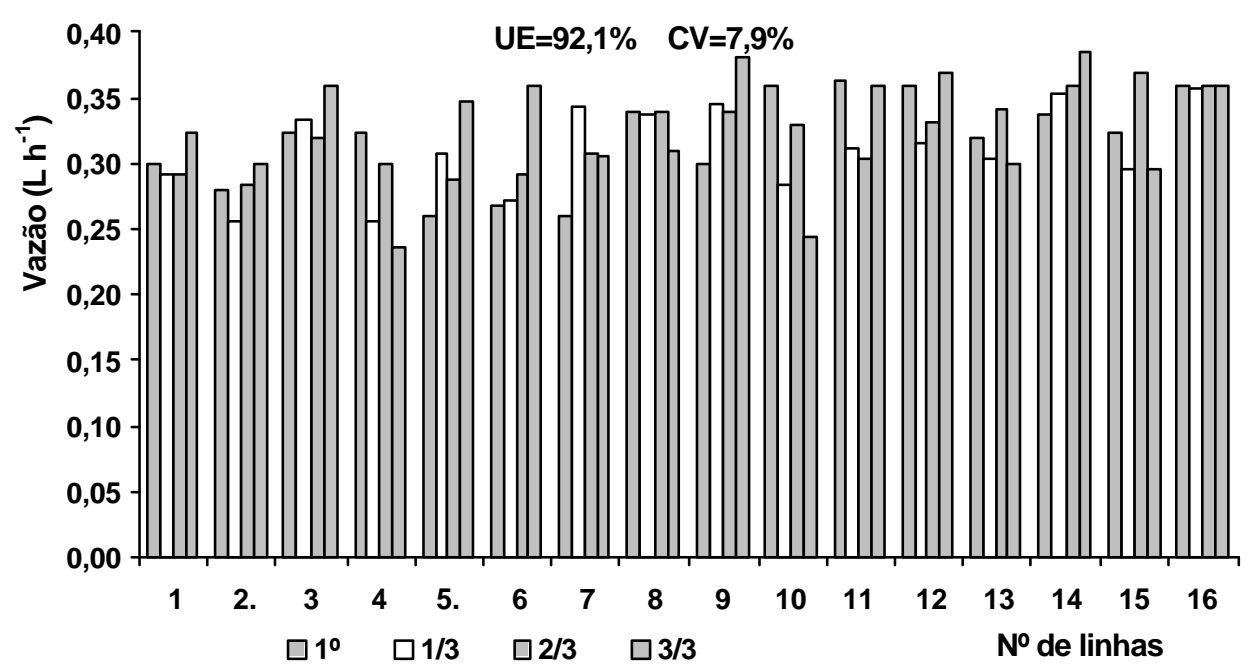

Figura 12 - Uniformidade de distribuição de irrigação do experimento I

\subsubsection{Manejo de irrigação e aplicação de $\mathrm{CO}_{2}$}

\subsubsection{Irrigação}

A lâmina de água aplicada à cultura, pela irrigação, durante o ciclo de 115 dias, foi de 123,69 mm. Nesse mesmo período registrou-se precipitação total de $263,67 \mathrm{~mm}$, resultando num total de lâmina de água adicionada ao solo de 387,36 $\mathrm{mm}$. O total de evaporação pelo tanque Classe A durante o período foi de 361,14 $\mathrm{mm}$.

A umidade do solo foi acompanhada pela leitura do potencial mátrico, estabelecendo-se como critério a manutenção da umidade do solo próximo à capacidade de campo. Na Figura 13 observa-se o potencial mátrico, o qual em módulo foi ligeiramente inferior a $10 \mathrm{kPa}$ na maior parte do período de cultivo, indicando um possível excesso de água. 


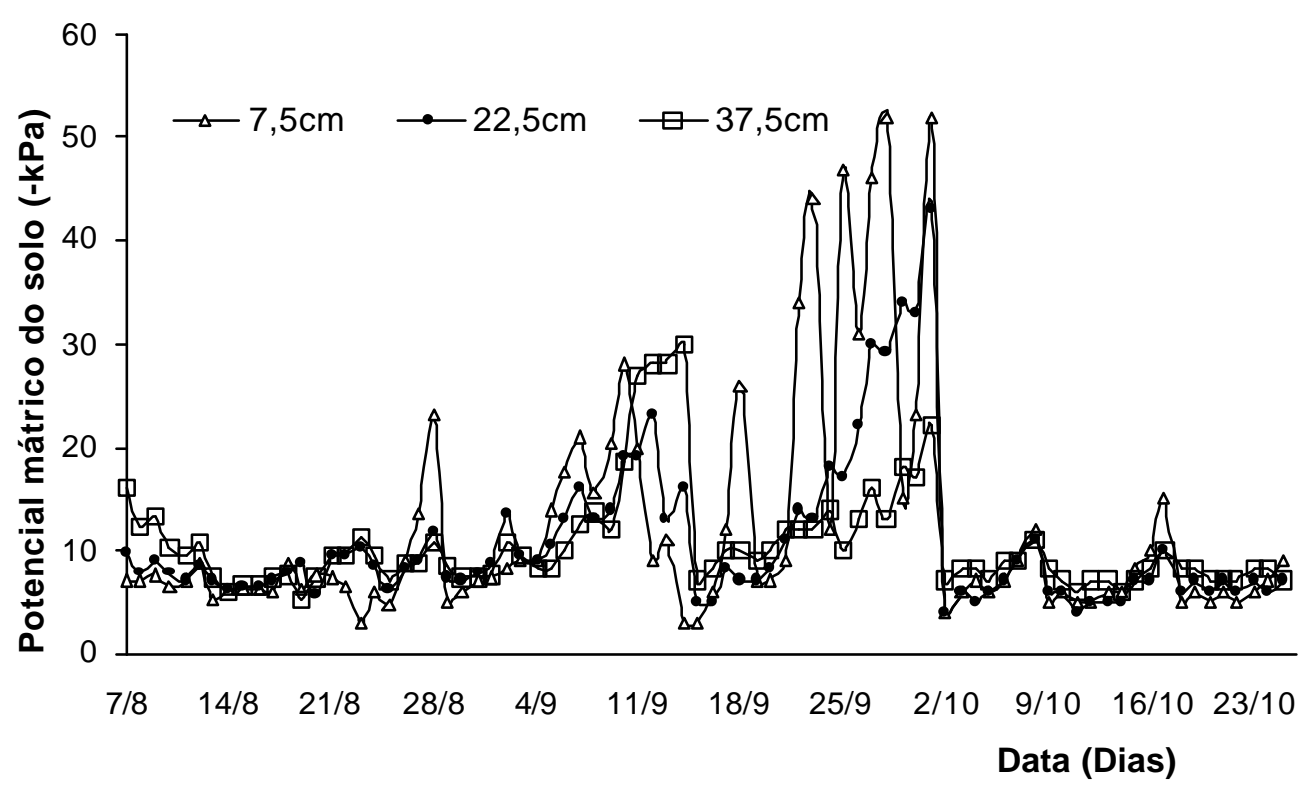

Figura 13 - Leitura dos tensiômetros (-kPa) a três profundidades nas parcelas durante o período do experimento I

No período que durou o experimento registraram-se chuvas concentradas, ocorrendo com mais freqüência na última fase da cultura, diminuindo o potencial mátrico do solo em módulo a níveis menores que $10 \mathrm{kPa}$. Isto ocasionou a interrupção da aplicação de água e consequentemente do $\mathrm{CO}_{2}$.

Na Figura 14 observa-se que a aplicação da irrigação começou muito cedo, ou seja, o solo ainda tinha umidade suficiente para permitir o brotamento. Como resultado obteve-se falha no "stand" de brotamento devido a podridão de alguns tubérculos-semente. 


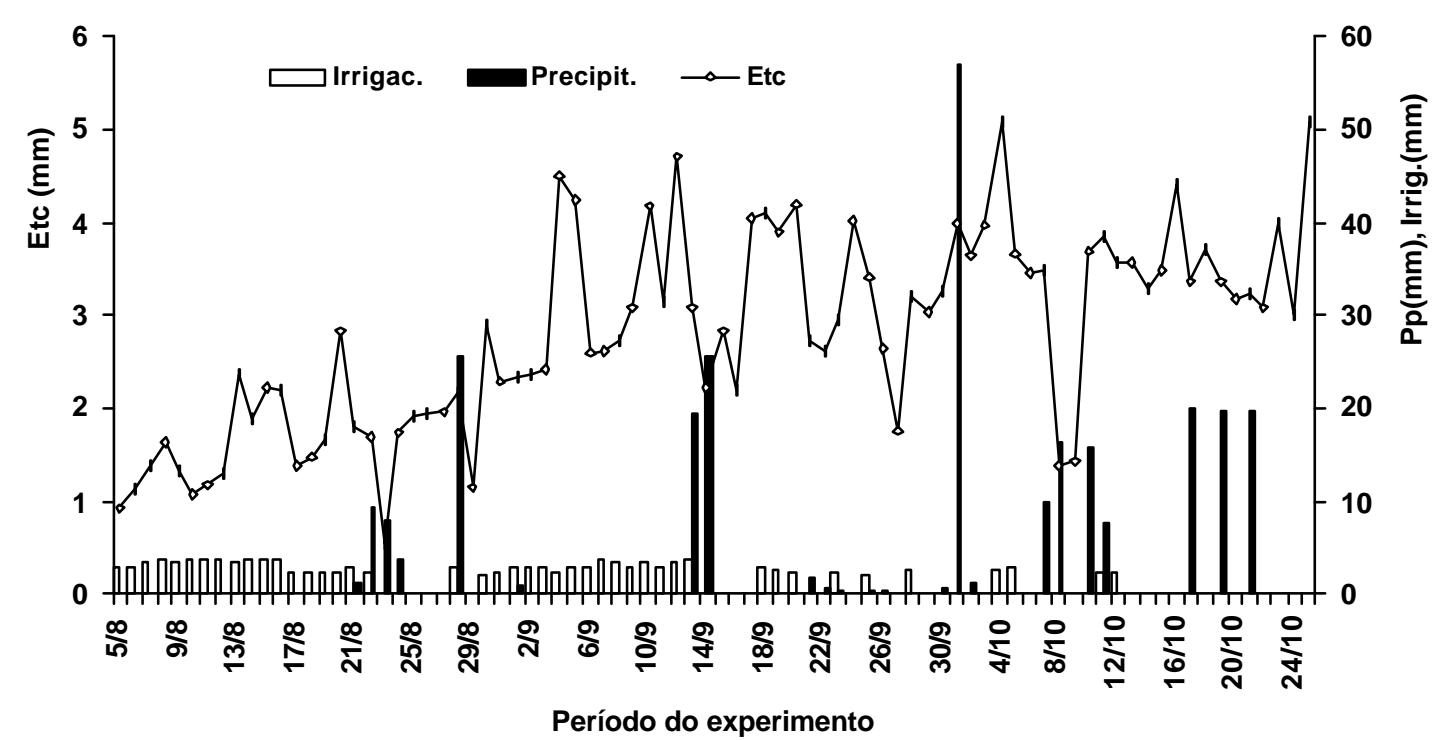

Figura 14 - Quantidade de água aplicada, evapotranspiração da cultura (ETc) e precipitação durante o experimento I

\subsubsection{Aplicação de $\mathrm{CO}_{2}$}

$\mathrm{Na}$ Tabela 10 apresenta-se a quantidade de $\mathrm{CO}_{2}$ por hectare utilizada tanto teórica como real, em cada tratamento durante o período do experimento I. O valor real foi obtido pela diferença de pesagem dos cilindros com $\mathrm{CO}_{2}$, realizada no início e no final do experimento.

Tabela 10. Quantidade de $\mathrm{CO}_{2}$ por hectare utilizada na cultura de batata $\mathrm{cv}$. Itararé durante o ciclo da cultura no experimento I, 2001

\begin{tabular}{cccc}
\hline Tratamento & $\begin{array}{c}\text { Dosagem de } \mathrm{CO}_{2} \\
\text { (ppm) }\end{array}$ & \multicolumn{2}{c}{$\mathrm{CO}_{2}$ utilizado $\left(\mathrm{kg} \mathrm{ha}^{-1}\right)$} \\
\cline { 3 - 4 } & 370 (atmosférico) & 0,0 & Real \\
\hline $\mathrm{T} 1$ & 580 & 205,20 & 0,0 \\
$\mathrm{~T} 2$ & 790 & 279,36 & 148,12 \\
$\mathrm{~T} 3$ & 1000 & 353,52 & 219,22 \\
$\mathrm{~T} 4$ & 1210 & 427,68 & 358,91 \\
$\mathrm{~T} 5$ & & & 923,75 \\
\hline
\end{tabular}

Pode-se observar na Tabela 10, uma diferença na quantidade teórica e real de $\mathrm{CO}_{2}$ utilizado, possivelmente devido à calibração. Já no tratamento T5 
correspondente a $1.210 \mathrm{ppm}$ obteve-se um valor muito elevado de $\mathrm{CO}_{2}$ real como conseqüência de fuga de gás pelo conector que causou aplicação de dosagem excessiva.

\subsubsection{Acúmulo de nutrientes na parte aérea, raízes e tubérculos}

Para determinar a quantidade total de nutrientes acumulados em cada uma das partes da planta, e como os resultados das análises apresentaram as concentrações dos macronutrientes em g kg${ }^{-1}$ e dos micronutrientes em mg kg-1, multiplicou-se a concentração de cada nutriente pela massa de material seco de cada órgão da planta.

O acúmulo total máximo corresponde à necessidade total do nutriente para a cultura, e varia em função da produtividade e da cultivar.

$\mathrm{Na}$ Figura 15 apresenta-se o xúmulo dos macronutrientes: nitrogênio, fósforo, potássio, cálcio, magnésio e enxofre na parte aérea, raízes e tubérculos de batata cv. Itararé.

Observa-se que o acúmulo máximo de nitrogênio total foi de 3.355,68 mg planta $^{-1}\left(104,88 \mathrm{~kg} \mathrm{ha}^{-1}\right.$ ) aos 103 DAP para dose 1 (sem aplicação de $\mathrm{CO}_{2}$ ) para uma produtividade de $19,7 \mathrm{t} \mathrm{ha}^{-1}$; e a máxima de $4.192,64 \mathrm{mg} \mathrm{ha}^{-1}\left(131,02 \mathrm{~kg}^{-} \mathrm{a}^{-}\right.$ $\left.{ }^{1}\right)$ para a dose 2 de $\mathrm{CO}_{2}\left(205,2 \mathrm{~kg} \mathrm{ha}^{-1}\right)$ para uma produtividade de 22,03 $\mathrm{t} \mathrm{ha}{ }^{-1}$. Jackson \& Haddock (1959) encontraram um acúmulo de $155 \mathrm{~kg} \mathrm{ha}^{-1} \mathrm{de} \mathrm{N}$ no cv. Russet Burbank para 38 t ha $^{-1}$.

Observa-se também que tanto a parte aérea como os tubérculos acumularam 47,17 e 51,55\% de $\mathrm{N}$ respectivamente, e o acúmulo nas raízes alcança pouco mais de 1\%. Paula et al.. (1986a) observaram que a maior parte de nitrogênio acumulado estava nos tubérculos (88\%) do cv. Achat e $80 \%$ no cv. Mantiqueira.

O acúmulo máximo de fósforo total para a dose 1 foi de $335,37 \mathrm{mg}$ planta

${ }^{1}$ (9,54 $\left.\mathrm{kg} \mathrm{ha}^{-1}\right)$ para uma produtividade de $19,7 \mathrm{t} \mathrm{ha}^{-1}$, encontrando-se acumulado 
$62 \%$ nos tubérculos e $36 \%$ na parte aérea, sendo o acúmulo
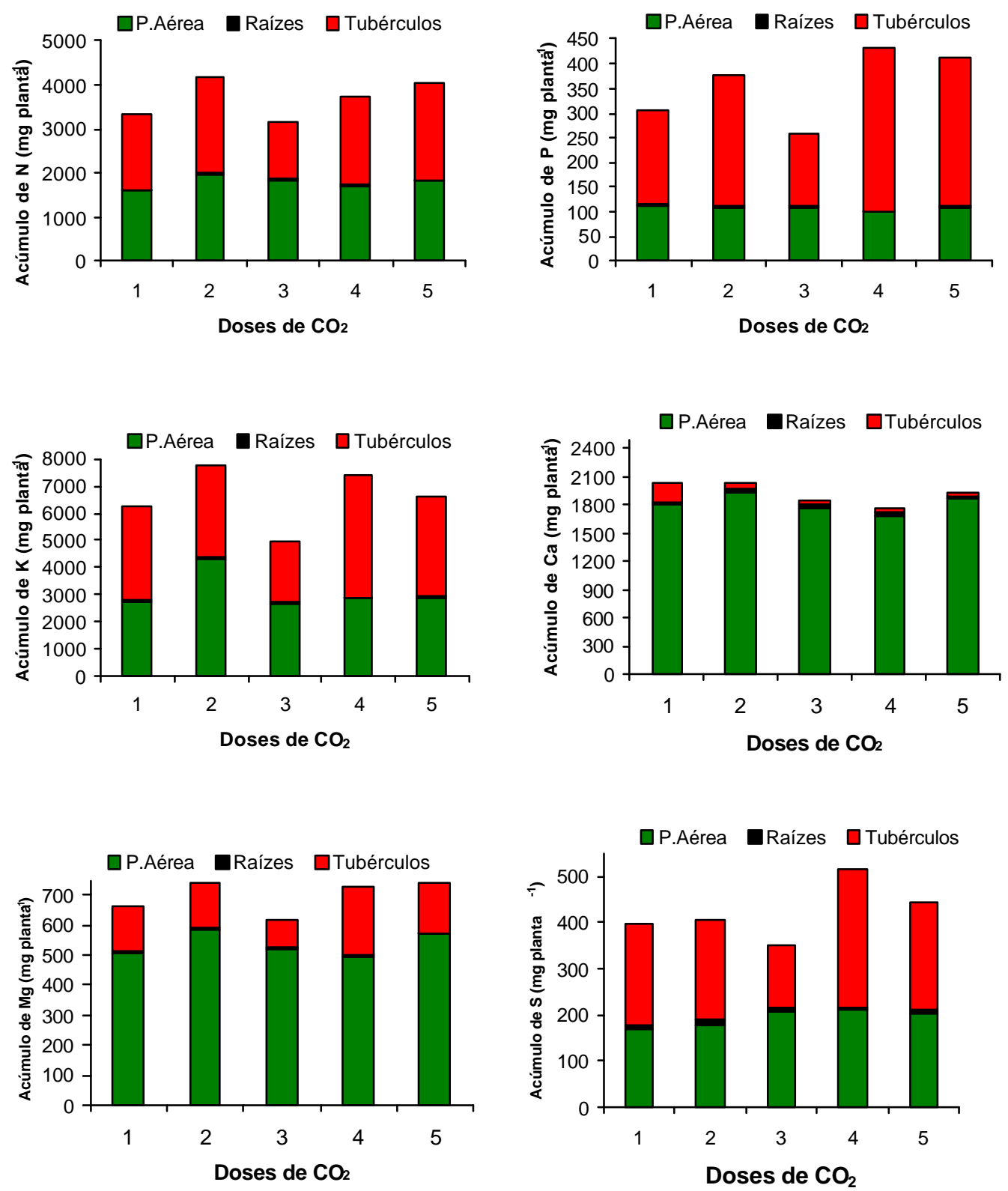

Figura 15 - Nitrogênio, Fósforo, Potássio, Cálcio, Magnésio, e Enxofre acumulado nos órgãos da batata aos 103 DAP (mg planta $\left.{ }^{-1}\right)$ em função das doses 1=0; 2=205,5; $3=279,36 ; 4=353,52 ;$ e 5=427,68 $\mathrm{kg} \mathrm{ha}^{-1}$ de $\mathrm{CO}_{2}$ 
máximo de fósforo total de $434 \mathrm{mg}$ planta $^{-1}\left(13,58 \mathrm{~kg} \mathrm{ha}^{-1}\right)$ quando aplicado a doses 4 de $\mathrm{CO}_{2}\left(353,52 \mathrm{~kg} \mathrm{ha}^{-1}\right)$ para uma produtividade de 19,89 $\mathrm{t} \mathrm{ha}^{-1}$, acumulado $76,7 \%$ nos tubérculos e $23 \%$ na parte aérea. Jackson \& Haddock (1959) observaram, um acúmulo máximo de fósforo de $13 \mathrm{~kg} \mathrm{ha}^{-1}$ para $38 \mathrm{t} \mathrm{ha}^{-1}$ no cv. Rosset Burbank.

O acúmulo máximo de potássio total para a dose 1 foi de $6.261,13 \mathrm{mg}$ planta $^{-1}$ (195,66 kg ha $\mathrm{kg}^{-1}$ para uma produtividade de 19,7 $\mathrm{t} \mathrm{ha}^{-1}$, fracionado em $55 \%$ nos tubérculos e $43,5 \%$ na parte aérea, sendo o máximo acúmulo de potássio total encontrado de 7.739,35 $\mathrm{mg}$ planta $^{-1}\left(241,85 \mathrm{~kg} \mathrm{ha}^{-1}\right)$ quando aplicado a dose 2 de $\mathrm{CO}_{2}\left(205,2 \mathrm{~kg} \mathrm{ha}^{-1}\right)$ para uma produtividade de 22,03 $\mathrm{t} \mathrm{ha}^{-1}$, encontrando-se acumulado $43 \%$ nos tubérculos e $55 \%$ na parte aérea. Hawkins (1946), observou um acúmulo máximo de potássio total de $215 \mathrm{~kg} \mathrm{ha}^{-1}$ no cv. Green Mountain para uma produtividade de $29 \mathrm{t} \mathrm{ha}^{-1}$.

O acúmulo máximo de cálcio total para a dose 1 foi de 2036,30 mg planta $^{-1}\left(63,63 \mathrm{~kg} \mathrm{ha}^{-1}\right)$ para uma produtividade de 19,7 $\mathrm{t} \mathrm{ha}^{-1}$, encontrando-se acumulado $88 \%$ na parte aérea e $10 \%$ nos tubérculos, sendo o máximo acúmulo de cálcio total também com a dose 1. Ezeta \& McCollum (1972), no cv. Renacimiento, observaram acúmulo máximo de $60 \mathrm{~kg} \mathrm{ha}^{-1}$.

O acúmulo máximo de magnésio total para a dose 1 foi de $665,93 \mathrm{mg}$ planta $^{-1}\left(20,81 \mathrm{~kg} \mathrm{ha}^{-1}\right)$ para uma produtividade de 19,7 tha ${ }^{-1}$, fracionado em $76,6 \%$ na parte aérea e $22,5 \%$ nos tubérculos, sendo o máximo acúmulo de magnésio total de $741,73 \mathrm{mg}$ planta ${ }^{-1}\left(23,18 \mathrm{~kg} \mathrm{ha}^{-1}\right)$ para uma produtividade de $20,70 \mathrm{t} \mathrm{ha}^{-1}$ quando aplicado a dose 5 de $\mathrm{CO}_{2}\left(427,68 \mathrm{~kg} \mathrm{ha}^{-1}\right)$, encontrando-se acumulado $22,6 \%$ nos tubérculos e $76,7 \%$ na parte aérea. Paula et al. (1986a) encontraram acúmulo máximo de 4,8 e 2,4 $\mathrm{kg} \mathrm{ha}^{-1}$ de magnésio nos cultivares Mantiqueira e Achat, respectivamente.

O acúmulo máximo de enxofre total para a dose 1 foi de $394,80 \mathrm{mg}$ planta $^{-1}\left(12,34 \mathrm{~kg} \mathrm{ha}^{-1}\right)$ para uma produtividade de 19,7 tha ${ }^{-1}$, fracionado em 55\% nos tubérculos e $43,07 \%$ na parte aérea, sendo o máximo acúmulo de enxofre 
total foi $516,26 \mathrm{mg}$ planta $^{-1}\left(16,13 \mathrm{~kg} \mathrm{ha}^{-1}\right)$ para uma produtividade de $19,89 \mathrm{t} \mathrm{ha}^{-1}$ quando aplicado a dose 4 de $\mathrm{CO}_{2}\left(353,52 \mathrm{~kg} \mathrm{ha}^{-1}\right)$, encontrando-se acumulado $40,5 \%$ na parte aérea e 58,16\% nos tubérculos. Hawkins (1946), encontrou acúmulo máximo de $12 \mathrm{~kg} \mathrm{ha}^{-1}$ no cv Green Mountain.

Na Figura 16 apresenta-se o acúmulo dos micronutrientes na parte aérea, raízes e tubérculos da batata cv. Itararé.
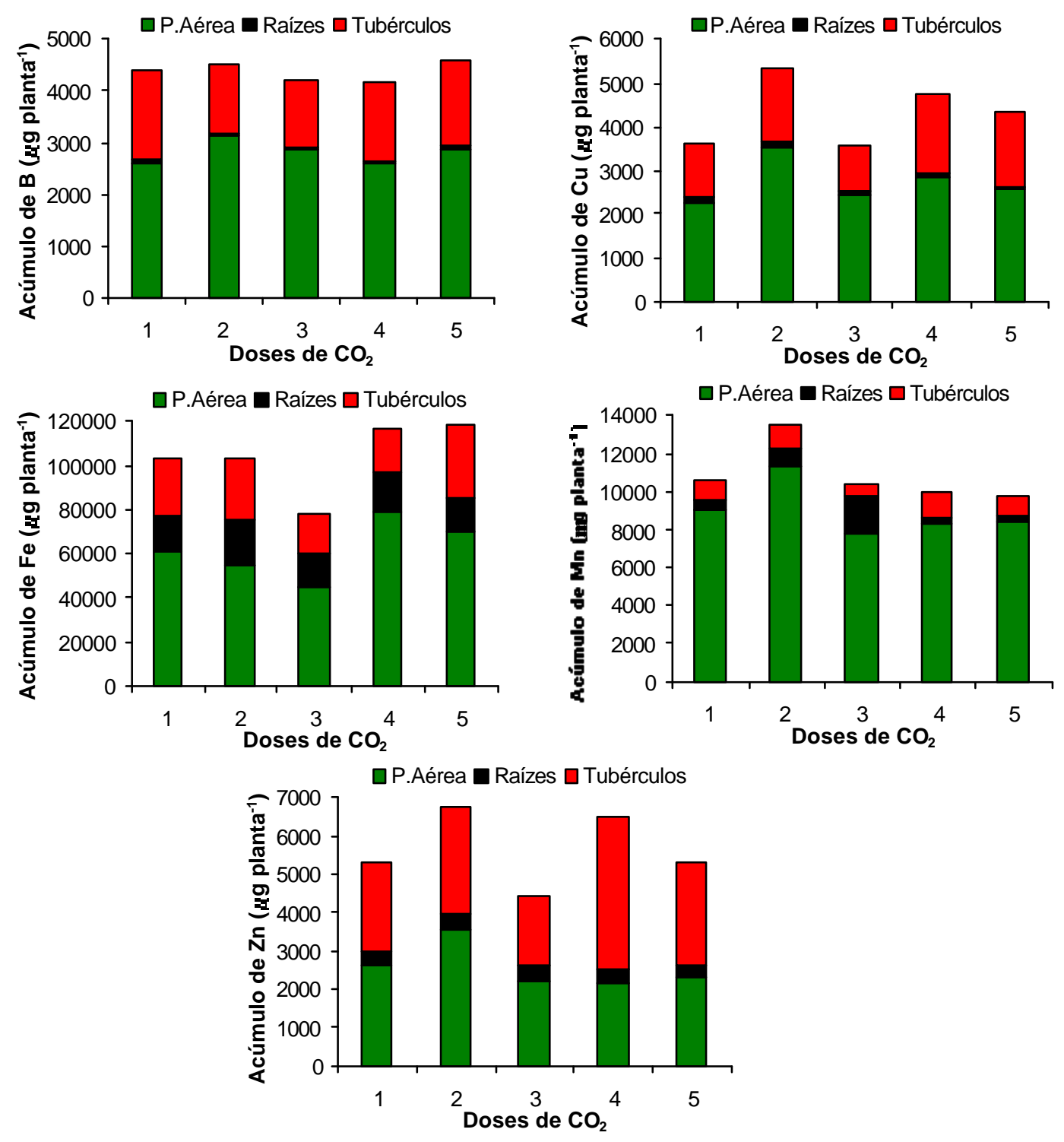
Figura 16 - Boro, Cobre, Ferro, Manganês, e zinco acumulado nos órgãos da batata aos 103 DAP ( $\mu$ g planta $\left.{ }^{-1}\right)$ em função das doses $1=0$; $2=205,5 ; 3=279,36 ; 4=353,52$; e $5=427,68 \mathrm{~kg} \mathrm{ha}^{-1}$ de $\mathrm{CO}_{2}$

O acúmulo máximo de boro total aos 103 DAP para a dose 1 (Figura 16) foi de 4.424,30 $\mathrm{gg}$ planta $^{-1}$ (138,26 $\mathrm{g} \mathrm{ha}^{-1}$ ) para uma produtividade de 19,7 $\mathrm{t} \mathrm{ha}^{-1}$, fracionado em $58,3 \%$ na parte aérea e $40 \%$ nas raízes. O máximo acúmulo de boro foi de 4.589,39 $\mu$ planta $^{-1}\left(143,42 \mathrm{~g} \mathrm{ha}^{-1}\right)$ para uma produtividade de $20,7 \mathrm{t} \mathrm{ha}^{-1}$ quando aplicado a dose 5 de $\mathrm{CO}_{2}\left(427,68 \mathrm{~kg} \mathrm{ha}^{-1}\right)$, fracionado em $62 \%$ na parte aérea e 36,5 nas raízes. Paula et al. (1986b) encontraram máximo acúmulo de boro de 22,2 e 12,4 $\mathrm{g}_{\text {ha }}{ }^{-1}$ nos cultivares Achat e Mantiqueira, respectivamente.

O acúmulo máximo de cobre total aos 103 DAP para a dose 1 foi de

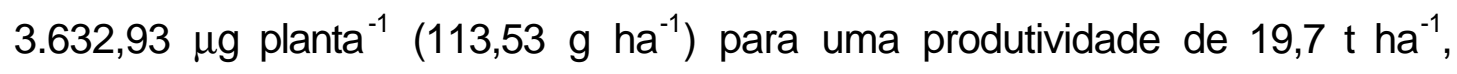
fracionado em $62,9 \%$ na parte aérea e $33,74 \%$ nas raízes. O máximo acúmulo de cobre foi de 5327,85 $\mu$ p planta $^{-1}\left(166,50 \mathrm{~g} \mathrm{ha}^{-1}\right)$ para uma produtividade de 22,03 t ha ${ }^{-1}$ quando aplicado a dose 2 de $\mathrm{CO}_{2}\left(205,5 \mathrm{~kg} \mathrm{ha}^{-1}\right)$, fracionado em $65 \%$ na parte aérea e $31 \%$ nas raízes. Paula et al. (1986b) observaram acúmulo máximo de cobre aos 86 DAE de 22,4 e $18 \mathrm{~g} \mathrm{ha}^{-1}$ nos cultivares Mantequeira e Achat, respectivamente.

O acúmulo máximo de ferro total aos 103 DAP para a dose 1 foi de $103.769,85 \mu \mathrm{g} \mathrm{planta}^{-1}\left(3242,81 \mathrm{~g} \mathrm{ha}^{-1}\right)$ para uma produtividade de 19,7 $\mathrm{t} \mathrm{ha}^{-1}$, fracionado em $58,25 \%$ na parte aérea e $25,59 \%$ nas raízes. O máximo acúmulo de ferro foi de $118.418,05 \mu$ planta $^{-1}\left(3702,75 \mathrm{~g} \mathrm{ha}^{-1}\right)$ para uma produtividade de $20,70 \mathrm{t} \mathrm{ha}^{-1}$ quando aplicado a dose 5 de $\mathrm{CO}_{2}\left(427,68 \mathrm{~kg} \mathrm{ha}^{-1}\right)$, fracionado em $59,06 \%$ na parte aérea e $28,30 \%$ nas raízes. No entanto, Paula et al. (1986b) encontraram valores de acúmulo de 710 e $760 \mathrm{~g} \mathrm{ha}^{-1}$ nos cv. Mantequeira e Achat, respectivamente.

O acúmulo máximo de manganês total aos 103 DAP para a dose 1 foi de 10.617,30 $\mathrm{mg}$ planta $^{-1}\left(331,79 \mathrm{~g} \mathrm{ha}^{-1}\right)$ para uma produtividade de 19,7 $\mathrm{t} \mathrm{ha}^{-1}$, fracionado em $85 \%$ na parte aérea e $10,26 \%$ nas raízes. O máximo acúmulo de 
manganês foi de $13.465,09 \mu \mathrm{g}_{\text {planta }}{ }^{-1}\left(420,78 \mathrm{~g} \mathrm{ha}^{-1}\right)$ para uma produtividade de $22,03 \mathrm{t} \mathrm{ha}^{-1}$ quando aplicado a dose 2 de $\mathrm{CO}_{2}\left(205,5 \mathrm{~kg} \mathrm{ha}^{-1}\right)$, fracionado em $84 \%$ na parte aérea e $8,6 \%$ nas raízes. Paula et al. (1986b) encontraram valores de acúmulo de 140 e $104 \mathrm{~g} \mathrm{ha}^{-1}$ nos cv. Mantequeira e Achat, respectivamente.

O acúmulo máximo de zinco total aos 103 DAP para a dose 1 foi de 5291 $\mu \mathrm{g}$ planta $^{-1}\left(165,34 \mathrm{~g} \mathrm{ha}^{-1}\right)$ para uma produtividade de $19,7 \mathrm{t} \mathrm{ha}^{-1}$, fracionado em $49,87 \%$ na parte aérea e $43,77 \%$ nas raízes. O máximo acúmulo de zinco foi de $6761,19 \mathrm{ug}$ planta $^{-1}\left(211,29 \mathrm{~g} \mathrm{ha}^{-1}\right)$ para uma produtividade de $22,03 \mathrm{t} \mathrm{ha}^{-1}$ quando aplicado a dose 2 de $\mathrm{CO}_{2}\left(205,5 \mathrm{~kg} \mathrm{ha}^{-1}\right)$, fracionado em $52,62 \%$ na parte aérea e 41,62\% nas raízes. Paula et al. (1986b) encontraram valores de acúmulo de 86 e $38 \mathrm{~g} \mathrm{ha}^{-1}$ nos cv. Mantequeira e Achat, respectivamente.

Após realizado a colheita do Experimento I, efetuou-se amostragem do solo por tratamento, cujo resultado é apresentado na Tabela 11, onde não existe variação significativa de $\mathrm{pH}$ com as diferentes concentrações de $\mathrm{CO}_{2}$ aplicados. Possivelmente ocorreu uma diminuição temporária de $\mathrm{pH}$ quando era aplicado $\mathrm{CO}_{2}$, para logo recuperar seu valor inicial, tal como indicam Storlie \& Heckman (1996). Observa-se também uma diminuição de matéria orgânica conforme o incremento de $\mathrm{CO}_{2}$, provavelmente porque o nitrogênio de solo ficou disponível e foi aproveitado pela planta, incrementando a biomassa da mesma (Stiling, et al,. 2003); a mesma tendência seguem os teores de $\mathrm{P}, \mathrm{Ke}$ Ca.

Tabela 11. Análise química de macronutientes do solo ao final do experimento I à profundidade de $0-20 \mathrm{~cm}$. Piracicaba, SP. 2001

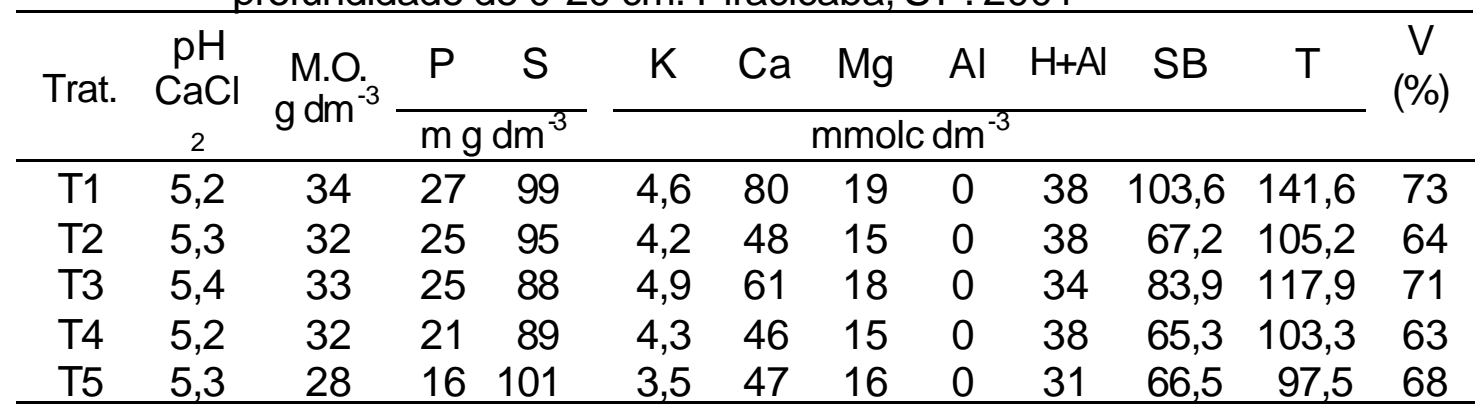


Também, pode-se observar na Tabela 12, redução nos teores de Fe, Mn e $\mathrm{Zn}$ conforme se incrementa a dose de $\mathrm{CO}_{2}$. Possivelmente, com o incremento de $\mathrm{CO}_{2} \circ \mathrm{pH}$ baixou temporariamente favorecendo a absorção dos micronutrientes tal como observado por Tognoni et al. (1967).

Tabela 12. Análise química de micronutrientes do solo ao final do experimento $\mathrm{I}$. à profundidade de $0-20 \mathrm{~cm}$. Piracicaba, SP. 2001

\begin{tabular}{cccccc}
\hline Trat. & $\mathrm{B}$ & $\mathrm{Cu}$ & $\mathrm{Fe}$ & $\mathrm{Mn}$ & $\mathrm{Zn}$ \\
\cline { 2 - 6 } & \multicolumn{5}{c}{$\left(\mathrm{mg} \mathrm{dm}^{-3}\right)$} \\
T1 & 0,97 & 8,6 & 40 & 95,2 & 3,4 \\
T2 & 0,67 & 7,8 & 37 & 86,6 & 3,1 \\
T3 & 0,70 & 8,3 & 37 & 92,6 & 3,1 \\
T4 & 0,90 & 8,5 & 38 & 83,6 & 3,3 \\
T5 & 0,64 & 7,1 & 28 & 71,4 & 2,7 \\
\hline
\end{tabular}

\subsubsection{Análise de Crescimento}

\subsubsection{Número de folhas}

A análise da variância mostrou que houve diferença significativa, pelo teste $\mathrm{F}$ entre o tempo de amostragem (Dias Após Emergência - DAE) ao nível de $1 \%$, não ocorrendo para as doses de $\mathrm{CO}_{2}$ nem para a interação. $O$ detalhamento da análise, pelo teste de Tukey, está apresentado na Tabela 13.

Tabela 13. Médias originais de número de folhas para o fator tratamento dentro do fator tempo

\begin{tabular}{|c|c|c|c|c|c|c|}
\hline \multicolumn{7}{|c|}{ Médias do tempo de amostragem } \\
\hline Tratamentos & 14 DAE & $28 \mathrm{DAE}$ & 42 DAE & 56 DAE & 70 DAE & $\begin{array}{l}\text { Médias de } \\
\text { tratamentos }\end{array}$ \\
\hline T1 & $79,63 a$ & $150,13 a$ & $155,25 a$ & 163,63a & $131,50 \mathrm{a}$ & $136,03 a$ \\
\hline T2 & $68,00 a$ & $126,13 a$ & $164,88 \mathrm{a}$ & $156,50 a$ & $147,88 a$ & $132,68 a$ \\
\hline T3 & $74,25 a$ & $150,50 a$ & $180,50 a$ & $158,00 a$ & $162,13 a$ & $145,08 a$ \\
\hline T4 & $85,75 a$ & $132,63 a$ & $206,50 \mathrm{a}$ & $138,50 a$ & $141,63 a$ & $141,00 a$ \\
\hline T5 & $73,13 a$ & $138,63 a$ & $173,75 a$ & $177,13 a$ & $178,88 a$ & $148,30 a$ \\
\hline Médias & $76,15 \mathrm{C}$ & $139,60 \mathrm{~B}$ & $176,18 A$ & 158,75AB & $152,40 \mathrm{AB}$ & \\
\hline
\end{tabular}

Médias seguidas por letras minúsculas iguais nas colunas e por letras maiúsculas nas linhas não diferem entre si pelo teste de Tukey ao nível de 5\% 
Verifica-se, quando comparados os tratamentos dentro do fator tempo de amostragem, que as menores médias de número de folhas encontram-se na amostragem aos 14 DAE. O maior número de folhas, independentes dos tratamentos, obteve-se aos $42 \mathrm{DAE}$, correspondendo ao estádio em que as plantas encontravam-se em pleno florescimento.

Comparando-se o fator tempo dentro dos tratamentos observa-se que não foi evidenciada diferença significativa entre os tratamentos em nenhuma das amostragens realizadas. A Figura 17 permite visualizar a equação de regressão média das curvas.

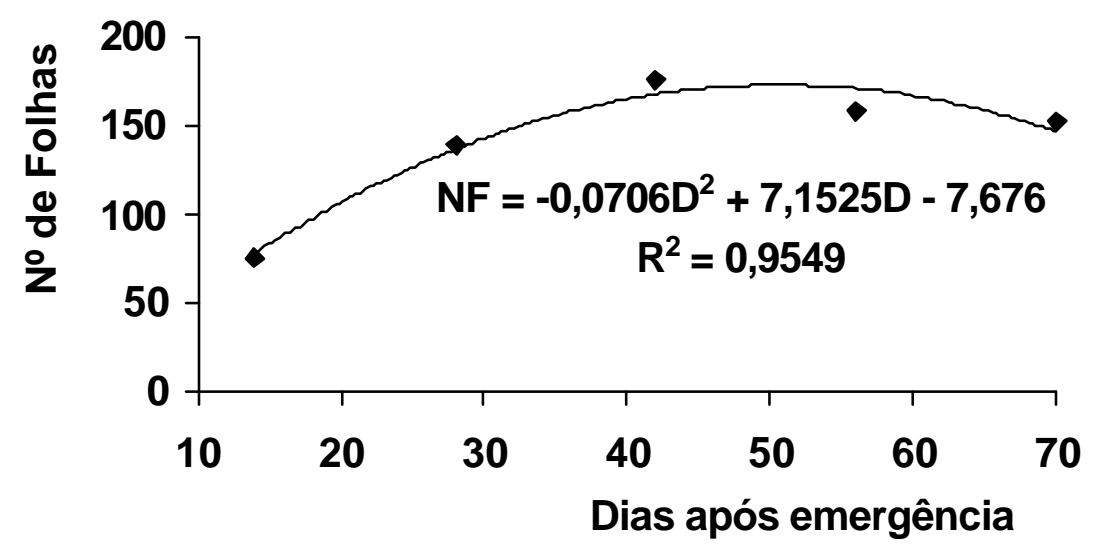

Figura 17 - Curva de médias de tratamentos e equação de regressão entre o número de folhas e os períodos de avaliação com as doses: D1=0; D2=205,2; D3=279,36; D4=353,52; D5=427,68 $\mathrm{kg} \mathrm{ha}^{-1}$ de $\mathrm{CO}_{2}$

\subsubsection{Número de estolões}

O quadro de análise da variância mostrou que houve diferença significativa, pelo teste $\mathrm{F}$, entre o tempo de amostragem (DAE) ao nível de $1 \%$, não ocorrendo para as doses de $\mathrm{CO}_{2}$ nem para a interação. $\mathrm{O}$ detalhamento da análise, pelo teste de Tukey, é apresentado na Tabela 14. 
Tabela 14. Médias originais do número de estolões para o fator tratamento dentro do fator tempo de amostragem

\begin{tabular}{ccccccc}
\hline \multicolumn{7}{c}{ Médias do Tempo de amostragem } \\
Tratamentos & 14 DAE & 28DAE & 42 DAE & 56 DAE & 70 DAE & Médias de \\
& & & & & & tratamentos \\
\hline T1 & $20,75 a$ & $9,38 a$ & $16,13 a$ & $8,88 a$ & $7,38 a$ & $\mathbf{1 2 , 5 0 a}$ \\
T2 & $23,13 a$ & $15,75 a$ & $16,75 a$ & $9,25 a$ & $6,13 a$ & $\mathbf{1 4 , 2 0 a}$ \\
T3 & $21,25 a$ & $14,75 a$ & $14,50 a$ & $7,75 a$ & $7,38 a$ & $\mathbf{1 3 , 1 3 a}$ \\
T4 & $18,88 a$ & $15,25 a$ & $17,75 a$ & $8,63 a$ & $9,13 a$ & $\mathbf{1 3 , 9 3 a}$ \\
T5 & $18,25 a$ & $9,75 a$ & $14,50 a$ & $8,00 a$ & $6,25 a$ & $\mathbf{1 1 , 3 5 a}$ \\
Médias & $\mathbf{2 0 , 4 5 A}$ & $\mathbf{1 2 , 9 8 B C}$ & $\mathbf{1 5 , 9 3 A B}$ & $\mathbf{8 , 5 0 C D}$ & $\mathbf{7 , 2 5 D}$ & \\
\hline
\end{tabular}

Médias seguidas por letras minúsculas iguais nas colunas e por letras maiúsculas nas linhas não diferem entre si pelo teste de Tukey ao nível de $5 \%$

Verifica-se na Tabela 14 que as menores médias de número de estolões, quando comparadas às doses de $\mathrm{CO}_{2}$ dentro do tempo de amostragem, são encontradas aos $70 \mathrm{DAE}$, independente dos tratamentos, possivelmente porque a maioria dos estolões da planta já tinham se transformado em tubérculos, devido à aproximação do último estádio de crescimento. As maiores médias de número de estolões foram encontradas aos $14 \mathrm{DAE}$ independente das doses de $\mathrm{CO}_{2}$, período que corresponde ao inicio de formação de estolões.

Quando comparados o fator tempo dentro dos tratamentos observa-se que não foi evidenciada diferença significativa entre os tratamentos em nenhuma das amostragens realizadas.

\subsubsection{Número de tubérculos}

O quadro da análise da variância mostrou que houve diferença significativa, pelo teste $\mathrm{F}$, entre o tempo de amostragem (DAE) ao nível de $1 \%$, não ocorrendo para as doses de $\mathrm{CO}_{2}$ nem para a interação. $\mathrm{O}$ detalhamento da análise, pelo teste de Tukey, é apresentado na Tabela 15. 
Tabela 15. Médias originais de número de tubérculos para o fator tratamento dentro do fator tempo de amostragem

\begin{tabular}{cccccc}
\hline \multicolumn{5}{c}{ Médias do Tempo de amostragem } \\
Tratamentos & 28 DAE & 42 DAE & 56 DAE & 70 DAE & Médias de \\
& & & & & tratamentos \\
\hline T1 & $10,62 \mathrm{a}$ & $16,62 \mathrm{a}$ & $14,50 \mathrm{a}$ & $15,38 \mathrm{a}$ & $\mathbf{1 4 , 2 8 a}$ \\
T2 & $11,12 \mathrm{a}$ & $16,62 \mathrm{a}$ & $16,25 \mathrm{a}$ & $17,75 \mathrm{a}$ & $\mathbf{1 5 , 4 3 a}$ \\
T3 & $14,00 \mathrm{a}$ & $17,50 \mathrm{a}$ & $13,50 \mathrm{a}$ & $17,38 \mathrm{a}$ & $\mathbf{1 5 , 5 9 a}$ \\
T4 & $13,12 \mathrm{a}$ & $17,75 \mathrm{a}$ & $14,12 \mathrm{a}$ & $14,75 \mathrm{a}$ & $\mathbf{1 4 , 9 4 a}$ \\
T5 & $12,50 \mathrm{a}$ & $18,62 \mathrm{a}$ & $18,25 \mathrm{a}$ & $17,25 \mathrm{a}$ & $\mathbf{1 6 , 6 5 a}$ \\
Médias & $\mathbf{1 2 , 2 7 B}$ & $\mathbf{1 7 , 4 2 A}$ & $\mathbf{1 5 , 3 7 A B}$ & $\mathbf{1 6 , 5 0 A}$ & \\
\hline
\end{tabular}

Médias seguidas por letras minúsculas iguais nas colunas e por letras maiúsculas nas linhas não diferem entre si pelo teste de Tukey ao nível de 5\%

Verifica-se na Tabela 15 que as menores médias de número de tubérculos, quando comparadas as doses de $\mathrm{CO}_{2}$ dentro do tempo de amostragem, foram encontradas aos $28 \mathrm{DAE}$, independente dos tratamentos, possivelmente porque ainda estavam se transformando em tubérculos, não diferindo significativamente do número de tubérculos avaliados aos 56 DAE. As maiores médias de número de tubérculos foram encontradas aos 42 e 70 DAE, respectivamente, não diferindo significativamente entre si, nem com os avaliados aos 56 DAE.

Quando comparados o fator tempo dentro dos tratamentos observa-se que não foi evidenciada diferença significativa entre os tratamentos em nenhuma das amostragens realizadas.

A Figura 18 ilustra o comportamento de número de estolões e número de tubérculos assim como as equações de regressão para a média dos tratamentos em função das amostragens realizadas. 


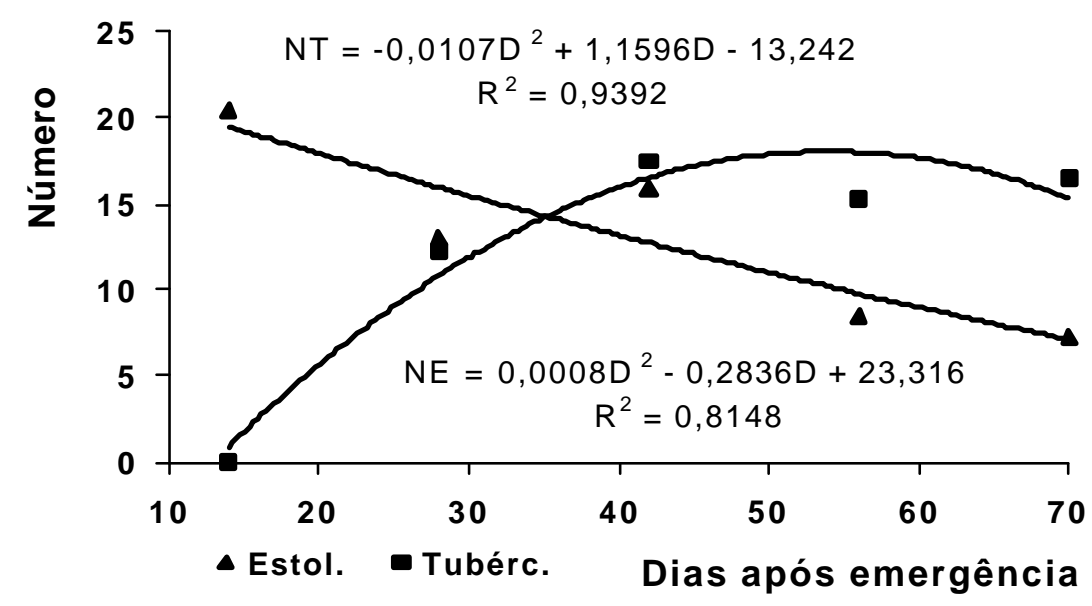

Figura 18 - Curvas de médias dos tratamentos e equações de regressão do número de estolões e tubérculos em função dos períodos de amostragem

\subsubsection{4 Área foliar}

A análise da variância mostrou que houve diferença significativa, pelo teste $\mathrm{F}$ entre o tempo de amostragem (DAE) ao nível de 1\%, não ocorrendo para as doses de $\mathrm{CO}_{2}$ nem para a interação. O detalhamento da análise, pelo teste de Tukey, está apresentado na Tabela 16.

Tabela 16. Médias originais de área foliar $\left(\mathrm{dm}^{2}\right)$ para o fator tratamento dentro do fator tempo de amostragem

\begin{tabular}{|c|c|c|c|c|c|c|}
\hline \multicolumn{7}{|c|}{ Médias do tempo de amostragem } \\
\hline Tratamentos & 14 DAE & 28 DAE & 42 DAE & 56 DAE & 70 DAE & $\begin{array}{l}\text { Medias de } \\
\text { tratamentos }\end{array}$ \\
\hline $\mathrm{T} 1$ & $25,53 a$ & $106,77 a$ & $111,95 a$ & $118,10 a$ & $74,30 a$ & $87,33 a$ \\
\hline T2 & $28,33 a$ & $89,65 a$ & $135,92 a$ & $118,45 a$ & $93,25 a$ & $93,12 a$ \\
\hline T3 & $22,98 a$ & $104,32 a$ & $145,32 a$ & $112,95 a$ & $92,72 a$ & $95,66 a$ \\
\hline T4 & $24,68 a$ & $91,55 a$ & $165,13 a$ & $100,28 a$ & $80,18 a$ & $92,36 a$ \\
\hline T5 & & & $135,80 a$ & $140,00 a$ & $99,42 a$ & $100,34 a$ \\
\hline Médias & 26,12D & 97,94BC & $138,82 A$ & $117,96 \mathrm{~B}$ & $87,98 \mathrm{C}$ & \\
\hline
\end{tabular}

Médias seguidas por letras minúsculas iguais nas colunas e por letras maiúsculas nas linhas não diferem entre si pelo teste de Tukey ao nível de $5 \%$ 
Verifica-se que as menores médias de área foliar encontram-se na amostragem aos $14 \mathrm{DAE}$, quando comparados as doses e $\mathrm{CO}_{2}$ dentro do fator tempo de amostragem, o que coincide com o menor número de folhas mostrada na Tabela 13. O maior valor de área foliar, independente dos tratamentos, foi obtido aos $42 \mathrm{DAE}$, tendo uma correlação direta com o maior número de folhas aos 42 DAE mostrada na Tabela 13.

Comparando-se o fator tempo de amostragem dentro dos tratamentos observa-se que não foi evidenciada diferença significativa entre os tratamentos em nenhuma das amostragens realizadas.

A Figura 19 permite visualizar a equação de regressão média dos tratamentos em função das amostragens realizadas.

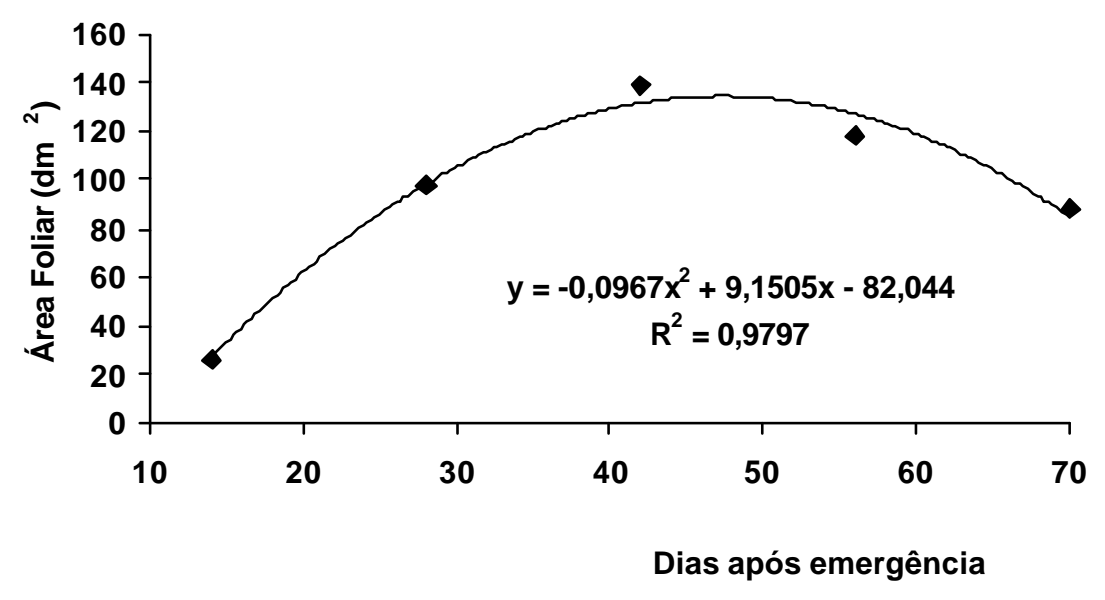

Figura 19 - Curva das médias dos tratamentos e equação de regressão entre a área foliar e os períodos de avaliação

\subsubsection{Massa seca da parte aérea}

O quadro da análise da variância mostrou que houve diferença significativa, pelo teste $F$, entre o tempo de amostragem (DAE) ao nível de 1\%, 
não ocorrendo para as doses de $\mathrm{CO}_{2}$ nem para a interação. O detalhamento da análise, pelo teste de Tukey, está apresentado na Tabela 17.

Tabela 17. Médias originais de massa seca $(\mathrm{g})$ da parte aérea para o fator tratamento dentro do fator tempo de amostragem

Médias do tempo de amostragem

\begin{tabular}{ccccccc} 
Tratamentos & 14 DAE & 28 DAE & 42 DAE & 56 DAE & 70 DAE & $\begin{array}{c}\text { Médias de } \\
\text { tratamentos }\end{array}$ \\
\hline T1 & $11,31 a$ & $53,22 a$ & $53,10 a$ & $54,72 a$ & $58,63 a$ & $\mathbf{4 6 , 2 0 a}$ \\
T2 & $13,11 a$ & $50,28 \mathrm{a}$ & $62,79 a$ & $60,73 a$ & $71,15 a$ & $\mathbf{5 1 , 6 1 a}$ \\
T3 & $12,12 \mathrm{a}$ & $53,06 \mathrm{a}$ & $68,35 \mathrm{a}$ & $59,07 \mathrm{a}$ & $63,10 \mathrm{a}$ & $\mathbf{5 1 , 1 4 a}$ \\
T4 & $12,46 \mathrm{a}$ & $51,99 \mathrm{a}$ & $83,54 \mathrm{a}$ & $60,63 \mathrm{a}$ & $61,53 \mathrm{a}$ & $\mathbf{5 4 , 0 3 a}$ \\
T5 & $13,94 \mathrm{a}$ & $50,22 \mathrm{a}$ & $70,49 \mathrm{a}$ & $66,55 \mathrm{a}$ & $67,75 \mathrm{a}$ & $\mathbf{5 3 , 7 9 a}$ \\
Médias & $\mathbf{1 2 , 5 9 \mathrm { C }}$ & $\mathbf{5 1 , 7 5 B}$ & $\mathbf{6 7 , 6 5 A}$ & $\mathbf{6 0 , 3 4 A B}$ & $\mathbf{6 4 , 4 3 A}$ & \\
\hline
\end{tabular}

Médias seguidas por letras minúsculas iguais nas colunas e por letras maiúsculas nas linhas não diferem entre si pelo teste de Tukey ao nível de $5 \%$

Verifica-se na Tabela 17 que as menores médias de massa seca da parte aérea, quando comparadas às doses de $\mathrm{CO}_{2}$ dentro do tempo de amostragem, são encontradas aos 14 DAE, independente dos tratamentos, como conseqüência de ter apresentado as menores médias de número de folhas também aos 14 DAE. As maiores médias de massa seca da parte aérea foram encontradas aos 42 e $70 \mathrm{DAE}$, independente das doses de $\mathrm{CO}_{2}$.

Observa-se que não foi evidenciada diferença significativa entre os tratamentos em nenhuma das amostragens realizadas quando comparados 0 fator tempo de amostragem dentro dos tratamentos.

A Figura 20 ilustra as curvas das médias dos tratamentos em função das amostragens realizadas. 


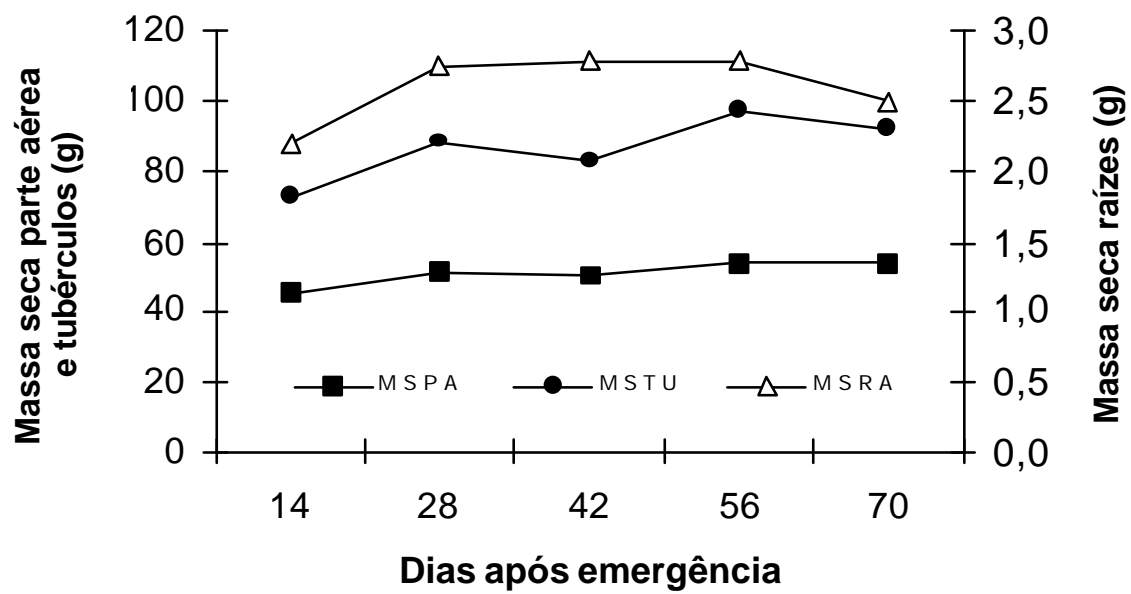

Figura 20 - Curvas das médias de tratamento de: MSPA (Massa Seca da Parte Aérea), MSRA (Massa Seca das Raízes) e MSTU (Massa Seca dos Tubérculos) em função dos períodos de avaliação.

\subsubsection{Massa seca de raízes}

A análise da variância mostrou que houve diferença significativa, pelo teste $F$, entre o tempo de amostragem (DAE) ao nível de 1\%, não ocorrendo para as doses de $\mathrm{CO}_{2}$ nem para a interação. $\mathrm{O}$ detalhamento da análise, por meio do teste de Tukey, está apresentado na Tabela 18.

Tabela 18. Médias originais de massa seca ( $\mathrm{g}$ ) de raízes para o fator tratamento dentro do fator tempo de amostragem

\begin{tabular}{ccccccc}
\hline \multirow{7}{*}{ Tratamentos } & \multicolumn{5}{c}{ Médias do tempo de amostragem } & \multirow{2}{*}{ Médias de } \\
& 14 DAE & 28 DAE & 42 DAE & 56 DAE & 70 DAE & tratamentos \\
\hline T1 & $1,52 \mathrm{a}$ & $4,15 \mathrm{a}$ & $2,94 \mathrm{a}$ & $2,55 \mathrm{a}$ & $2,74 \mathrm{a}$ & $\mathbf{2 , 7 8 a}$ \\
T2 & $1,77 \mathrm{a}$ & $4,06 \mathrm{a}$ & $3,76 \mathrm{a}$ & $3,00 \mathrm{a}$ & $3,45 \mathrm{a}$ & $\mathbf{3 , 2 1 a}$ \\
T3 & $1,81 \mathrm{a}$ & $4,47 \mathrm{a}$ & $3,75 \mathrm{a}$ & $3,05 \mathrm{a}$ & $2,86 \mathrm{a}$ & $\mathbf{3 , 1 9 a}$ \\
T4 & $1,81 \mathrm{a}$ & $4,48 \mathrm{a}$ & $4,20 \mathrm{a}$ & $2,88 \mathrm{a}$ & $2,95 \mathrm{a}$ & $\mathbf{3 , 2 6 a}$ \\
T5 & 1,88a & $3,67 \mathrm{a}$ & $3,39 \mathrm{a}$ & 3,08a & $2,93 \mathrm{a}$ & $\mathbf{2 , 9 9 a}$ \\
Médias & $\mathbf{1 , 7 6 \mathrm { D }}$ & $\mathbf{4 , 1 6 A}$ & $\mathbf{3 , 6 1 A B}$ & $\mathbf{2 , 9 1 C}$ & $\mathbf{2 , 9 9 B C}$ & \\
\hline
\end{tabular}

Médias seguidas por letras minúsculas iguais nas colunas e por letras maiúsculas nas linhas não diferem entre si pelo teste de Tukey ao nível de $5 \%$ 
Verifica-se, quando comparados às doses de $\mathrm{CO}_{2}$ dentro do fator tempo de amostragem, que as menores médias de massa seca de raízes foi encontrado na amostragem dos 14 DAE, devido a encontrar-se no início de seu desenvolvimento. $O$ maior valor de massa seca de raízes, independente dos tratamentos, obteve-se aos $28 \mathrm{DAE}$, seguido aos $42 \mathrm{DAE}$. A Figura 20 permite visualizar melhor esse resultado.

Comparando-se o fator tempo de amostragem dentro dos ratamentos observa-se que não foi evidenciada diferença significativa entre os tratamentos em nenhuma das amostragens realizadas. Entretanto, pode-se observar um suave incremento de massa seca aos $42 \mathrm{DAE}$ com o aumento da dosagem de $\mathrm{CO}_{2}$. Possivelmente ocorreu um aumento no crescimento do sistema radicular, estimulado pela inibição de etileno, como indica Baker, (1988).

\subsubsection{Massa seca de tubérculos}

O quadro de análise da variância mostrou que houve diferença significativa, pelo teste $F$, entre o tempo de amostragem (DAE) ao nível de $1 \%$, não ocorrendo para as doses de $\mathrm{CO}_{2}$ nem para a interação. $\mathrm{O}$ detalhamento da análise, por meio do teste de Tukey, está apresentado na Tabela 19.

Tabela 19. Médias originais de massa seca $(\mathrm{g})$ de tubérculos para o fator tratamento dentro do fator tempo de amostragem

\begin{tabular}{|c|c|c|c|c|c|}
\hline \multirow[b]{2}{*}{ Tratamentos } & \multicolumn{4}{|c|}{ Médias do tempo de amostragem } & \multirow[b]{2}{*}{$\begin{array}{l}\text { Médias de } \\
\text { tratamentos }\end{array}$} \\
\hline & 28 DAE & 42 DAE & 56 DAE & 70 DAE & \\
\hline $\mathrm{T} 1$ & $14,74 a$ & $45,89 a$ & $89,97 a$ & $136,20 a$ & 71,70a \\
\hline $\mathrm{T} 2$ & $21,66 a$ & $47,90 \mathrm{a}$ & $124,35 a$ & $165,52 a$ & $89,86 a$ \\
\hline T3 & $15,52 a$ & $64,57 a$ & $122,40 a$ & $132,75 a$ & $83,81 a$ \\
\hline $\mathrm{T} 4$ & $15,04 a$ & $76,34 a$ & $130,35 a$ & $166,82 a$ & $97,14 a$ \\
\hline T5 & $16,04 a$ & $63,47 a$ & $124,35 a$ & $167,65 a$ & $92,88 a$ \\
\hline
\end{tabular}


Médias seguidas por letras minúsculas iguais nas colunas e por letras maiúsculas nas linhas não diferem entre si pelo teste de Tukey ao nível de $5 \%$

Verifica-se na Tabela 19 que as menores médias de massa seca de tubérculos são encontradas aos 28 DAE quando comparadas as doses de $\mathrm{CO}_{2}$ dentro do tempo de amostragem, independente dos tratamentos e considerando que na primeira amostragem, correspondente aos $14 \mathrm{DAE}$, ainda não havia formação de tubérculos, razão pela qual esta amostragem não foi contemplada na análise estatística. As maiores médias de massa seca de tubérculos foram encontradas aos $70 \mathrm{DAE}$, independente das doses de $\mathrm{CO}_{2}$.

Quando comparados o fator tempo de amostragem dentro dos tratamentos, observa-se que não houve diferença significativa entre os tratamentos em nenhuma das amostragens realizadas.

\subsubsection{8 Índice de área foliar}

A análise da variância mostrou que houve diferença significativa, pelo teste $\mathrm{F}$, entre o tempo de amostragem (DAE) ao nível de 1\%, não ocorrendo para as doses de $\mathrm{CO}_{2}$ nem para a interação. $\mathrm{O}$ detalhamento da análise, por meio do teste de Tukey, está apresentado na Tabela 20.

Tabela 20. Médias originais do índice de área foliar para o fator tratamento dentro do fator tempo de amostragem

\begin{tabular}{ccccccc}
\hline \multicolumn{7}{c}{ Médias do tempo de amostragem } \\
Tratamentos & 14 DAE & 28 DAE & 42 DAE & 56 DAE & 70 DAE & Médias de \\
tratamentos
\end{tabular}

Médias seguidas por letras minúsculas iguais nas colunas e por letras maiúsculas nas linhas não diferem entre si pelo teste de Tukey ao nível de $5 \%$ 
Verifica-se, quando comparados os tratamentos dentro do fator tempo de amostragem, que as menores médias do índice de área foliar encontram-se na amostragem aos 14 DAE. O maior índice de área foliar, independente dos tratamentos, obteve-se aos 42 DAE coincidindo com a maior área foliar obtida também aos $42 \mathrm{DAE}$, revelando assim, maior cobertura pelas folhas na área disponível do solo.

Comparando-se o fator tempo dentro dos tratamentos observa-se que não foi evidenciada diferença significativa entre os tratamentos em nenhuma das amostragens realizadas.

A Figura 21 permite visualizar a equação de regressão da média dos tratamentos em função das amostragens realizadas.

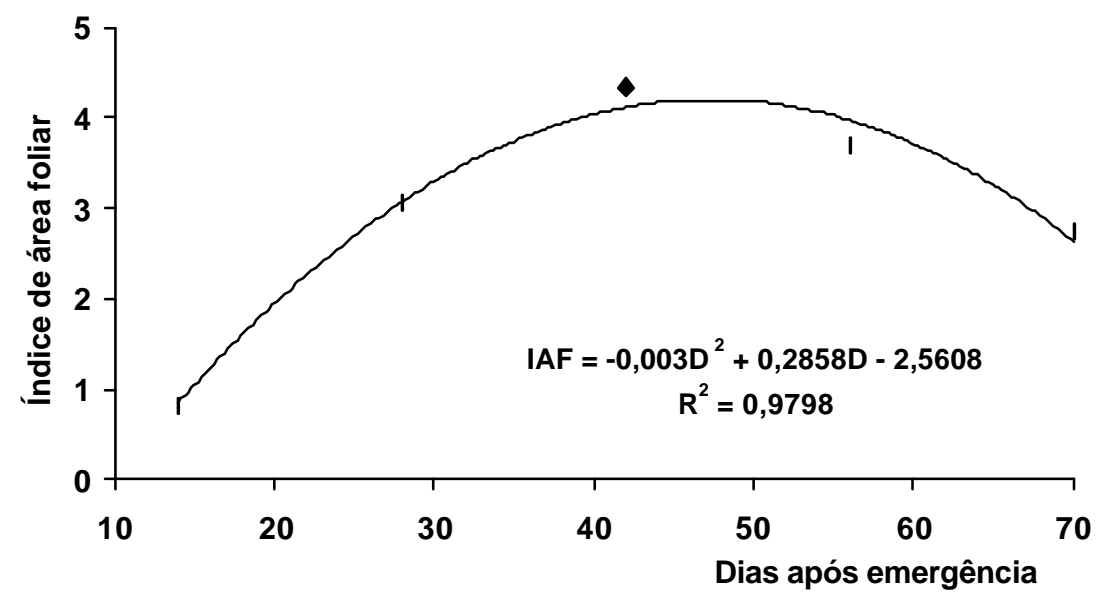

Figura 21 - Curva das médias de tratamento e equação de regressão entre o índice de área foliar e os períodos de avaliação

\subsubsection{Relação parte aérea/raízes}

O quadro de análise da variância mostrou que houve diferença significativa, pelo teste $\mathrm{F}$, entre o tempo de amostragem (DAE) ao nível de $1 \%$, 
não ocorrendo para as doses de $\mathrm{CO}_{2}$ nem para a interação. $\mathrm{O}$ detalhamento da análise, pelo teste de Tukey, está apresentado na Tabela 21.

Tabela 21. Médias originais da relação parte aérea/raízes para o fator tratamento dentro do fator tempo de amostragem

\begin{tabular}{ccccccc}
\hline \multicolumn{7}{c}{ Médias do tempo de amostragem } \\
Tratamentos & 14 DAE & 28 DAE & 42 DAE & 56 DAE & 70 DAE & Médias de \\
& & & & & tratamentos \\
\hline T1 & $7,45 a$ & $13,69 a$ & $18,20 a$ & $22,14 a$ & $21,48 a$ & $\mathbf{1 6 , 5 9 a}$ \\
T2 & $7,52 a$ & $12,42 a$ & $17,08 a$ & $20,37 a$ & $21,10 a$ & $\mathbf{1 5 , 7 0 a}$ \\
T3 & $7,06 a$ & $11,82 a$ & $18,48 a$ & $19,97 a$ & $23,03 a$ & $\mathbf{1 6 , 0 7 a}$ \\
T4 & $6,72 a$ & $11,50 a$ & $19,78 a$ & $21,61 a$ & $20,95 a$ & $\mathbf{1 6 , 1 1 a}$ \\
T5 & $7,42 a$ & $13,75 a$ & $21,25 a$ & $22,96 a$ & $25,35 a$ & $\mathbf{1 8 , 1 5 a}$ \\
Médias & 7,23D & $\mathbf{1 2 , 6 4 C}$ & $\mathbf{1 8 , 9 6 B}$ & $\mathbf{2 1 , 4 1 A B}$ & $\mathbf{2 2 , 3 8 A}$ & \\
\hline
\end{tabular}

Médias seguidas por letras minúsculas iguais nas colunas e por letras maiúsculas nas linhas não diferem entre si pelo teste de Tukey ao nível de $5 \%$

Verifica-se na Tabela 21 que as menores médias da relação parte aérea/raízes foram encontradas aos $14 \mathrm{DAE}$, quando comparadas as doses de $\mathrm{CO}_{2}$ dentro do tempo de amostragem, independente dos tratamentos. As maiores médias da relação parte aérea/raízes foram encontradas aos 70 DAE, independente das doses de $\mathrm{CO}_{2}$, indicando que o desenvolvimento da parte aérea foi muito maior que o do sistema radicular no último estádio.

Quando comparados o fator tempo de amostragem dentro dos tratamentos observa-se que não foi evidenciada diferença significativa entre os tratamentos em nenhuma das amostragens realizadas.

A Figura 22 permite visualizar a equação de regressão da média dos tratamentos em função às amostragens realizadas. 


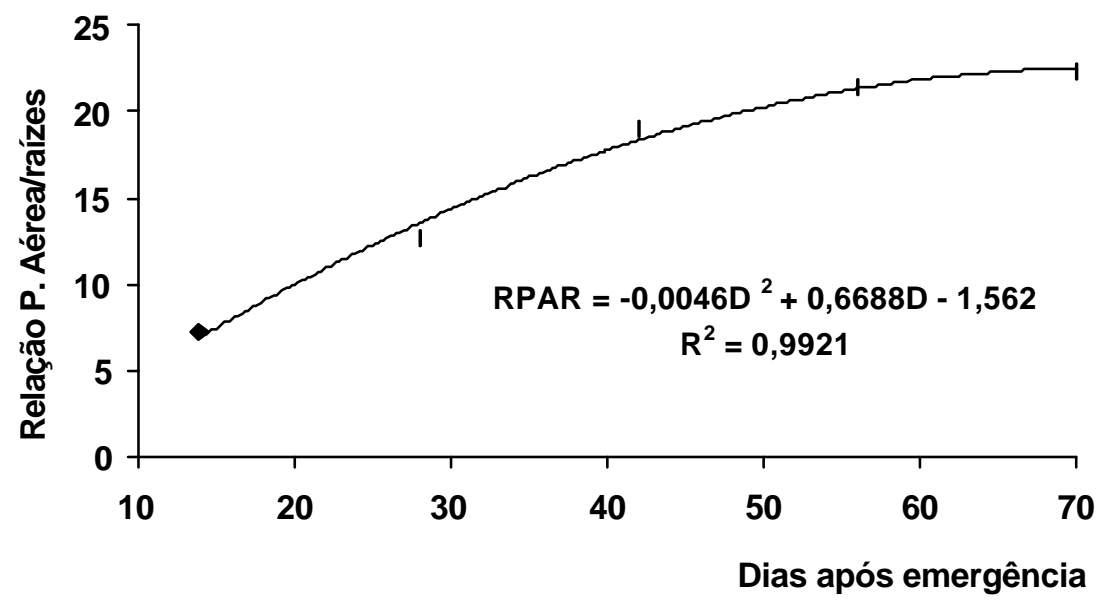

Figura 22 - Curva das médias de tratamento e equação de regressão entre a relação da parte aérea/raízes e os períodos de avaliação

\subsubsection{Razão de área foliar}

A análise da variância mostrou que houve diferença significativa, pelo teste $\mathrm{F}$, entre o tempo de amostragem (DAE) ao nível de 1\%, não ocorrendo para as doses de $\mathrm{CO}_{2}$ nem para a interação. O detalhamento da análise, pelo teste de Tukey, está apresentado na Tabela 22.

Tabela 22. Médias originais da razão de área foliar $\left(\mathrm{dm}^{2} \mathrm{~g}^{-1}\right)$ para o fator tratamento dentro do fator tempo de amostragem

\begin{tabular}{ccccccc}
\hline \multicolumn{7}{c}{ Médias do tempo de amostragem } \\
Tratamentos & 14 DAE & 28DAE & 42 DAE & 56 DAE & 70 DAE & $\begin{array}{c}\text { Médias de } \\
\text { tratamentos }\end{array}$ \\
\hline T1 & $1,79 a$ & $1,50 a$ & $1,06 a$ & $0,79 a$ & $0,39 a$ & $\mathbf{1 , 1 1 a}$ \\
T2 & $1,87 a$ & $1,17 a$ & $1,19 a$ & $0,67 a$ & $0,38 a$ & $\mathbf{1 , 0 5 a}$ \\
T3 & $1,60 a$ & $1,46 a$ & $1,11 a$ & $0,61 a$ & $0,49 a$ & $\mathbf{1 , 0 5 a}$ \\
T4 & $1,71 a$ & $1,25 a$ & $1,07 a$ & $0,54 a$ & $0,35 a$ & $\mathbf{0 , 9 8 a}$ \\
T5 & $1,79 a$ & $1,41 a$ & $0,99 a$ & $0,73 a$ & $0,43 a$ & $\mathbf{1 , 0 7 a}$ \\
Médias & $\mathbf{1 , 7 5 A}$ & $\mathbf{1 , 3 6 B}$ & $\mathbf{1 , 0 8 C}$ & $\mathbf{0 , 6 7 D}$ & $\mathbf{0 , 4 1 E}$ & \\
\hline
\end{tabular}

Médias seguidas por letras minúsculas iguais nas colunas e por letras maiúsculas nas linhas não diferem entre si pelo teste de Tukey ao nível de $5 \%$ 
Verifica-se, quando comparados os tratamentos dentro do fator tempo de amostragem, que as menores médias da razão de área foliar encontram-se na amostragem aos 70 DAE. A maior razão de área foliar, independente dos tratamentos, obteve-se aos $14 \mathrm{DAE}$, devido ao incremento da massa seca da planta durante o ciclo da cultura, sendo os tubérculos o principal contribuinte para o incremento desta massa, apesar do incremento da área foliar.

Comparando-se o fator tempo de amostragem dentro dos tratamentos observa-se que não houve diferença significativa entre os tratamentos em nenhuma das amostragens realizadas.

A Figura 23 permite visualizar a equação de regressão da média das doses de $\mathrm{CO}_{2}$ aplicada em função das amostragens realizadas.

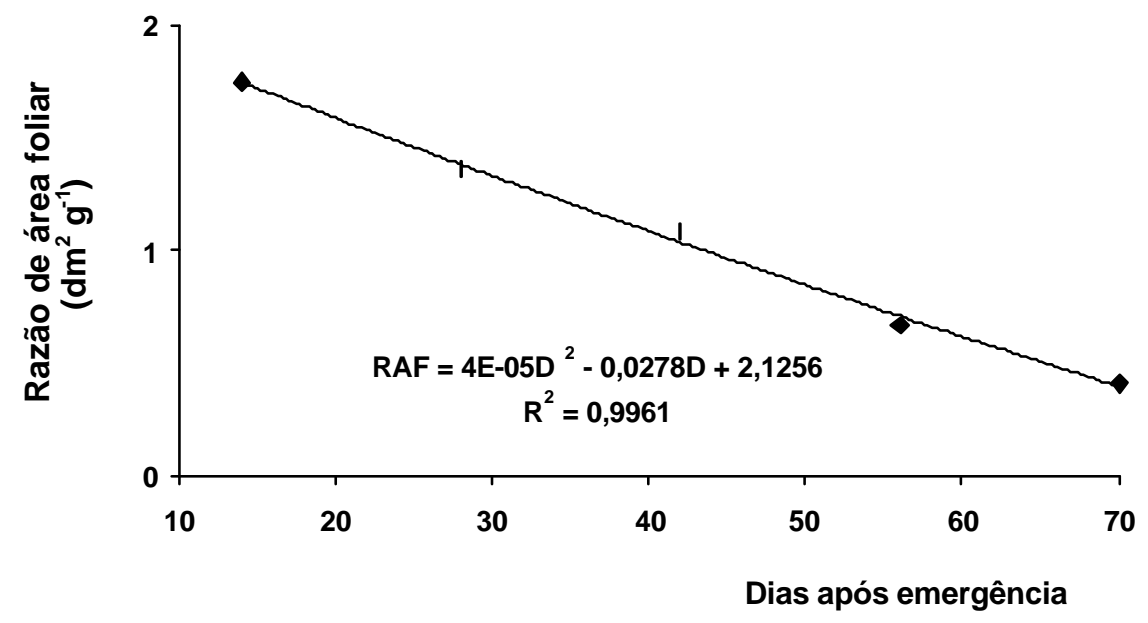

Figura 23 - Curva das médias de tratamento e equação de regressão entre razão de área foliar e os períodos de avaliação

A Figura 24 apresenta a taxa de crescimento relativo obtida entre os períodos de amostragem nos diferentes tratamentos de $\mathrm{CO}_{2}$, que representa o crescimento da planta em termos de matéria seca formada por unidade de tempo, em função da massa inicial. Observa-se incremento de matéria seca até o segundo período (correspondente à terceira menos a segunda amostragem) e o 
subseqüente declínio no intervalo de tempo de amostragem. Dentro das dosagens de $\mathrm{CO}_{2}$, evidenciourse um maior crescimento da planta em termos de matéria seca com $353,52 \mathrm{~kg} \mathrm{ha}^{-1}$ de $\mathrm{CO}_{2}$, no segundo período, para logo cair nos subseqüentes períodos. Nas demais dosagens não houve uma diferença marcante.

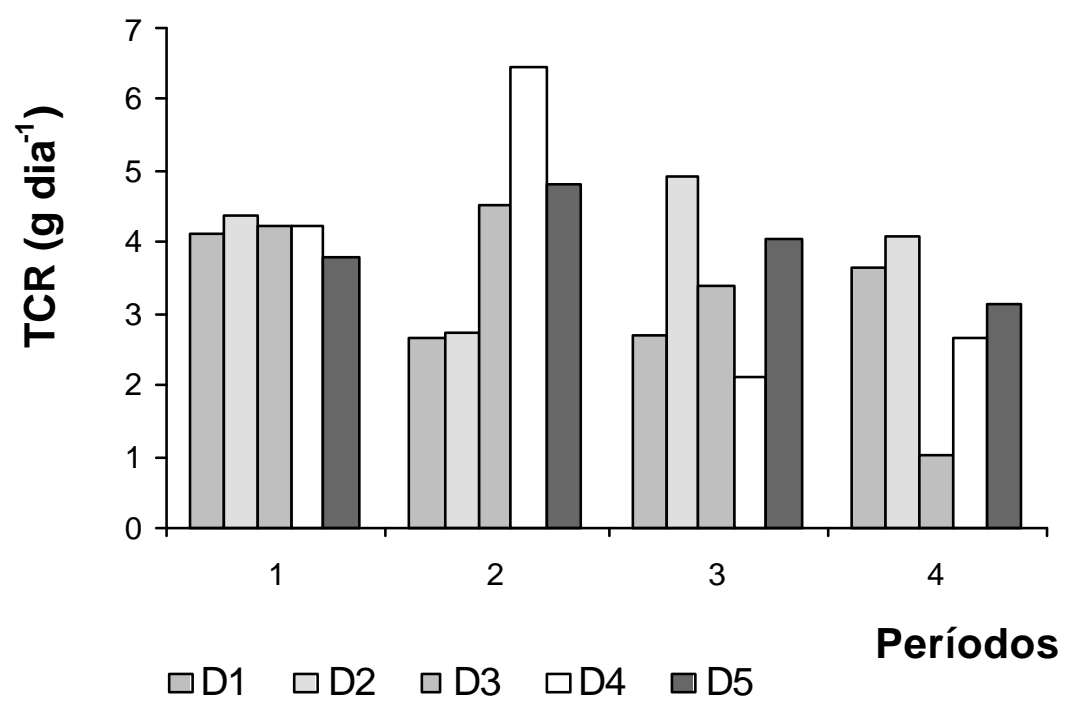

Figura 24 - Taxa de crescimento relativo na batateira em função dos períodos de amostragem com as doses: D1=0; $\quad \mathrm{D} 2=205,2 ; \quad \mathrm{D} 3=279,36$; $\mathrm{D} 4=353,52 ; \mathrm{D} 5=427,68 \mathrm{~kg} \mathrm{ha}^{-1}$ de $\mathrm{CO}_{2}$

A Figura 25 apresenta a taxa de produção de matéria seca obtida entre os períodos de amostragem e os diferentes tratamentos de $\mathrm{CO}_{2}$. 


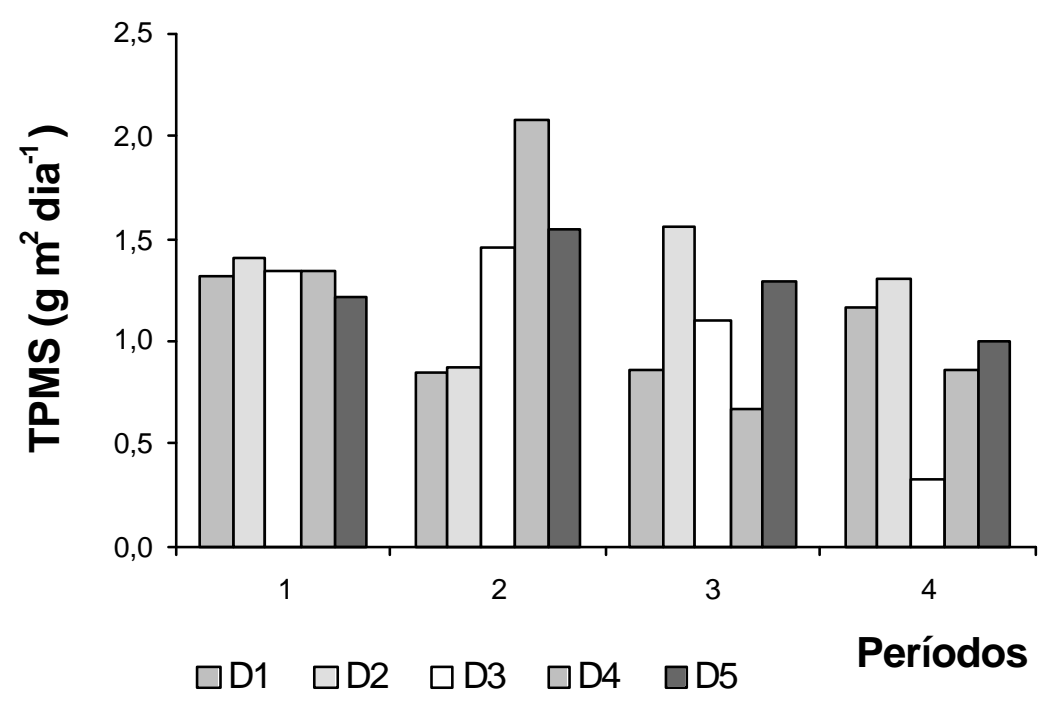

Figura 25 - Taxa de produção de matéria seca na batateira em função dos períodos de amostragem com as doses: D1=0; D2=205,2; D3=279,36; D4=353,52; D5=427,68 $\mathrm{kg} \mathrm{ha}^{-1}$ de $\mathrm{CO}_{2}$

Como conseqüência da maior área foliar na terceira amostragem, obteve-se também maior taxa de produção de matéria seca no segundo período. Com respeito às dosagens de $\mathrm{CO}_{2}$, obteve-se maior taxa de produção de matéria seca no segundo período aplicando-se $353,52 \mathrm{~kg} \mathrm{ha}^{-1}$ de $\mathrm{CO}_{2}$.

\subsubsection{Produtividade total de tubérculos}

O quadro de análise da variância mostrou que não houve diferença significativa, pelo teste $\mathrm{F}$, entre os níveis de $\mathrm{CO}_{2}$ ao nível de $1 \%$, para a produtividade total de tubérculos. $O$ detalhamento da análise, pelo teste de Tukey, está apresentado na Tabela 23. 
Tabela 23. Médias originais de produtividade total em função das doses de $\mathrm{CO}_{2}$

\begin{tabular}{cc}
\hline Tratamentos & $\begin{array}{c}\text { Médias Originais } \\
\text { Produtividade }\left(\mathbf{t ~ h a}^{-1}\right)\end{array}$ \\
\hline T1 & $19,70 \mathrm{a}$ \\
T2 & $22,03 \mathrm{a}$ \\
T3 & $21,21 \mathrm{a}$ \\
T4 & $19,89 \mathrm{a}$ \\
T5 & $20,70 \mathrm{a}$ \\
\hline
\end{tabular}

Médias seguidas por letras distintas na coluna diferem entre si pelo teste de Tukey ao nível de 5\%

Verifica-se na Tabela 23, quando comparadas as doses de $\mathrm{CO}_{2}$ dentro da produtividade total de tubérculos, não houve diferença significativa. Observando-se apenas tendência de incremento quando aplicou-se a dose 2 (205,2 $\mathrm{kg} \mathrm{ha}^{-1}$ de $\mathrm{CO}_{2}$ ), decrescendo com doses superiores.

Neste experimento, enriquecendo a água de irrigação $c o m \mathrm{CO}_{2}$, não se alcançou incremento no rendimento. Possivelmente, este incremento é conseqüência dos efeitos combinados do enriquecimento de $\mathrm{CO}_{2}$ e as modificações no ambiente do solo em função da disponibilidade de nutrientes, como indica Novero et al. (1991).

\subsubsection{Classificação comercial de batata}

O quadro de análise da variância mostrou que não houve diferença significativa, pelo teste $\mathrm{F}$, entre os níveis de $\mathrm{CO}_{2}$ ao nível de $1 \%$, dentro de cada classe. $O$ detalhamento da análise, pelo teste de Tukey, está apresentado na Tabela 24. 
Tabela 24. Médias originais da classificação comercial e descarte de batata (\%) em função das doses de $\mathrm{CO}_{2}$

\begin{tabular}{cccccc}
\hline Tratamentos & \multicolumn{2}{c}{ Médias de Classificação Comercial de Batata (\%) } & Descarte (\%) \\
\hline Especial & Primeira & Segunda & Miudinha & \\
\hline T1 & $54,41 \mathrm{a}$ & $33,78 \mathrm{a}$ & $7,04 \mathrm{a}$ & $1,26 \mathrm{a}$ & $3,51 \mathrm{a}$ \\
T2 & $53,07 \mathrm{a}$ & $34,33 \mathrm{a}$ & $7,90 \mathrm{a}$ & $0,85 \mathrm{a}$ & $3,85 \mathrm{a}$ \\
T3 & $55,57 \mathrm{a}$ & $30,49 \mathrm{a}$ & $7,26 \mathrm{a}$ & $0,79 \mathrm{a}$ & $5,89 \mathrm{a}$ \\
T4 & $57,88 \mathrm{a}$ & $27,81 \mathrm{a}$ & $6,67 \mathrm{a}$ & $0,86 \mathrm{a}$ & $6,78 \mathrm{a}$ \\
T5 & $55,97 \mathrm{a}$ & $31,88 \mathrm{a}$ & $7,69 \mathrm{a}$ & $0,84 \mathrm{a}$ & $3,62 \mathrm{a}$ \\
\hline
\end{tabular}

Médias seguidas por letras distintas nas colunas diferem entre si pelo teste de Tukey ao nível de $5 \%$

Observa-se na Tabela 24 que não ocorreu nenhuma diferença significativa dentro de cada classe com a variação das dosagens de $\mathrm{CO}_{2}$. Porém, entre classes, evidencia-se que a especial apresentourse em maioria (superior a $50 \%$ ) com relação a produção comercial, independente da dosagem de $\mathrm{CO}_{2}$, registrando maior massa, e conseqüentemente, maior valor econômico, seguida pelas classes primeira, segunda e miudinha respectivamente.

A Figura 26 permite visualizar o comportamento da classificação comercial de batata em função das doses de $\mathrm{CO}_{2}$ aplicadas.

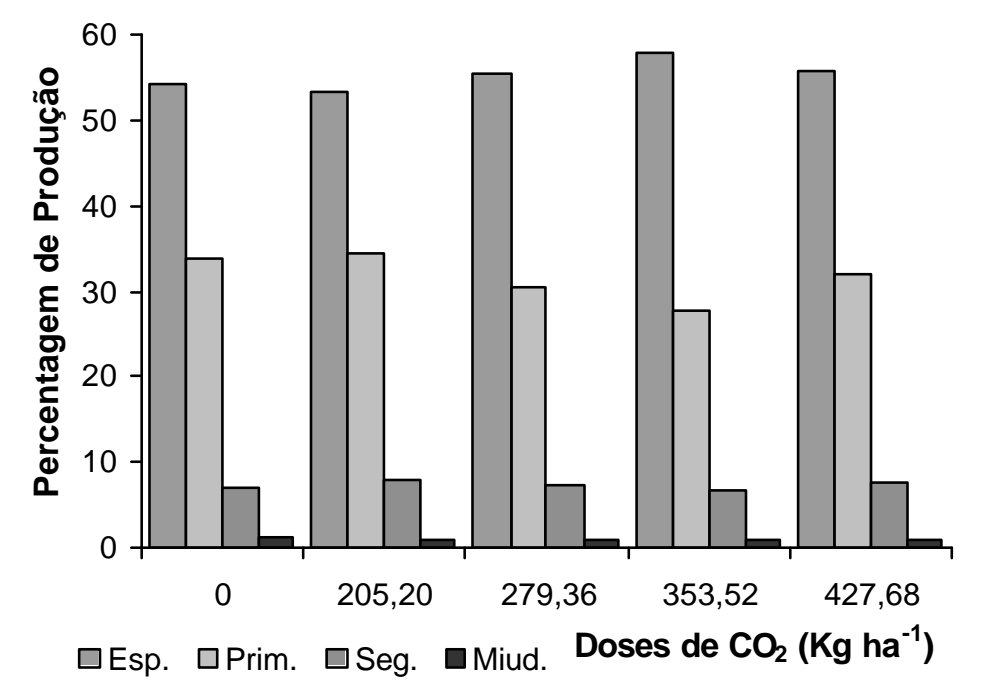

Figura 26 - Classificação comercial de batata (\%) em função da doses de $\mathrm{CO}_{2}$ aplicadas 


\subsubsection{Sólidos solúveis totais dos tubérculos}

O quadro de análise da variância mostrou que houve diferença significativa, pelo teste $\mathrm{F}$, entre os níveis de $\mathrm{CO}_{2}$ ao nível de $1 \%$, para a variável sólidos solúveis dos tubérculos. O detalhamento da análise, pelo teste de Tukey, está apresentado na Tabela 25.

Tabela 25. Médias originais de sólidos solúveis totais para o fator tratamento

\begin{tabular}{cc}
\hline Tratamentos & $\begin{array}{c}\text { Sólidos solúveis totais } \\
\text { (oBrix) }\end{array}$ \\
\hline T1 & $4,61 \mathrm{a}$ \\
T2 & $4,45 \mathrm{ab}$ \\
T3 & $4,29 \mathrm{ab}$ \\
T4 & $4,13 \mathrm{ab}$ \\
T5 & $3,97 \mathrm{~b}$ \\
\hline Médias seguidas por letras distintas na coluna diferem entre si pelo teste de Tukey ao nível de $5 \%$
\end{tabular}

Verifica-se na Tabela 25 que a menor média foi encontrada com a maior dose de $\mathrm{CO}_{2}$ aplicada, ou seja, a 427,68 $\mathrm{kg} \mathrm{ha}^{-1}$. Isto indica que o incremento de $\mathrm{CO}_{2}$ na água de irrigação ocasionou a redução do teor de sólidos solúveis totais. A maior média de teor de sólidos solúveis totais foi encontrada no tratamento sem aplicação de $\mathrm{CO}_{2}$. A tendência de redução, também ocorreu com as doses intermediárias. Ao comparar-se os teores extremos de $\mathrm{CO}_{2}$ utilizados, verificour se que o teor de sólidos solúveis foi 15 a 20 \% menor com a dose de 427,68 kg $\mathrm{ha}^{-1}$.

Possivelmente, o aumento na concentração de $\mathrm{CO}_{2}$ aumenta a função carboxilase da enzima RUBISCO em detrimento a função oxigenase da mesma. Assim, maior quantidade de $\mathrm{CO}_{2}$ é fixada na forma de amido devido à transformação dos açúcares em amido, como relatam Harman \& Watkins (1981) e Peterson et al. (1985).

A Figura 27 permite visualizar a equação de regressão de sólidos solúveis totais de batata em função das doses de $\mathrm{CO}_{2}$ aplicadas. 


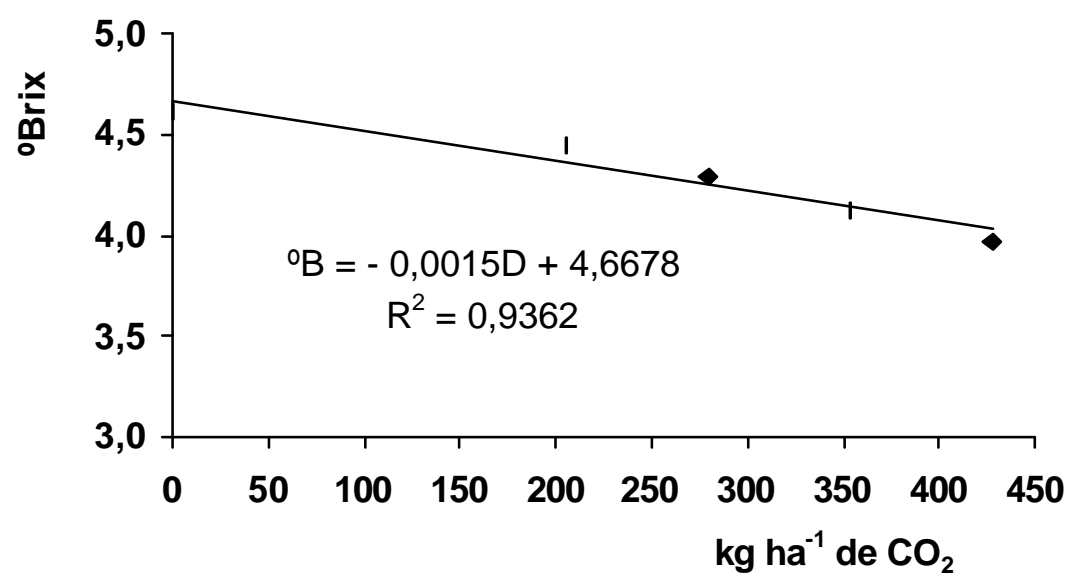

Figura 27 - Curva e equação de regressão para Brix da batata em função das doses: $\quad \mathrm{D} 1=0 ; \quad \mathrm{D} 2=205,2 ; \quad \mathrm{D} 3=279,36 ; \quad \mathrm{D} 4=353,52 ; \quad \mathrm{D} 5=427,68$ $\mathrm{kg} \mathrm{ha}^{-1}$ de $\mathrm{CO}_{2}$

Pode-se inferir que o enriquecimento $\operatorname{com} \mathrm{CO}_{2}$ via água de irrigação possivelmente tem maior influencia no que se refere às características tecnológicas, as quais são discutidas com maiores argumentos no experimento II. 


\subsection{Experimento II}

\subsubsection{Elementos meteorológicos}

As exigências climáticas, peculiares e muito precisas no caso de batateira, serão satisfeitas ou não, dependendo das condições agroecológicas.

Os elementos meteorológicos foram coletados da base de dados da ESALQ (2002), e são apresentados na Tabela 26.

Tabela 26. Elementos meteorológicos observados durante o experimento II. Piracicaba, SP. 2002

\begin{tabular}{|c|c|c|c|c|}
\hline \multirow{2}{*}{ Meses } & \multirow{2}{*}{ UR (\%) } & \multicolumn{2}{|c|}{ Temp. Média Mensal do $\operatorname{Ar}\left({ }^{\circ} \mathrm{C}\right)$} & \multirow{2}{*}{ TMédia $\left({ }^{\circ} \mathrm{C}\right)$} \\
\hline & & Máx. $\left({ }^{\circ} \mathrm{C}\right)$ & Mín. $\left({ }^{\circ} \mathrm{C}\right)$ & \\
\hline Maio & 77,45 & 26,84 & 14,50 & 20,67 \\
\hline Junho & 68,07 & 27,92 & 12,63 & 20,28 \\
\hline Julho & 67,94 & 25,21 & 10,19 & 17,70 \\
\hline Agosto & 62,23 & 28,92 & 14,32 & 21,62 \\
\hline Setembro & 60,53 & 27,52 & 13,63 & 20,58 \\
\hline
\end{tabular}

O fator climático limitante na batata é a temperatura elevada, especialmente a noturna. Quando esta se mantém acima de $20^{\circ} \mathrm{C}$, durante 60 dias, não ocorre a tuberização. A batateira exige uma diferença termoperiodicidade diária - entre as temperaturas diurnas amenas e noturnas mais baixas, em torno de $10^{\circ} \mathrm{C}$, e nenhum fitomelhorista conseguiu modificar essa característica. $O$ fotoperíodo também afeta a planta, entretanto não é fator limitante (Filgueira, 1999).

$\mathrm{Na}$ Figura 28 estão apresentados os dados referentes às condições climáticas durante o experimento II. 


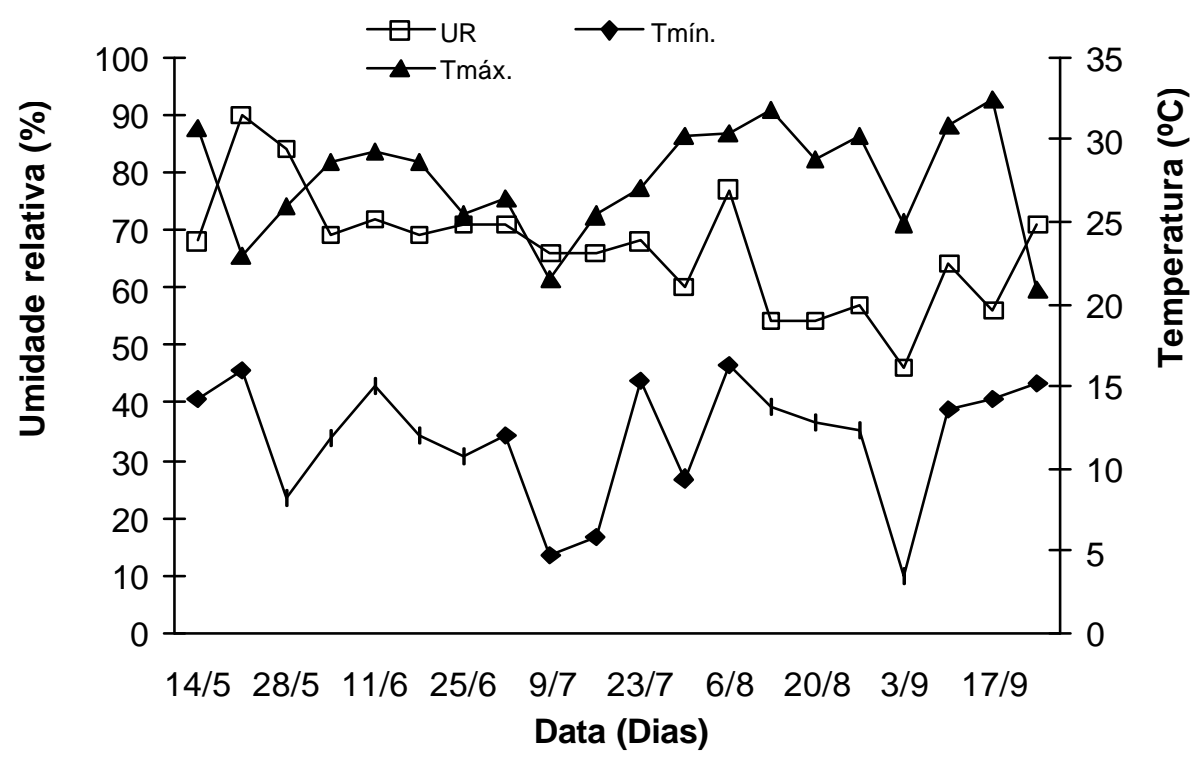

Figura 28 - Valores semanais de umidade relativa, temperatura máxima e temperatura mínima do ar durante o período do experimento II. Piracicaba, SP. 2002

\subsubsection{Uniformidade de irrigação}

$\mathrm{Na}$ irrigação por gotejamento, apesar de ser esse o método de irrigação em que se tem um melhor controle da lâmina aplicada, é recomendável, após a instalação do sistema e a cada dois anos de funcionamento, determinar a uniformidade de irrigação (Bernardo, 1995).

Na Figura 29 apresenta-se a uniformidade com que foi aplicado durante 0 experimento II, sendo a uniformidade estatística de $91,55 \%$ e coeficiente de variação de $8,45 \%$. Karmeli \& Keller (1974) reportaram, que a uniformidade de aplicação de água na irrigação por gotejamento não deve ser inferior a $90 \%$; neste experimento a uniformidade foi superior ao valor indicado, garantindo uma distribuição uniforme dos emissores. 


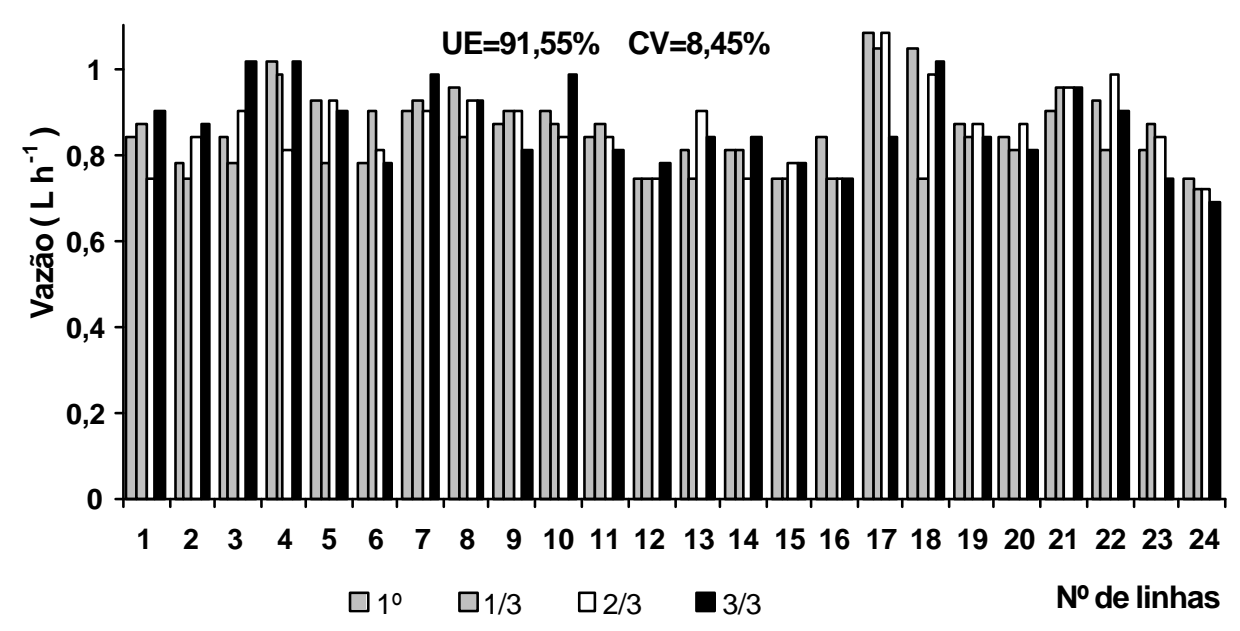

Figura 29 - Uniformidade de distribuição de irrigação do experimento II

\subsubsection{Manejo de irrigação e aplicação de $\mathrm{CO}_{2}$}

\subsubsection{Irrigação}

O manejo da irrigação foi semelhante ao do experimento I. A lâmina de água aplicada à cultura, pela irrigação, durante o ciclo de 117 dias, foi de 175,24 $\mathrm{mm}$. A precipitação registrada nesse período foi de $115,18 \mathrm{~mm}$, resultando num total de água incorporada ao solo de $290,42 \mathrm{~mm}$. A evaporação pelo tanque Classe A para o mesmo período foi de $347,85 \mathrm{~mm}$.

A umidade do solo foi monitorada por meio da leitura do potencial mátrico medido por tensiômetros instalados na área experimental. Na Figura 30 pode-se observar em módulo o potencial mátrico durante o período do experimento. 


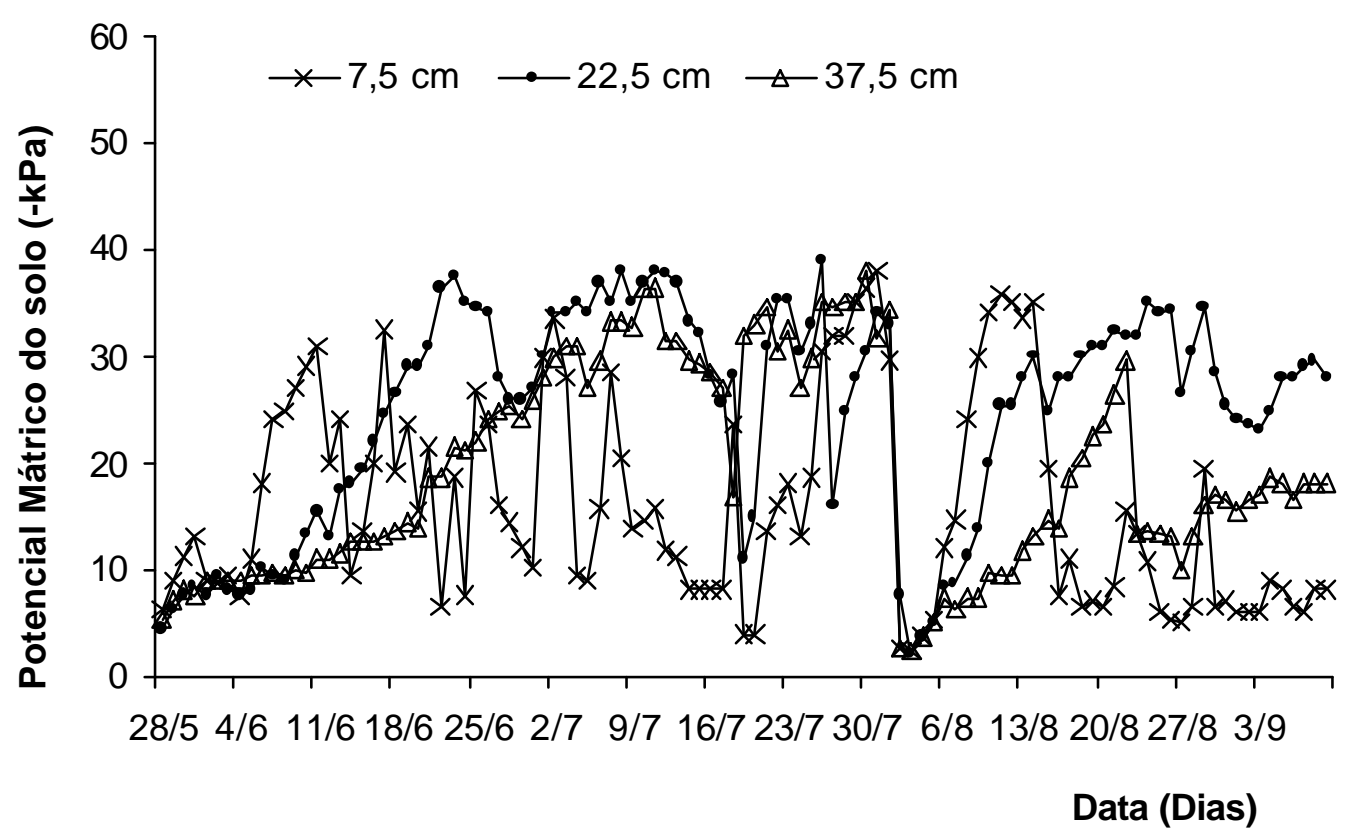

Figura 30 - Leitura dos tensiômetros $(-\mathrm{kPa})$ a três profundidades nas parcelas durante o período do experimento II

Na Figura 31 observa-se que durante o experimento II ocorreram chuvas concentradas principalmente na primeira semana de agosto, chegando próximo a $40 \mathrm{~mm}$, o que obrigou a interrupção da irrigação, e conseqüentemente, da aplicação de $\mathrm{CO}_{2}$. 


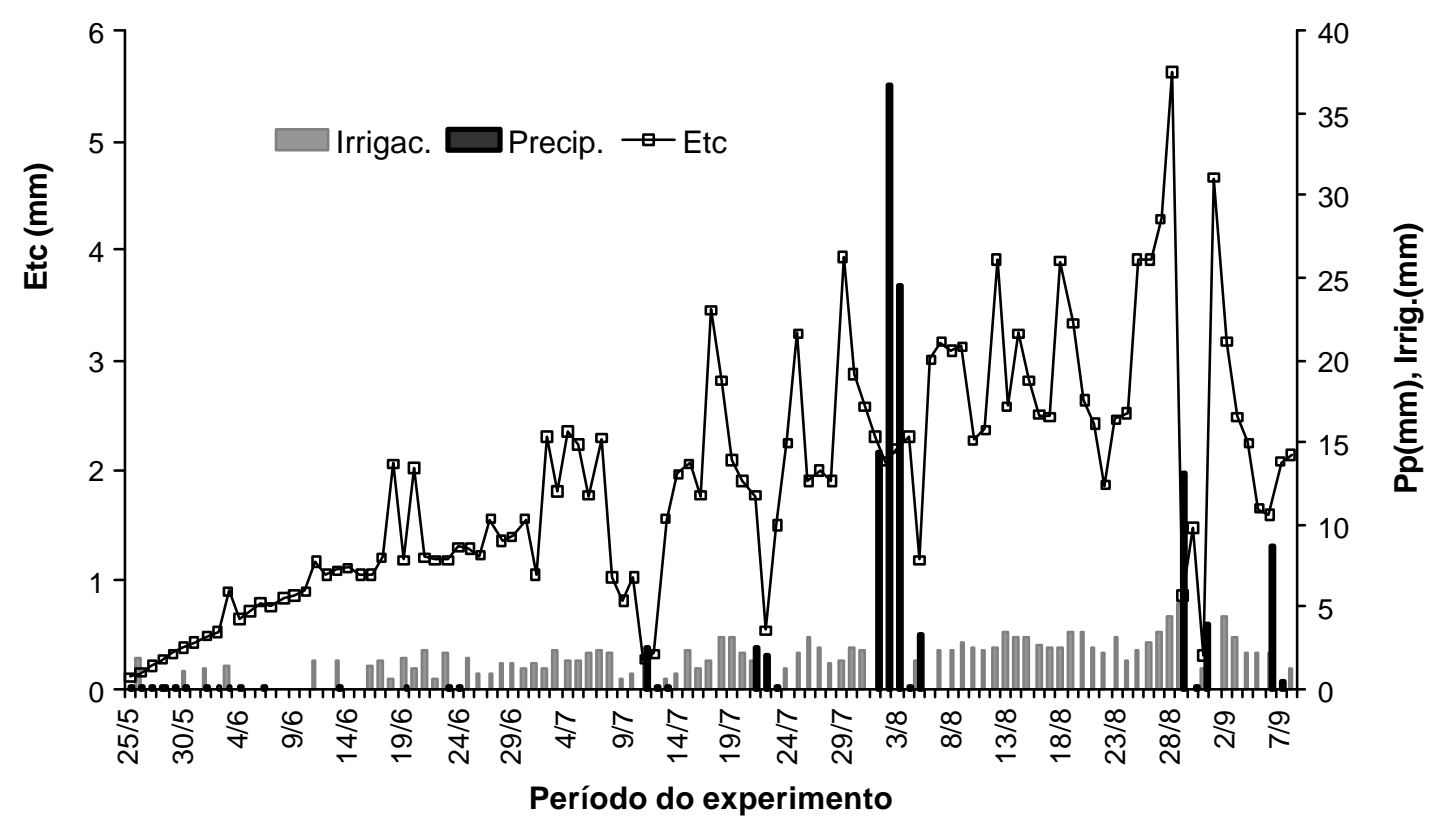

Figura 31 - Quantidade de água aplicada em função da evapotranspiração da cultura (Etc) e precipitação durante o experimento II

\subsubsection{Aplicação de $\mathrm{CO}_{2}$}

$\mathrm{Na}$ Tabela 27 apresentan-se as doses de $\mathrm{CO}_{2}$ por hectare utilizado em cada tratamento durante o ciclo da cultura no experimento II

Tabela 27. Quantidade de $\mathrm{CO}_{2}$ utilizada por hectare em cada tratamento na cultura de batata nos cultivares Atlantic, Jatte-Bintje e Monalisa durante ciclo da cultura no experimento II, 2002

\begin{tabular}{cccc} 
Tratamento & $\begin{array}{c}{\left[\mathrm{CO}_{2}\right]} \\
\mathrm{ppm}\end{array}$ & \multicolumn{2}{c}{$\mathrm{CO}_{2}$ utilizado $\left(\mathrm{kg} \mathrm{ha}^{-1}\right)$} \\
& 0 & 0,0 & Real \\
\hline $\mathrm{T} 1$ & 400 & 145,36 & 0,0 \\
$\mathrm{~T} 2$ & 800 & 290,72 & 130,38 \\
$\mathrm{~T} 3$ & & & 260,57 \\
\hline
\end{tabular}




\subsubsection{Medição de pH no solo}

\subsubsection{Cultivar Atlantic}

A análise de variância mostrou que houve diferença significativa, pelo teste $\mathrm{F}$, entre o tempo de leitura de $\mathrm{pH}$ (antes, durante e após de aplicação de $\mathrm{CO}_{2}$ ), não ocorrendo entre a doses de $\mathrm{CO}_{2}$, nem para a interação. $\mathrm{O}$ detalhamento da análise, pelo teste de Tukey, está apresentada na Tabela 28.

Tabela 28. Médias originais de pH do solo antes, durante e após da aplicação de $\mathrm{CO}_{2}$ no cultivar Atlantic

\begin{tabular}{cc}
\hline Modalidade de leitura & pH do solo \\
\hline Antes da aplicação de $\mathrm{CO}_{2}$ & $5,68 \mathrm{a}$ \\
Durante a aplicação de $\mathrm{CO}_{2}$ & $4,83 \mathrm{~b}$ \\
Depois da aplicação de $\mathrm{CO}_{2}$ & $5,02 \mathrm{~b}$ \\
\hline
\end{tabular}

Médias seguidas por letras minúsculas iguais nas colunas não diferem entre si pelo teste de Tukey ao nível de $5 \%$

Verifica-se que a maior média de $\mathrm{pH}(5,68)$ foi observada quando foi realizada a leitura antes da aplicação de $\mathrm{CO}_{2}$. Entretanto, durante a aplicação de $\mathrm{CO}_{2} \mathrm{o}$ valor de $\mathrm{pH}$ caiu para 4,83, diferenciando-se significativamente da primeira leitura. Depois de paralisada a aplicação de $\mathrm{CO}_{2}, \mathrm{opH}$ tendeu a recuperar seu valor inicial, chegando a 5,02. Hartz \& Holt (1991) observaram uma diminuição de $\mathrm{pH}$ de 7,3 para 5,3 , mas a mudança de $\mathrm{pH}$ foi transitório, concordando com o que aconteceu neste experimento.

$\mathrm{Na}$ Figura 32 pode-se visualizar a variação de $\mathrm{pH}$ antes, durante e após da aplicação de $\mathrm{CO}_{2}$. Observa-se que com o tratamento $\mathrm{T} 1$ (sem aplicação de $\mathrm{CO}_{2}$ ) os valores de $\mathrm{pH}$ foram sempre maiores do que quando foram aplicados os tratamentos T2 e T3; embora mesmo com T1, os valores diminuíram durante a aplicação, possivelmente, devido a que a água misturou-se com a solução do solo. Assim também, tanto em T2 e T3, as leituras de pH antes da aplicação de $\mathrm{CO}_{2}$ apresentaram-se superiores para em seguida diminuir e logo tender a recuperar seu valor original. 


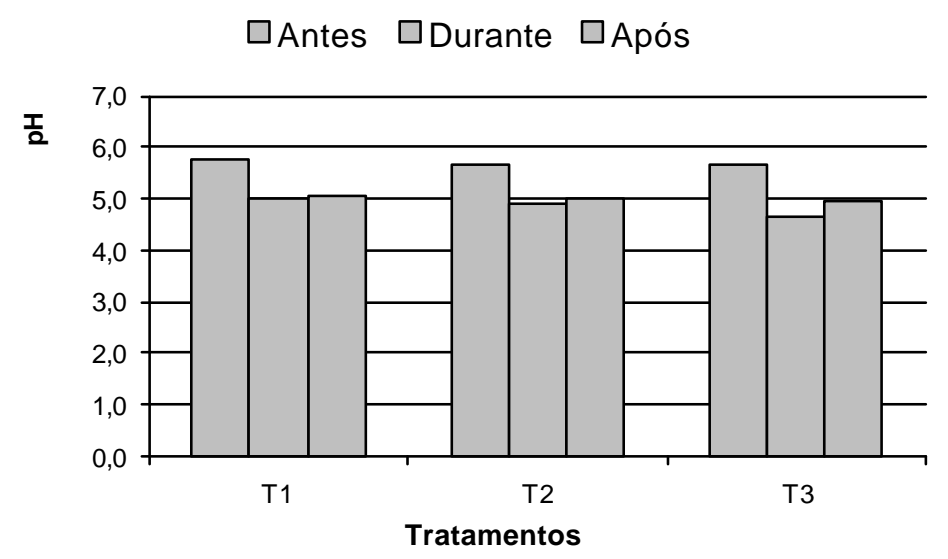

Figura 32 - pH do solo antes, durante e após da aplicação dos tratamentos de $\mathrm{CO}_{2}$ (T1 - 0; T2- 145,36; T3- 290,72 $\mathrm{kg} \mathrm{ha}^{-1}$ ) no cultivar Atlantic

\subsubsection{Cultivar Jatte-Bintje}

A análise de variância mostrou que houve diferença significativa, pelo teste F entre o tempo de leitura de pH (antes, durante e após da aplicação de $\mathrm{CO}_{2}$ ), e entre a doses de $\mathrm{CO}_{2}$ ao nível de $5 \%$. Entretanto não apresentou diferença significativa para a interação. Os detalhamentos da análise, pelo teste de Tukey, estão apresentados nas Tabelas 29 e 30.

Tabela 29. Médias originais de pH do solo antes, durante e após da aplicação de $\mathrm{CO}_{2}$ no cultivar Jatte-Bintje

Modalidade de leitura

Antes da aplicação de $\mathrm{CO}_{2}$ $\mathrm{pH}$ do solo

\begin{tabular}{cc} 
Modalidade de leitura & $\mathrm{pH}$ do solo \\
\hline Antes da aplicação de $\mathrm{CO}_{2}$ & $5,78 \mathrm{a}$ \\
Durante a aplicação de $\mathrm{CO}_{2}$ & $4,72 \mathrm{c}$ \\
Depois da aplicação de $\mathrm{CO}_{2}$ & $4,97 \mathrm{~b}$ \\
\hline
\end{tabular}

Médias seguidas por letras minúsculas iguais nas colunas não diferem entre si pelo teste de Tukey ao nível de $5 \%$

Verifica-se na Tabela 29, quando comparados os eventos de leitura de $\mathrm{pH}$, a maior média $(5,78)$ foi encontrada antes da aplicação de $\mathrm{CO}_{2}$, e a menor média $(4,72)$ quando a leitura foi realizada durante a aplicação de $\mathrm{CO}_{2}$. Quando foi lido o pH após corte da aplicação de $\mathrm{CO}_{2}$, o valor de $\mathrm{pH}$ voltou incrementar-se 
até 4,97. Tognoni et al. (1967) elevando a concentração de $\mathrm{CO}_{2}$ no solo, observou uma diminuição de $\mathrm{pH}$ do solo e como conseqüência ocorreu incremento na absorção de nutrientes, fato este que não aconteceu no presente experimento.

$\mathrm{Na}$ Tabela 30, comparando-se os tratamentos em cada uma das modalidades de leitura de $\mathrm{pH}$, observa-se que nos três eventos (antes, durante, e após) a maior média foi obtida com o tratamento T1 (sem aplicação de $\mathrm{CO}_{2}$ ), e a menor média com os tratamentos T2 e T3, que não foram diferentes significativamente entre si, igual nas três modalidades.

Tabela 30. Médias originais de $\mathrm{pH}$ do solo antes, durante e após da aplicação dos tratamentos (T1- 0; T2- 145,36; T3- 290,72 $\mathrm{kg} \mathrm{ha}^{-1}$ de $\mathrm{CO}_{2}$ ) no cultivar Jatte-Bintje

\begin{tabular}{cccc}
\hline Tratamento & Antes & Durante & Depois \\
\hline T1 & $6,00 \mathrm{a}$ & $5,00 \mathrm{a}$ & $5,20 \mathrm{a}$ \\
T2 & $5,62 \mathrm{~b}$ & $4,60 \mathrm{~b}$ & $4,85 \mathrm{~b}$ \\
T3 & $5,72 \mathrm{~b}$ & $4,55 \mathrm{~b}$ & $4,87 \mathrm{~b}$ \\
\hline Médias seguidas por letras minúsculas iguais nas colunas não diferem entre si pelo teste de Tukey ao
\end{tabular}
nível de $5 \%$

A Figura 33 permite visualizar a variação de $\mathrm{pH}$ dentro dos tratamentos e dentro das modalidades de leitura. A tendência é apresentar $\mathrm{pH}$ alto ao inicio, logo durante a aplicação de $\mathrm{CO}_{2}$ cair o valor de $\mathrm{pH}$, para após tender a voltar ao valor inicial, quando é concluída a aplicação de $\mathrm{CO}_{2}$. 


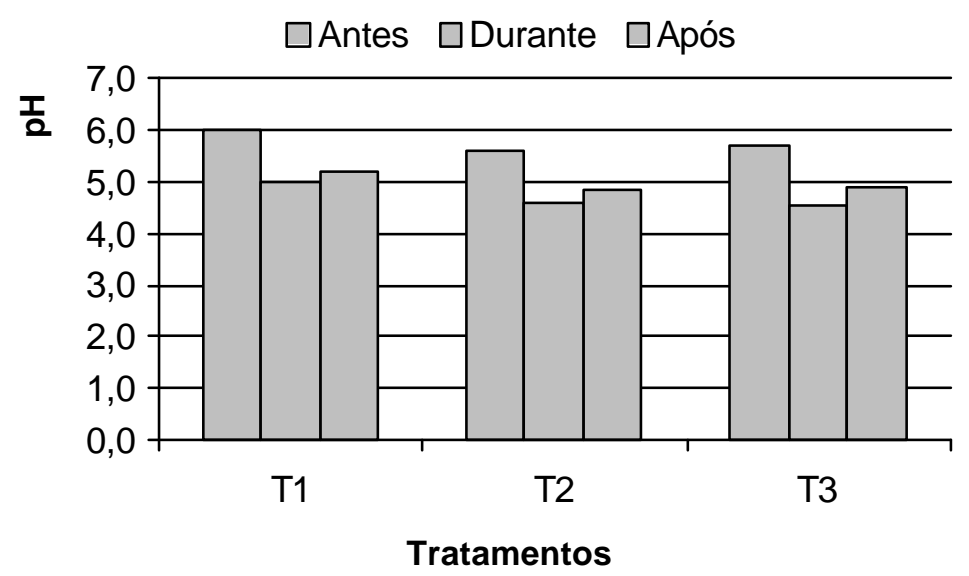

Figura 33 - pH do solo antes, durante e após da aplicação dos tratamentos (T1- 0; T2- 145,36; T3- 290,72 $\mathrm{kg} \mathrm{ha}^{-1}$ de $\mathrm{CO}_{2}$ ) no cultivar JatteBintje

\subsubsection{Cultivar Monalisa}

A análise de variância mostrou que houve diferença significativa, pelo teste $\mathrm{F}$, entre o tempo de leitura de $\mathrm{pH}$ (antes, durante e após da aplicação de $\mathrm{CO}_{2}$ ) ao nível de $5 \%$. Entretanto não houve diferença significativa entre a doses de $\mathrm{CO}_{2}$, nem para a interação ao nível de 5\%. O detalhamento da análise, pelo teste de Tukey, está apresentado na Tabela 31.

Tabela 31. Médias originais de pH do solo antes, durante e após da aplicação de $\mathrm{CO}_{2}$ no cultivar Monalisa

\begin{tabular}{cc}
\hline Modalidade de leitura & pH do solo \\
\hline Antes da aplicação de $\mathrm{CO}_{2}$ & $5,65 \mathrm{a}$ \\
Durante a aplicação de $\mathrm{CO}_{2}$ & $4,58 \mathrm{c}$ \\
Depois da aplicação de $\mathrm{CO}_{2}$ & $4,94 \mathrm{~b}$ \\
\hline
\end{tabular}

Médias seguidas por letras minúsculas iguais nas colunas não diferem entre si pelo teste de Tukey ao nível de $5 \%$

Verifica-se, quando comparados os valores de $\mathrm{pH}$ dentro das modalidades de leitura, que a maior média $(5,65)$ foi observada quando foi 
realizada a leitura antes da aplicação de $\mathrm{CO}_{2}$, e a menor média $(4,58)$ apresentou-se quando a leitura foi realizada durante a aplicação de $\mathrm{CO}_{2}$.

A Figura 34 permite visualizar as variações dos valores de $\mathrm{pH}$ dentro dos tratamentos e entre as modalidades de leitura.

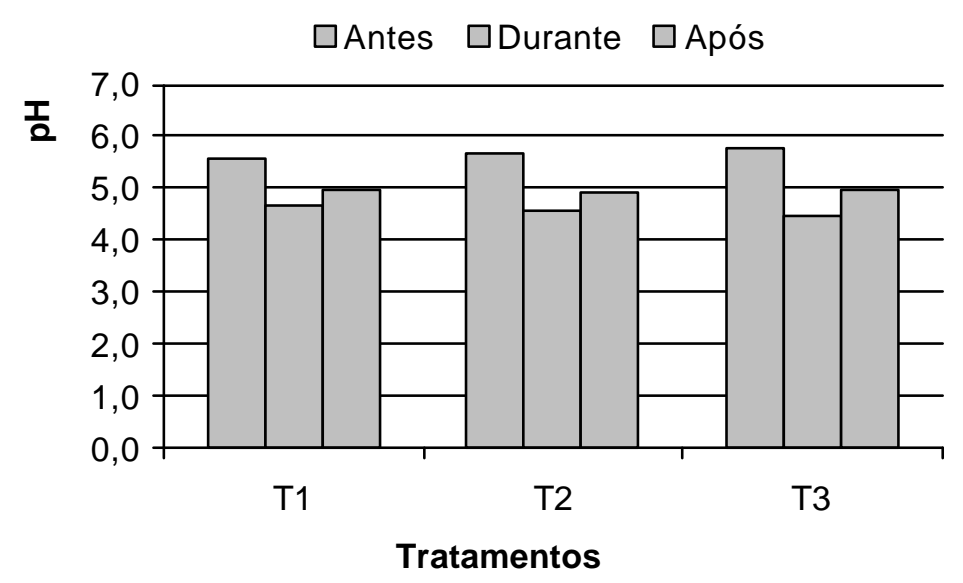

Figura 34 - pH do solo antes, durante e após da aplicação dos tratamentos (T1- 0; T2- 145,36; T3- 290,72 $\mathrm{kg} \mathrm{ha}^{-1}$ de $\mathrm{CO}_{2}$ ) no cultivar Monalisa

\subsubsection{Acúmulo de nutrientes na parte aérea, raízes e tubérculos}

Na Figura 35 apresenta-se o acúmulo de macronutrientes: N, P, K, Ca, Mg e S na parte aérea, raízes e tubérculos dos cultivares Atlantic, Jatte-Bintje e Monalisa.

Dos três cultivares, o acúmulo máximo de Nitrogênio $(\mathrm{N})$ ocorreu no cv. Jatte-Bintje, apresentando um total de 3.055,45 mg planta ${ }^{-1}\left(95,48 \mathrm{~kg} \mathrm{ha}^{-1}\right)$ para uma produção de 20,97 $\mathrm{t} \mathrm{ha}^{-1}$ quando se aplicou a dose 1 (sem aplicação de $\mathrm{CO}_{2}$ ), seguido pelo cv Atlantic 2.796,65 mg planta ${ }^{-1}\left(87,40 \mathrm{~kg} \mathrm{ha}^{-1}\right)$, e Monalisa 2.245,90 $\mathrm{mg}$ planta $^{-1}\left(70,18 \mathrm{~kg} \mathrm{ha}^{-1}\right)$. Yorinori (2003) reportou o acúmulo máximo de $3.362,14 \mathrm{mg} \mathrm{planta}^{-1}$ de $\mathrm{N}\left(140 \mathrm{~kg} \mathrm{ha}^{-1}\right)$ para uma produtividade de $36,5 \mathrm{t} \mathrm{ha}^{-1}$ 
na safra das águas e 2.860,71 mg planta ${ }^{-1}$ de $\mathrm{N}$ (119 $\mathrm{kg} \mathrm{ha}^{-1}$ ) para uma produtividade de $24 \mathrm{t} \mathrm{ha}^{-1}$ na safra da seca no cv. Atlantic.
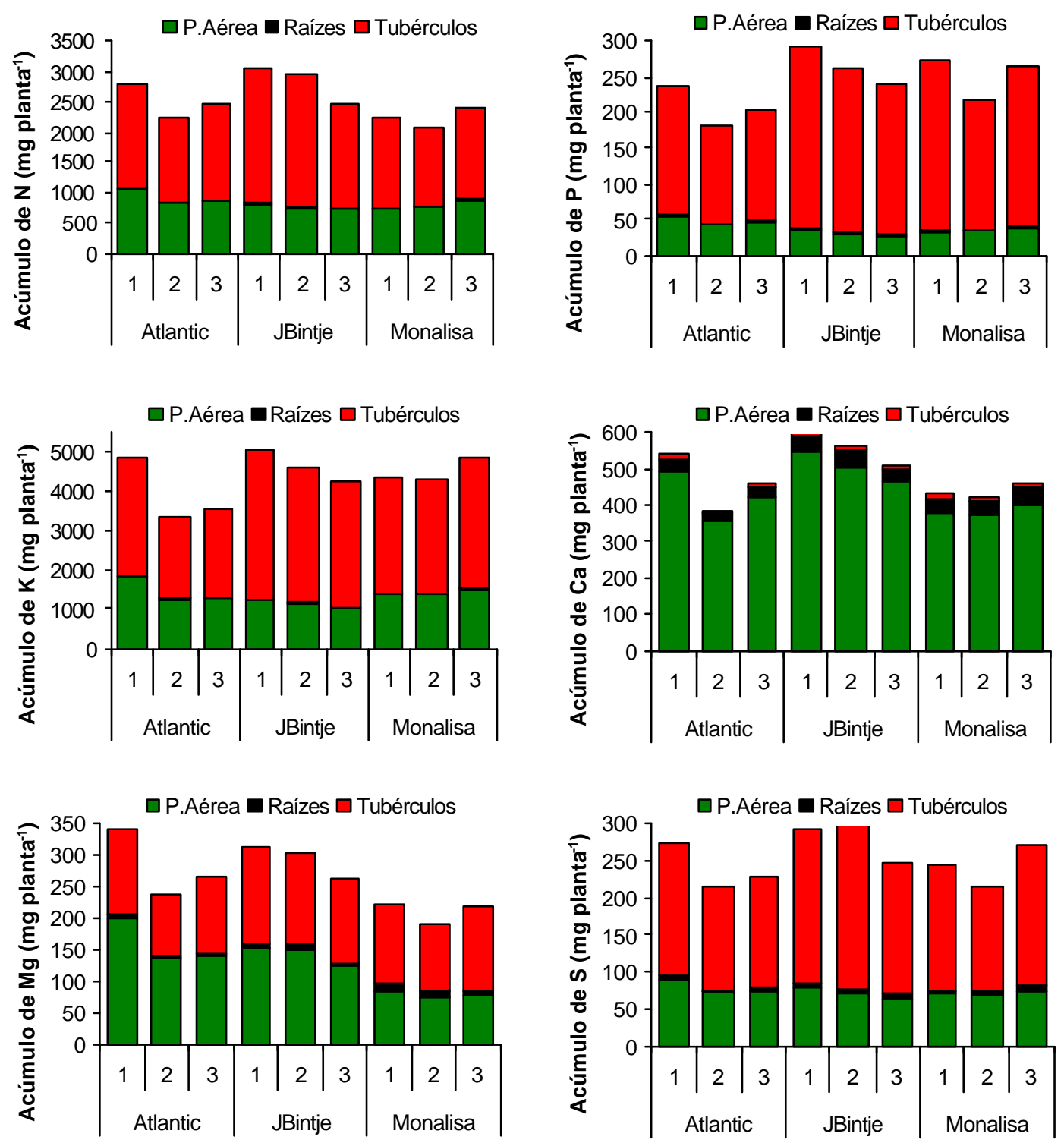

Figura 35 - Nitrogênio, Fósforo, Potássio, Cálcio, Magnésio, e Enxofre acumulados nos órgãos da batata aos 114 DAP (mg planta $\left.{ }^{-1}\right)$ em função das doses 1=0; $2=145,36 ; 3=290,72 \mathrm{~kg} \mathrm{ha}^{-1}$ de $\mathrm{CO}_{2}$ 
$\mathrm{O}$ acúmulo de $\mathrm{N}$ na parte aérea e nos tubérculos aos 114 DAP foi de $1.068,12$ e 1.711,15 mg planta $^{-1}$ para o cv. Atlantic, 833,04 e 2.198,61 $\mathrm{mg}_{\text {planta }}{ }^{-1}$ para o cv. Jatte-Bintje e 746,70 e $1.481,87 \mathrm{mg}$ planta ${ }^{-1}$ para o cv. Monalisa. Para Yorinori (2003), o acúmulo máximo de $\mathrm{N}$ nas raízes, caules, folhas e tubérculos aos 111 DAP foi de 2.933,54 $\mathrm{mg}$ planta $^{-1}$ na safra das águas e 2.736,24 mg planta $^{-1}$, aos $90 \mathrm{DAP}$, na safra da seca para o cv Atlantic.

$O$ acúmulo máximo de fósforo $(P)$ ocorreu com a dose 1 nos três cultivares, no entanto, o cv. Jatte-Bintje reportou o maior acúmulo $(291,30 \mathrm{mg}$ planta $^{-1}$ ) seguido do cv. Monalisa (274,06 mg planta $\left.^{-1}\right)$ e 'Atlantic' $(2.34,57 \mathrm{mg}$ planta $^{-1}$ ). Yorinori (2003) encontrou o acúmulo máximo de $\mathrm{P}$ total de $422,91 \mathrm{mg}$ planta $^{-1}$, para 36,5 $\mathrm{t} \mathrm{ha}^{-1}$ na safra das águas e 366,33 $\mathrm{mg} \mathrm{planta}^{-1}$ para $24 \mathrm{t} \mathrm{ha}^{-1}$ na safra da seca, no cv. Atlantic.

O acúmulo máximo de $P$ na parte aérea e nos tubérculos foi de 23,09 e $76,28 \%$ no cv. Atlantic, 11,79 e $87,57 \%$ no cv. Jatte-Bintje e 12,19 e $87,34 \%$ no cv. Monalisa, respectivamente, quando se aplicou a dose 1.

O acúmulo máximo de potássio $(\mathrm{K})$ aos 114 DAP ocorreu quando se aplicou a dose 1 nos cv Atlantic (4871,85 mg planta ${ }^{-1}$ ) e Jatte-Bintje $(5047,74 \mathrm{mg}$ planta $\left.^{-1}\right)$; já no cv. Monalisa o acúmulo máximo ocorreu quando se aplicou a dose $3\left(290,72 \mathrm{~kg} \mathrm{ha}^{-1}\right.$ de $\left.\mathrm{CO}_{2}\right)$. Yorinori (2003), com o cv. Atlantic, observou um acúmulo máximo total de $3.210,5 \mathrm{mg}$ planta $^{-1}$ na safra das águas, e 3.339,4 mg planta $^{-1}$ na safra da seca. $\mathrm{O}$ acúmulo máximo de $\mathrm{K}$ na parte aérea e nos tubérculos foi de 37,92 e $61,98 \%$ no cv. Atlantic, 24,58 e $75,32 \%$ no cv. JatteBintje, respectivamente, quando $₫$ aplicou a dose 1 , e 31,20 e $68,41 \%$ no cv. Monalisa, com a dose 3.

O acúmulo máximo de cálcio (Ca) aos 114 DAP ocorreu quando se aplicou a dose 1 nos cv Atlantic (539,85 mg planta $\left.{ }^{-1}\right)$ e Jatte-Bintje (599,38 mg planta $\left.^{-1}\right)$; já no cv. Monalisa o acúmulo máximo ocorreu com a dose $3(290,72 \mathrm{~kg}$ ha-1 ${ }^{-1}$. O maior responsável pelo acúmulo de Ca nas três cultivares foi a parte aérea, sendo ínfimo nas raízes e nos tubérculos. Yorinori (2003) observou valores 


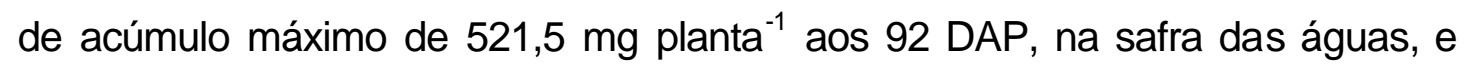
350,2 mg planta $^{-1}$ aos 55 DAP, na safra da seca.

O acúmulo máximo de magnésio $(\mathrm{Mg})$ aos 114 DAP ocorreu com a dose 1 nos cultivares Atlantic (341,60 mg planta $\left.{ }^{-1}\right)$, Jatte-Bintje (314,90 mg planta $\left.^{-1}\right)$, e Monalisa $\left(221,87 \mathrm{mg}\right.$ planta $\left.^{-1}\right)$. Yorinori (2003) mostrou que na safra das águas, 0 acúmulo máximo de $\mathrm{Mg}$ total foi de $344 \mathrm{mg}$ planta $^{-1} \quad(14,3$ $\left.\mathrm{kg} \mathrm{ha}^{-1}\right)$ aos 111 DAP, e na safra da seca de 166,4 $\mathrm{mg} \mathrm{planta}^{-1}\left(6,9 \mathrm{~kg} \mathrm{ha}^{-1}\right)$ aos 69 DAP.

O acúmulo máximo de $\mathrm{Mg}$ na parte aérea e nos tubérculos foi de 58,91 e $39,29 \%$ no cv. Atlantic, 48,41 e 50,15\% no cv. Jatte-Bintje, e 38,97 e 56,51\% no cv. Monalisa, respectivamente, quando se aplicou a dose 1.

O acúmulo máximo de enxofre (S) aos 114 DAP com a dose 1 nos cultivares Atlantic, Jatte-Bintje, e Monalisa foram 274,86; 291,53; e 245,33 mg planta ${ }^{-1}$, respectivamente. Entretanto no cv. Jatte-Bintje o acúmulo máximo de $\mathrm{S}\left(296,85 \mathrm{mg}\right.$ planta $\left.^{-1}\right)$ obteve-se com a dose $2 \mathrm{de} \mathrm{CO}_{2}\left(145,36 \mathrm{~kg} \mathrm{ha}^{-1}\right)$, e no cv. Monalisa o acúmulo máximo de $\mathrm{S}\left(272,53 \mathrm{mg} \mathrm{planta}^{-1}\right)$ ocorreu com a dose 3 de $\mathrm{CO}_{2}\left(290,72 \mathrm{~kg} \mathrm{ha}^{-1}\right)$. Yorinori (2003), indicou que o acúmulo máximo de $\mathrm{S}$ total foi de 260,6 $\mathrm{mg} \mathrm{planta}^{-1}\left(10,8 \mathrm{~kg} \mathrm{ha}^{-1}\right)$ aos $111 \mathrm{DAP}$, na safra das águas, e de 161,4 mg planta $^{-1}\left(6,7 \mathrm{~kg} \mathrm{ha}^{-1}\right)$ aos 87 DAP, na safra da seca.

O acúmulo máximo de $S$ na parte aérea e nos tubérculos foi de 32,85 e $65,10 \%$ no cv. Atlantic, 27,25 e 70,83\% no cv. Jatte-Bintje, e 28,03 e 69,69\% no cv. Monalisa, respectivamente, quando se aplicou a dose 1.

Na Figura 36 apresenta-se o acúmulo de micronutrientes B, Cu, Fe, Mn, e Zn na parte aérea, raízes e tubérculos dos cultivares Atlantic, Jatte-Bintje, e Monalisa.

O acúmulo máximo de boro (B) aos 114 DAP com a dose 1 nos três cultivares foi de 2.959,32; 2.477,24; e 2.405,14 $\mathrm{mg} \mathrm{planta}^{-1}$, respectivamente. Entretanto no cv. Jatte-Bintje o acúmulo máximo de B $\left(2.649,53 \mathrm{mg}_{\text {planta }}{ }^{-1}\right)$ foi 

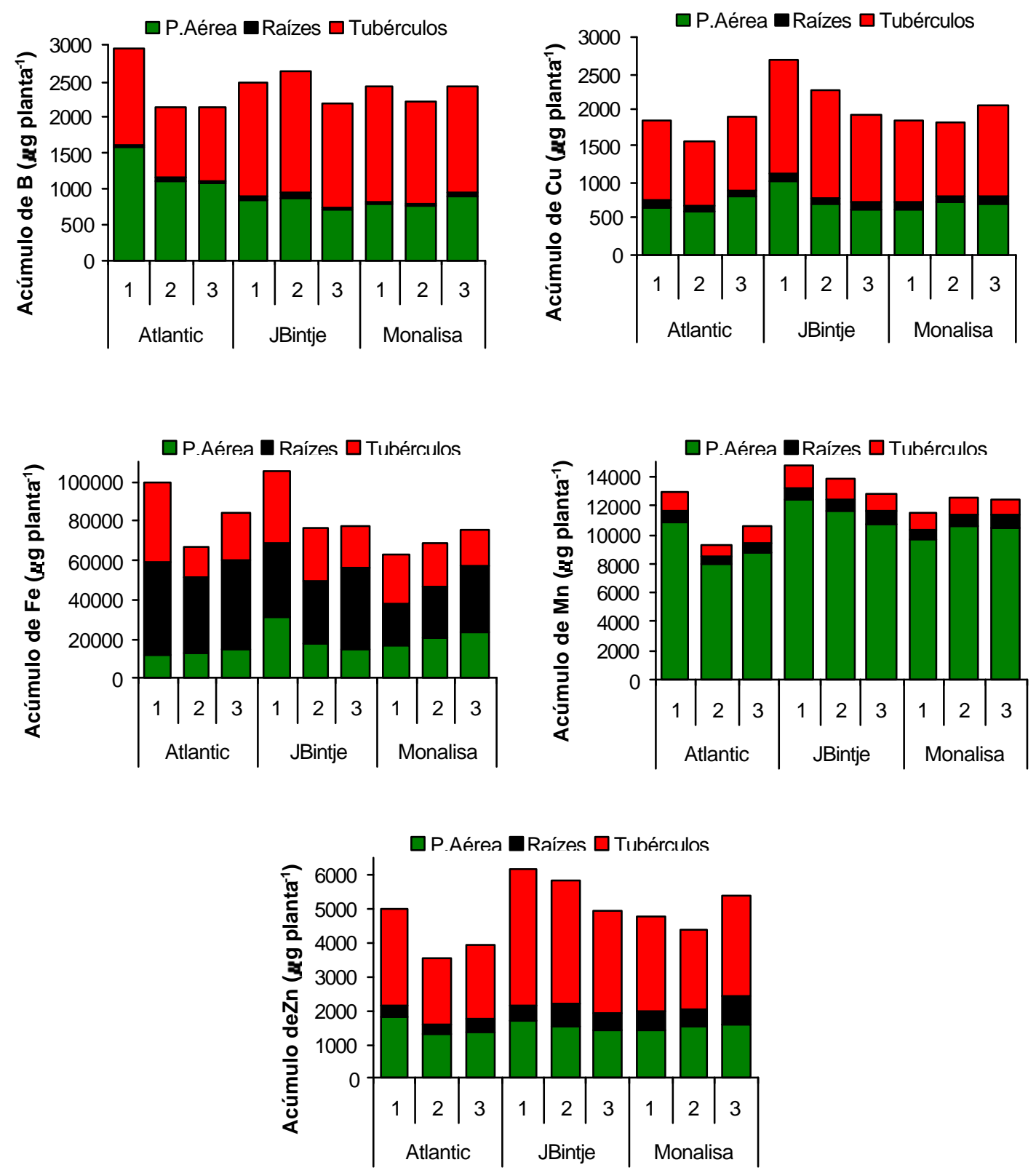

Figura 36 - Boro, Cobre, Ferro, Manganês, e Zinco acumulados nos órgãos da batata aos 114 DAP ( $\mu$ planta $^{-1}$ ) em função das doses $1=0$; $2=145,36 ; 3=290,72 \mathrm{~kg} \mathrm{ha}^{-1}$ de $\mathrm{CO}_{2}$

obtido com a dose 2 de $\mathrm{CO}_{2}\left(145,36 \mathrm{~kg} \mathrm{ha}^{-1}\right)$ e no cv. Monalisa o acúmulo máximo de $\mathrm{B}\left(2.414,83 \mathrm{mg}^{\text {planta }}{ }^{-1}\right)$ foi observado com a dose 3 de $\mathrm{CO}_{2}(290,72$ 
$\left.\mathrm{kg} \mathrm{ha}^{-1}\right)$. Segundo Yorinori (2003), na safra das águas, o acúmulo máximo de B total foi de 2.574,82 $\mu \mathrm{g}_{\text {planta }}{ }^{-1}\left(107,28 \mathrm{~g} \mathrm{ha}^{-1}\right)$ aos $111 \mathrm{DAP}$, e na seca de 2.023,69 $\mu$ g planta $^{-1}\left(84,32 \mathrm{~g} \mathrm{ha}^{-1}\right)$ aos 71 DAP.

O acúmulo máximo de $B$ na parte aérea e nos tubérculos foi de 53,18 e $45,35 \%$ no cv. Atlantic, 34,67 e $63,74 \%$ no cv. Jatte -Bintje, e 31,86 e $66,35 \%$ no cv. Monalisa, respectivamente, quando se aplicou a dose 1.

O acúmulo máximo de cobre $(\mathrm{Cu})$ aos 114 DAP com a dose 1 nos três cultivares foi de 1.859,33; 2.689,63; e 1.855,58 $\mathrm{mg}_{\text {planta }}{ }^{-1}$, respectivamente. Entretanto nos cultivares Atlantic e Monalisa o acúmulo máximo de $\mathrm{Cu}$ foi de $1.907,50$ e $2.060,45 \mathrm{mg}$ planta $^{-1}$, respectivamente, com a dose 3 de $\mathrm{CO}_{2}$ $\left(290,72 \mathrm{~kg} \mathrm{ha}^{-1}\right)$. Já no cv. Jatte-Bintje o acúmulo máximo de Cu foi obtido com a dose 1 de $\mathrm{CO}_{2}$ (sem aplicação de $\mathrm{CO}_{2}$ ). Yorinori (2003), encontrou o acúmulo máximo de Cu total de 1.043,56 $\mu \mathrm{g}_{\text {planta }}{ }^{-1}\left(43,5 \mathrm{~g} \mathrm{ha}^{-1}\right)$ aos $111 \mathrm{DAP}$, e na safra da seca foi de $934,84 \mu \mathrm{g} \mathrm{planta}^{-1}\left(38,9 \mathrm{~g} \mathrm{ha}^{-1}\right)$ aos 90 DAP.

O acúmulo máximo de Cu na parte aérea e nos tubérculos foi de 34,69 e $60,15 \%$ no cv. Atlantic, 37,52 e 58,71\% no cv. Jatte-Bintje, e 32,83 e $61,43 \%$ no cv. Monalisa, respectivamente, quando se aplicou a dose 1.

O acúmulo máximo de ferro $(\mathrm{Fe})$ aos 114 DAP com a dose 1 nos três cultivares foi de 100.108,40; 105.465,50; e 63.731,68 $\mu \mathrm{g}$ planta $^{-1}$, respectivamente. Entretanto no cv. Monalisa o acúmulo máximo de $\mathrm{Fe}$ foi $75.719,45 \mathrm{mg}_{\text {planta }}{ }^{-1}$, com a dose 3 de $\mathrm{CO}_{2}\left(290,72 \mathrm{~kg} \mathrm{ha}^{-1}\right)$. Yorinori (2003), encontrou 0 acúmulo máximo total de $\mathrm{Fe}$ de 29.502,53 $\mu \mathrm{g}$ planta $^{-1}$ $\left(1.229 \mathrm{~g} \mathrm{ha}^{-1}\right)$ aos 111 DAP, na safra das águas, e 18.969,7 $\mu$ planta $^{-1}$ $\left(790 \mathrm{~g} \mathrm{ha}^{-1}\right)$ na safra da seca aos 92 DAP.

O acúmulo máximo de Fe na parte aérea e nos tubérculos foi de 12,23 e $41,37 \%$ no cv. Atlantic, 29,03 e 35,01\% no cv. Jatte-Bintje, e 25,87 e 40,60\% no cv. Monalisa, respectivamente, quando se aplicou a dose 1.

O acúmulo máximo de manganês $(\mathrm{Mn})$ aos 114 DAP com a dose 1 nos três cultivares foi de $12.928,77 ; 14.736,41 ;$ e $11.424,74$ mg planta ${ }^{-1}$, 
respectivamente. Entretanto no cv. Monalisa o acúmulo máximo de $\mathrm{Mn}$ foi 12.582,32 $\mu$ g planta ${ }^{-1}$, com a dose 2 de $\mathrm{CO}_{2}\left(145,36 \mathrm{~kg} \mathrm{ha}^{-1}\right)$. O acúmulo máximo total de Mn encontrado por Yorinori (2003) na safra das águas foi de 5.984,75 $\mu \mathrm{g}$ planta $^{-1}\left(250 \mathrm{~g} \mathrm{ha}^{-1}\right)$ aos 84 DAP, e 3.131,91 $\mu \mathrm{g}$ planta $^{-1} \quad(130$ $\mathrm{g} \mathrm{ha}^{-1}$ ) na safra da seca aos 57 DAP.

O acúmulo máximo de $\mathrm{Mn}$ na parte aérea e nos tubérculos foi de 83,61 e $10,38 \%$ no cv. Atlantic, 84,94 e 9,89\% no cv. Jatte-Bintje, e 85,14 e 9,98\% no cv. Monalisa, respectivamente, quando se aplicou a dose 1 . Pode-se observar que similar ao $\mathrm{Ca}$ a maior parte do Mn encontra-se acumulado na parte aérea.

O acúmulo máximo de zinco ( $\mathrm{Zn}$ ) aos 114 DAP com a dose 1 nos três cultivares foi de 4.983,45; 6.175,06; e 4.741,47 $\mu$ planta $^{-1}$, respectivamente. Entretanto no cv. Monalisa o acúmulo máximo de Zn foi $5.347,19 \mu$ planta $^{-1}$, com a dose 3 de $\mathrm{CO}_{2}\left(290,72 \mathrm{~kg} \mathrm{ha}^{-1}\right)$. Yorinori (2003) mostrou que o acúmulo máximo de $\mathrm{Zn}$ total na safra das águas foi de $3.762,89 \mu \mathrm{g}$ planta $^{-1}$ $\left(156,8 \mathrm{~g} \mathrm{ha}^{-1}\right)$ aos 111 DAP e na safra das seca foi de $2.991,44 \mu \mathrm{g} \mathrm{planta}^{-1}(124,6$ $\mathrm{g} \mathrm{ha}^{-1}$ ) aos 90 DAP.

O acúmulo máximo de Zn na parte aérea e nos tubérculos foi de 35,72 e $56,10 \%$ no cv. Atlantic, 26,77 e $64,91 \%$ no cv. Jatte-Bintje, e 29,42 e $57,70 \%$ no cv. Monalisa, respectivamente, quando se aplicou a dose 1.

\subsubsection{Análise de crescimento}

\subsubsection{Cultivar Atlantic}

Na tabela do Anexo A pode-se observar que existe uma forte correlação positiva $(0,91)$ entre a massa seca e massa fresca dos tubérculos, fato que indica que podemos trabalhar com uma confiança de $99 \%$ nas análises com a massa fresca de tubérculos. 
Os sinais negativos que aparecem nas correlações apresentadas nesta tabela se devem ao fato das medições realizadas corresponderem à última data de amostragem (70 DAP), quando a cultura encontrava-se na fase de senescência. Em conseqüência ocorreu queda de folhas que não foram quantificadas completamente, e o número de estolões diminuíram consideravelmente devido à transformação de estolão em tubérculo.

Análise de regressão

O modelo completo foi o seguinte:

$$
\mathrm{Y}=\hat{a}_{0}+\hat{a}_{1} \mathrm{x}_{1}+\hat{a}_{2} \mathrm{x}_{2}+\hat{a}_{3} \mathrm{x}_{3}+\hat{a}_{4} \mathrm{x}_{4}+\hat{a}_{5} \mathrm{x}_{5}+\hat{a}_{6} \mathrm{x}_{6}+\mathrm{a}
$$

em que:

$Y$ - massa fresca dos tubérculos (MFT)

$\mathrm{X}_{1}$ - número de folhas (NF)

$X_{2}$ - área foliar $(A F)$

$X_{3}$ - número de estolões (NE)

$\mathrm{X}_{4}$ - número de tubérculos (NT)

$X_{5}$ - massa seca da parte aérea (MSPA)

$\mathrm{X}_{6}$ - massa seca das raízes (MSR)

$\varepsilon$ - erro aleatório

O resultado da primeira análise foi o seguinte:

\begin{tabular}{ccc}
\hline $\mathrm{R}^{2}$ & $\mathrm{R}^{2}$ ajustado & Estimativa do erro padrão \\
\hline 0,639 & 0,512 & 0,6985 \\
\hline
\end{tabular}


Pode-se observar um bom ajuste com um coeficiente de determinação igual a 0,639 .

A análise de variância mostrou que houve diferença significativa pelo teste $\mathrm{F}$ ao nível de $1 \%$, observando-se que o modelo satisfaz a uma significância de $5 \%$.

O detalhamento da análise de variância das variáveis em estudo é apresentada na Tabela 32.

Tabela 32. Análise de variância do número de folhas (NF), área foliar (AF), número de estolões (NE), número de tubérculos (NT), massa seca da parte aérea (MSPA), massa seca das raízes (MSR) do cv. Atlantic no experimento II

\begin{tabular}{|c|c|c|c|c|c|}
\hline & \multicolumn{2}{|c|}{ Coeficiente não estandarizado } & \multirow{2}{*}{$\begin{array}{c}\begin{array}{c}\text { Coeficiente } \\
\text { estandarizado }\end{array} \\
\beta\end{array}$} & \multirow[t]{2}{*}{$\mathrm{t}$} & \multirow{2}{*}{$\alpha$} \\
\hline & $\beta$ & Erro padrão & & & \\
\hline (Constante) & $1,566 \times 10-6$ & 0,143 & & 0,000 & 1,000 \\
\hline NF & $-0,716$ & 0,278 & $-0,716$ & $-2,579$ & 0,019 \\
\hline$A F$ & 0,913 & 0,446 & 0,913 & 2,047 & 0,056 \\
\hline NE & $-0,362$ & 0,185 & $-0,362$ & $-1,959$ & 0,067 \\
\hline NT & 0,302 & 0,195 & 0,302 & 1,546 & 0,140 \\
\hline MSPA & 0,270 & 0,294 & 0,270 & 0,918 & 0,372 \\
\hline MSR & $-0,093$ & 0,206 & $-0,093$ & $-0,454$ & 0,655 \\
\hline
\end{tabular}

Pode-se observar que as variáveis número de folhas, área foliar, e número de estolões foram significativas ao nível de $5 \%$ de significância.

Ajustando o modelo considerando unicamente as variáveis significativas temos.

$\mathrm{Y}=\hat{a}_{0}+\hat{a}_{1} \mathrm{x}_{1}+\hat{a}_{2} \mathrm{x}_{2}+\hat{a}_{3} \mathrm{x}_{3}+\mathrm{a}$

em que:

$Y$ - massa fresca dos tubérculos (MFT)

$\mathrm{X}_{1}$ - número de folhas (NF)

$\mathrm{X}_{2}$-área foliar (AF) 
$\mathrm{X}_{3}$ - número de estolões (NE)

$\varepsilon$ - erro aleatório

O resultado desse módulo foi a seguinte:

\begin{tabular}{ccc}
\hline$R^{2}$ & $R^{2}$ ajustado & Estimativa do erro padrão \\
\hline 0,582 & 0,519 & 0,6936 \\
\hline
\end{tabular}

O coeficiente de determinação foi de 0,582 indicando que o modelo explica boa parte dos dados.

A análise de variância mostrou que houve diferença significativa pelo teste $\mathrm{F}$, ao nível de $1 \%$, com respeito a NF, NE, e AF. O detalhamento da análise de variância para as três variáveis é apresentado na Tabela 33.

Tabela 33. Análise de variância de número de folhas (NF), área foliar (AF), número de estolões (NE), do cv. Atlantic no experimento II

\begin{tabular}{|c|c|c|c|c|c|}
\hline & \multicolumn{2}{|c|}{$\begin{array}{l}\text { Coeficiente não } \\
\text { estandarizado }\end{array}$} & \multirow{2}{*}{$\begin{array}{c}\begin{array}{c}\text { Coeficiente } \\
\text { estandarizado }\end{array} \\
\beta \\
\end{array}$} & \multirow[t]{2}{*}{$\mathrm{t}$} & \multirow[t]{2}{*}{$\alpha$} \\
\hline & $\beta$ & Erro padrão & & & \\
\hline (Constante) & $2,827 \times 10-6$ & 0,142 & & 0,000 & 1,000 \\
\hline NF & $-0,879$ & 0,229 & $-0,879$ & $-3,843$ & 0,001 \\
\hline AF & 1,301 & 0,247 & 1,301 & 5,260 & 0,000 \\
\hline NE & $-0,410$ & 0,166 & $-0,410$ & $-2,474$ & 0,022 \\
\hline
\end{tabular}

Observa-se que as variáveis NF, AF, e NE são significativas a $95 \%$ de confiança. Quer dizer que estas variáveis são as que influenciam na massa fresca de tubérculos, refletindo na produção total.

Como conseqüência da senescência das plantas deixou-se de quantificar com precisão o número de folhas; assim as folhas que ficaram desenvolveram-se em tamanho, implicando em maior área foliar, que foi responsável pela fotossíntese e translocação de fotosintetizados para a formação dos tubérculos.

A diminuição do número de estolões na última data de amostragem se deve ao fato de que os estolões, que foram numerosos no princípio, foram 
transformando-se em tubérculos, permanecendo somente aqueles que se formaram ao final do ciclo da cultura.

\subsubsection{Cultivar Jatte-Bintje}

Observa-se na tabela do Anexo C uma forte correlação positiva $(0,931)$ entre a massa fresca e massa seca de tubérculo. Nessa matriz de correlação observa-se que as variáveis têm maior correlação com a massa fresca.

Análise de regressão

O modelo completo foi o seguinte:

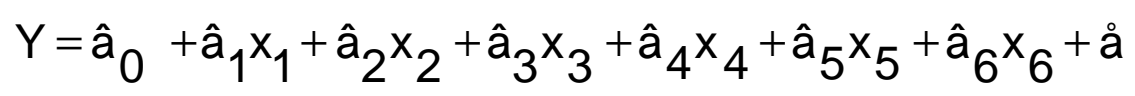

em que:

Y- massa fresca dos tubérculos (MFT)

$\mathrm{X}_{1}$ - número de folhas (NF)

$\mathrm{X}_{2}$ - área foliar $(\mathrm{AF})$

$\mathrm{X}_{3}$ - número de estolões (NE)

$\mathrm{X}_{4}$ - número de tubérculos (NT)

$X_{5}$ - massa seca da parte aérea (MSPA)

$\mathrm{X}_{6}$ - massa seca das raízes (MSR)

$\varepsilon$ - erro aleatório

O resumo do modelo da análise foi o seguinte: 


\begin{tabular}{ccc}
\hline $\mathrm{R}^{2}$ & $\mathrm{R}^{2}$ ajustado & Estimativa do erro padrão \\
\hline 0,877 & 0,834 & 0,4071 \\
\hline
\end{tabular}

O resultado da análise indica que o coeficiente de determinação é ótimo $(0,877)$, o que significa que os dados observados e a média dos mesmos não tiveram muita variação entre si.

A análise de variância mostrou que houve diferença significativa pelo teste $\mathrm{F}$ ao nível de $1 \%$ com respeito के variáveis em estudo. $\mathrm{O}$ detalhamento da análise de variância das variáveis NF, AF, NE, NT, MSPA, e MSR é apresentado na Tabela 34.

Tabela 34. Análise de variância do número de folhas (NF), área foliar (AF), número de estolões (NE), número de tubérculos (NT), massa seca da parte aérea (MSPA), massa seca das raízes (MSR) do cv. JatteBintje no experimento II

\begin{tabular}{|c|c|c|c|c|c|}
\hline & \multicolumn{2}{|c|}{ Coeficiente não estandarizado } & \multirow{2}{*}{$\begin{array}{c}\begin{array}{c}\text { Coeficiente } \\
\text { estandarizado }\end{array} \\
\beta\end{array}$} & \multirow[t]{2}{*}{$\mathrm{t}$} & \multirow[t]{2}{*}{$\alpha$} \\
\hline & $\beta$ & Erro padrão & & & \\
\hline (Constante) & $2,944 \times 10^{-5}$ & 0,083 & & 0,000 & 1,000 \\
\hline NF & $-0,614$ & 0,960 & $-0,614$ & $-6,418$ & 0,000 \\
\hline $\mathrm{AF}$ & $-0,077$ & 0,216 & $-0,077$ & $-0,356$ & 0,726 \\
\hline NE & $-0,214$ & 0,125 & $-0,214$ & $-1,713$ & 0,105 \\
\hline NT & 0,118 & 0,125 & 0,118 & 0,948 & 0,357 \\
\hline MSPA & 0,913 & 0,204 & 0,913 & 4,476 & 0,000 \\
\hline MSR & 0,362 & 0,149 & 0,362 & 2,423 & 0,027 \\
\hline
\end{tabular}

Pode-se observar que as variáveis NF, MSPA, e MSR foram significativas. Ajustando o modelo considerando unicamente as variáveis significativas temos:

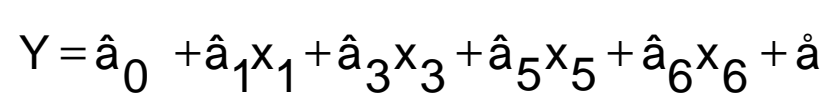


em que:

$\mathrm{Y}$ - massa fresca dos tubérculos (MFT)

$\mathrm{X}_{1}$ - número de folhas (NF)

$\mathrm{X}_{3}$ - número de estolões (NE)

$\mathrm{X}_{5}$ - massa seca da parte aérea (MSPA)

$\mathrm{X}_{6}$ - massa seca das raízes (MSR)

$\varepsilon$ - erro aleatório

O resultado desse modelo foi o seguinte:

\begin{tabular}{ccc}
\hline$R^{2}$ & $R^{2}$ ajustado & Estimativa do erro padrão \\
\hline 0,865 & 0,837 & 0,4038 \\
\hline
\end{tabular}

O coeficiente de determinação foi de 0,84 o que indica que o modelo explica boa parte dos dados das variáveis em estudo.

A análise de variância pelo teste $F$ foi significativa ao nível de $1 \%$ com respeito às variáveis em estudo. $O$ detalhamento da análise de variância das variáveis NF, NE, MSPA, e MSR apresenta-se na Tabela 35.

Tabela 35. Análise de variância de número de folhas (NF), número de estolões (NE), massa seca da parte aérea (MSPA), e massa seca das raízes (MSR) do cv. Jatte-Bintje no experimento II

\begin{tabular}{|c|c|c|c|c|c|}
\hline & \multicolumn{2}{|c|}{ Coeficiente não estandarizado } & \multirow{2}{*}{$\begin{array}{c}\begin{array}{c}\text { Coeficiente } \\
\text { estandarizado }\end{array} \\
\beta \\
\end{array}$} & \multirow[t]{2}{*}{$\mathrm{t}$} & \multirow[t]{2}{*}{$\alpha$} \\
\hline & $\beta$ & Erro padrão & & & \\
\hline (Constante) & $3,313 \times 10^{-5}$ & 0,082 & & 0,000 & 1,000 \\
\hline NF & $-0,625$ & 0,094 & $-0,625$ & $-6,621$ & 0,000 \\
\hline NE & $-0,290$ & 0,105 & $-0,290$ & $-2,763$ & 0,012 \\
\hline MSPA & 0,876 & 0,099 & 0,876 & 8,805 & 0,000 \\
\hline MSR & 0,430 & 0,101 & 0,430 & 4,242 & 0,000 \\
\hline
\end{tabular}

$\mathrm{Na}$ Tabela 35 observa-se que todas as variáveis foram significativas ao nível de confiança de $99 \%$. Portanto essas variáveis são as que influenciam mais na massa fresca de tubérculos no cv. Jatte-Bintje. 


\subsubsection{Cultivar Monalisa}

$\mathrm{Na}$ tabela do Anexo E pode-se observar que existe uma forte correlação positiva $(0,977)$ entre a massa seca e a massa fresca dos tubérculos, fato que indica que podemos trabalhar com uma confiança de $99 \%$ nas análises com a massa fresca de tubérculos.

Análise de regressão

O modelo completo foi o seguinte:

$$
Y=\hat{a}_{0}+\hat{a}_{1} x_{1}+\hat{a}_{2} x_{2}+\hat{a}_{3} x_{3}+\hat{a}_{4} x_{4}+\hat{a}_{5} x_{5}+\hat{a}_{6} x_{6}+a ̊
$$

em que:

$Y$ - massa fresca dos tubérculos (MFT)

$\mathrm{X}_{1}$ - número de folhas (NF)

$\mathrm{X}_{2}$ - área foliar (AF)

$\mathrm{X}_{3}$ - número de estolões (NE)

$\mathrm{X}_{4}$ - número de tubérculos (NT)

$X_{5}$ - massa seca da parte aérea (MSPA)

$\mathrm{X}_{6}$ - massa seca das raízes (MSR)

$\varepsilon$ - erro aleatório

O resumo do modelo da análise foi o seguinte: 
Pode-se observar um coeficiente de determinação de 0,793 , considerado razoavelmente bom. A análise de variância mostrou que houve diferença significativa pelo teste $\mathrm{F}$ ao nível de $1 \%$. Pode-se observar um bom ajuste do modelo considerando uma significância de 5\% no detalhamento da análise de variância das variáveis em estudo que é apresentada na Tabela 36.

Tabela 36. Análise de variância do número de folhas (NF), área foliar (AF), número de estolões (NE), número de tubérculos (NT), massa seca da parte aérea (MSPA) e massa seca das raízes (MSR) do cv. Monalisa no experimento II

\begin{tabular}{|c|c|c|c|c|c|}
\hline & \multicolumn{2}{|c|}{$\begin{array}{l}\text { Coeficiente não } \\
\text { estandarizado }\end{array}$} & \multirow{2}{*}{$\begin{array}{c}\begin{array}{c}\text { Coeficiente } \\
\text { estandarizado }\end{array} \\
\beta\end{array}$} & \multirow[t]{2}{*}{$\mathrm{t}$} & \multirow[t]{2}{*}{$\alpha$} \\
\hline & $\beta$ & Erro padrão & & & \\
\hline (Constante) & $1,711 \times 10^{-6}$ & 0,108 & & 0,000 & 1,000 \\
\hline NF & $-0,403$ & 0,141 & $-0,403$ & $-2,857$ & 0,011 \\
\hline $\mathrm{AF}$ & 0,720 & 0,173 & 0,720 & 4,164 & 0,001 \\
\hline NE & $-0,150$ & 0,124 & $-0,150$ & $-1,214$ & 0,241 \\
\hline NT & 0,307 & 0,151 & 0,307 & 2,038 & 0,057 \\
\hline MSPA & 0,099 & 0,136 & 0,099 & 0,723 & 0,479 \\
\hline MSR & 0,070 & 0,164 & 0,070 & 0,429 & 0.673 \\
\hline
\end{tabular}

Pode-se observar que as variáveis NF, AF, e NT foram significativas a 95\% de confiança. Assim, ajustando o modelo considerando somente as variáveis significativas temos:

$\mathrm{Y}=\hat{a}_{0}+\hat{a}_{1} \mathrm{x}_{1}+\hat{\mathrm{a}}_{2} \mathrm{x}_{2}+\hat{a}_{4} \mathrm{x}_{4}+\mathrm{a}$

em que:

$Y$ - massa fresca dos tubérculos (MFT)

$\mathrm{X}_{1}$ - número de folhas (NF)

$X_{2}$ - área foliar (AF)

$\mathrm{X}_{4}$ - número de tubérculos (NT) 
$\varepsilon$ - erro aleatório

O resultado desse modelo foi o seguinte:

\begin{tabular}{ccc}
\hline $\mathrm{R}^{2}$ & $\mathrm{R}^{2}$ ajustado & Estimativa do erro padrão \\
\hline 0,770 & 0,736 & 0,5138 \\
\hline
\end{tabular}

Pode-se observar um coeficiente de determinação de 0,770 , considerado razoavelmente bom, significando que o modelo explica boa parte das variáveis.

A análise de variância mostrou que houve diferença significativa pelo teste $\mathrm{F}$ ao nível de $1 \%$. Pode-se observar um bom ajuste do modelo considerando uma significância de $5 \%$ no detalhamento da análise de variância das variáveis em estudo, que é apresentada na Tabela 37.

Tabela 37. Análise de variância de número de folhas (NF), área foliar (AF) e número de tubérculos (NT) do cv. Monalisa no experimento II

\begin{tabular}{|c|c|c|c|c|c|}
\hline & \multicolumn{2}{|c|}{$\begin{array}{c}\text { Coeficiente não } \\
\text { estandarizado }\end{array}$} & \multirow{2}{*}{$\begin{array}{c}\begin{array}{c}\text { Coeficiente } \\
\text { estandarizado }\end{array} \\
\beta\end{array}$} & \multirow[t]{2}{*}{$\mathrm{t}$} & \multirow[t]{2}{*}{$\alpha$} \\
\hline & $\beta$ & Erro padrão & & & \\
\hline (Constante) & $-1,21 \times 10^{-6}$ & 0,105 & & 0,000 & 1,000 \\
\hline NF & $-0,381$ & 0,133 & $-0,381$ & $-2,874$ & 0,009 \\
\hline AF & 0,806 & 0,143 & 0,806 & 5,634 & 0,000 \\
\hline NT & 0,350 & 0,118 & 0,350 & 2,957 & 0,008 \\
\hline
\end{tabular}

$\mathrm{Na}$ Tabela 37 observa-se que todas as variáveis foram significativas ao $99 \%$ de nível de confiança. Portanto essas variáveis são as que influenciam mais na massa fresca do tubérculo no cv. Monalisa.

4.3.7 Análise de variância e comparações múltiplas da produtividade das três cultivares referente às dosagens de $\mathrm{CO}_{2}$ 


\subsubsection{Cultivar Atlantic}

Modelo proposto para Análise de variância

$$
Y_{i j}=\grave{i}+\hat{o}_{i}+\stackrel{a}{i j}_{i j}
$$

em que:

$\mathrm{i}=1,2,3 \mathrm{j}=1,2,3,4$

$\mathrm{y}_{\mathrm{ij}}$ - ij-ésima observação;

$\mu$ - parâmetro comum a todos os tratamentos denominado de média global;

$\tau_{\mathrm{i}}$ - parâmetro único para o i-ésimo tratamento; e

$\varepsilon_{\mathrm{ij}}$ - componente aleatório do erro.

Pode-se observar nos Anexos $\mathrm{G}$ e $\mathrm{H}$ a análise exploratória com o teste de homogeneidade, assim como as análises dos resíduos, onde se verifica que os pressupostos do modelo estão sendo satisfeitos.

A análise de variância para a variável produção total de batata (Tabela 38) indica que não houve diferença significativa, pelo teste $F$, entre as dosagens de $\mathrm{CO}_{2}$ ao nível de $5 \%$.

Tabela 38. Análise de variância de produção total de batata cv. Atlantic em função das doses de $\mathrm{CO}_{2}$ no experimento II

\begin{tabular}{lccccc}
\hline & $\begin{array}{c}\text { Soma de } \\
\text { quadrados }\end{array}$ & $\begin{array}{c}\text { Graus de } \\
\text { liberdade }\end{array}$ & $\begin{array}{c}\text { Quadrado } \\
\text { médio }\end{array}$ & $F$ & $\alpha$ \\
\hline Entre dosagens & 59,140 & 2 & 29,570 & 3,177 & 0,090 \\
Dentro de dosagens & 83,756 & 9 & 9,306 & & \\
Total & 142,896 & 11 & & & \\
\hline \multicolumn{4}{c}{ Se for considerada a um nível de } & $10 \%$, podemos ter evidências de
\end{tabular}

diferença significativa entre os níveis das dosagens com respeito à produção total.

$\mathrm{Na}$ Tabela 39 apresenta-se a análise de comparações múltiplas considerando o método de Tukey. 
Tabela 39. Análise de comparações múltiplas de batata cv. Atlantic entre as doses de $\mathrm{CO}_{2}$ no experimento II

\begin{tabular}{cccccc}
\hline Tukey HSD & $\begin{array}{c}\text { I } \\
\text { (Dose) }\end{array}$ & $\begin{array}{c}\mathrm{J} \\
\text { (Dose) }\end{array}$ & $\begin{array}{c}\text { Diferença de } \\
\text { médias (I-J) }\end{array}$ & Erro padrão & $\alpha$ \\
\hline Dose 1 & Dose 2 & 4,8600 & 2,157 & 0,115 \\
& Dose 3 & 4,5425 & 2,157 & 0,143 \\
& Dose 2 & Dose 1 & $-4,8600$ & 2,157 & 0,115 \\
& Dose 3 & $-0,3175$ & 2,157 & 0,988 \\
& Dose 3 & Dose 1 & $-4,5425$ & 2,157 & 0,143 \\
& Dose 2 & 0,3175 & 2,157 & 0,988 \\
\hline
\end{tabular}

Pode-se observar uma forte evidência de diferença significativa da dose 1 com as doses 2 e 3 com respeito a produção total a um nível de $15 \%$ de significância. Já entre as doses 2 e 3 não existe variação alguma.

\subsubsection{Cultivar Jatte-Bintje}

Nos Anexos I e J pode-se observar a análise exploratória, onde se verifica que os pressupostos do modelo estão sendo satisfeitos.

A análise de variância para a produção total de batata do cultivar JatteBintje (Tabela 40) mostra que houve diferença significativa, pelo teste $F$, entre as dosagens de $\mathrm{CO}_{2}$ ao nível de $5 \%$.

Tabela 40. Análise de variância de produção total de batata cv. Jatte-Bintje em função das doses de $\mathrm{CO}_{2}$ no experimento II

\begin{tabular}{lccccc}
\hline & $\begin{array}{c}\text { Soma de } \\
\text { quadrados }\end{array}$ & $\begin{array}{c}\text { Graus de } \\
\text { liberdade }\end{array}$ & $\begin{array}{c}\text { Quadrado } \\
\text { médio }\end{array}$ & $\mathrm{F}$ & $\alpha$ \\
\hline Entre dosagens & 46,359 & 2 & 23,180 & 17,008 & 0,001 \\
Dentro de dosagens & 12,266 & 9 & 1,363 & & \\
Total & 58,625 & 11 & & & \\
\hline
\end{tabular}


O detalhamento da análise, por meio de comparações múltiplas pelo teste de Tukey, é apresentado na Tabela 41.

Tabela 41. Análise de comparações múltiplas de batata cv. Jatte-Bintje entre as doses de $\mathrm{CO}_{2}$ no experimento II

\begin{tabular}{|c|c|c|c|c|c|}
\hline \multirow[t]{7}{*}{ Tukey HSD } & $\begin{array}{c}1 \\
\text { (Dose) }\end{array}$ & $\begin{array}{c}\mathrm{J} \\
\text { (Dose) }\end{array}$ & $\begin{array}{l}\text { Diferença de } \\
\text { médias (I-J) }\end{array}$ & Erro padrão & $\alpha$ \\
\hline & \multirow{2}{*}{ Dose 1} & Dose 2 & $3,2100^{*}$ & 8,25 & 0,009 \\
\hline & & Dose 3 & $4,7125^{\star}$ & 8,25 & 0,001 \\
\hline & \multirow[t]{2}{*}{ Dose 2} & Dose 1 & $-3,2100^{*}$ & 8,25 & 0,009 \\
\hline & & Dose 3 & 1,5025 & 8,25 & 0,218 \\
\hline & \multirow[t]{2}{*}{ Dose 3} & Dose 1 & $-4,7125^{*}$ & 8,25 & 0,001 \\
\hline & & Dose 2 & $-1,5025$ & 8.25 & 0.218 \\
\hline
\end{tabular}

Pode-se observar que existe diferença significativa entre a dose 1 e a dose 2 e entre a dose 1 e a dose 3 com respeito a produção total a um nível de $5 \%$ de significância, enquanto as doses 2 e 3 não variaram significativamente entre si.

\subsubsection{Cultivar Monalisa}

A análise gráfica dos resíduos, apresentada nos Anexos $\mathrm{K} \mathrm{e} \mathrm{L} \mathrm{permite}$ afirmar que as pressuposições de normalidade (pelos intervalos dos resíduos padronizados) e também de homogeneidade de variâncias foram satisfeitos.

A análise de variância para a produção total de batata do cultivar Monalisa (Tabela 42) mostra que não houve diferença significativa, pelo teste $F$, entre as dosagens de $\mathrm{CO}_{2}$ ao nível de $5 \%$.

Tabela 42. Análise de variância de produção total de batata cv. Monalisa em função das doses de $\mathrm{CO}_{2}$ no experimento II

\begin{tabular}{lccccc}
\hline & $\begin{array}{c}\text { Soma de } \\
\text { quadrados }\end{array}$ & $\begin{array}{c}\text { Graus de } \\
\text { liberdade }\end{array}$ & $\begin{array}{c}\text { Quadrado } \\
\text { médio }\end{array}$ & $\mathrm{F}$ & $\alpha$ \\
\hline Entre dosagens & 39,105 & 2 & 19,552 & 2,834 & 0,111 \\
Dentro de dosagens & 62,083 & 9 & 6,898 & & \\
Total & 101,188 & 11 & & & \\
\hline
\end{tabular}


O detalhamento da análise, por meio de comparações múltiplas pelo teste de Tukey, é apresentado na Tabela 43.

Tabela 43. Análise de comparações múltiplas de batata cv. Monalisa entre as doses de $\mathrm{CO}_{2}$ no experimento II

\begin{tabular}{cccccc}
\hline Tukey HSD & I & $\begin{array}{c}\text { J } \\
\text { (Dose) }\end{array}$ & $\begin{array}{c}\text { Diferença de } \\
\text { médias (I-J) }\end{array}$ & Erro padrão & $\alpha$ \\
& Dose 1 & Dose 2 & 4,0200 & 18,57 & 0,131 \\
& Dose 3 & 3,6050 & 18,57 & 0,183 \\
& Dose 2 & Dose 1 & $-4,0200$ & 18,57 & 0,131 \\
& Dose 3 & $-0,4150$ & 18,57 & 0,973 \\
& \multirow{2}{*}{ Dose 3 } & Dose 1 & $-3,6050$ & 18,57 & 0,183 \\
& & Dose 2 & 0,4150 & 18,57 & 0,973 \\
\hline
\end{tabular}

Pode-se observar que se considerarmos um nível de confiança de $85 \%$ teríamos fortes evidências de que existe diferença significativa entre as dose $1 \mathrm{e}$ dose 2 com respeito a produção total.

\subsubsection{Produtividade total dos tubérculos}

Os valores de produtividade encontrados para os cultivares (Tabela 44) que não receberam tratamento com $\mathrm{CO}_{2}$ variaram entre 19,12 a 22,09 $\mathrm{t} \mathrm{ha}^{-1}$. Comparando-se a produtividade das médias dos cultivares de batata observa-se que o cultivar Monalisa apresentou o maior valor $\left(19,55 \mathrm{t} \mathrm{ha}^{-1}\right)$ em média independente das dosagens de $\mathrm{CO}_{2}$, seguido pelo cultivar Jatte-Bintje que não diferiu significativamente entre si, e o cultivar Atlantic apresentou o menor valor $\left(15,89\right.$ t ha $\left.^{-1}\right)$ em média.

Verifica-se pela Tabela 44 que para os três cultivares foi observada diferença estatisticamente significativa entre a produtividade da amostra não tratada e a produtividade das amostras tratadas $\operatorname{com} \mathrm{CO}_{2}$. A aplicação das dosagens de $\mathrm{CO}_{2}$ tendeu a reduzir a produtividade nos três cultivares, sendo que 
as aplicações de $\mathrm{CO}_{2}$ não apresentaram diferença estatística significativa entre si.

Tabela 44. Médias originais de produtividade total nas três cultivares de batata em função das doses de $\mathrm{CO}_{2}$ no experimento II

\begin{tabular}{cccc}
\hline \multirow{2}{*}{ Tratamentos } & \multicolumn{3}{c}{ Produtividade total de batata (t ha ${ }^{-1}$ ) } \\
& Atlantic & Jatte-Bintje & Monalisa \\
\hline T1 & $19,12 \mathrm{a}$ & $20,67 \mathrm{a}$ & $22,09 \mathrm{a}$ \\
T2 & $14,12 \mathrm{~b}$ & $17,46 \mathrm{~b}$ & $18,07 \mathrm{~b}$ \\
T3 & $14,44 \mathrm{~b}$ & $15,96 \mathrm{~b}$ & $18,48 \mathrm{~b}$ \\
Média & $\mathbf{1 5 , 8 9 B}$ & $\mathbf{1 8 , 0 3 A}$ & $\mathbf{1 9 , 5 5 A}$ \\
\hline $\begin{array}{l}\text { Médias seguidas por letras minúsculas distintas nas colunas e letras maísculas nas linhas, diferem entre si pelo } \\
\text { teste de Tukey ao nível de } 5 \%\end{array}$
\end{tabular}

Na Figura 37 é apresentada o gráfico das médias de produtividade dos três cultivares em função das três dosagens, onde se observa que com a dose 1 (sem aplicação de $\mathrm{CO}_{2}$ ) a produtividade de batata foi superior, nos três

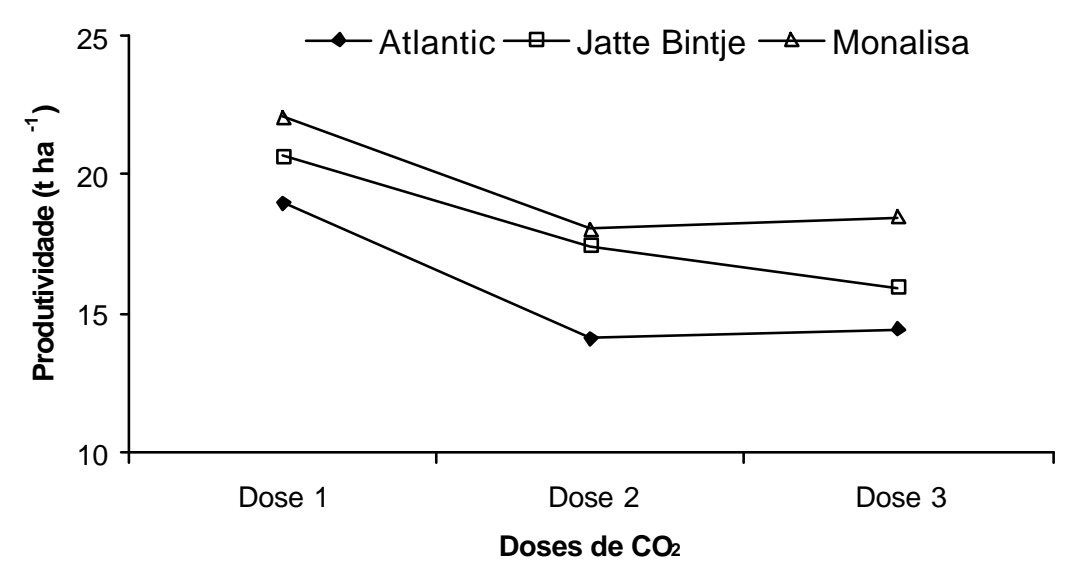

Figura 37 - Curvas das médias de produtividade dos cultivares de batata em função das doses de $\mathrm{CO}_{2}$ (T1-0; T2- 145,36; T3-290,72 $\left.\mathrm{kg} \mathrm{ha}^{-1}\right)$ no experimento II

cultivares, aos tratamentos com aplicação de $\mathrm{CO}_{2}$, indicando, que a medida em que se incrementa as doses de $\mathrm{CO}_{2}$, a produtividade tende a diminuir nos três cultivares. 


\subsubsection{Classificação comercial de batata dos três cultivares referente às três dosagens de $\mathrm{CO}_{2}$}

O quadro de análise de variância mostrou que não houve diferença significativa, pelo teste $\mathrm{F}$, entre os níveis de $\mathrm{CO}_{2}$ ao nível de $5 \%$ dentro de cada classe. Entretanto, houve diferença significativa entre os cultivares ao nível de 5\%, assim como entre classes, independente das doses de $\mathrm{CO}_{2}$. O detalhamento da análise, por meio do teste de Tukey, está apresentado na Tabela 45.

Tabela 45. Médias originais da classificação comercial e descarte (\%) dos cultivares de batata no experimento II

\begin{tabular}{|c|c|c|c|c|c|}
\hline \multirow{2}{*}{ Cultivares } & \multicolumn{4}{|c|}{ classificação comercial da batata } & \multirow{2}{*}{ Descarte } \\
\hline & Especial & Primeira & Segunda & Miudinha & \\
\hline & & $8,28 c$ & $1,24 \mathrm{c}$ & $0,23 c$ & \\
\hline Jatte-Bintje & $51,42 \mathrm{c}$ & $33,31 a$ & $8,54 a$ & $1,41 \mathrm{a}$ & $5,32 \mathrm{a}$ \\
\hline Monalisa & $79,51 b$ & $16,75 b$ & $2,46 b$ & $0,62 b$ & $0,66 \mathrm{~b}$ \\
\hline
\end{tabular}

Médias seguidas por letras distintas nas colunas diferementre si pelo teste de Tukey ao nível de $5 \%$

Observa-se na Tabela 45 que quase $90 \%$ da produção do cultivar Atlantic correspondeu à classificação especial e um pouco mais de $8 \%$ à primeira. Este mesmo comportamento foi observado no cultivar Monalisa. Já no cultivar JatteBintje, $50 \%$ da produção esteve na classificação especial e um pouco mais de $30 \%$ foi classificado como de primeira.

A Figura 38 permite visualizar o comportamento da classificação percentual nos três cultivares de batata. 


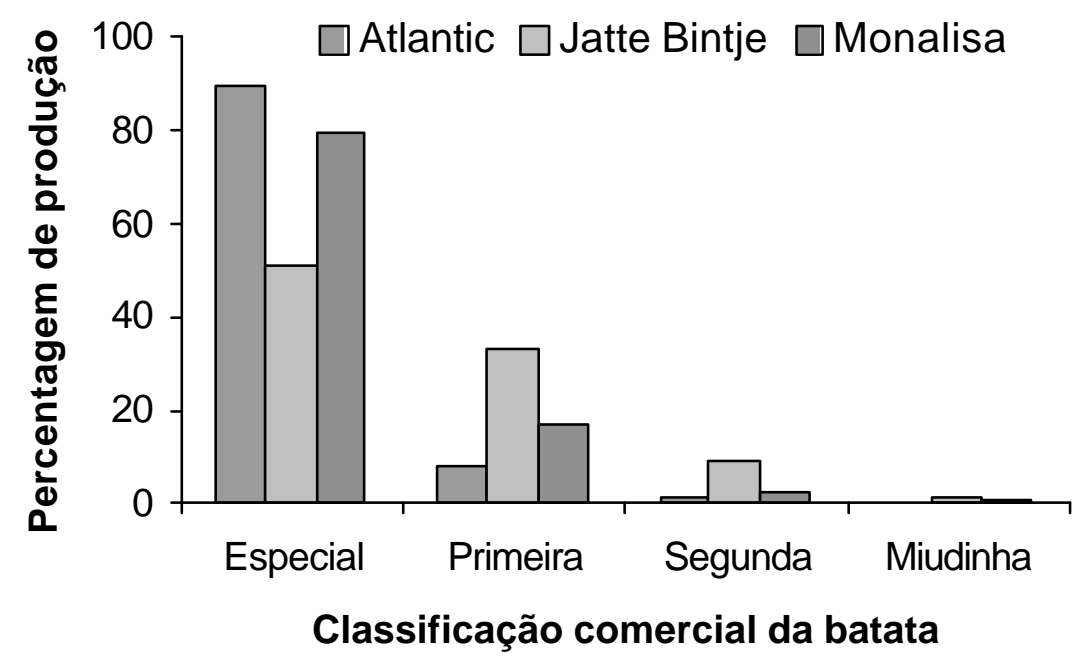

Figura 38 - Classificação comercial dos cultivares de batata (\%)

\subsubsection{Características tecnológicas dos tubérculos}

\subsubsection{1 $\mathrm{pH}$ dos tubérculos}

$\mathrm{O}$ índice $\mathrm{pH}$ avalia fundamentalmente a possibilidade de ocorrer deterioração do alimento pelo desenvolvimento de microrganismos e também determina a atividade das enzimas presentes no mesmo (Cecchi, 1999). Quanto mais elevado o valor de $\mathrm{pH}$, menor a probabilidade de ter ocorrido fermentação (Lehninger, 1988).

Os valores de $\mathrm{pH}$ (Tabela 46) dos tubérculos dos cultivares de batata sem aplicação de $\mathrm{CO}_{2}$ variaram entre 6,43 e 6,50. Tais valores são superiores aos encontrados na literatura. Paschoalino et al. (1983) avaliaram seis cultivares de batata, obtendo uma oscilação nos valores de pH entre 5,1 a 6,2. Já Feltran (2002), encontrou valores de pH 5,57 para 'Bintje' e 5,68 para 'Itararé'. Os valores 
de $\mathrm{pH}$ encontrados no presente experimento indicaram que os tubérculos se encontravam em bom estado de conservação.

Tabela 46. Valores médios de $\mathrm{pH}$ dos tubérculos para os cultivares de batata utilizados segundo diferentes tratamentos (T1 - 0; T2 - 145,36; $\mathrm{T} 3-290,72 \mathrm{~kg} \mathrm{ha}^{-1}$ de $\mathrm{CO}_{2}$ )

\begin{tabular}{cccc}
\hline Tratamento & Atlantic & Jatte-Bintje & Monalisa \\
\hline T1 & $6,43 \mathrm{a}$ & $6,46 \mathrm{a}$ & $6,50 \mathrm{a}$ \\
T2 & $6,46 \mathrm{a}$ & $6,49 \mathrm{a}$ & $6,46 \mathrm{a}$ \\
T3 & $6,46 \mathrm{a}$ & $6,40 \mathrm{a}$ & $6,57 \mathrm{a}$ \\
Médias & $\mathbf{6 , 4 5 \mathrm { A }}$ & $\mathbf{6 , 4 5 \mathrm { A }}$ & $\mathbf{6 , 5 1 \mathrm { A }}$ \\
\hline
\end{tabular}

Médias seguidas por letras minúsculas iguais nas colunas e por letras maiúsculas nas linhas não diferem entre si pelo teste de Tukey em nível de $5 \%$

Os tubérculos dos diferentes cultivares apresentaram valores de $\mathrm{pH}$ que não diferiram significativamente entre si, pelo teste $\mathrm{F}$, em nível de $5 \%$. Dentro de cada cultivar também não foi observada diferença estatisticamente significativa entre as amostras não tratadas ou tratadas com diferentes dosagens de $\mathrm{CO}_{2}$.

\subsubsection{Acidéz titulável}

Os ácidos orgânicos, dentre outros componentes dos vegetais, contribuem grandemente para o sabor e odor dos alimentos (Donnelly et al., 2001c).

A acidez titulável (Tabela 47) apresentada pelos tubérculos de batata dos três cultivares sem o tratamento com o $\mathrm{CO}_{2}$ variaram entre 0,184 e 0,201\%. Estes valores são ligeiramente superiores aos encontrados por Feltran (2002), que foram 0,170; 0,160; 0,165\% de acidez titulável para as cultivares Aracy, Bintje e Itararé, respectivamente. 
Tabela 47. Valores médios de acidez titulável dos tubérculos para os cultivares de batata utilizados segundo diferentes tratamentos (T1 - 0; T2 - 145,36; T3 - 290,72 $\mathrm{kg} \mathrm{ha}^{-1}$ de $\mathrm{CO}_{2}$ )

\begin{tabular}{|c|c|c|c|}
\hline \multirow[t]{2}{*}{ Tratamento } & \multicolumn{3}{|c|}{ Acidez titulável (\% ác. cítrico) } \\
\hline & Atlantic & Jatte-Bintje & Monalisa \\
\hline $\mathrm{T} 1$ & $0,194 a$ & $0,201 a$ & $0,184 a$ \\
\hline T2 & $0,193 a$ & $0,185 a$ & $0,175 a$ \\
\hline T3 & $0,176 a$ & $0,223 a$ & $0,168 a$ \\
\hline Médias & $0,188 \mathrm{~A}$ & $0,203 \mathrm{~A}$ & $0,176 \mathrm{~A}$ \\
\hline
\end{tabular}

Médias seguidas por letras minúsculas iguais nas colunas e por letras maiúsculas nas linhas não diferem entre si pelo teste de Tukey em nível de $5 \%$

Os tubérculos de batata apresentaram valores de acidez titulável que não diferiram significativamente entre os cultivares, embora a escala de variação tenha sido Jatte-Bintje $(0,203 \%)$ seguida pelo Atlantic $(0,188 \%)$ e Monalisa $(0,176 \%)$.

\subsubsection{Firmeza}

A firmeza é um parâmetro de qualidade importante, contribuindo para a textura dos alimentos. Os valores de firmeza encontrados para os cultivares (Tabela 48) que não receberam tratamento com $\mathrm{CO}_{2}$ variaram entre $20,41 \times 10^{5} \mathrm{a}$ $21,14 \times 10^{5} \mathrm{~N} \cdot \mathrm{m}^{-2}$. Feltran (2002) reportou para os cultivares de batata Aracy, Bintje e Itararé uma textura de 820, 753, e 832 gf, respectivamente, avaliados por outro instrumento de medida.

Tabela 48. Valores médios de firmeza dos tubérculos para os cultivares de batata utilizados segundo diferentes tratamentos ( $\mathrm{T} 1 \quad-\quad 0$; $\mathrm{T} 2$ - 145,36; T3 - 290,72 $\mathrm{kg} \mathrm{ha}^{-1}$ de $\left.\mathrm{CO}_{2}\right)$

\begin{tabular}{cccc}
\hline Tratamento & \multicolumn{3}{c}{ Firmeza $\left[\mathbf{N} \cdot \mathbf{m}^{-2}\left(\mathbf{x 1 0 ^ { 5 } )}\right)\right.$} \\
Jatte-Bintje & Monalisa \\
\hline T1 & $20,41 \mathrm{a}$ & $21,14 \mathrm{a}$ & $20,44 \mathrm{~b}$ \\
T2 & $20,26 \mathrm{a}$ & $21,18 \mathrm{a}$ & $21,06 \mathrm{a}$ \\
T3 & $19,58 \mathrm{~b}$ & $20,84 \mathrm{a}$ & $18,77 \mathrm{c}$ \\
Médias & $\mathbf{2 0 , 0 8 B}$ & $\mathbf{2 1 , 0 5 A}$ & $\mathbf{2 0 , 0 9 B}$ \\
\hline
\end{tabular}

Médias seguidas por letras minúsculas iguais nas colunas e por letras maiúsculas nas linhas não diferem entre si pelo teste de Tukey em nível de $5 \%$ 
Comparando-se a firmeza das médias dos cultivares de batata observase que o cultivar Jatte-Bintje apresentou os maiores valores $\left(21,05 \times 10^{5} \mathrm{~N} . \mathrm{m}^{-2}\right)$ em média e os cultivares Monalisa e Atlantic os menores valores $\left(20,09 \times 10^{5}\right.$; $20,08 \times 10^{5} \mathrm{~N} \cdot \mathrm{m}^{-2}$ em média, respectivamente).

Verifica-se pela Tabela 48 que para o cv. Jatte-Bintje não foi observada diferença estatisticamente significativa entre a firmeza da amostra não tratada e a firmeza das amostras tratadas com dosagens de $\mathrm{CO}_{2}$. Para os cultivares Monalisa e Atlantic, entretanto, houve diferença significativa (nivel de 5\%) para a firmeza dos tubérculos tratados com diferentes doses de $\mathrm{CO}_{2}$. A aplicação de maior dosagem de $\mathrm{CO}_{2}$ tendeu a reduzir a firmeza dos tubérculos destes 2 cultivares.

\subsubsection{Sólidos solúveis totais}

Os teores de sólidos solúveis totais (Tabela 49) apresentados pelos tubérculos de batata dos três cultivares sem o tratamento com o $\mathrm{CO}_{2}$ variaram entre 5,12 a $6,38 \%$. O valor de $6,38 \%$ do $\mathrm{cv}$. Jatte-Bintje se assemelha ao encontrado por Paschoalino et al. (1983) que foi de 6,3 $\pm 0,5$ e é superior ao encontrado por Feltran (2002) que foi de 5,19\% para o cv. Bintje.

Tabela 49. Sólidos solúveis totais dos tubérculos dos cultivares de batata produzidos sob diferentes tratamentos (T1 - 0; T2 - 145,36; T3 - 290,72 $\mathrm{kg} \mathrm{ha}^{-1}$ de $\mathrm{CO}_{2}$ )

\begin{tabular}{cccc}
\hline Tratamento & Atlantic & $\begin{array}{c}\text { Sólidos solúveis totais (\%) } \\
\text { Jatte-Bintje }\end{array}$ & Monalisa \\
\hline T1 & $5,88 \mathrm{a}$ & $6,38 \mathrm{a}$ & $5,12 \mathrm{a}$ \\
T2 & $6,02 \mathrm{a}$ & $6,26 \mathrm{a}$ & $5,58 \mathrm{a}$ \\
T3 & $5,93 \mathrm{a}$ & $5,97 \mathrm{a}$ & $5,72 \mathrm{a}$ \\
Médias & $\mathbf{5 , 9 4 A}$ & $\mathbf{6 , 2 0 A}$ & $\mathbf{5 , 4 7 B}$ \\
\hline
\end{tabular}

Médias seguidas por letras minúsculas iguais nas colunas e por letras maiúsculas nas linhas não diferem entre si pelo teste de Tukey em nível de 5\% 
A análise de variância para a variável sólidos solúveis totais (Tabela 49) indica que houve diferença significativa (nível de $5 \%$ ), pelo teste $\mathrm{F}$, entre as médias dos cultivares de batata testados. $O$ cultivar Monalisa apresentou a menor média de percentual de sólidos solúveis totais e os cultivares Jatte-Bintje e Atlantic as maiores médias.

O teor de sólidos solúveis totais dos cultivares de batata estudadas não

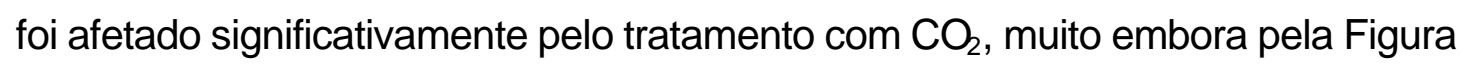
39 possa se visualizar que a tendência dos cultivares frente à aplicação deste composto se mostra diferenciada e a maior dosagem conduz a teores de sólidos mais próximos entre si.

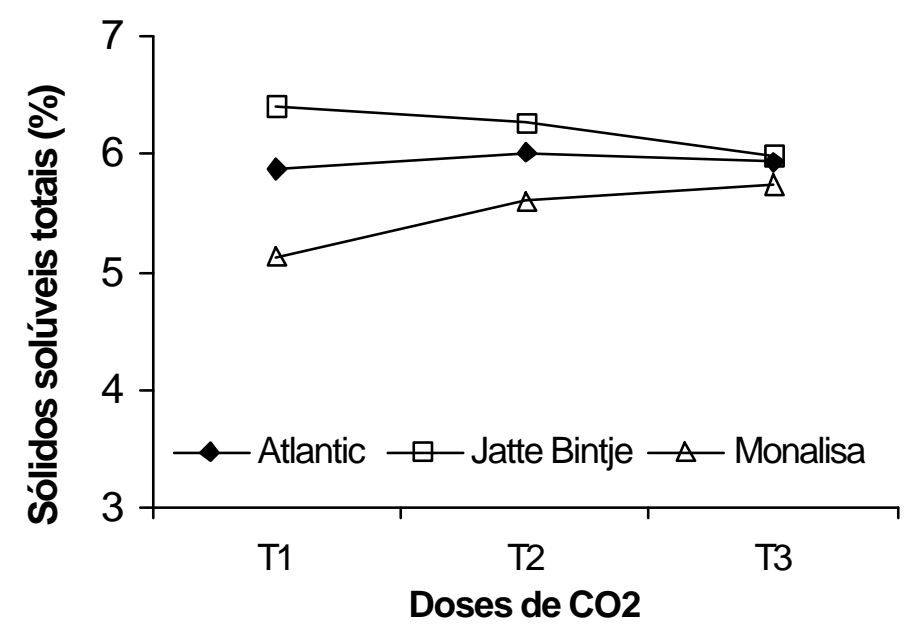

Figura 39 - Percentuais de sólidos solúveis totais (SST) dos cultivares de batata em função dos tratamentos (T1 - 0; T2 - 145,36; T3 - 290,72 $\mathrm{kg} \mathrm{ha}^{-1}$ de $\mathrm{CO}_{2}$ )

\subsubsection{Cor da polpa}

Os valores obtidos para os parâmetros de cor dos tubérculos são apresentados nas Tabelas 50, 51, e 52. A análise de variância para a cor de polpa dos tubérculos de batata indica que houve diferença significativa, pelo teste 
$F$, entre as médias dos cultivares de batata para as variáveis $b^{*}$ e $a^{*}$, em nível de $5 \%$. Ocorreram também diferenças significativas entre as dosagens de $\mathrm{CO}_{2}$ utilizadas para as variáveis $L^{*} e b^{*}$.

Tabela 50. Valores médios de luminosidade $\left(L^{*}\right)$ da polpa dos tubérculos de cultivares de batata produzidas sob diferentes tratamentos (T1 - 0; T2 - 145,36; T3- 290,72 $\mathrm{kg} \mathrm{ha}^{-1}$ de $\mathrm{CO}_{2}$ )

\begin{tabular}{cccc}
\hline \multirow{2}{*}{ Tratamento } & \multicolumn{3}{c}{ Luminosidade da polpa dos tubérculos } \\
& Atlantic & Jatte-Bintje & Monalisa \\
\hline T1 & $68,82 \mathrm{~b}$ & $66,80 \mathrm{~b}$ & $69,41 \mathrm{a}$ \\
T2 & $72,06 \mathrm{a}$ & $68,54 \mathrm{~b}$ & $69,73 \mathrm{a}$ \\
T3 & $69,39 \mathrm{~b}$ & $70,13 \mathrm{a}$ & $68,27 \mathrm{a}$
\end{tabular}

\section{Médias}

$70,09 \mathrm{~A}$

$68,49 \mathrm{~A}$

$69,14 \mathrm{~A}$

Médias seguidas por letras minúsculas iguais nas colunas e por letras maiúsculas nas linhas não diferem entre si pelo teste de Tukey em nível de $5 \%$

Sendo: $L$ (escala de 0 a 100)

Os valores de luminosidade da polpa dos tubérculos de batata não tratados com $\mathrm{CO}_{2}$ variaram entre 66,80 e 69,41. Estes valores indicam que a coloração da polpa, numa escala de 0 a 100, apresentou tendência mais para o claro que para escuro, conforme o esperado para estes vegetais.

Ao se comparar as médias dos cultivares de batata observa-se que a variável $L^{*}$ nos três cultivares não variou significativamente. Entretanto, pela Tabela 50, dentro dos cultivares, observa-se efeito do nível de aplicação de $\mathrm{CO}_{2}$ para os cultivares Atlantic e Jatte-Bintje. A menor dosagem (145,36 $\mathrm{kg} \mathrm{ha}^{-1}$ ) de $\mathrm{CO}_{2}$ tornou os tubérculos do $\mathrm{cv}$. Atlantic mais claros que os demais tratamentos e a dosagem maior $\left(290,72 \mathrm{~kg} \mathrm{ha}^{-1}\right)$ de $\mathrm{CO}_{2}$ conferiu maior claridade à polpa no caso do cv. Jatte-Bintje.

Os valores da variável $\mathrm{a}^{*}$ dos tubérculos de batata sem tratamento com $\mathrm{CO}_{2}$ variaram entre $-3,32$ e -2,42 (Tabela 51). Estes valores indicam que este parâmetro de cor da polpa dos tubérculos, numa escala de $-60 \mathrm{a}+60$, se situa bem próximo de zero, com pequena tendência para o verde. 
Tabela 51. Valores médios do parâmetro $\mathrm{a}^{*}$ da polpa dos tubérculos dos cultivares de batata produzidos sob diferentes tratamentos (T1 - 0; T2 - 145,36; T3 - 290,72 $\mathrm{kg} \mathrm{ha}^{-1}$ de $\mathrm{CO}_{2}$ )

\begin{tabular}{|c|c|c|c|}
\hline \multirow{2}{*}{ Tratamento } & \multicolumn{3}{|c|}{ Valores médios de $a^{*}$ da polpa dos tubérculos } \\
\hline & Atlantic & Jatte-Bintje & Monalisa \\
\hline $\begin{array}{l}\text { T1 } \\
\text { T2 } \\
\text { T3 }\end{array}$ & $\begin{array}{l}-2,42 a \\
-2,57 a \\
-2,51 a\end{array}$ & $\begin{array}{l}-2,85 a \\
-3,01 a \\
-3,06 a\end{array}$ & $\begin{array}{l}-3,32 a \\
-3,17 a \\
-3,06 a\end{array}$ \\
\hline Médias & $-2,50 A$ & $-2,97 B$ & $-3,18 B$ \\
\hline
\end{tabular}

Médias seguidas por letras minúsculas iguais nas colunas e por letras maiúsculas nas linhas não diferem entre si pelo teste de Tukey em nível de $5 \%$

Sendo: $\mathrm{a}^{*}$ (escala de -60 verde $\mathrm{a}+60$ vermelho)

Comparando as médias dos cultivares de batata observa-se pela Tabela 51 que o cultivar Atlantic apresentou menores valores de verde que os demais cultivares, que não se diferenciaram significativamente entre si.

Comparado-se os valores de $\mathrm{a}^{*}$ dentro dos três cultivares de batata verifica-se que não foi observada diferença estatisticamente significativa entre a amostra não tratada e as tratadas com diferentes dosagens de $\mathrm{CO}_{2}$.

Os valores de $b^{*}$ (Tabela 52) dos tubérculos de batata sem tratamento com $\mathrm{CO}_{2}$ variaram entre $+16,26 \mathrm{e}+22,41$. Estes valores indicam que a polpa, numa escala de $-60 \mathrm{a}+60$, apresentou maior tendência para o amarelo, conforme esperado.

Comparando as médias dos cultivares de batata observa-se que os menores valores de $b^{*}$ (menor tonalidade amarela) foram apresentados pelo cultivar Monalisa e os maiores valores (maior intensidade de amarelo) para os cultivares Jatte-Bintje e Monalisa, que não diferiram significativamente entre si. 
Tabela 52. Valores médios do parâmetro $b^{*}$ da polpa dos tubérculos dos cultivares de batata produzidos sob diferentes tratamentos (T1 - 0; T2 - 145,36; T3 - 290,72 $\mathrm{kg} \mathrm{ha}^{-1}$ de $\mathrm{CO}_{2}$ )

\begin{tabular}{cccc}
\multicolumn{4}{c}{$\left(\mathrm{T} 1-0 ; \mathrm{T} 2-145,36 ; \mathrm{T} 3-290,72 \mathrm{~kg} \mathrm{ha}^{-1} \mathrm{de} \mathrm{CO}_{2}\right)$} \\
\hline \multirow{2}{*}{ Tratamento } & \multicolumn{3}{c}{ Valores médios de $\mathbf{b}^{*}$ da polpa dos tubérculos } \\
& Atlantic & Jatte-Bintje & Monalisa \\
\hline T1 & $16,26 \mathrm{a}$ & $21,17 \mathrm{~b}$ & $22,41 \mathrm{a}$ \\
T2 & $16,92 \mathrm{a}$ & $21,87 \mathrm{~b}$ & $22,80 \mathrm{a}$ \\
T3 & $17,12 \mathrm{a}$ & $22,60 \mathrm{a}$ & $21,94 \mathrm{a}$ \\
Médias & $\mathbf{1 6 , 7 7 B}$ & $\mathbf{2 1 , 8 8 \mathrm { A }}$ & $\mathbf{2 2 , 3 8 A}$
\end{tabular}

Médias seguidas por letras minúsculas iguais nas colunas e por letras maiúsculas nas linhas não diferem entre si pelo teste de Tukey em nível de $5 \%$

Sendo: b*(escala de -60 azul a +60 amarelo)

Os cultivares Atlantic e Monalisa não apresentaram alteração estatisticamente significativa para os valores de $b^{*}$ com os diferentes tratamentos. No entanto, o cultivar Jatte-Bintje apresentou maior intensidade de amarelo nos tubérculos produzidos com aplicação da maior dose de $\mathrm{CO}_{2}\left(290,72 \mathrm{~kg} \mathrm{ha}^{-1}\right)$. Neste cultivar, a menor média de $b^{*}$ foi registrado para a amostra sem aplicação de $\mathrm{CO}_{2}$, seguida da dose mais baixa de $\mathrm{CO}_{2}$, mas que não diferiram significativamente entre si.

\subsubsection{Matéria seca}

Os teores médios de matéria seca dos tubérculos de batata (Tabela 53) sem tratamento com $\mathrm{CO}_{2}$ variaram entre 18,35 e 21,90\%. O valor encontrado para o cv. Jatte-Bintje (19,4\%) é ligeiramente superior ao encontrado por Feltran (2002) para o cv. Bintje, que foi $17,9 \%$. Considerando o agrupamento sugerido por Cacace et al. (1994) o cultivar Atlantic pode ser classificado como sendo de alto conteúdo de matéria seca. Já os cultivares Jatte-Bintje e Monalisa são considerados como de conteúdo intermediário de matéria seca. 
Tabela 53. Teores médios de matéria seca (\%) dos tubérculos dos cultivares de batata produzidos por diferentes tratamentos (T1 - 0; T2 - 145,36; T3 $290,72 \mathrm{~kg} \mathrm{ha}^{-1} \mathrm{de} \mathrm{CO}_{2}$ )

\begin{tabular}{cccc}
\hline Tratamento & \multicolumn{2}{c}{ Teores médios de matéria seca dos tubérculos } \\
& Atlantic & Jatte-Bintje & Monalisa \\
\hline T1 & $21,90 \mathrm{a}$ & $19,35 \mathrm{a}$ & $18,35 \mathrm{ab}$ \\
T2 & $22,00 \mathrm{a}$ & $20,00 \mathrm{a}$ & $18,85 \mathrm{a}$ \\
T3 & $21,85 \mathrm{a}$ & $19,30 \mathrm{a}$ & $17,70 \mathrm{~b}$ \\
Médias & $\mathbf{2 1 , 9 2 A}$ & $\mathbf{1 9 , 5 5 \mathrm { B }}$ & $\mathbf{1 8 , 3 0 C}$ \\
\hline
\end{tabular}

Médias seguidas por letras minúsculas iguais nas colunas e por letras maiúsculas nas linhas não diferem entre si pelo teste de Tukey em nível de 5\%

A análise de variância para a variável matéria seca dos tubérculos indica que houve diferença significativa, pelo teste $F$, entre as médias dos cultivares de batata em nível de 5\%. Pela Tabela 53, os valores de matéria seca do cultivar Atlantic foram superiores, os do cv. Monalisa foram os menores teores e os do cv. Jatte-Bintje intermediários.

Dentro dos cultivares de batata, apenas no Monalisa observa-se variação significativa dos vabres de matéria seca dos tubérculos com os diferentes tratamentos. Obteve-se a maior média com a dose $2\left(145,36 \mathrm{~kg} \mathrm{ha}^{-1}\right.$ de $\left.\mathrm{CO}_{2}\right)$ e a menor média de matéria seca com a dose 3 (290,72 $\mathrm{kg} \mathrm{ha}^{-1}$ de $\left.\mathrm{CO}_{2}\right)$; entretanto, ambos não se diferenciaram significativamente da dose 1 (sem aplicação de $\left.\mathrm{CO}_{2}\right)$.

\subsubsection{Açúcares redutores}

Os teores médios de açúcares redutores (Tabela 54) dos tubérculos de batata sem tratamento com $\mathrm{CO}_{2}$ variaram entre 1,64 e 2,28\%. Estes valores são superiores aos encontrados por Paschalino et al. (1983) que foram de 1,1 $\pm 0,2 \mathrm{e}$ $1,1 \pm 0,3 \%$ (base seca) nos cultivares Bintje e Aracy, respectivamente. Já Feltran (2002), encontrou valores de 0,55; 0,51;0,32\% de açúcares redutores (base fresca) nos cultivares Aracy, Bintje, e Itararé, respectivamente. 
Tabela 54. Teor de açúcares redutores dos tubérculos dos cultivares de batata produzidos por diferentes tratamentos (T1 - 0; T2 - 145,36; $\mathrm{T} 3-290,72 \mathrm{~kg} \mathrm{ha}^{-1}$ de $\mathrm{CO}_{2}$ )

\begin{tabular}{cccc}
\hline Tratamento & \multicolumn{2}{l}{ Teor médio de açúcares redutores (\% base seca) } \\
& Atlantic & Jatte-Bintje & Monalisa \\
\hline T1 & $1,64 \mathrm{a}$ & $2,02 \mathrm{~b}$ & $2,28 \mathrm{a}$ \\
T2 & $1,55 \mathrm{a}$ & $2,64 \mathrm{a}$ & $2,20 \mathrm{a}$ \\
T3 & $1,89 \mathrm{a}$ & $2,18 \mathrm{~b}$ & $2,52 \mathrm{a}$ \\
Médias & $\mathbf{1 , 6 9 B}$ & $\mathbf{2 , 2 8 A}$ & $\mathbf{2 , 3 3 A}$ \\
\hline
\end{tabular}

Médias seguidas por letras minúsculas iguais nas colunas e por letras maiúsculas nas linhas não diferem entre si pelo teste de Tukey em nível de 5\%

Os cultivares Jatte-Bintje e Monalisa, segundo Pereira (1987), por apresentarem teor de açúcares redutores (base seca) acima de $2 \%$, seriam consideradas como inaceitáveis para processamento, enquanto que o cultivar Atlantic seria considerado como adequada para frituras por apresentar teor de açúcares redutores menor que $2 \%$.

A análise de variância para açúcares redutores dos tubérculos indica que houve diferença significativa, pelo teste $F$, entre as médias dos cultivares de batata em nível de $5 \%$. Comparando as médias dos cultivares observa-se que o cultivar Atlantic apresentou a menor média de açúcares redutores enquanto que os cultivares Monalisa e Jatte-Bintje apresentaram as maiores médias de açúcares redutores.

Entretanto, apenas para o cultivar Jatte-Bintje houve diferença significativa entre os tratamentos, sendo a maior média obtida para os tubérculos tratados com a dose $2\left(145,36 \mathrm{~kg} \mathrm{ha}^{-1}\right.$ de $\left.\mathrm{CO}_{2}\right)$ e as menores médias com as doses 1 e 3 , que não diferiram significativamente entre si. Donnelly et al. (2001c) não encontraram diferença significativa no conteúdo de açúcares totais no cv. Bintje com enriquecimento de $\mathrm{CO}_{2}$, reportaram entretanto aumento no conteúdo de glicose. 


\subsubsection{Amido}

Os teores médios de amido (Tabela 55) dos tubérculos de batata sem tratamento com $\mathrm{CO}_{2}$ variaram entre 66,79 e 75,40\%. O valor encontrado para o cultivar Jatte-Bintje é superior ao encontrado por Feltran (2002) para o cv. Bintje, que foi de $64,1 \%$ de amido (base seca). Esta diferença pode ser em parte, devido a metodologia utilizada.

Tabela 55. Teor de amido (\%) dos tubérculos dos cultivares de batata produzidos por diferentes tratamentos (T1 - 0; T2 - 145,36; T3 - 290,72 $\mathrm{kg} \mathrm{ha}^{-1}$ de $\mathrm{CO}_{2}$ )

\begin{tabular}{cccc}
\hline Tratamento & \multicolumn{2}{c}{$\begin{array}{c}\text { Teores médios de amido dos tubérculos (base seca) } \\
\text { Atlantic }\end{array}$} & $\begin{array}{c}\text { Jatte-Bintje } \\
\text { Monalisa }\end{array}$ \\
\hline T1 & $75,40 \mathrm{ab}$ & $71,21 \mathrm{ab}$ & $66,79 \mathrm{a}$ \\
T2 & $72,64 \mathrm{~b}$ & $71,55 \mathrm{a}$ & $70,93 \mathrm{a}$ \\
T3 & $77,20 \mathrm{a}$ & $66,94 \mathrm{~b}$ & $68,03 \mathrm{a}$ \\
Médias & $\mathbf{7 5 , 0 8 \mathrm { A }}$ & $\mathbf{6 9 , 9 0 \mathrm { B }}$ & $\mathbf{6 8 , 5 9 B}$ \\
\hline
\end{tabular}

Médias seguidas por letras minúsculas iguais nas colunas e por letras maiúsculas nas linhas não diferem entre si pelo teste de Tukey em nível de 5\%

A análise de variância para teor de amido presente nos tubérculos indica que houve diferença significativa, pelo teste $F$, entre as médias dos cultivares de batata em nível de 5\%. Verifica-se que o cultivar Atlantic apresentou os maiores teores de amido dentre os cultivares de batata estudados. Este cultivar também apresentou os menores teores de açúcares redutores. Os cultivares Jatte-Bintje e Monalisa apresentaram teores inferiores de amido e que não foram significativamente diferentes entre si.

O cultivar Monalisa não apresentou diferença significativa entre os tratamentos do experimento, já os cultivares Atlantic e Jatte-Bintje apresentaram diferença significativa, embora sem tendência definida. Assim, no cultivar Atlantic 
a dose 3 acarretou a maior média e a dose 2 a menor média de amido, que não diferenciaram-se significativamente da dose 1. Enquanto que no cultivar JatteBintje essa ordem foi invertida, apresentando a maior média com a dose 2 e a menor média com a dose 3, que também não foram significativamente diferentes da dose 1. Comparativamente Donnelly et al. (2001c) observaram incremento no conteúdo de amido com a dose de $399 \mu \mathrm{mol} \mathrm{mol}^{-1}$ de $\mathrm{CO}_{2}$ no cv. Bintje. Portanto, cada cultivar responde aos tratamentos de maneira diferente quanto a variação do teor de amido.

O aumento do teor de amido nos tubérculos pela elevação dos níveis de $\mathrm{CO}_{2}$ pode ser atribuído, segundo Donnelly et al. (2001a,b), à combinação do incremento de área foliar e dos níveis fotossintéticos instantâneos, aumentando dessa forma, a disponibilidade de assimilados e o armazenamento dos mesmos nos tubérculos. 


\section{CONCLUSÕES}

Considerando as condições em que foi conduzido o experimento, concluísse que:

- A concentração de $1.210 \mu \mathrm{mol}$ de $\mathrm{CO}_{2} \mathrm{~mol}^{-1}$ e $1.094,44 \mu \mathrm{mol}$ fótons $\mathrm{m}^{-2} \mathrm{~s}^{-1}$ de DFFFA acarretou maior incremento na fotossíntese do cultivar Itararé;

- O cultivar Itararé não apresentou variação de produtividade total com o aumento das doses de $\mathrm{CO}_{2}$;

- Mais de $50 \%$ da produção comercial do cultivar Itararé foi classificada como classe especial independente das doses de $\mathrm{CO}_{2}$;

- Os sólidos solúveis totais nos tubérculos do cultivar Itararé decresceram com o aumento das doses de $\mathrm{CO}_{2}$;

- A produtividade total de batata dos cultivares Atlantic, Jatte-Bintje e Monalisa diminuiu com doses crescentes de $\mathrm{CO}_{2}$;

- O cultivar Atlantic apresentou menor produtividade do que os cultivares Monalisa e Jatte-Bintje, respectivamente, independente das doses de $\mathrm{CO}_{2}$;

- O cultivar Atlantic apresentou maior percentagem de tubérculos de classe especial em relação aos cultivares Monalisa e Jatte-Bintje, respectivamente, independente da quantidade de $\mathrm{CO}_{2}$ aplicado;

- Houve efeitos das doses de $\mathrm{CO}_{2}$ sobre a firmeza dos tubérculos nos cultivares Atlantic e Monalisa; 
- Houve aumento de teor de açúcares no cultivar Jatte-Bintje com a aplicação de $\mathrm{CO}_{2}$;

- Os cultivares Atlantic e Jatte-Bintje apresentaram variação do teor de amido com a aplicação de $\mathrm{CO}_{2}$;

- Os valores de pH do solo sofreram um decréscimo temporário durante a aplicação de $\mathrm{CO}_{2}$ via água de irrigação. 


\section{REFERÊNCIAS BIBLIOGRÁFICAS}

ALTHOFF, D. A.; SILVA, A. C. F. da. O efeito da irrigação na cultura da batata no litoral sul catarinense, Agropecuária Catarinense, v.11, n.4, p.27-32, 1998.

ABRÉU, J. M. H.; LOPEZ, J. R. El riego localizado. In: CURSO INTERNACIONAL DE RIEGO LOCALIZADO, Madrid: 1987.317p.

ANGELOCCI, L.R. Aquisição do gás carbônico pelas plantas: mecanismos bioquímicos. Piracicaba: ESALQ, Depto. de Ciências Exatas, 2000.11p.

ARAÚJO, W.F. Aplicação de água carbonatada em abobrinha cultivada em solo com e sem cobertura plástica. Piracicaba, 2002. 86p. Tese (Doutorado) Escola Superior de Agricultura "Luiz de Queiroz", Universidade de São Paulo.

ARTECA, R.N.; POOVAIAH, B.W. Absorption of ${ }^{14} \mathrm{CO}_{2}$ by potato roots and its subsequent translocation. Journal of the American Society Horticultural Science, v.107, n.3, p.398-401, 1982a.

ARTECA, R.N.; POOVAIAH, B.W. Changes in phosphoenolpyruvate carboxylase and ribulose-1,5,-bisphosphate carboxylase in solanum tuberosum L. as affected by root zone applications of $\mathrm{CO}_{2}$. HortScience, v.17, n.3, p.396-398, $1982 b$. 
ARTECA, R. N.; POOVAIAH, B. W.; SMITH, O. E. Changes in carbon fixation, tuberization, and growth induced by $\mathrm{CO}_{2}$ applications to the root zone of potato plants. Science, v.205, n.21, p.1279-1280, 1979.

BAKER, R. Trichoderma spp. As plant-growth stimulants. Critical Reviews in Biotechnology, v.7, n.2, p.97-106, 1988.

BARON, J.J.; GORSKI, S.F. Resposta of eggplant to a root environment enriched with $\mathrm{CO}_{2}$. HortScience, v.21, n.3, p.495-498, 1986.

BAZZAZ, F.A.; JASIENSKI, M.; THOMAS, S.C.; WAYNE, P. Microevolutionary responses in experiental populations of plants to $\mathrm{CO}_{2}$-enriched environments: parallel results from two model systems. Proceedings National Academic Science, v.92, p.8161-8165, 1995.

BERNARDO, S. Manual de Irrigação. 5.ed. Viçosa: Biblioteca Central da Federal de Viçosa, 1989. 596p.

BERNARDO, S. Manual de Irrigação. 6.ed. Viçosa: Biblioteca Central da Federal de Viçosa, 1995. 657p.

BURTON, W.G. The potato. 3.ed. Singapore: Longman Scientific \& Technical, 1989. 742p.

BUTTERY, B.R.; BUZZELI, R.I. Some differences between soybean cultivars observed by growth analisis. Canadian Journal of Plant Science, v.52, n.1, p.13-20, 1972. 
CACACE, J.E.; HUARTE, M.A.; MONTI, M.C. Evaluation of potato cooking quality in Argentina. American Potato Journal, v.71, n.3, p.145-153, 1994.

CALDIZ, D.O. Genetic improvement and associated physiological changes en the potato. In: Genetic improvement of field crops. Slafer, G.A. (Ed.). New York: Marcel dekker, 1994. cap.4, p.361-411.

CALDIZ, D.O.; GASPARI, F.J. Análisis de los factores determinantes del rendimiento en papa (Solanum tuberosum) com especial referencia a la situación Argentina. Revista Facultad Agronomia, v.102, n.2, p.203-229, 1997.

CECCHI, H.M. Fundamentos teóricos e práticos em análise de alimentos. Campinas: Unicamp, 1999. 212p.

CLEGG, C.J.; WHITTINGHAM, C.P. Studies with inhibitors and exogenous substrates on dark $\mathrm{CO}_{2}$ fixation. Phytochemistry, v.11, n.9, p.2683-2691, 1972.

COKER, G.T.; SCHUBERT, K.R. Carbon dioxide fixation in soybean root and nodules. I. Characterization and comparation with N2 fixation and composition of xylem exudate during early nodule development. Plant Physiology, v.67, n.4/6, p.691-696, 1981.

COSTA, E. F. da; FRANÇA, G.E. de.; ALVES, V.M.C. Aplicação de fertilizantes via água de irrigação. Informe Agropecuário, v.12, n.139, p.63-68, 1986.

CRAMER, M.D.; OBERHOLZER, J.A.;COMBRINK, N.J.J. The effect of supplementation of root zone dissolved inorganic carbon on fruit yield and 
quality of tomatoes (cv Daniela) grown with salinity. Scientia Horticulturae, v.89, n.4, p.269-289, 2001.

CURE, J.D.; ACOCK, B. Crop responses to carbon dioxide doubling: a literature survey. Agricultural Forest and Meteorology, v.38, n.1/3, p.127-145, 1986.

CURTIS, P.S.; BALDUMAN, L.M.; DRAKE, B.G.; WHIGHAM, D.F. Elevated armospheric $\mathrm{CO}_{2}$ effects on belowground processes in $\mathrm{C} 3$ and $\mathrm{C} 4$ estuarine marsh communities. Ecology, v.71, n.5, p.2001-2006, 1990.

DIAS, C. A. C. Cultura da batata, Campinas: CATI, 1993. 33p. (Documento Técnico, 65).

DONNELLY, A.; CRAIGON, J.; BLACK, C.R.; COLLS, J.J.; LANDON, G. Does elevated $\mathrm{CO}_{2}$ ameliorate the impact of $\mathrm{O}_{3}$ on chlorophyll content and photosynthesis in potato (Solanum tuberosum L.). Physiologia Plantarum, v.111, n.4, p.501-511, 2001b.

DONNELLY, A.; CRAIGON, J.; BLACK, C.R.; COLLS, J.J.; LANDON, G. Elevated $\mathrm{CO}_{2}$ increases biomass and tuber yield in potato even at high $\mathrm{O}_{3}$ level. New Phytologist, v.149, n.2, p.265-274, 2001a.

DONNELLY, A.; LAWSON, T.; CRAIGON, J.; BLACK, C.R.; COLLS, J.J.; LANDON, G. Effects of elevated $\mathrm{CO} 2$ and $\mathrm{O} 3$ on tuber quality in potato (Solanum tuberosum L.). Agriculture, Ecosystems and Environment, v.87, n.3, p.273-285, 2001c. 
DOORENBOS, J.; PRUITT, W.O. Crop water requirement. Roma: FAO; 1977, 144p. (FAO: Irrigation and Drainage paper, 24).

DOORENBOS, J.; KASSAM, A.H. Yield response to water. Roma: FAO; 1979, 193p. (FAO: Irrigation and Drainage paper, 33).

DURÃO, P. L.; GALVÃO, A. C. Gás carbônico em irrigação. Ciência Hoje, v.19, n.110, p.12-15, 1995.

EMPRESA BRASILEIRA DE PESQUISA AGROPECUÁRIA - CENTRO NACIONAL DE PESQUISA DE HORTALIÇAS, Cultivo da Batata, Brasília: 1997a, 35p. (EMBRAPA - CNPH, Instruções Técnicas, 8).

EMPRESA BRASILEIRA DE PESQUISA AGROPECUÁRIA - CENTRO NACIONAL DE PESQUISA DE HORTALIÇAS, Manejo de água do solo no cultivo da batata, Brasília: 1997b, 35p. (EMBRAPA - CNPH, Comunicado Técnico, 3).

EPAMIG - EMPRESA DE PESQUISA AGROPECUÁRIA DE MINAS GERAIS, Batata - Produtividade com qualidade. Informe Agropecuário, v.20, n.197, 128p. 1999.

ESCOLA SUPERIOR DE AGRICULTURA "LUIZ DE QUIROZ". Departamento de Ciências Exatas. Base de dados. http://ce.esalq.usp.br/dce/postocon.htm (13 nov. 2002). 
EZETA, F.N.; McCOLLUM, R.E. Dry-matter production and nutrient uptake and removal by Solanum andigena in the Peruvian Andes. American Potato Journal, v.49, n.4, p.151-163, 1972.

FAO, Food, Agriculture Organisation of the United Nations, Production Yearbook, p.50-61, 1996.

FAQUHAR, G.D.; DUBLE, D.R.; RASCHKE, K. Gain of the feedback loop envolving carbon dioxide and stomat, theory and measurement. Plant Physiology, v.62, n.3, p.406-412, 1978.

FELTRAN, J. C. Determinação das características agronômicas, dos distúrbios fisiológicos, do estado nutricional da planta e da qualidade dos tubérculos em cultivares de batata (Solanum tuberosum L.). Botucatu, $2002.117 p$. Dissertação (Mestrado) - Faculdade de Ciências Agronômicas, Universidade Estadual Paulista “Júlio de Mesquita Filho".

FERRERES, E. Drip irrigation management. Berkeley: University of California, 1981. 39p.

FIELD, C.B.; CHAPIN III, F.S.; MATSON, P.A.; MOONEY, H.A. Responses of terrestrial ecosystems to the changing atmosphere: a resource-based approach. Annual Revolution Ecological Systems,. v.23, p.201-235, 1992.

FILGUEIRA, F. A. R. Manual de Olericultura, São Paulo: AGROCERES, 1982. v.2. $357 p$.

FILGUEIRA, F. A. R. Práticas culturais adequadas em bataticultura. Informe Agropecuário, v.20, n.197, p.34-41, 1999. 
FNP CONSULTORIA \& COMÉRCIO. AGRIANUAL 2000, Anuário estatístico da Agricultura Brasileira, São Paulo, 2000. p.201-212: Batata.

FNP CONSULTORIA \& COMÉRCIO. AGRIANUAL 2001, Anuário estatístico da Agricultura Brasileira, São Paulo, 2001. p.201-212: Batata.

FNP CONSULTORIA \& COMÉRCIO. AGRIANUAL 2002, Anuário estatístico da Agricultura Brasileira, São Paulo, 2002. p.190-201: Batata.

FURLAN, R.A.; ALVES, D.R.B.; FOLEGATTI, M.V. et al. Dioxido de carbono aplicado via água de irrigação na cultura da alface. Horticultura Brasileira, v.19, n.1, p.25-29, 2001.

GARANTINI, H.; BLANCO, H.B.; GALLO, J.R.; NÓBREGA, S. de A. Absorção de nutrientes pela batatinha, Bragantia, v.22, n.22, p.267-290, 1963.

GOMES, T.M. Efeito de CO2 aplicado na água de irrigação e no ambiente sobre a cultura da alface (Lactuca sativa L.). Piracicaba, 2001. 83p. Tese (Doutorado) - Escola Superior de Agricultura "Luiz de Queiroz", Universidade de São Paulo.

GOTO, R.; TIVELLI, S.W. Produção de Hortaliças, São Paulo: Editora UNESP, 1997. 319p.

GRIBBIN, J.The politics of carbon dioxide. New Science, v.90, p.82-84, 1981.

HAASE, N.U.; PLATE, J. Properties of potato starch in relation to varieties and environmental factors. Starch-Stärke, v.48, n.2, p.167-171, 1996. 
HAM, J. M.; OWENSBY, C. E.; COYNE, P.; BREMER, D. J. Fluxes of CO2 and water vapor from a prairie ecosystem exposed to ambiente and elevated atmospheric $\mathrm{CO}_{2}$, Agricultural Forest and Meteorology, v.77, n.1/2, p.7393, 1995.

HARMAN, J.; WATKINS, C. Use of the refactyometer to estimate the soluble solids in fresh fruit and vegetable. The Orchardist of New Zealand, v.54, n.1, p.3537, 1981.

HARTZ, T.K.; HOLT, D.B. Root-zone carbon dioxide enrichment in field does not improve tomato or cucumber yield. HortScience, v.26, n.11, p.1423, 1991.

HAWKINS, A. Rate of absortion and translocation of mineral nutrients by potatoes in Aroostook County, Maine, and their relation to fertilizer practices. Journal of the American Society of Agronomy, v.38, n.8, p.667-681, 1946.

IDSO, K. E.; IDSO, S. B. Plant responses to atmospheric $\mathrm{CO}_{2}$ enrichment in the face of environmental constraints: a review of the past 10 years' research. Agricultural Forest and Meteorology, v.69, n.3/4, p.153-203, 1994.

JACKSON, R.D.; HADDOCK, J.L. Growth and mineral uptake of Russet Burbank Potatoes. American Potato Journal, v.36, n.1, p.22-28, 1959.

JACKSON, W.A.;COLEMAN, N.T. Fixation of carbon dioxide by plant roots through phosphoenolpyruvate carboxylase. Plant and Soil, v.11, n.1, p.1-16, 1959.

KADAM, S.S.; DHUMAL, S.S.; JAMBHALE, N.D. Structure, nutritional composition, and quality. In: SALUNKHE, D.K.; KADAM, S.S.; JADHAV, S.J. 
Potato production, processing and products. Florida: CRC Press, 1991. p.9-35.

KARMELI, D.; KELLER, J. Evaluation of a Trickle irrigation System. In: INTERNATIONAL DRIP IRRIGATION CONGRESS, 2, 1974, Riverside. Proceedings..., Riverside, 1974. p.287-292.

KELLER, J.; KARMELI, D. Trickle irrigation design, Glendora, California: Rain Bird Sprinkler Manufacturing, 1975. 133p.

KIMBALL, B.A. Carbon dioxide and agricultural yield: na assemblage and analysis of 430 prior observations. Agronomy Journal. v.75, n.5, p.779-788, 1983.

KIMBALL, B. A.; LaMORTE, R. L.; SEAY, R. S. et al. Effects of free air $\mathrm{CO}_{2}$ enrichment on energy balance and evapotranspiration of cotton. Agricultural Forest and Meteorology, v.70, n.1/4, p.259-278, 1994.

KÖPPEN, W. Climatología: con un estudio de los climas de la tierra. México: Fondo de Cultura Económica, 1948. 478p.

LARCHER, W. Physiological plant ecology, 3.ed. Berlin: Springer - Verlag, 1995. 506p.

LEHNINGER, A.L. Princípios de bioquímica. São Paulo: Sarvier, 1988. 725p.

LINDHAUER, M.G.; DE FEKETE, M.A.R. Starch Synthesis in potato (Solanum tuberosum L.) tubers: activity of selectes enzimes in dependence of potassium content in storage tissue. Plant and soil, v.124, n.2, p.291-295, 1990. 
LINDROTH, R.L.; ROTH, S.; NORDHEIM, E.V. Genotypic variation in response of quaking aspen (Populus tremuloides) to atmospheric $\mathrm{CO}_{2}$ enrichment. Oecologia, v.126, n.3, p.371-379, 2001.

LONG, S.P.; HALLGREN, J.E. Measurement of $\mathrm{CO}_{2}$ assimilation by plants in the field and in the laboratory. In: HALL, D.O.; SCURLOCK, J.M.O.; BOLHAR NORDEN KAMPF, H.R.; LEEGOOD, R.C.; LONG, S.P. Photosynthesis and Laboratory Manual. London: Chapman \& Hall, 1993, p.129-167.

MAGALHÃES, J. R. Nutrição e adubação da batata, São Paulo: Nobel, 1985. $51 \mathrm{p}$.

MANABE, S.; WETHERALD, R. T. Thermal equilibrium of the atmosphere whit a given distribution of relative humidity. Journal Atmosfere Science, v.24, p.241-259, 1967.

MAROUELLI, W. A.; SILVA, W. L. de C.; SILVA, H. R. da. Manejo da irrigação em hortaliças. Brasília: EMBRAPA, Centro Nacional de Pesquisa de Hortaliças, 1994, 60p.

MAUNEY, J.R.; HENDRIX, D. L. Responses of glasshouse grown cotton to irrigation with carbon dioxide-saturated water. Crop Science, v.28, n.5, p.835838, 1988.

MELLO JUNIOR, A. V.; SOUZA, V. F. de.; DANTAS NETO, J. Considerações sobre métodos de aplicação de produtos químicos através de sistema de irrigação localizada. Engenharia Rural, v.3, n.2, p.79-91, 1992. 
MOORE, F.D. Potential for irrigation with carbon dioxide, Acta Horticulturae, n.278, v.1, p.171-178, 1990.

MORISON, J.I.L.; GIFFORD, R.M. Plant growth and water use with limited water supply in high $\mathrm{CO}_{2}$ concentrations. I.Leaf area, water use and transpiration. Australian Journal of Plant Physiology, v.11, n.5, p.361-374, 1984.

MORTENSEN, L.M. Review: $\mathrm{CO}_{2}$ enrichment in greenhouses crop responses, Scientia Horticulturae, v.33, n.1, p.1-25, 1987.

NAKAYAMA, F.S.; BUCKS, D.A. Using subsurface trickle system for carbon dioxide enrichment. In: JENSEN, M.H.; OEBKER, N.F. AGRICULTURE PLASTICS CONGRESS, 15, Proceedings, Manchester: National Agricultural Plastics Association, 1980. p.13-18.

NIVAA. On the road to processing. [on line]. 2003. http//www.nivaa.nl/index.html?pag=192 (05 maio 2003).

NOVERO, R.; SMITH, D.H.; MOORE, F.D. et al. Field grown tomato response to carbonated water application. Agronomy Journal, v.83, n.5, p.911-916, 1991.

OMETTO, J.C. Bioclimatologia vegetal. São Paulo: Agronômica Ceres, 1981. $440 p$.

PARRA, I. R. V. Fertilizantes solúveis e fertirrigação em algumas fruteiras do Chile. In: Folegatti, M.V.; Casarini, E.; Blanco, F.F.; Brasil, R.P.C do.; 
Resende, R.S. (Coord.) Fertirrigação. Piracicaba: Livraria e Editora Agropecuária, 2001. cap.5, p.163-200.

PASCHOALINO, J.E. Prevenção do escurecimento em batatas frescas descascadas e fatiadas. ITAL, v.23, n.2, p.189-197, 1993.

PAULA, M.B.; FONTES, P.C.R.; NOGUEIRA, F.D. Absorção de micronutrientes por cultivares de batata em presença e ausência de adubação. Horticultura Brasileira, v.4, n.2, p.3-8, 1986b.

PAULA, M.B.; FONTES, P.C.R.; NOGUEIRA, F.D. Produção de matéria seca e absorção de macronutrientes por cultivares de batata. Horticultura Brasileira, v.4, n.1, p.10-16, 1986a.

PEÑUELAS, J.; ESTIARTE, M. Can elevated $\mathrm{CO}_{2}$ affect secondary metabolism and ecosystem function. Trends Ecologic Evolution, v.13, p.20-24, 1998.

PEREIRA, A.S. Composição química, valor nutricional e industrialização. In: REIFSCHNEIDER, F.J.B. (Coord.) Produção de batata. Brasília: Linha gráfica, 1987. p.12-28.

PETERSON, R.L.; BARKER, W.R.; HOWARTH, M.J. Development and structure of tubers. In: LI, P.H. (Ed.). Potato Physiology. Orlando: Academic Press, 1985. p.123-152.

PINTO, J. M. Aplicações de dióxido de carbono via água de irrigação em meloeiro. Piracicaba, 1997, 82p Tese (Doutorado) - Escola Superior de Agricultura “Luiz de Queiroz”, Universidade de São Paulo. 
POTVIN, C.; VASSEUR, L. Long-term $\mathrm{CO}_{2}$ enrichment of a pasture community: species richness, dominance, and succession. Ecology, v.78, n.3, p.666-677, 1997.

RAMOS, A. Desenvolvimento vegetativo da pupunheira (Bastris gasipaes Kunth) irrigada por gotejamento em função de diferentes níveis de depleção de água no solo. Piracicaba, 1998. 66p. Dissertação (Mestrado) - Escola Superior de Agricultura "Luiz de Queiroz", Universidade de São Paulo.

RICKARD, J.E.; BEHN, K.R. Evaluation of acid and enzyme hydrolytic methods for the determination of cassava starch. Journal of Science, Food and Agriculture, v.41, n.4, p.373-379, 1987.

SAN JUAN, J. A. M. Riego por Goteo, 3. ed. Madrid: Mundi-Prensa, 1988. 256p.

SANCHES, O.F. Efecto del enriquecimiento del microambiente com $\mathrm{CO}_{2}$ en cultivo de melon em campo abierto. México: Liquid Carbonic de México. 1992, 7p.

SANTOS, M.M.F.B. Descrição de cultivares de batata, Brasília: Secretaria de Produção Agropecuária, Coordenadoria de Sementes e Mudas, 1986. 40p.

SAXE, H.; ELLSWORTH, D.S. HEATH, J. Tree and forest functioning in na enriched $\mathrm{CO}_{2}$ atmosphere. New Phytology, v.139, n.3, p.395-436, 1998.

SCHAPENDOK, A.H.C.M.; POT, C.S.; GOUDRIAAN, J. Simulated effects of elevated carbon dioxide concentration and temperature on the productivity of potato. Interaction with cultivar differences for earliness. In: Haverkort, D. 
Potato ecology and modelling of Crops under conditions limiting growth, Dordrecht: Klumer Academic, 1995. cap.2, p.101-114.

SHALLENBERGER, R.S.; SMITH, O.; TREADWAY, R.H. Role of the sugars in the browning reaction in potato chips. Journal of Agriculture and Food Chemistry, v.7, p.274-277, 1959.

SOMOGY, M. A new reagent for the determination of sugars. The Journal of Biological Chemistry, v.160, n.1, p.61-68, 1945.

STILING, P.; MOON, D.C.;HUNTER, M.D.;COLSON, J.; ROSSI A.M.; HYMUS, G.J.; DRAKE, B.G. Elevated $\mathrm{CO}_{2}$ lowers relative and absolute herbivore density across all species of a scrub-oak forest, Oecologia, v.134, n.1, p.8287, 2003.

STOLWIJK, J.A.; THIMANN, K.V. On the uptake of carbon dioxide and bicarbonate by roots and its influence on growth. Plant Physiology, v.32, n.6, p.513-519, 1957.

STOREY, R.M.J.; DAVIES, H.V. Tuber quality In: HARRIS, P. The potato crop. The scientific basis for improvement, London: Chapman and Hall, 1992. p.507-570.

STORLIE, C.A.; HECKMAN, J.R. Soil, plant, and canopy responses to carbonated irrigation water. Horticultural Technology, v.6, n.2, p.111-114, 1996.

TOGNONI, F.; HALEVY, A.H.; WITTWER. Growth of bean and tomato plants as affected by root absobed growth substances and atmospheric carbon dioxide. Planta, v.72, p.43-52, 1967. 
VESSEY, J. K.; HENRY, L. T.; RAPER JUNIOR, C. D. Nitrogen nutrition and temporal effects of enhanced carbon dioxide on Soybean growth. Crop Science, v.30, n.2, p.287-294, 1990.

WARD, J.K.; STRAIN, B.R. Elevated $\mathrm{CO}_{2}$ studies: past, present and future. Tree Physiology, v.19, p.211-220, 1999.

WITHERS, B.; VIPOND, S. Irrigação, São Paulo: EDUSP, 1977. 339p.

YORINORI,G.T. Curva de crescimento e acúmulo de nutrientes pela cultura de batata cv. 'Atlantic'. Piracicaba, 2003. 66p. Dissertação (Mestrado) - Escola Superior de Agricultura “Luiz de Queiroz”, Universidade de São Paulo.

ZANINI, J. R. Hidráulica de fertirrigação por gotejamento utilizando tanque de derivação de fluxo e bomba injetora. Piracicaba, 1987. 103p. Tese (Doutorando) - Escola Superior de Agricultura "Luiz de Queiroz", Universidade de São Paulo. 
ANEXOS 
Anexo A. Correlação entre massa fresca dos tubérculos (MFT), massa seca dos tubérculos (MST), número de folhas (NF), número de tubérculos (NT), massa seca da parte aérea (MSPA), e massa seca das raízes (MSR) do cv. Atlantic no experimento II

\begin{tabular}{|c|c|c|c|c|c|c|c|c|}
\hline & MFT & MST & $\mathrm{NF}$ & $\mathrm{AF}$ & $\mathrm{NE}$ & NT & MSPA & MSR \\
\hline MFT corr.Pearson & 1,000 & $0,977^{\star \star *}$ & 0,090 & $0,723^{\star \star}$ & $-0,257$ & $0,635^{\star \star *}$ & 0,295 & $0,650^{* x}$ \\
\hline Significância & & 0,000 & 0,674 & 0,000 & 0,226 & 0,001 & 0,162 & 0,001 \\
\hline $\mathrm{N}$ & 24 & 24 & 24 & 24 & 24 & 24 & 24 & 24 \\
\hline MST corr.Pearson & $0,977^{* \star}$ & 1,000 & 0,184 & $0,751^{\star *}$ & $-0,267$ & $0,636^{\star \star}$ & 0,308 & $0,652^{* \star}$ \\
\hline Significância & $\begin{array}{l}0,000 \\
24\end{array}$ & 24 & $\begin{array}{l}0,389 \\
24\end{array}$ & $\begin{array}{l}0,000 \\
24\end{array}$ & $\begin{array}{l}0,208 \\
24\end{array}$ & $\begin{array}{l}0,001 \\
24\end{array}$ & $\begin{array}{l}0,143 \\
24\end{array}$ & $\begin{array}{l}0,001 \\
24\end{array}$ \\
\hline $\begin{array}{cc}\text { NF } & \text { corr.Pearson } \\
& \text { Significância }\end{array}$ & $\begin{array}{l}0,90 \\
0,674\end{array}$ & $\begin{array}{l}0,184 \\
0,389\end{array}$ & 1,000 & $\begin{array}{l}0,563^{\star \star} \\
0,004\end{array}$ & $\begin{array}{l}-0,236 \\
0,267\end{array}$ & $\begin{array}{l}0,051 \\
0,813\end{array}$ & $\begin{array}{l}0,288 \\
0,172\end{array}$ & $\begin{array}{l}0,124 \\
0,564\end{array}$ \\
\hline $\mathrm{N}$ & 24 & 24 & 24 & 24 & 24 & 24 & 24 & 24 \\
\hline corr.Pearson & $0,723^{\star *}$ & $0,751^{\star \star}$ & $0,563^{\star \star}$ & 1,000 & $-0,218$ & 0,377 & $0,445^{\star}$ & $0,535^{\star \star}$ \\
\hline Significância & $\begin{array}{l}0,000 \\
24\end{array}$ & $\begin{array}{l}0,000 \\
24\end{array}$ & $\begin{array}{l}0,004 \\
24\end{array}$ & 24 & $\begin{array}{l}0,306 \\
24\end{array}$ & $\begin{array}{l}0,069 \\
24\end{array}$ & $\begin{array}{l}0,029 \\
24\end{array}$ & $\begin{array}{l}0,007 \\
24\end{array}$ \\
\hline NE corr.Pearson & $-0,257$ & $-0,267$ & $-0,236$ & $-0,218$ & 1,000 & $-0,188$ & 0,222 & $-0,122$ \\
\hline Significância & $\begin{array}{l}0,226 \\
24\end{array}$ & $\begin{array}{l}0,208 \\
24\end{array}$ & $\begin{array}{l}0,267 \\
24\end{array}$ & $\begin{array}{l}0,306 \\
24\end{array}$ & 24 & $\begin{array}{l}0,379 \\
24\end{array}$ & $\begin{array}{l}0,298 \\
24\end{array}$ & $\begin{array}{l}0,569 \\
24\end{array}$ \\
\hline $\begin{array}{cc}\text { NT } & \text { corr.Pearson } \\
& \text { Significância }\end{array}$ & $\begin{array}{l}0,635^{\star \star} \\
0,001\end{array}$ & $\begin{array}{l}0,636^{\star \star} \\
0,001\end{array}$ & $\begin{array}{l}0,051 \\
0,813\end{array}$ & $\begin{array}{l}0,377 \\
0,069\end{array}$ & $\begin{array}{l}-0,188 \\
0,379\end{array}$ & 1,000 & $\begin{array}{l}0,022 \\
0,920\end{array}$ & $\begin{array}{l}0,651^{* *} \\
0,001\end{array}$ \\
\hline $\mathrm{N}$ & 24 & 24 & 24 & 24 & 24 & 24 & 24 & 24 \\
\hline MSPA & & & & & & & & \\
\hline corr.Pearson & 0,295 & 0,308 & 0,288 & $0,445^{\star}$ & 0,222 & 0,022 & 1,000 & 0,266 \\
\hline Significância & 0,162 & 0,143 & 0,172 & 0,029 & 0,298 & 0,920 & & 0,210 \\
\hline $\mathrm{N}$ & 24 & 24 & 24 & 24 & 24 & 24 & 24 & 24 \\
\hline MSR corr.Pearson & $0,650^{\star \star}$ & $0,652^{\star \star}$ & 0,124 & $0,535^{\star *}$ & $-0,122$ & $0,651^{\star *}$ & 0,266 & 1,000 \\
\hline Significância & $\begin{array}{l}0,001 \\
24\end{array}$ & $\begin{array}{l}0,001 \\
24\end{array}$ & $\begin{array}{l}0,564 \\
24\end{array}$ & $\begin{array}{l}0,007 \\
24\end{array}$ & $\begin{array}{l}0,569 \\
24\end{array}$ & $\begin{array}{l}0,001 \\
24\end{array}$ & $\begin{array}{l}0,210 \\
24\end{array}$ & 24 \\
\hline
\end{tabular}


Gráfico de Normalidade

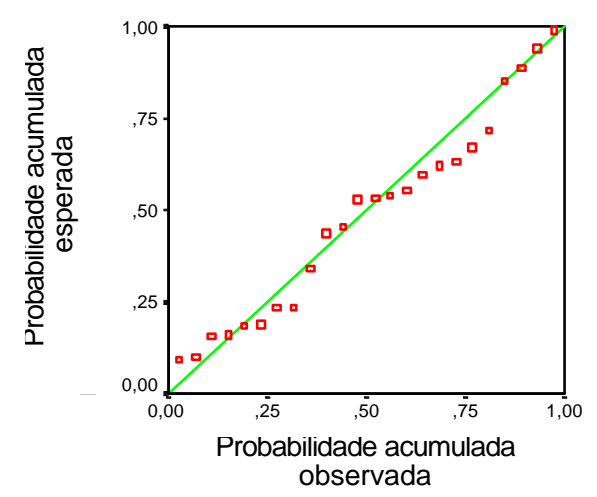

Gráfico de Dispersão

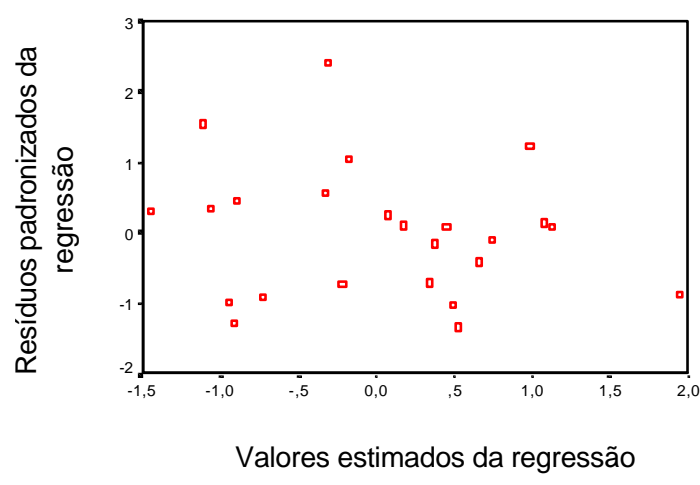

Anexo B. Análise de resíduos de massa fresca de tubérculos (MFT), massa seca de tubérculos (MST), número de folhas (NF), número de tubérculos (NT), massa seca da parte aérea (MSPA), e massa seca das raízes (MSR) do cv. Atlantic no experimento II 
Anexo C. Correlação entre massa fresca de tubérculos (MFT), massa seca de tubérculos (MST), número de folhas (NF), número de tubérculos (NT), massa seca da parte aérea (MSPA), e massa seca das raízes (MSR) do cv. Jatte-Bintje no experimento II

\begin{tabular}{|c|c|c|c|c|c|c|c|c|}
\hline & MFT & MST & $\mathrm{NF}$ & $\overline{A F}$ & $\mathrm{NE}$ & NT & MSPA & MSR \\
\hline $\begin{array}{l}\text { MFT corr.Pearson } \\
\text { Significância } \\
N\end{array}$ & $\begin{array}{l}1,000 \\
24\end{array}$ & $\begin{array}{l}0,931^{\star \star} \\
0,000 \\
24\end{array}$ & $\begin{array}{l}-0,257 \\
0,225 \\
24\end{array}$ & $\begin{array}{l}0,522^{\star \star} \\
0,009 \\
24\end{array}$ & $\begin{array}{l}0,121 \\
0,574 \\
24\end{array}$ & $\begin{array}{l}0,460^{*} \\
0,024 \\
24\end{array}$ & $\begin{array}{l}0,620^{\star \pi} \\
0,001 \\
24\end{array}$ & $\begin{array}{l}0,457^{*} \\
0,025 \\
24\end{array}$ \\
\hline MST corr.Pearson & $0,931^{\star \star}$ & 1,000 & $-0,046$ & $0,650^{* \star}$ & 0,179 & $0,457^{*}$ & $0,713^{* *}$ & $0,577^{* *}$ \\
\hline $\mathrm{N}_{\mathrm{N}}^{\text {Significância }}$ & $\begin{array}{l}0,000 \\
24\end{array}$ & 24 & $\begin{array}{l}0,830 \\
24\end{array}$ & $\begin{array}{l}0,001 \\
24\end{array}$ & $\begin{array}{l}0,402 \\
24\end{array}$ & $\begin{array}{l}0,025 \\
24\end{array}$ & $\begin{array}{l}0,000 \\
24\end{array}$ & $\begin{array}{l}0,003 \\
24\end{array}$ \\
\hline $\begin{array}{l}\text { NF corr.Pearson } \\
\text { Significância }\end{array}$ & $\begin{array}{l}-0,257 \\
0,225\end{array}$ & $\begin{array}{l}-0,046 \\
0,830\end{array}$ & 1,000 & $\begin{array}{l}0,420^{*} \\
0,041\end{array}$ & $\begin{array}{l}0,243 \\
0,252\end{array}$ & $\begin{array}{l}-0,048 \\
0,825\end{array}$ & $\begin{array}{l}0,441^{*} \\
0,031\end{array}$ & $\begin{array}{l}0,122 \\
0,571 \\
24\end{array}$ \\
\hline $\begin{array}{l}\text { AF corr.Pearson } \\
\text { Significância } \\
N\end{array}$ & $\begin{array}{l}24 \\
0,522^{\star \star} \\
0,009 \\
24\end{array}$ & $\begin{array}{l}24 \\
0,650^{\star \star} \\
0,001 \\
24\end{array}$ & $\begin{array}{l}24 \\
0,420^{*} \\
0,041 \\
24\end{array}$ & $\begin{array}{l}1,000 \\
24 \\
\end{array}$ & $\begin{array}{l}24 \\
0,475^{*} \\
0,019 \\
24 \\
\end{array}$ & $\begin{array}{l}0,009 \\
0,965 \\
24 \\
\end{array}$ & $\begin{array}{l}24 \\
0,869^{* \star} \\
0,000 \\
24\end{array}$ & $\begin{array}{l}24 \\
0,453^{*} \\
0,026 \\
24\end{array}$ \\
\hline $\begin{array}{ll}\text { NE corr.Pearson } \\
\text { Significância } \\
N\end{array}$ & $\begin{array}{l}0,121 \\
0,574 \\
24\end{array}$ & $\begin{array}{l}0,179 \\
0,402 \\
24\end{array}$ & $\begin{array}{l}0,243 \\
0,252 \\
24\end{array}$ & $\begin{array}{l}0,475^{*} \\
0,019 \\
24\end{array}$ & 1,000 & $\begin{array}{l}-0,156 \\
0,466 \\
24\end{array}$ & $\begin{array}{l}0,374 \\
0,072 \\
24\end{array}$ & $\begin{array}{l}0,546^{* \star} \\
0,006 \\
24\end{array}$ \\
\hline $\begin{array}{ll}\text { NT } & \text { corr.Pearson } \\
\text { Significância } \\
N\end{array}$ & $\begin{array}{l}0,460^{*} \\
0,024 \\
24\end{array}$ & $\begin{array}{l}0,457^{*} \\
0,025 \\
24\end{array}$ & $\begin{array}{l}-0,048 \\
0,825 \\
24\end{array}$ & $\begin{array}{l}0,009 \\
0,965 \\
24\end{array}$ & $\begin{array}{l}-0,156 \\
0,466 \\
24\end{array}$ & 1,000 & $\begin{array}{l}0,140 \\
0,513 \\
24\end{array}$ & $\begin{array}{l}0,419^{*} \\
0,042 \\
24\end{array}$ \\
\hline $\begin{array}{l}\text { MSPA } \\
\text { corr.Pearson } \\
\text { Significância }\end{array}$ & $\begin{array}{l}0,620^{\star *} \\
0,001 \\
24\end{array}$ & $\begin{array}{l}0,713^{\star *} \\
0,000 \\
24\end{array}$ & $\begin{array}{l}0,441^{*} \\
0,031 \\
24\end{array}$ & $\begin{array}{l}0,869^{\star *} \\
0,000 \\
24\end{array}$ & $\begin{array}{l}0,374 \\
0,072 \\
24\end{array}$ & $\begin{array}{l}0,140 \\
0,513 \\
24\end{array}$ & 1,000 & $\begin{array}{l}0,297 \\
0,158 \\
24\end{array}$ \\
\hline $\begin{array}{c}\text { MSR corr.Pearson } \\
\text { Significância } \\
N\end{array}$ & $\begin{array}{l}0,457^{*} \\
0,025 \\
24\end{array}$ & $\begin{array}{l}0,577^{\star \star} \\
0,003 \\
24\end{array}$ & $\begin{array}{l}0,122 \\
0,571 \\
24\end{array}$ & $\begin{array}{l}0,453^{*} \\
0,026 \\
24\end{array}$ & $\begin{array}{l}0,546^{\star \star} \\
0,006 \\
24\end{array}$ & $\begin{array}{l}0,419^{*} \\
0,042 \\
24\end{array}$ & $\begin{array}{l}0,297 \\
0,158 \\
24\end{array}$ & 1,000 \\
\hline
\end{tabular}


Gráfico de Normalidade

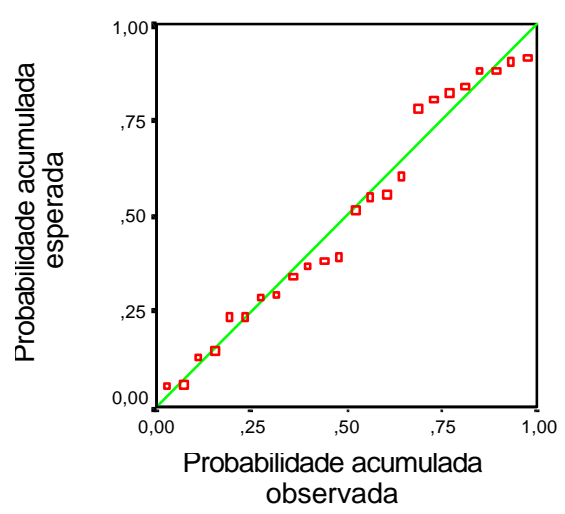

Gráfico de Dispersão

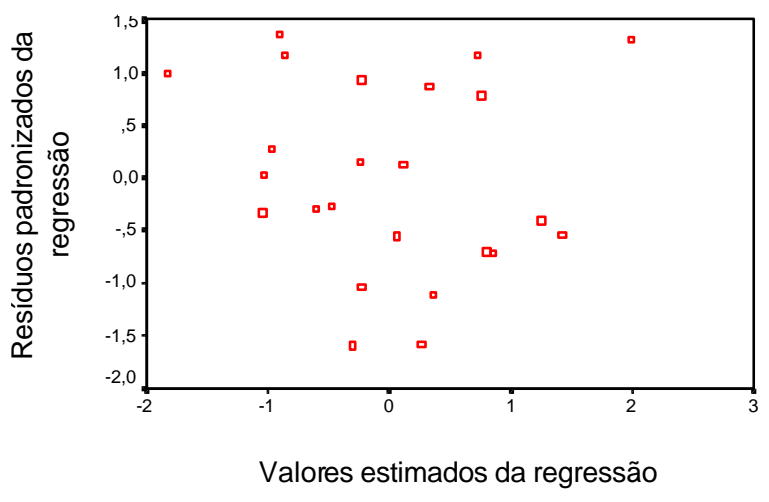

Anexo D. Análise de resíduos de massa fresca de tubérculos (MFT), massa seca de tubérculos (MST), número de folhas (NF), número de tubérculos (NT), massa seca da parte aérea (MSPA), e massa seca das raízes (MSR) do cv. Jatte-Bintje no experimento II 
Anexo E. Correlação entre massa fresca de tubérculos (MFT), massa seca de tubérculos (MST), número de folhas (NF), número de tubérculos (NT), massa seca da parte aérea (MSPA), e massa seca das raízes (MSR) do cv. Monalisa no experimento II

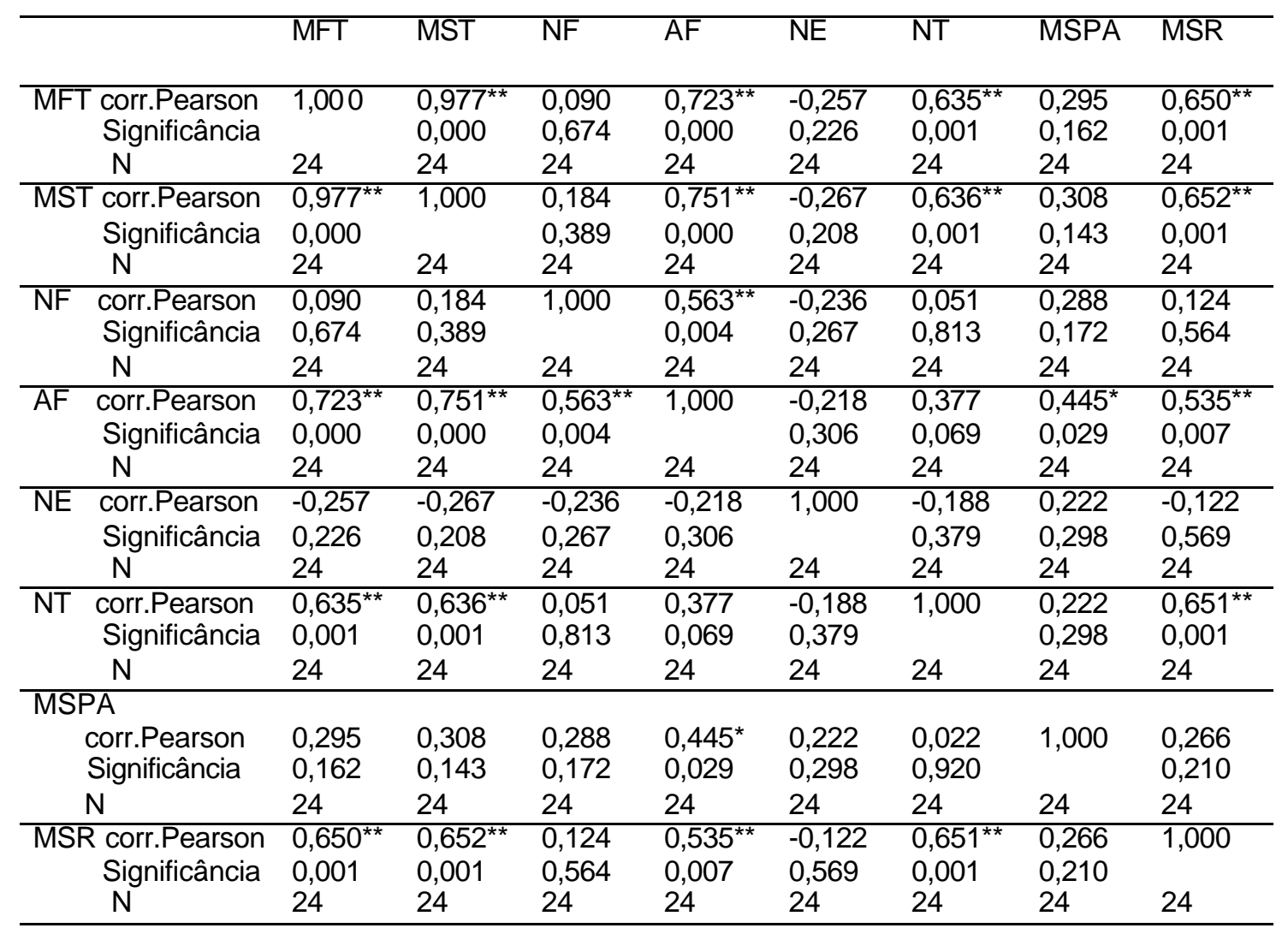



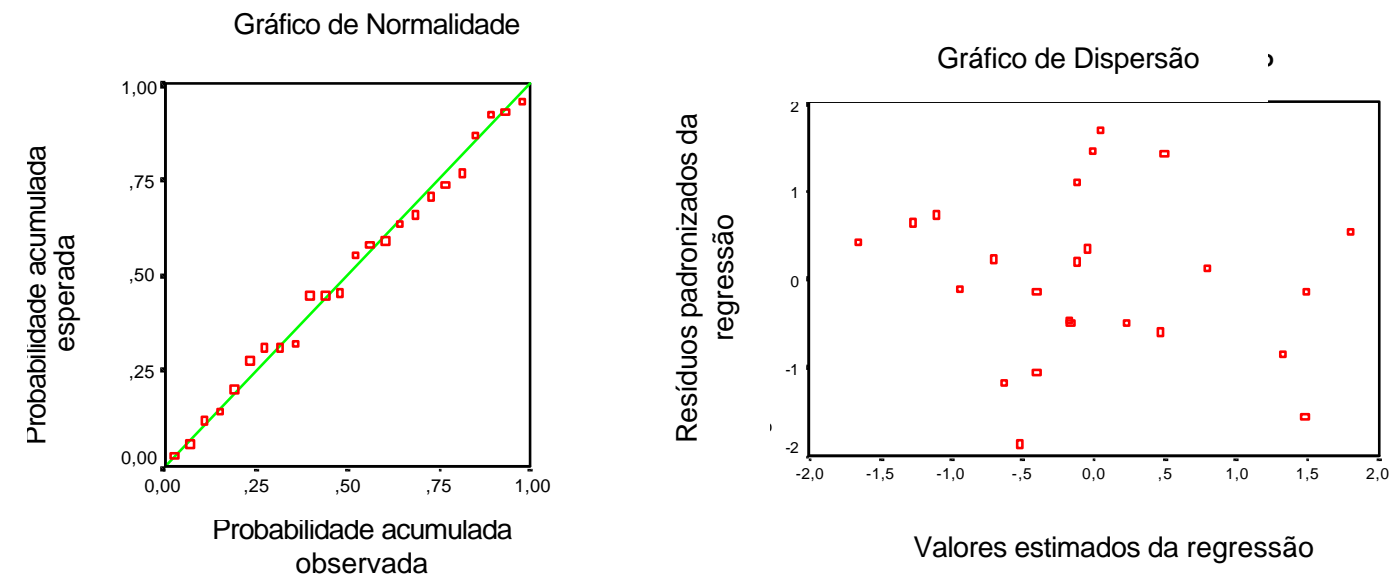

Anexo F. Análise de resíduos de massa fresca de tubérculos (MFT), massa seca de tubérculos (MST), número de folhas (NF), número de tubérculos (NT), massa seca da parte aérea (MSPA), e massa seca das raízes (MSR) do cv. Monalisa no experimento II 
Anexo G. Teste de homogeneidade no cultivar Atlantic

\begin{tabular}{cccc}
\hline $\begin{array}{c}\text { Estatística de } \\
\text { Levene }\end{array}$ & $\begin{array}{c}\text { Grau de liberdade } \\
1\end{array}$ & $\begin{array}{c}\text { Grau de liberdade } \\
2\end{array}$ & $\alpha$ \\
\hline 0,109 & 2 & 9 & 0,898 \\
\hline
\end{tabular}
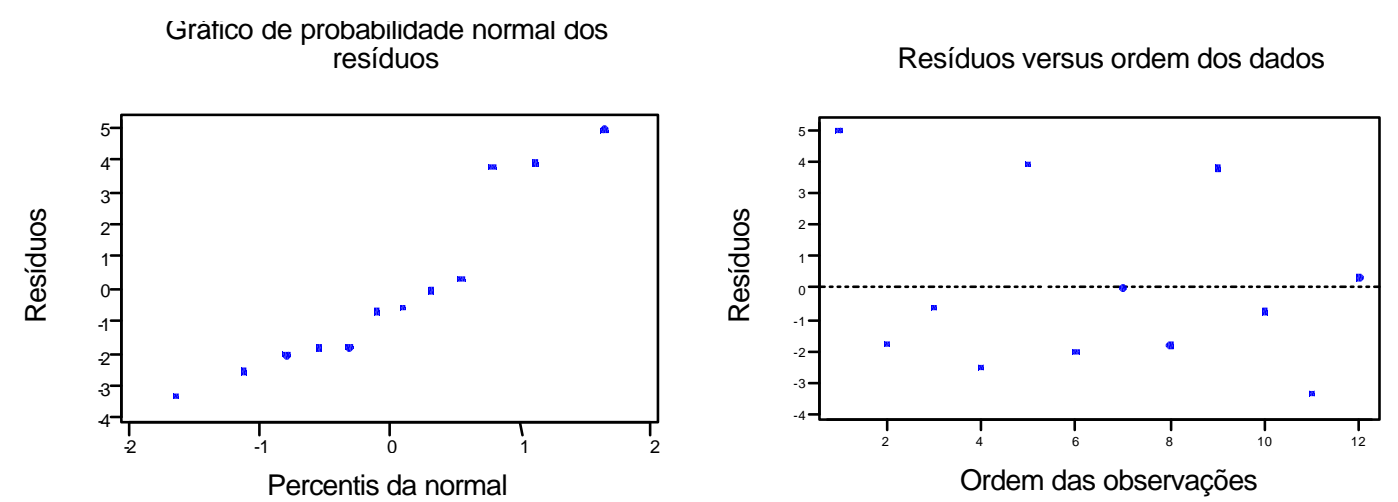

Anexo H. Análises de resíduos padronizados da produtividade em função às doses de $\mathrm{CO}_{2}$ no cultivar Atlantic 
Anexo I Teste de homogeneidade no cultivar Jatte-Bintje

\begin{tabular}{cccc}
\hline $\begin{array}{c}\text { Estatística de } \\
\text { Levene }\end{array}$ & $\begin{array}{c}\text { Grau de liberdade } \\
1\end{array}$ & $\begin{array}{c}\text { Grau de liberdade } \\
2\end{array}$ & $\alpha$ \\
\hline 4,182 & 2 & 9 & 0,052 \\
\hline
\end{tabular}

Grático de probabilidade normal dos

resíduos

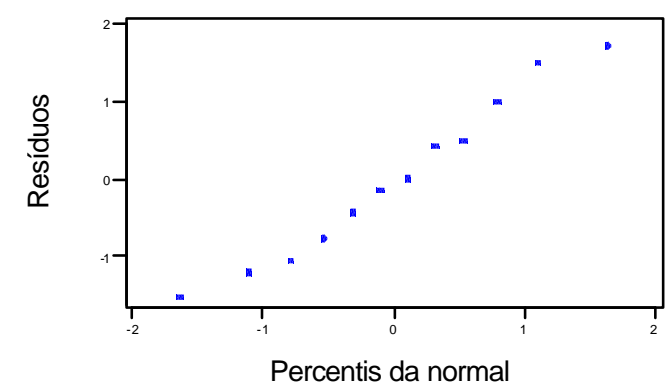

Resíduos versus ordem dos dados

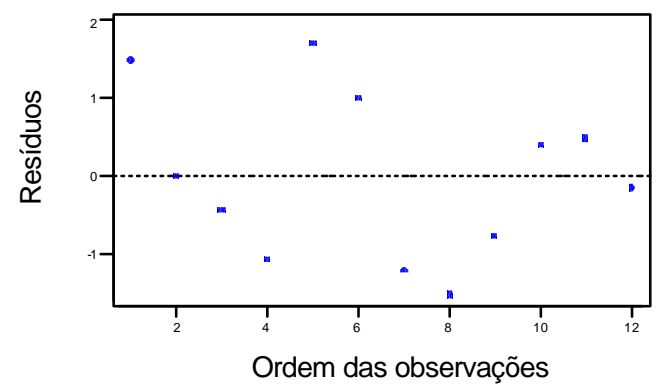

Anexo J. Análises de resíduos padronizados da produtividade em função às doses de $\mathrm{CO}_{2}$ no cultivar Jatte-Bintje 
Anexo K. Teste de homogeneidade no cultivar Monalisa

\begin{tabular}{cccc}
\hline $\begin{array}{c}\text { Estatística de } \\
\text { Levene }\end{array}$ & $\begin{array}{c}\text { Grau de liberdade } \\
1\end{array}$ & $\begin{array}{c}\text { Grau de liberdade } \\
2\end{array}$ & $\alpha$ \\
\hline 0,178 & 2 & 9 & 0,840 \\
\hline
\end{tabular}

Grático de probabilidade normal dos resíduos

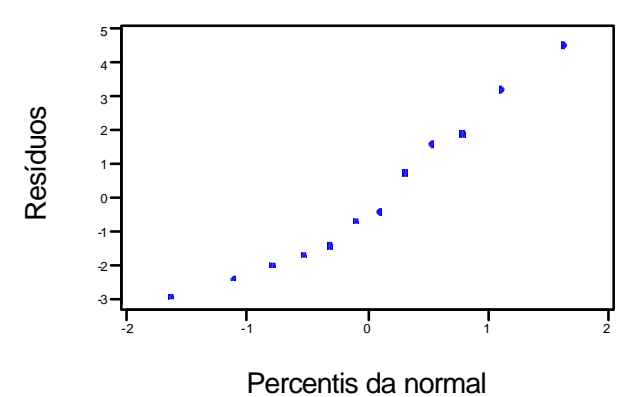

Resíduos versus ordem dos dados

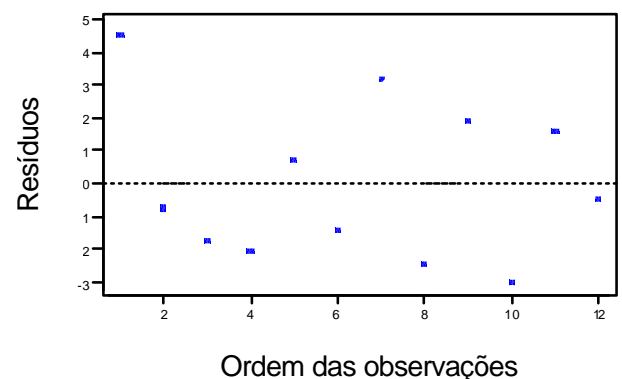

Ordem das observações

Anexo L. Análises de resíduos padronizados da produtividade em função às doses de $\mathrm{CO}_{2}$ no cultivar Monalisa 